Nevada

Environmental

Restoration

Project

\title{
Corrective Action Investigation Plan for Corrective Action Unit 543: Liquid Disposal Units \\ Nevada Test Site, Nevada
}

Controlled Copy No::

Revision No.: 0

May 2004

Approved for public release; further dissemination unlimited.

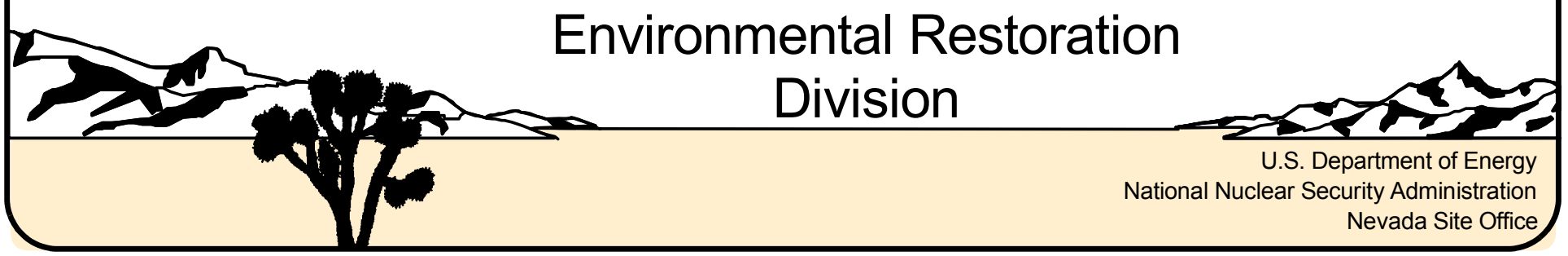


Available for public sale, in paper, from:

U.S. Department of Commerce

National Technical Information Service

5285 Port Royal Road

Springfield, VA 22161

Phone: 800.553 .6847

Fax: 703.605.6900

Email: orders@ntis.gov

Online ordering: http://www.ntis.gov/ordering.htm

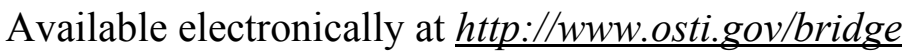

Available for a processing fee to U.S. Department of Energy and its contractors, in paper, from:

\section{U.S. Department of Energy}

Office of Scientific and Technical Information

P.O. Box 62

Oak Ridge, TN 37831-0062

Phone: 865.576 .8401

Fax: 865.576.5728

Email: reports@adonis.osti.gov

Reference herein to any specific commercial product, process, or service by trade name, trademark, manufacturer, or otherwise, does not necessarily constitute or imply its endorsement, recommendation, or favoring by the United States Government or any agency thereof or its contractors or subcontractors. 


\title{
CORRECTIVE ACTION INVESTIGATION PLAN FOR CORRECTIVE ACTION UNIT 543: LIQUID DISPOSAL UNITS NEVADA TEST SITE, NEVADA
}

\author{
U.S. Department of Energy \\ National Nuclear Security Administration \\ Nevada Site Office \\ Las Vegas, Nevada
}

Controlled Copy No.:

Revision No.: 0

May 2004

Approved for public release; further dissemination unlimited. 


\section{CORRECTIVE ACTION INVESTIGATION PLAN \\ FOR CORRECTIVE ACTION UNIT 543 \\ LIQUID DISPOSAL UNITS \\ NEVADA TEST SITE, NEVADA}

Approved by: Signature Approved

Date: $4-29-04$

Kevin Cabble, Acting Project Manager

Industrial Sites Project

Approved by: Signature Approved

Date: $4 / 28 / 04$

Janet Appenzeller-Wing, Acting Division Director

Environmental Restoration Division 


\section{Table of Contents}

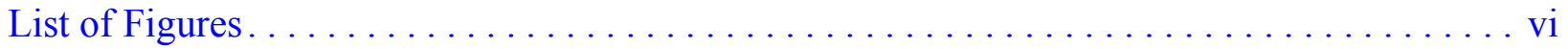

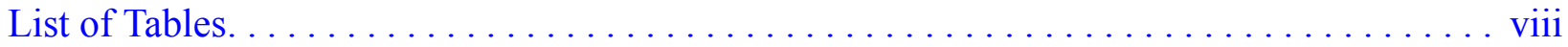

List of Acronyms and Abbreviations $\ldots \ldots \ldots \ldots \ldots \ldots \ldots \ldots \ldots \ldots \ldots \ldots \ldots \ldots$

Executive Summary . . . . . . . . . . . . . . . . . . . . . . . . . . . ES-1

$1.0 \quad$ Introduction. . . . . . . . . . . . . . . . . . . . . . . . . .

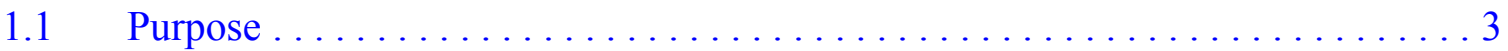

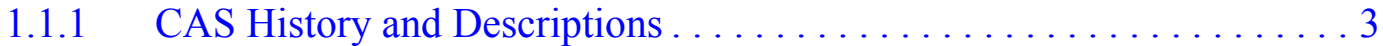

1.1.1.1 Area 6 Decontamination Facility ............. 3

1.1.1.2 Area 15, EPA Farm ..................4

1.1.2 Data Quality Objectives Summary...................6 6

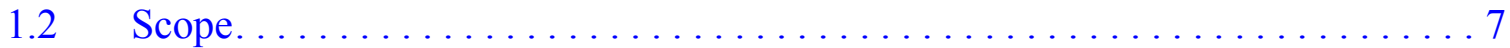

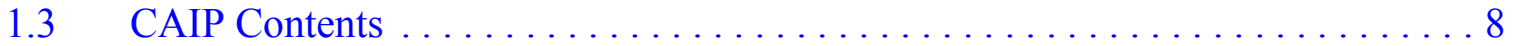

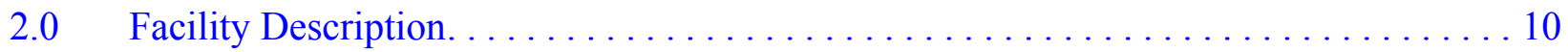

$2.1 \quad$ Physical Setting. . . . . . . . . . . . . . . . . . . 10

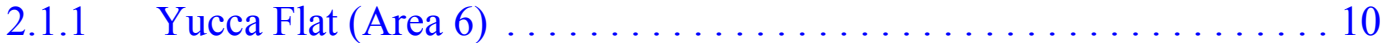

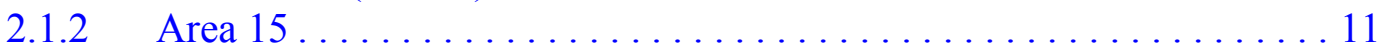

2.2 Operational History. . . . . . . . . . . . . . . . . . . . 12

2.2.1 Area 6 Decontamination Facility . . . . . . . . . . . . . . . . . 12

2.2.1.1 CAS 06-07-01, Decon Pad ................. 14

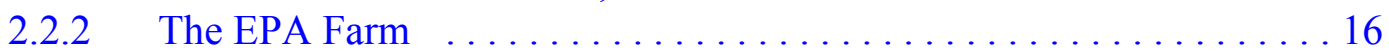

2.2.2.1 CAS 15-04-01, Septic Tank . . . . . . . . . . . 19

2.2.2.2 CAS 15-05-01, Leachfield ................ 19

2.2.2.3 CAS 15-08-01, Liquid Manure Tank . . . . . . . . . . 20

2.2.2.4 CAS 15-23-03, Contaminated Sump, Piping . . . . . . . 20

2.2.2.5 CAS 15-01-03, Aboveground Storage Tank ......... 21

2.2.2.6 CAS 15-23-01, Underground Radioactive Material Area . 21

2.3 Waste Inventory . . . . . . . . . . . . . . . . . . 22

2.3.1 CAS 06-07-01, Decon Pad ...................... 22

$2.3 .2 \quad$ EPA Farm . . . . . . . . . . . . . . . . . . . . . 23

2.4 Release Information . . . . . . . . . . . . . . . . . . . . . 24

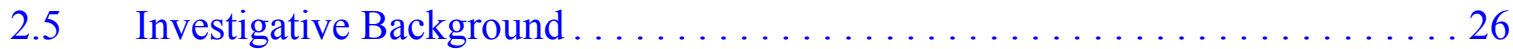

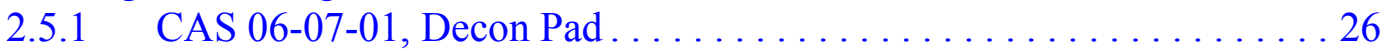

2.5.2 CAS 15-04-01, Septic Tank ....................... 26

2.5.3 CAS 15-05-01, Leachfield . . . . . . . . . . . . . . . . . . . 27

2.5.4 CAS 15-08-01, Liquid Manure Tank . . . . . . . . . . . . . . . 28

2.5.5 CAS 15-23-03, Contaminated Sump, Piping . . . . . . . . . . . . . 28

2.5.6 CAS 15-01-03, Aboveground Storage Tank . . . . . . . . . . . . . 28

2.5.7 CAS 15-23-01, Underground Radioactive Materials Area . . . . . . . . 28 


\section{Table of Contents (Continued)}

$2.6 \quad$ National Environmental Policy Act . . . . . . . . . . . . . . . . . . . . . 29

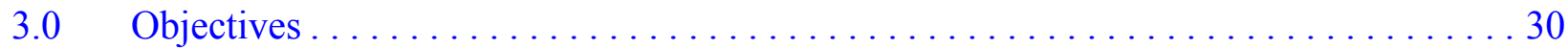

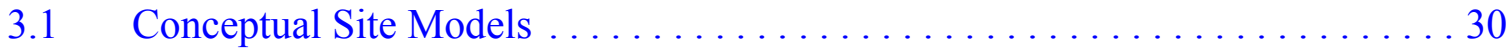

3.1.1 Future Land Use . . . . . . . . . . . . . . . . . . . . 31

3.1.2 Contaminant Sources . . . . . . . . . . . . . . . . . . . . 32

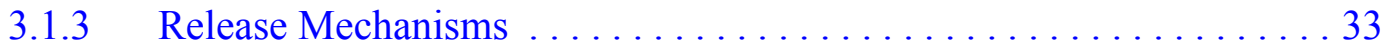

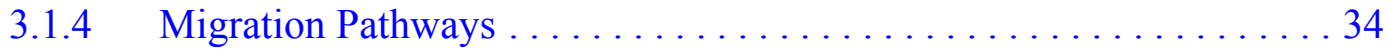

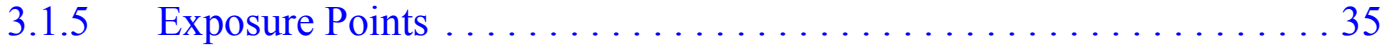

3.1.6 Exposure Routes............................. 35

3.1 .7 Additional Information. . . . . . . . . . . . . . . . . . . . 35

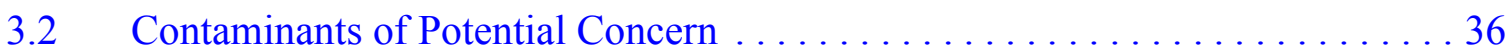

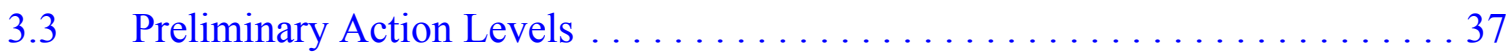

3.3.1 Field-Screening Levels. . . . . . . . . . . . . . . . . . . . 39

3.4 Data Quality Objectives Process Discussion . . . . . . . . . . . . . . . . . . . 39

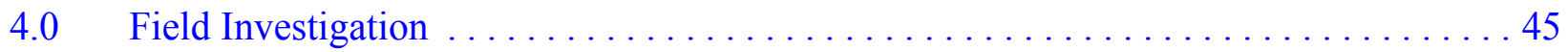

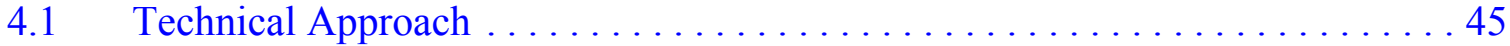

$4.2 \quad$ Field Activities . . . . . . . . . . . . . . . . . . . . . 46

4.2.1 Site Preparation Activities . . . . . . . . . . . . . . . . 47

4.2 .2 Decision I Activities. . . . . . . . . . . . . . . . . . . . . 47

4.2 .3 Decision II Activities . . . . . . . . . . . . . . . . . . . . . . . . . 49

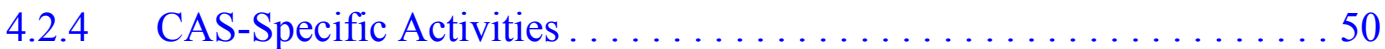

4.2.4.1 CAS 06-07-01, Decon Pad .............. 50

4.2.4.2 Area 15 EPA Farm .................. 54

4.3 Geotechnical/Hydrological Analysis and Bioassessment Tests . . . . . . . . . 64

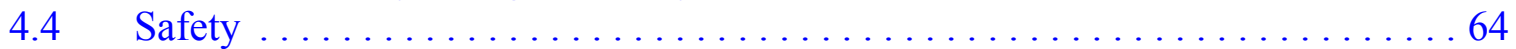

$5.0 \quad$ Waste Management. . . . . . . . . . . . . . . . . . 66

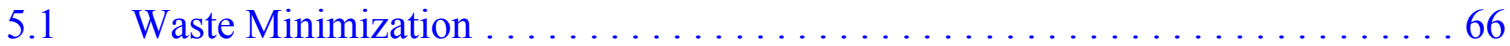

5.2 Potential Waste Streams . . . . . . . . . . . . . . . . . . . . . 66

5.3 Investigation-Derived Waste Management $\ldots \ldots \ldots \ldots \ldots \ldots \ldots \ldots$

$5.3 .1 \quad$ Sanitary Waste . . . . . . . . . . . . . . . . . . . 67

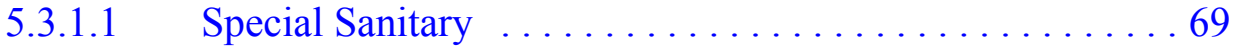

5.3.2 Hazardous Waste . . . . . . . . . . . . . . . . . . . . . . . 69

5.3.2.1 Management of Personal Protective Equipment ..... . 70

5.3.2.2 Management of Decontamination Rinsate . . . . . . . . . 70

5.3.2.3 Management of Soil . . . . . . . . . . . . . 71

5.3.2.4 Management of Debris . . . . . . . . . . . . . 71

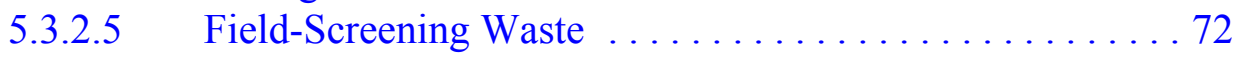

5.3 .3 Polychlorinated Biphenyls . . . . . . . . . . . . . 72 


\section{Table of Contents (Continued)}

$5.3 .4 \quad$ Low-Level Waste. . . . . . . . . . . . . . . . . . . . . . 72

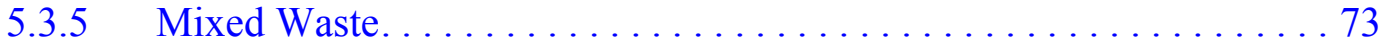

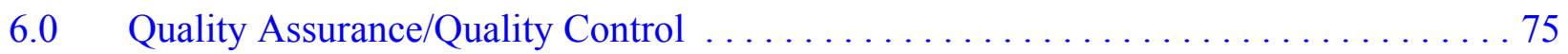

6.1 Quality Control Field Sampling Activities . . . . . . . . . . . . . . 75

6.2 Laboratory and Analytical Quality Assurance .................. 76

$6.2 .1 \quad$ Data Validation. ............................ 76

6.2 .2 Data Quality Indicators. . . . . . . . . . . . . . . . 76

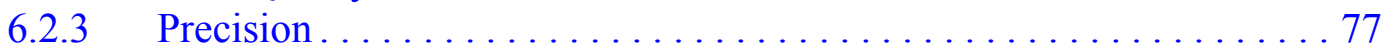

6.2.3.1 Precision for Chemical Analysis . . . . . . . . . . . 79

6.2.3.2 Precision for Radiological Analysis . . . . . . . . . . . . 79

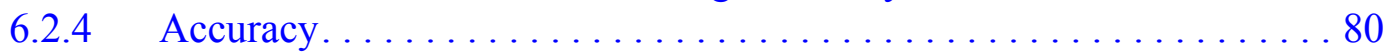

6.2.4.1 Accuracy for Chemical Analyses . . . . . . . . . . 8 80

6.2.4.2 Accuracy for Radiological Analysis . . . . . . . . . . 8 81

6.2.5 Representativeness . . . . . . . . . . . . . . . . . . . . . . 81

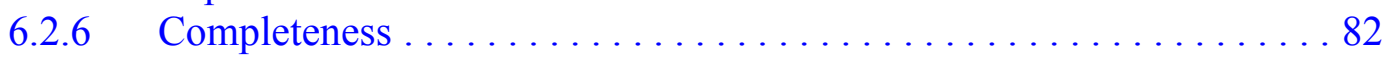

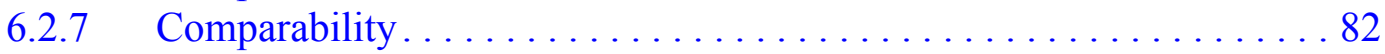

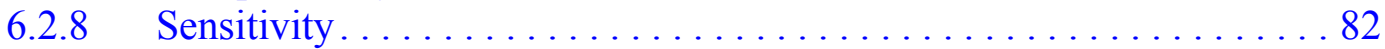

6.3 Radiological Survey Quality Assurance .................. 83

$7.0 \quad$ Duration and Records Availability . . . . . . . . . . . . . . . . . 84

$7.1 \quad$ Duration . . . . . . . . . . . . . . . . . . . . . . . . . 84

$7.2 \quad$ Records Availability ............................ 84

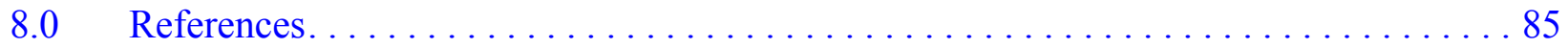

Appendix A.1 - Data Quality Objectives ......................... A-1

A.1 Data Quality Objectives Process. . . . . . . . . . . . . . . . . . . . A-2

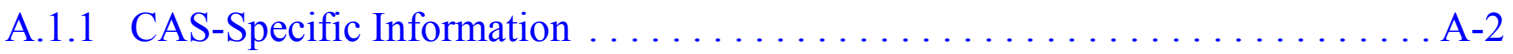

A.1.1.1 Area 6 Decontamination Facility . . . . . . . . . . . . . . A-4

A.1.1.1.1 CAS 06-07-01, Decon Pad .................. A-9

A.1.1.2 U.S. Environmental Protection Agency Farm . . . . . . . . . . . . . A-13

A.1.1.3 CAS 15-04-01, Septic Tank .................... A-17

A.1.1.4 CAS 15-05-01, Leachfield . . . . . . . . . . . . . . . A-18

A.1.1.5 CAS 15-08-01, Liquid Manure Tank . . . . . . . . . . . . . . . . . . . A-19

A.1.1.6 CAS 15-23-03, Contaminated Sump, Piping . . . . . . . . . . . . A-20

A.1.1.7 CAS 15-01-03, Aboveground Storage Tank . . . . . . . . . . . . A A-22

A.1.1.8 CAS 15-23-01, Underground Radioactive Material Area . . . . . . . A A-23

A.1.2 Seven-Step DQO Process . . . . . . . . . . . . . . . . . . . A-24

A.1.2.1 Step 1 - State the Problem .................... A-24 


\section{Table of Contents (Continued)}

A.1.2.2 Planning Team Members ........................ A-24

A.1.2.3 Describe the Problem ............................ A-24

A.1.2.4 Develop Conceptual Site Models.................... A-25

A.1.2.5 Conceptual Site Model for Area 6, Decontamination Processes . . . . A-26

A.1.2.6 Conceptual Site Model for Area 15, EPA Farm Processes . . . . . . . A-29

A.1.3 Step 2 - Identify the Decision . . . . . . . . . . . . . . . . . . . . A-32

A.1.3.1 Develop a Decision Statement .................. A-32

A.1.3.2 Alternative Actions to the Decision ................ A-33

A.1.4 Step 3 - Identify the Inputs to the Decision . ................. A-33

A.1.4.1 Information Needs and Information Sources ............... A-33

A.1.4.2 Determine the Basis for the Preliminary Action Levels. . . . . . . . . A-36

A.1.4.3 Potential Sampling Techniques and Appropriate

Analytical Methods .......................... A-37

A.1.4.3.1 Field Screening ....................... A-38

A.1.4.3.2 Soil Sampling ..................... A-38

A.1.4.3.3 Radiological Walk-Overs and Scanning/

Swipe Sampling ........................ A-39

A.1.4.3.4 Video Survey $\ldots \ldots \ldots \ldots \ldots \ldots \ldots \ldots \ldots$. A-39

A.1.4.3.5 Concrete Sampling . . . . . . . . . . . . . . . . . . A-39

A.1.4.3.6 Analytical Program ..................... A-40

A.1.5 Step 4 - Define the Boundaries of the Study . ................. A-43

A.1.5.1 Define the Target Population ...................... A-43

A.1.5.2 Identify the Spatial and Temporal Boundaries. . . . . . . . . . . A-43

A.1.5.3 Identify Practical Constraints . . . . . . . . . . . . . . . A-43

A.1.5.4 Define the Scale of Decision Making. . . . . . . . . . . . . . A-45

A.1.6 Step 5 - Develop a Decision Rule.......................... A-45

A.1.6.1 Specify the Population Parameter .................. A-45

A.1.6.2 Choose an Action Level . . . . . . . . . . . . . . . . . . . A-45

A.1.6.3 Decision Rule.......................... A-45

A.1.7 Step 6 - Specify the Tolerable Limits on Decision Errors . . . . . . . . . . . . A-46

A.1.7.1 False Rejection Decision Error. . . . . . . . . . . . . . . A-47

A.1.7.2 False Positive Decision Error . . . . . . . . . . . . . . . A-48

A.1.7.3 Statistical Model.......................... A-48

A.1.7.4 Quality Assurance/Quality Control .................. A-49

A.1.8 Step 7 - Optimize the Design for Obtaining Data . . . . . . . . . . . . A-50

A.1.8.1 General Investigation Strategy . . . . . . . . . . . . . A-50

A.1.8.2 Detailed Investigation Strategy $\ldots \ldots \ldots \ldots \ldots \ldots \ldots \ldots \ldots$ A-52

A.1.8.2.1 CAS 06-07-01, Area 6 Decontamination Facility ..... A-52

A.1.8.2.2 Area 15 EPA Farm . . . . . . . . . . . . . . . . A-54

A.1.9 References. . . . . . . . . . . . . . . . . . . . . . . . . . . . A-66 


\section{Table of Contents (Continued)}

Appendix A.2 - Project Organization $\ldots \ldots \ldots \ldots \ldots \ldots \ldots \ldots \ldots \ldots \ldots \ldots \ldots \ldots$

A.2 Project Organization . . . . . . . . . . . . . . . . . . . . . A-77

Appendix A.3 - Using the Visual Sampling Plan (VSP) for the Random Sample Design of CAS 06-07-01 and CAS 15-23-01 ................... A-78

Appendix A.4 - Response to NDEP Comments ......................899 


\section{List of Figures}

Number

Title

Page

1-1 Location of CAU 543 Corrective Action Sites ...................... 2

2-1 CAU 543, CAS 06-07-01, Decon Pad Site Map .................... 13

$2-2 \quad$ EPA Farm Site Map...................................... 17

4-1 CAU 543, CAS 06-07-01, Decon Pad, Septic System, and Piping Proposed Decision I Sample Locations. . . . . . . . . . . . . . . . . . . 52

4-2 CAU 543, CAS 06-07-01, Potential Decision I Sample Locations. . . . . . . . . . . 53

4-3 CAU 543, CAS 06-07-01, Decon Pad, Proposed Decision I Random Sample Locations ..................... 55

4-4 CAU 543, CAS 15-04-01, Septic Tank Proposed Decision I Sample Locations........................ 57

4-5 CAU 543, CAS 15-05-01, Leachfield

Proposed Decision I Sample Locations.......................... 58

4-6 CAU 543, CAS 15-08-01, Liquid Manure Tank

Proposed Decision I Sample Locations. . . . . . . . . . . . . . . . . . . . 59

4-7 CAU 543, CAS 15-23-03, Contaminated Sump, Piping Proposed Decision I Sample Locations. . . . . . . . . . . . . . . . . . . 60

4-8 CAU 543, CAS 15-01-03, Aboveground Storage Tank Proposed Decision I Sample Locations. . . . . . . . . . . . . . . . . 62

4-9 CAU 543, CAS 15-23-01, Underground Radioactive Material Area Proposed Decision I Random Sample Locations . . . . . . . . . . . . . . 63

A.1-1 Location of CAU 543 Corrective Action Sites . . . . . . . . . . . . . A-3

A.1-2 CAU 543, CAS 06-07-01, Decon Pad Site Map .................. A-6

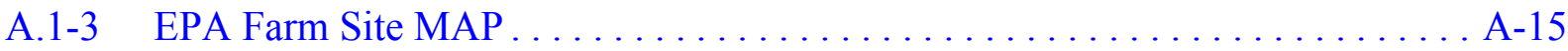




\section{List of Figures (Continued)}

Number

A.1-4 Process Flow Diagram for the Area 15 EPA Farm ............... A-27

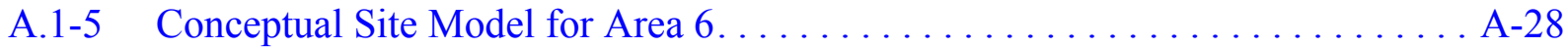

A.1-6 Conceptual Site Model for Area 15, EPA Farm Processes ............. A-30

A.1-7 CAU 543, CAS 06-07-01, Decon Pad, Septic System, and Piping Proposed Decision I Sample Locations.

A.1-8 CAU 543, CAS 06-07-01, Potential Decision I Sample Locations. . . . . . . . . . A-55

A.1-9 CAU 543, CAS 06-07-01, Decon Pad, Proposed Decision I Random Sampling Locations.................. A-56

A.1-10 CAU 543, CAS 15-04-01, Septic Tank Proposed Decision I Sample Locations. . . . . . . . . . . . . . . . . A-58

A.1-11 CAU 543, CAS 15-05-01, Leachfield

Proposed Decision I Sample Locations........................ A-59

A.1-12 CAU 543, CAS 15-08-01, Liquid Manure Tank

Proposed Decision I Sample Locations......................... A-61

A.1-13 CAU 543, CAS 15-23-03, Contaminated Sump, Piping Proposed Decision I Sample Locations . . . . . . . . . . . . . 62

A.1-14 CAU 543, CAS 15-01-03, Aboveground Storage Tank Proposed Decision I Sample Locations

A.1-15 CAU 543, CAS 15-23-01, Underground Radioactive Material Area Proposed Decision I Random Sample Locations A-65 


\section{List of Tables}

Number

Title

Page

3-1 CASs and Associated Releases and Applicable Conceptual Site Models . . . . . 31

3-2 Contaminants of Potential Concern for CAU $543 \ldots \ldots \ldots \ldots \ldots \ldots$

3-3 Analytical Requirements for Radionuclides for CAU $543 \ldots \ldots \ldots \ldots \ldots \ldots$. . . 41

3-4 Analytical Requirements for Nonradiological Analytes for CAU 543 . . . . . . . 42

4-1 General Geotechnical and Hydrological Analysis . . . . . . . . . . . . . . 64

5-1 Waste Management Regulations and Requirements $\ldots \ldots \ldots \ldots \ldots$

6-1 Laboratory and Analytical Performance Criteria for CAU 543

Data Quality Indicators. . . . . . . . . . . . . . . . . 78

A.1-1 Contaminants of Potential Concern for CAU $543 \ldots \ldots \ldots \ldots \ldots \ldots \ldots$. . . . 5

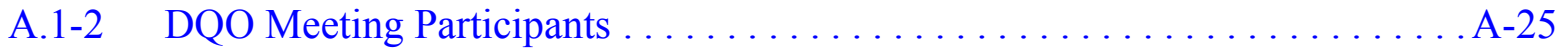

A.1-3 Information Needs to Resolve the Decision I and Decision II Decisions . . . . A-35

A.1-4 Analytical Methods for CAU 543 (Includes Environmental and

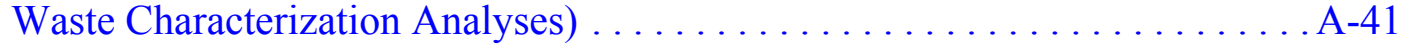

A.1-5 Laboratory Target Analytes for Nature of Contamination (Decision I)

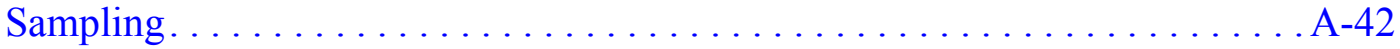

A.1-6 CAU 543 Spatial Boundaries . . . . . . . . . . . . . . . . . . A A-44 


\section{List of Acronyms and Abbreviations}

ACM Asbestos containing material

AEC U.S. Atomic Energy Commission

A-E Architect-Engineer

Am Americium

amsl Above mean sea level

AST Aboveground storage tank

ASTM American Society for Testing and Materials

bgs Below ground surface

BN Bechtel Nevada

CADD Corrective Action Decision Document

CAI Corrective action investigation

CAIP Corrective Action Investigation Plan

CAS Corrective Action Site

CAU Corrective Action Unit

CFR Code of Federal Regulations

CLP Contract Laboratory Program

Co Cobalt

COC Contaminant of concern

COPC Contaminant of potential concern

cpm Counts per minute

Cs Cesium

CSM Conceptual site model

DoD U.S. Department of Defense

DOE U.S. Department of Energy 


\section{List of Acronyms and Abbreviations (Continued)}

\begin{tabular}{|c|c|}
\hline DOT & U.S. Department of Transportation \\
\hline DQI & Data quality indicator \\
\hline DQO & Data quality objective \\
\hline EPA & U.S. Environmental Protection Agency \\
\hline ER & Environmental Restoration \\
\hline $\mathrm{Eu}$ & Europium \\
\hline FADL & Field activity daily log \\
\hline FFACO & Federal Facility Agreement and Consent Order \\
\hline FSL & Field-screening level \\
\hline FSR & Field-screening results \\
\hline $\mathrm{ft}$ & Foot \\
\hline $\mathrm{ft}^{3} / \mathrm{d} / \mathrm{ft}$ & Cubic feet per day per foot \\
\hline FWP & Field work plan \\
\hline gal & Gallon \\
\hline HASP & Health and Safety Plan \\
\hline HWAA & Hazardous waste accumulation area \\
\hline IDW & Investigation-derived waste \\
\hline in. & Inch \\
\hline IRIS & Integrated Risk Information System \\
\hline $\mathrm{km}$ & Kilometers \\
\hline $\mathrm{mi}$ & Mile \\
\hline $\mathrm{mg} / \mathrm{kg}$ & Milligrams per kilogram \\
\hline $\mathrm{mg} / \mathrm{L}$ & Milligrams per liter \\
\hline $\mathrm{mrem} / \mathrm{yr}$ & Millirems per year \\
\hline
\end{tabular}




\section{List of Acronyms and Abbreviations (Continued)}

\begin{tabular}{|c|c|}
\hline MRL & Minimum reporting limit \\
\hline MS & Matrix spike \\
\hline MSD & Matrix spike duplicate \\
\hline $\mathrm{M} \& \mathrm{O}$ & Management and Operating \\
\hline NAC & Nevada Administrative Code \\
\hline ND & Normalized difference \\
\hline NDEP & Nevada Division of Environmental Protection \\
\hline NEPA & National Environmental Policy Act \\
\hline NNSA/NSO & $\begin{array}{l}\text { U.S. Department of Energy, National Nuclear Security Administration } \\
\text { Nevada Site Office }\end{array}$ \\
\hline NTS & Nevada Test Site \\
\hline NTSWAC & Nevada Test Site Waste Acceptance Criteria \\
\hline PAL & Preliminary action level \\
\hline PCB & Polychlorinated biphenyls \\
\hline $\mathrm{pCi} / \mathrm{g}$ & Picocuries per gram \\
\hline $\mathrm{pCi} / \mathrm{L}$ & Picocuries per liter \\
\hline PPE & Personal protective equipment \\
\hline ppm & Parts per million \\
\hline PRG & Preliminary remediation goal \\
\hline PSP & Perforated steel planking \\
\hline $\mathrm{Pu}$ & Plutonium \\
\hline $\mathrm{PVC}$ & Polyvinyl chloride \\
\hline QA & Quality assurance \\
\hline QAPP & Quality Assurance Project Plan \\
\hline
\end{tabular}




\section{List of Acronyms and Abbreviations (Continued)}

$\begin{array}{ll}\text { QC } & \text { Quality control } \\ \text { RadCon } & \text { Radiological control } \\ \text { RCRA } & \text { Resource Conservation and Recovery Act } \\ \text { REECo } & \text { Reynolds Electrical \& Engineering Co., Inc. } \\ \text { RMA } & \text { Radioactive materials area } \\ \text { ROTC } & \text { Record of technical change } \\ \text { RPD } & \text { Relative percent difference } \\ \text { SD } & \text { Standard deviation } \\ \text { SDG } & \text { Sample delivery group } \\ \text { SDWA } & \text { Safe Drinking Water Act } \\ \text { SDWS } & \text { Safe Drinking Water Standards } \\ \text { SNJV } & \text { Stoller-Navarro Joint Venture } \\ \text { Sr } & \text { Strontium } \\ \text { SSHASP } & \text { Site-specific health and safety plan } \\ \text { SVOC } & \text { Semivolatile organic compound } \\ \text { TCE } & \text { Tetrachloroethylene } \\ \text { TCLP } & \text { Toxicity Characteristic Leaching Procedure } \\ \text { TPH } & \text { Total petroleum hydrocarbon } \\ \text { TSCA } & \text { Uranium } \\ \text { U } & \text { Uitified clay pipe } \\ \text { VOrganic compound }\end{array}$




\section{List of Acronyms and Abbreviations (Continued)}

VSP Visual Sample Plan

W Tungsten

$\% \mathrm{R} \quad$ Percent recovery 


\section{Executive Summary}

This Corrective Action Investigation Plan for Corrective Action Unit 543: Liquid Disposal Units, Nevada Test Site, Nevada, has been developed in accordance with the Federal Facility Agreement and Consent Order (1996) that was agreed to by the State of Nevada, the U.S. Department of Energy, and the U.S. Department of Defense. The general purpose of the investigation is to ensure that adequate data are collected to provide sufficient and reliable information to identify, evaluate, and select technically viable corrective actions.

Corrective Action Unit 543 is located in Areas 6 and 15 of the Nevada Test Site and is comprised of the following corrective action sites:

- 06-07-01, Decon Pad

- 15-01-03, Aboveground Storage Tank

- 15-04-01, Septic Tank

- 15-05-01, Leachfield

- 15-08-01, Liquid Manure Tank

- 15-23-01, Underground Radioactive Material Area

- 15-23-03, Contaminated Sump, Piping

This Corrective Action Investigation Plan provides investigative details for Corrective Action Unit 543, whereas programmatic aspects of this project are discussed in the Project Management Plan (DOE/NV, 1994). General field and laboratory quality assurance and quality control issues are presented in the Industrial Sites Quality Assurance Project Plan (NNSA/NV, 2002a). Health and safety aspects of the project are documented in the current version of the Environmental Services Architect-Engineer Contractor's Health and Safety Plan, and will be supplemented with a site-specific health and safety plan or equivalent.

Corrective Action Site 06-07-01, Decon Pad, is located in Area 6 and consists of the Area 6 Decontamination Facility and its components which are associated with decontamination of equipment, vehicles, and materials related to nuclear testing. The six corrective action sites in Area 15 are located at the U.S. Environmental Protection Agency Farm and are related to waste disposal activities at the farm. The farm was a fully functional dairy used to support animal experiments conducted at the on-site laboratory. 
The sources of possible contamination at Area 6 are a result of decontamination activities conducted within the Area 6 Decontamination Facility, which created potentially contaminated process waste effluent discharged through a process waste system. A sanitary waste stream was also generated within buildings of the Decontamination Facility. Radiologically contaminated materials were also stored within a portion of the facility yard and may have contributed to radioactive contamination at the facility. Sources of possible contamination at the Area 15 sites are associated with the dairy operations and the animal tests and experiments involving radionuclide uptake. The common sources of contamination to five of the corrective action sites are the liquid wastes generated within the laboratory, which were discharged via septic and/or process waste line systems to the various corrective action sites located on the farm. The sixth site, Corrective Action Site 15-23-01, is associated with decontamination of farm equipment and personnel.

Two conceptual site models were developed to identify the potential releases and migration pathways associated with the Area 6 corrective action site (06-07-01), and the six corrective action sites within the U.S. Environmental Protection Agency Farm in Area 15. The data quality objective process was used to identify and define the type, quantity, and quality of data needed to complete the investigation phase of the corrective action process. The data quality objectives address the primary problem that sufficient information on the nature and extent of potential contamination is not available to determine the appropriate corrective action for the Corrective Action Unit 543. To be able to determine the corrective action alternatives, two critical decisions were identified:

- Is a contaminant present in environmental media within the corrective action site at a concentration that could pose an unacceptable risk to human health and the environment?

- If a contaminant of concern is present, is sufficient information available to determine to what extent the contamination has migrated to the surrounding area?

For determining distinct data needs, resolution of the first decision is addressed as Decision I and resolution of the second decision is addressed as Decision II. Decision I data will be generated and evaluated throughout the corrective action sites. Decision II data will be generated and evaluated for each contaminant exceeding preliminary action levels in Decision I samples, as well as for all contaminants in certain biased sampling locations. Corrective action closure alternatives (i.e., no further action, close in place, or clean closure) will be recommended for Corrective Action Unit 543 based on an evaluation of all the data quality objective-related data. 
Based on site history, process knowledge, and previous investigations of similar sites, the contaminants of potential concern for Corrective Action Unit 543 include constituents associated with volatile organic compounds, semivolatile organic compounds, petroleum hydrocarbons, pesticides, herbicides, polychlorinated biphenyls, metals, and radionuclides.

The general technical approach for investigation of Corrective Action Unit 543 consists of, but is not limited to, the following activities:

- Perform video-mole surveys to identify potential breaches, cracks or leaks within septic and process waste system components.

- Collect environmental soil samples from random and/or biased locations and submit for laboratory analysis to determine if contaminants of concern are present and/or migrating.

- Collect additional environmental soil samples to define the lateral and vertical extent of contaminants of concern, if necessary.

- Collect samples of residual materials in tanks and piping, if present, for waste management purposes and corrective action evaluation.

- Perform radiological characterization surveys (scanning and static surveys and swipe collection) on solid materials to determine status for free release criteria.

- Collect required quality control samples.

- Stake or flag sample locations and record coordinates.

Additional samples may be collected and analyzed for the purpose of managing and disposing investigation-derived waste and developing corrective action alternatives.

Under the Federal Facility Agreement and Consent Order, this Corrective Action Investigation Plan will be submitted to the Nevada Division of Environmental Protection for approval. Field work will be conducted following approval of the plan. The results of the field investigation will support a defensible evaluation of corrective action alternatives that will be presented in the Corrective Action Decision Document. 


\subsection{Introduction}

This Corrective Action Investigation Plan (CAIP) contains project-specific information including facility descriptions, environmental sample collection objectives, and criteria for conducting site investigation activities at Corrective Action Unit (CAU) 543: Liquid Disposal Units, Nevada Test Site (NTS), Nevada.

This CAIP has been developed in accordance with the Federal Facility Agreement and Consent Order (FFACO) (1996) that was agreed to by the State of Nevada, the U.S. Department of Energy (DOE), and the U.S Department of Defense (DoD).

Corrective Action Unit 543 is located in Area 6 and Area 15 of the NTS, which is approximately 65 miles (mi) northwest of Las Vegas, Nevada (Figure 1-1). Seven corrective action sites (CASs) comprise CAU 543 and are listed below:

- 06-07-01, Decon Pad

- 15-01-03, Aboveground Storage Tank

- 15-04-01, Septic Tank

- 15-05-01, Leachfield

- 15-08-01, Liquid Manure Tank

- 15-23-01, Underground Radioactive Material Area

- 15-23-03, Contaminated Sump, Piping

Corrective Action Site 06-07-01, Decon Pad, is located in Area 6 and consists of the Area 6 Decontamination Facility and its components that are associated with decontamination of equipment, vehicles, and materials related to nuclear testing. The six CASs in Area 15 are located at the U.S. Environmental Protection Agency (EPA) Farm and are related to waste disposal activities at the EPA Farm. The EPA Farm was a fully-functional dairy associated with animal experiments conducted at the on-site laboratory.

The corrective action investigation (CAI) will include field inspections, video-mole surveys, and sampling of media, where appropriate. Data will also be obtained to support waste management decisions. 


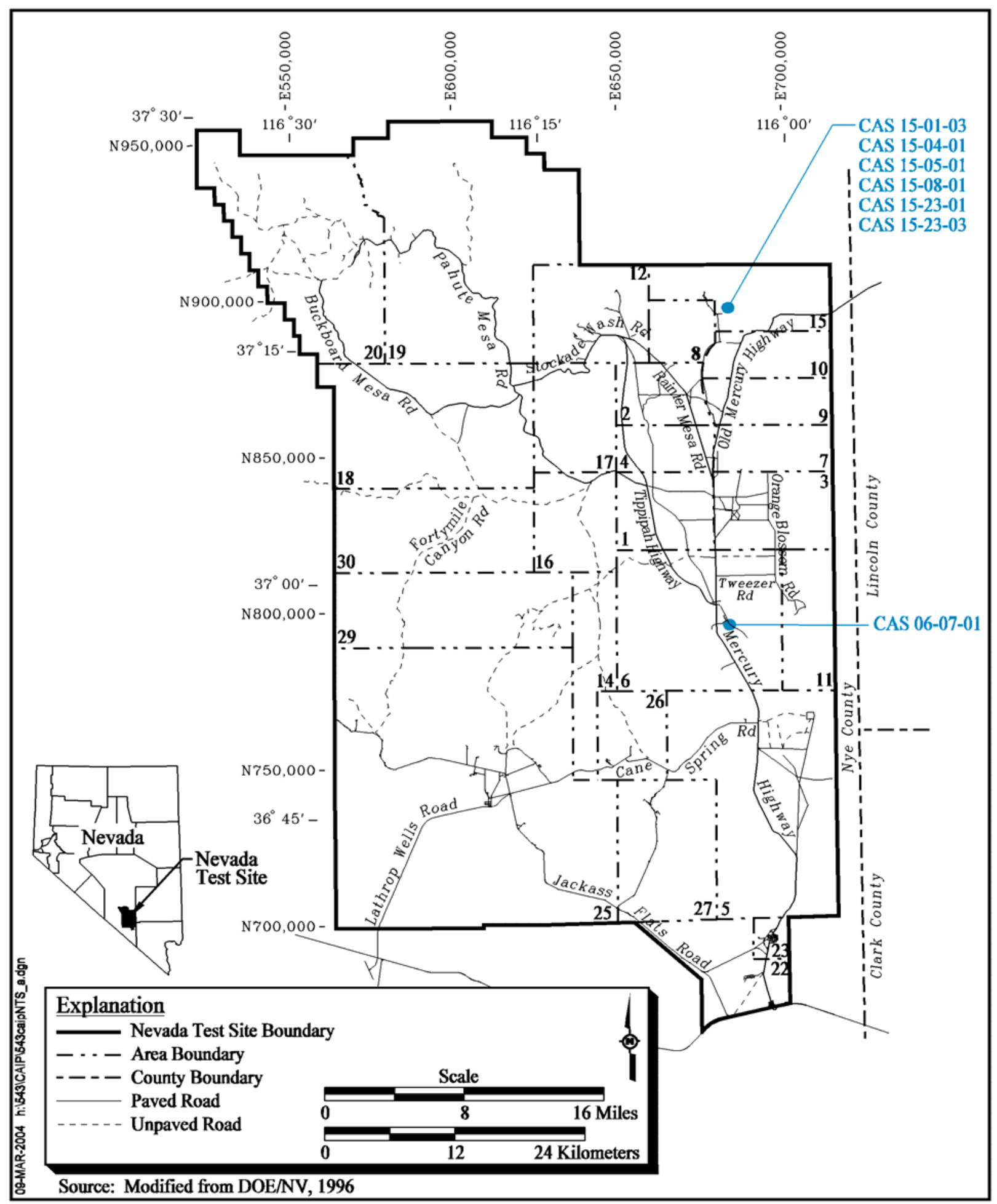

Figure 1-1

Location of CAU 543 Corrective Action Sites 


\subsection{Purpose}

The CASs within CAU 543 are being investigated because hazardous and/or radioactive constituents may be present at concentrations that could potentially pose a threat to human health and the environment. The seven CASs in CAU 543 primarily consist of sanitary and process waste collection, storage, and distribution systems (e.g., storage tanks, sumps, and piping). Existing information on the nature and extent of potential contamination at these sites is insufficient to evaluate and recommend corrective action alternatives for the CASs. Therefore, additional information will be obtained by conducting a CAI prior to evaluating corrective action alternatives and selecting the appropriate corrective action for each CAS.

\subsubsection{CAS History and Descriptions}

This section provides a brief history of each facility associated with CAU 543 (specifically, the Area 6 Decontamination Facility and the EPA Farm) as well as descriptions of the CASs and/or CAS components located at each of these facilities. Detailed descriptions and figures of each CAS are provided in Section 2.0 and Section A.1.1.

\subsubsection{Area 6 Decontamination Facility}

The Area 6 Decontamination Facility was built in 1971 and was designed to decontaminate vehicles, equipment, and clothing that had become radiologically contaminated during nuclear testing activities (DOE/NV, 1984 and 1993). Additionally, the facility managed mixed and radioactive waste generated from these decontamination processes. The site was identified through a review of the references associated with the Resource Conversation and Recovery Act (RCRA)/Environmental Restoration (ER) Site 06-05-02 (Area 6 Decontamination Pond). The Area 6 Decontamination Facility is located along the southwest edge of Yucca Lake in Area 6 of the NTS.

From 1971 through 1992, hazardous, radioactive, and sanitary wastes were generated within Building 6-605 (Area 6 Decontamination Pad), Building 6-607 (Area 6 Decontamination Laundry), Building 6-606 (Dyna Drill Repair Shop), and Trailer TA-20 (administrative office) and originally discharged via process waste lines, septic systems, and sumps to the Area 6 Decontamination Pond (DOE/NV, 1984; REECo, 1979a). Around 1992, liquid wastes were no longer discharged to the Decontamination Pond (Bingham, 1993; DOE/NV, 1992). In 1994, the waste collection/distribution 
system for the Area 6 Decontamination Facility underwent a significant upgrade in which a new process waste line system and aboveground storage tanks (ASTs) (i.e., Baker tanks) were installed to contain process liquid wastes prior to disposal and a new sanitary system was installed for domestic sewage to be discharged to the Area 6 Yucca Lake Lagoon System (REECo, 1994f; Bertrand, 2003). The Area 6 Decontamination Pond, located 600 feet $(\mathrm{ft})$ north of the facility, was the original discharge area for all liquid wastes generated within the facility until 1992. The Area 6 Decontamination Pond has been remediated and closed under CAU 92 (DOE/NV, 1999). The Area 6 Decontamination Facility remained operational until 2001 and is currently inactive and abandoned. Other buildings and/or structures within the perimeter fence of the Area 6 Decontamination Facility are not known to contribute effluent waste; therefore, they are not included in this CAS.

Additionally, a portion of the facility yard was used as a contaminated materials storage area where equipment and materials awaited decontamination. As a result, portions of the facility yard are posted as "Contamination Areas."

CAS 06-07-01, Decon Pad - The portions of this facility that will be investigated under this CAS consist of the following:

- Building 6-605 including the adjacent outdoor decontamination pad, all floor/trench drains, and three "hot caustic" dip tanks

- Inactive portions of the sanitary sewer systems from Buildings 6-605 and 6-607, which include the individual septic tanks and associated piping

- Inactive portions of the process waste-line system that formerly discharged wastes from Buildings 6-605, 6-606, and 6-607 to the former Area 6 Decontamination Pond which includes trench/floor drains, two sumps, and associated piping

- Surface soils located in the east portion of the facility yard that was formerly used to store contaminated materials

None of the waste-line components from the 1994 reconfigured process waste and sanitary waste systems are included in this CAS.

\subsubsection{Area 15, EPA Farm}

The EPA Farm was constructed in Area 15 of the NTS as a fully functional diary to support various studies including the transport of radioiodine from the environment to man, the uptake by plants of 
long-lived fission products, and metabolism studies (SWRHL, 1967; EPA, 1973). The majority of experiments occurred inside Laboratory Building 15-06 or nearby in the adjacent property. The CASs 15-01-03, 15-04-01, 15-05-01, 15-08-01, and 15-23-03 received effluents from Laboratory Building 15-06. The sixth CAS (15-23-01) is associated with decontamination activities that took place in a separate location of the EPA Farm. The rooms within the laboratory building included the hot slaughter room, milk room, milking area, sample control room, metabolism room, small animal laboratory, biology laboratory, autopsy laboratory, holding pen, utility room, rest room, and a change room for the workers.

The radioiodine studies ended in 1970 (EPA, 1980). The farm continued to be used until 1981 for other studies including metabolism studies on animals. By 1979, the farm no longer functioned as a full-time dairy and animals were only brought in for specific experiments. In 1981, the DOE decided to decontaminate and decommission the farm. In 1997, closure activities at the farm were completed (DOE/NV, 1998a). The EPA farm is inactive, abandoned, and the buildings have been removed. The following subsections provide brief descriptions of the six CASs associated with the EPA Farm in Area 15.

CAS 15-04-01 - This CAS consists of an 1,000-gallon (gal) septic tank, a cleanout, and the associated piping. The septic tank received both sanitary sewage and potentially contaminated effluent from floor drains and sinks within Building 15-06 (Holmes \& Narver, 1973a and b). Recent geophysical surveys were unable to confirm the presence of the septic tank; however, it is believed to be present (SAIC, 2003).

CAS 15-05-01 - This CAS consists of a distribution box, associated piping, and a leachfield associated with the 1,000-gal septic tank (CAS 15-04-01) that serviced building 15-06 (Holmes \& Narver, 1973a and b). The leachfield consists of two parallel, subsurface leach lines located about $8 \mathrm{ft}$ apart. The leach lines are constructed of 4-inch (in.) vitrified clay pipe (VCP) and measure approximately $70 \mathrm{ft}$ long. The leachfield received sanitary sewage and potentially contaminated effluent from floor drains and sinks located in Building 15-06 (Holmes \& Narver, 1973a and b).

CAS 15-08-01 - This CAS consists of a liquid manure tank and its associated piping; an outside floor drain within an adjacent concrete pad; and a 6-in. diameter metal pipe outfall and its associated piping located about $550 \mathrm{ft}$ south of the tank. The liquid manure tank is an 18,000-gal tank measuring 
$32 \times 12 \times 8 \mathrm{ft}$ with the top of the tank even with the ground surface. The liquid manure tank received liquid waste and excess milk from the metabolism area, milking parlor, milk room, and holding pen until 1972, after that time only effluent from the milking area and milk room discharged to the tank (SWRHL, 1967; EPA, 1977).

CAS 15-23-03 - This CAS consists of a sump measuring approximately 25 x 25 x $6 \mathrm{ft}$ deep with concrete sides and an unlined bottom and approximately $60 \mathrm{ft}$ of associated piping to the distribution box north of the sump. The sump and piping were installed in 1972 to accept nonradioactive or low-level radioactive wastes from the metabolism and slaughter rooms inside Building 15-06 (EPA, 1977; DOE, 1988; Olsen, 1997).

CAS 15-01-03 - This CAS consists of a 25,000-gal AST situated inside a bermed area, its contents, and the fill stand located adjacent to the berm; approximately $875 \mathrm{ft}$ of associated piping originating from Building 15-06 and the holding pens; a distribution box, a concrete drain box, and the surrounding soils. The AST, installed in 1974, received radioactive wastes from the metabolism and slaughter rooms within Building 15-06. The distribution box was used to divert nonradioactive wastes to the sump (CAS 15-23-03) and radioactive wastes to the AST (EPA, 1977; DOE, 1988; Olsen, 1997).

CAS 15-23-01 - This CAS consists of perforated steel planking (PSP) measuring approximately $22 \times 22 \mathrm{ft}$ and the soil surrounding and underlying the grate. The amount of soil affected is uncertain. This PSP may have been used as a decontamination area for farm workers and equipment coming out of the fields (Hopper, 1995; Sorom, 1995).

\subsubsection{Data Quality Objectives Summary}

The sites will be investigated based on data quality objectives (DQOs) developed by representatives of the Nevada Division of Environmental Protection (NDEP); DOE, National Nuclear Security Administration Nevada Site Office (NNSA/NSO); Stoller-Navarro Joint Venture (SNJV); and Bechtel Nevada $(\mathrm{BN})$. The DQO process is used to identify and define the type, amount, and quality of data needed to develop and evaluate appropriate corrective actions for CAU 543. This CAIP will describe the investigation developed to collect the data needs identified in the DQO process. While a 
detailed discussion of the DQO methodology and the DQOs specific to each CAS are presented in Appendix A.1, a summary of the results of the DQO process is provided below.

The DQO problem statement for CAU 543 is: "Existing information on the nature and extent of potential contamination is insufficient to evaluate and recommend corrective action alternatives for the CASs in CAU 543." To address this question, the resolution of two decisions statements is required:

- Decision I: "Is any contaminant of concern present in environmental media within the CAS at a concentration that could pose an unacceptable risk to human health and the environment?" A contaminant of concern (COC) is defined as any contaminant associated with a CAS activity that is present at concentrations exceeding its corresponding preliminary action level (PAL). If a COC is detected, then Decision II must be resolved. Otherwise, the investigation for that CAS is complete.

- Decision II: "If a COC is present, is sufficient information available to evaluate appropriate corrective action alternatives?" Sufficient information is defined as the data needs identified in the DQO process to include data needed to support waste management decisions and the maximum lateral and vertical extent of any COC within each CAS.

The informational inputs and data needs to resolve the problem statement and the decision statements were generated as part of the DQO process for this CAU and are documented in Appendix A.1. The information necessary to resolve the DQO decisions will be generated for each CAU 543 CAS by collecting and analyzing samples generated during a field investigation. The presence and nature of contamination at each CAS will be determined by sampling locations that are determined to be the most probable areas to contain COCs if they are present anywhere within the CAS. The absence of COCs within any CAS may also be established if the contaminant source material is determined not to contain COCs. If while defining the nature of contamination it is determined that COCs are present at a CAS, that CAS will be further addressed by determining the extent of contamination before evaluating corrective action alternatives.

\subsection{Scope}

To generate the information needed to resolve the decision statements identified in the DQO process, the scope of the CAI for CAU 543 includes the following activities:

- Move surface debris and/or materials, as needed, to facilitate sampling. 
- Perform video-mole surveys.

- Perform field screening.

- Collect and submit environmental samples for laboratory analysis to determine if COCs are present.

- If COCs are present, collect additional step-out samples to define the extent of the contamination.

- Collect samples of residual material in tanks and piping, if present, for waste management purposes and corrective action evaluation.

- Collect samples of investigation-derived waste (IDW), as needed, for waste management and minimization purposes.

- Collect Quality Control (QC) samples.

Soil contamination originating from activities not identified in the conceptual site model (CSM) of any CAS will not be considered as part of this CAU unless the CSM and the DQOs are modified to include the release. As such, contamination originating from these sources will not be considered for sample location selection, and/or will not be considered COCs for Decision II. If such contamination is present, the contamination will be identified as part of a new or other existing CASs.

\subsection{CAIP Contents}

Section 1.0 presents the purpose and scope of this CAIP, while Section 2.0 provides background information about CAU 543. Objectives of the investigation, including CSMs, are presented in Section 3.0. Field investigation and sampling activities are discussed in Section 4.0, and waste management issues are discussed in Section 5.0. General field and laboratory quality assurance (QA) and QC issues (including collection of QC samples) are presented in Section 6.0 and in the Industrial Sites Quality Assurance Project Plan (QAPP) (NNSA/NV, 2002). The project schedule and records availability are discussed in Section 7.0 and Section 8.0 provides a list of references.

Appendix A.1 provides a detailed discussion of the DQO methodology and the DQOs specific to each CAS, while Appendix A.2 contains information on the project organization. Appendix A.3 contains a description of the Visual Sample Plan (VSP) software (PNNL, 2002) and the criteria to be used for its use in selecting randomized sample locations, and Appendix A.4 contains NDEP comments. 
The health and safety aspects of this project will be documented in a site-specific health and safety plan (SSHASP), or equivalent prior to the start of field work.

Public involvement activities are documented in the "Public Involvement Plan" contained in Appendix V of the FFACO (1996). The managerial aspects of this project are discussed in the Project Management Plan (DOE/NV, 1994a) and will be supplemented with a site-specific field management plan that will be developed prior to field activities. 


\subsection{Facility Description}

Corrective Action Unit 543 is composed of seven CASs that were grouped together based on their geographical location, technical similarities, and agency responsibility for closure. The six CASs at the Area 15 EPA Farm were grouped together based on similar contaminant sources, operational histories, and related system components. The Area 6 CAS (06-07-01) was grouped in CAU 543 because of technical similarities with the Area 15 CASs (i.e., septic and process waste systems). The following sections provide an overview and background information regarding the physical setting and operational history, waste inventory, release information, and investigative background of the site.

\subsection{Physical Setting}

The following sections describe the general physical settings of Areas 6 (Yucca Flat) and Area 15 of the NTS. General background information pertaining to topography, geology, hydrogeology, and climatology are provided for these specific areas or the NTS region in the Geologic Map of the Nevada Test Site, Southern Nevada (USGS, 1990); CERCLA Preliminary Assessment of DOE'S Nevada Operations Office Nuclear Weapons Testing Areas (DRI, 1988); the Nevada Test Site Final Environmental Impact Statement (ERDA, 1977); and the Final Environmental Impact Statement for the Nevada Test Site and Off-Site Locations in the State of Nevada (DOE/NV, 1996).

Geological and hydrological setting descriptions for each of the CASs are detailed in the following subsections.

\subsubsection{Yucca Flat (Area 6)}

Corrective Action Site 06-07-01 is located in Area 6 on the southwest edge of Yucca Lake within the Yucca Flat Hydrographic Area of the NTS. Yucca Flat is a closed basin, which is slowly being filled with alluvial deposits eroding from the surrounding mountains (USGS, 1996). Paleozoic carbonate rocks primarily underlie the quaternary age alluvium in parts of Yucca Flat and form much of the surrounding mountains in this area. The soil classes present in the Yucca Flat area include stony, cobbly soils with moderately low available water-holding capacity (DOE/NV, 1996). Surface run-off collects at Yucca Lake, an ephemeral surface-water body at the southern end of Yucca Flat, 
approximately 0.6 kilometers $(\mathrm{km})(0.4 \mathrm{mi})$ northeast of CAS 06-07-01. Until it dissipates through evaporation or infiltration, surface water may be present in Yucca Lake for a few days or weeks. Vertical cracks attributed to natural desiccation of fine-grained materials and/or tectonic activity have opened in the playa deposits of Yucca Lake (USGS, 1985).

The direction of groundwater flow in Yucca Flat generally is from the northeast to southwest. Within the overlying alluvial and volcanic aquifers, lateral groundwater flow occurs from the margins to the center of the basin, and downward into the carbonate aquifer (USGS, 1996). The average annual precipitation at station UCC on the Yucca Flat dry lake is 6.62 in. (ARL/SORD, 2003). The recharge rate to the Yucca Flat area is relatively low due to the thickness of the unsaturated zone occurring to more than $600 \mathrm{ft}$ below ground surface (bgs) (USGS, 1996).

Groundwater test wells (Well C and Well C1) are located 13,200 ft south of CAS 06-07-01 at the southeastern tip of Yucca Lake. Both wells penetrate the Paleozoic carbonate aquifer through a $794 \mathrm{ft}$ thick tuff aquitard (USGS, 1968). At the site, the water table lies within the tuff aquitard at a depth of about $1,500 \mathrm{ft}$ above mean sea level (amsl). Any release would have to move about 1,000 $\mathrm{ft}$ through unsaturated material to reach the water table. The possibility exists for accelerated vertical migration through local fractures (DOE/NV, 1994b).

\subsubsection{Area 15}

The EPA Farm is located within the northern portion of the Ash Meadows subbasin. The groundwater flows to the south-southwest, toward Death Valley and Ash Meadows. Beneath the EPA Farm lies the welded-tuff aquifer and tuff confining unit (DOE/NV, 2000a; USGS, 1996). It is suspected that groundwater may be produced from all transmissive lithologic units, with 80 percent coming from 5,200 and 5,300 ft bgs (DRI, 1993; SWRHL, 1967). Perched water is not apparent at the EPA Farm.

Average annual precipitation, which is recorded at the Public Health Services Station, has been monitored since its inception in 1964. However, precipitation averages do not include data prior to 1965. The average annual precipitation is 7.4 in. with past low and high year readings of 2.2 and 15.6 in., respectively (ARL/SORD, 2003). Precipitation recharge to the Ash Meadows subbasin occurs along the subbasin mountain ranges. 
The nearest well to the EPA Farm is UE-15d, which is located $50 \mathrm{ft}$ north of Building 15-06. This well was used mainly for irrigation. The bottom 2,598 ft of UE-15d pipe is slotted with an open bottom. On March 27, 1962, an aquifer test was conducted at the well that determined the specific capacity to be 166 cubic feet per day per foot $\left(\mathrm{ft}^{3} / \mathrm{d} / \mathrm{ft}\right)$ (DRI, 1993). The depth to groundwater was recorded at $667 \mathrm{ft}$ bgs on October 2, 1963 (USGS, 1965). On January 13, 1983, the depth to groundwater was recorded at $686 \mathrm{ft}$ bgs. The well was used as part of the Long-Term Hydrologic Monitoring Program, but the pump inside the well failed on April 16, 1990, and the well has been inactive since (DRI, 1993). The nearest drinking water well to the EPA Farm is Water Well 2, which is located in Area 2 approximately $4 \mathrm{mi}$ southwest of the CAS and down gradient from the site. This water well is used primarily for industrial use, and water levels range from 2,053 to 2,066 ft bgs (USGS and DOE, 2003).

\subsection{Operational History}

The following subsections provide a description of the use and history of each of the CASs in CAU 543 that may have resulted in a potential release to the environment. The following CAS- and facility-specific summaries are designed to illustrate any significant, known activities. Section A.1.1 in Appendix A.1 provides additional discussion of each CAS.

\subsubsection{Area 6 Decontamination Facility}

The Area 6 Decontamination Facility (Figure 2-1) was built in 1971 and was designed to decontaminate vehicles, equipment, and clothing that had become radiologically contaminated during nuclear testing activities (DOE/NV, 1984 and 1993; Holmes \& Narver, Inc. 1971b). Additionally, the facility managed mixed and radioactive waste generated from these decontamination processes. The Area 6 Decontamination Facility is located along the southwest edge of Yucca Lake in Area 6 of the NTS and consisted of several buildings and structures within a fenced area. These buildings and structures include:

- Area 6 Decontamination Pad (Building 6-605) and an associated outdoor concrete pad

- Area 6 Decontamination Laundry (Building 6-607)

- Dyna Drill Repair Shop (Building 6-606)

- Dyna Drill Repair Parts (Building 06-2203A)

- Tent Structure 06-202567

- Trailer TA-20 on a concrete foundation 


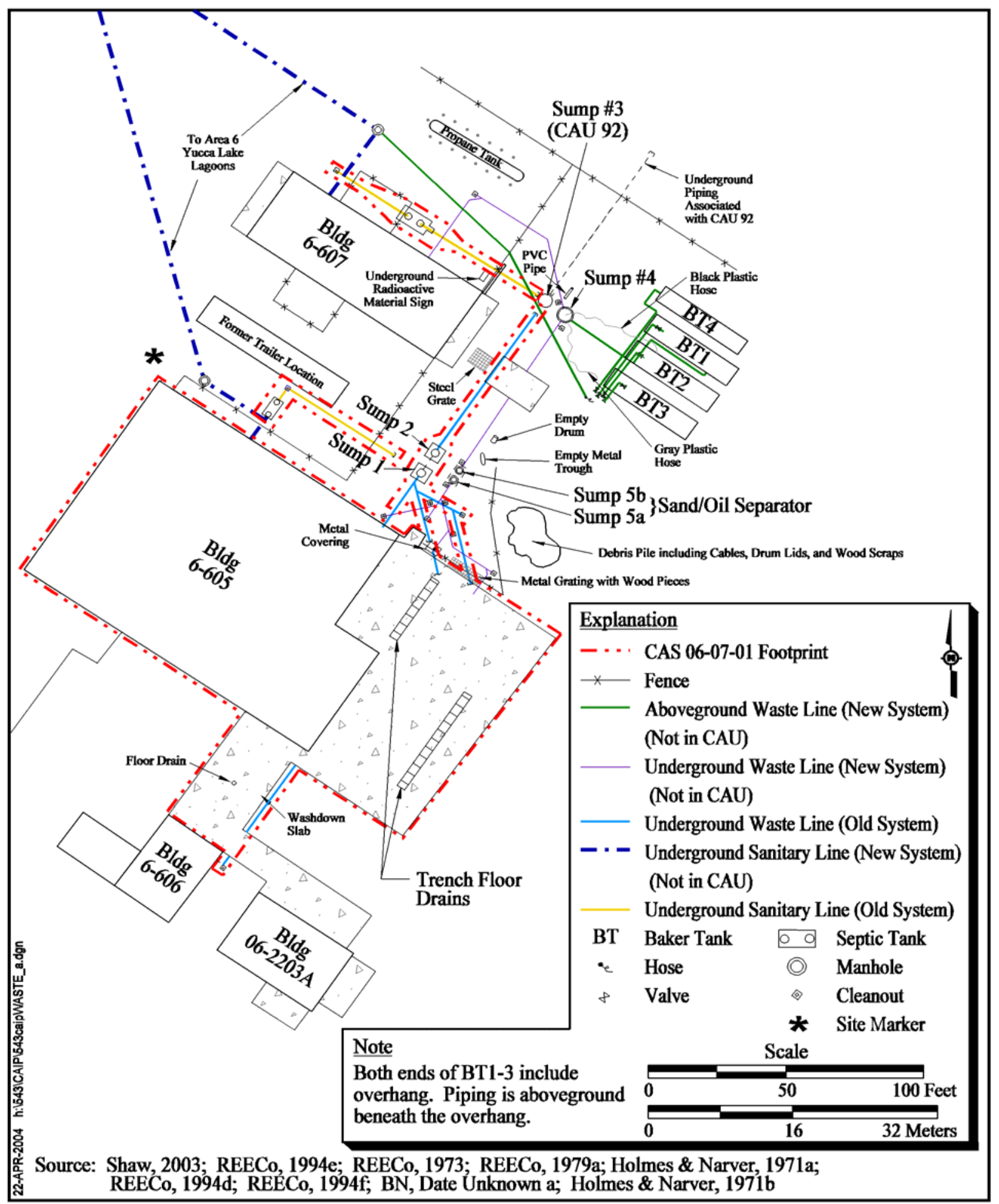

Figure 2-1

CAU 543, CAS 06-07-01, Decon Pad Site Map 
- An electrical substation

- Various other temporary containers and sheds

- Storage area for contaminated materials

The Area 6 Decontamination Pond, located $600 \mathrm{ft}$ northeast of the facility, was the original discharge area for all liquid wastes generated within the facility buildings until the pond was closed in 1992. The Area 6 Decontamination Pond, associated piping from the pond to Sump 3 located within the facility perimeter fence, and Sump 3 have been remediated and closed under CAU 92 (DOE/NV, 1999).

The Area 6 Decontamination Facility was built to decontaminate vehicles, equipment, and clothing that had become radiologically contaminated during nuclear testing activities. From 1971 through 1992, hazardous, radioactive, and sanitary wastes were generated within Buildings 6-605, 6-606, 6-607, and Trailer TA-20 and originally discharged via process waste lines, septic systems, and sumps to the Area 6 Decontamination Pond located north of the facility (REECo, 1979a; DOE/NV, 1999). Until November 1988, the waste generated at CAS 06-07-01 contained RCRA constituents; however, after this date, wastes containing RCRA constituents were no longer allowed to be discharged into this waste system (Bicker, 1988). Around 1992, liquid wastes were no longer allowed to be discharged to the Decontamination Pond (Bingham, 1993). In 1994, the Area 6 Decontamination Facility waste collection/discharge system underwent a significant upgrade in which a new process waste line system and ASTs (i.e., Baker tanks) were installed to contain all liquid wastes generated within the buildings prior to disposal. The sanitary sewer lines were reconfigured to discharge domestic sewage to the Area 6 Yucca Lake Lagoon System. The Area 6 Decontamination Facility remained operational until approximately 2001 and is currently inactive and abandoned (Shaw, 2003; Soong, 2003).

\subsubsection{CAS 06-07-01, Decon Pad}

The portions of the Area 6 Decontamination Facility to be investigated under CAU 543 consist of Building 6-605 (Area 6 Decontamination Pad) and its associated outdoor decontamination pad; inactive portions of the sanitary sewer systems for Buildings 6-605 and 6-607; inactive portions of the process waste lines and sumps that formerly discharged wastes from Buildings 6-605, 6-606, and 6-607 to the former Area 6 Decontamination Pond, and the soils located in eastern portions of the facility that were used to store contaminated materials. The new components of the 1994 
reconfigured system are not included under this CAU but are added for knowledge of the current system (Bertrand, 2003; Paradis, 2003).

Building 6-605, built in 1971, is the main decontamination facility and is referred to as the Area 6 Decontamination Pad. The building contains both a high and low bay equipped to accommodate both large (i.e., drill rigs) and smaller vehicles and equipment. The primary decontamination process for radiologically contaminated materials involved spraying water, mixed with cleaning solvents and soaps/detergents, onto contaminated materials inside the bays. Electronic equipment and materials that could be damaged by water were cleaned using solvents, such as alcohol. Three dip tanks containing hot caustics were also located within the building and were used to submerge and clean smaller pieces of equipment (REECo, 1971b; DOE/NV, 1984). An outdoor decontamination pad sits adjacent to the building and contains a floor drain. It is assumed decontamination activities were conducted on this pad as well. Trenches with floor drains are located within and outside of Building 6-605 to collect the waste streams generated from decontamination activities.

Building 6-607, the Area 6 Decontamination Laundry, was used to clean clothing and other fabrics contaminated with potentially radioactive and hazardous material from NTS testing activities (Wuellner, 1994). Building 6-606, the Dyna-Drill Repair Shop, was located south of Building 6-605 (REECo, 1979a). The building was used to fix pipes and other drill parts that were decontaminated within the Area 6 Decontamination Facility. Building 6-606 has been removed. Documentation indicates both of these buildings conducted activities that generated and contributed a liquid waste stream to the CAS 06-07-01.

The Trailer TA-20 was an administrative office located northwest of Building 6-605. Activities conducted within this trailer, other than administrative, are unknown. The trailer had an aboveground polyvinyl chloride (PVC) line that connected directly into Building 6-605 sanitary sewer line and it is believed the trailer discharged only sanitary waste (Radack, 1992). The trailer or PVC piping is no longer present; however, the concrete foundation remains.

The Dyna-Drill Repair Parts, Building 6-2203A, is located southwest of Building 6-605 (REECo, 1979a). The building was used in conjunction with the Dyna-Drill Repair Shop; however, specific activities are unknown. The Tent Structure, Building 6-202567, is located southwest of Building 6-605 and was used to store various wastes. The majority of these wastes were stored in 
B25 steel boxes. Documentation and process knowledge indicates these buildings were not directly related to the decontamination activities of Building 6-605; therefore, they did not contribute liquid wastes via a process or sewer waste line.

The southeast portion of the facility, formerly used to store contaminated materials, is currently posted as a "Contamination Area." Engineering drawings identify this area as the "Hot Side" and the "Hot Park Area" (Holmes \& Narver, 1971a). Specific details of activities conducted within this area, other than storage, are unknown.

\subsubsection{The EPA Farm}

The six remaining CASs in CAU 543 are located at the EPA Farm in Area 15 of the NTS. Figure 2-2 shows the general layout of the Area 15 EPA Farm and its associated CASs. In 1963, the U.S. Atomic Energy Commission (AEC) (predecessor to the DOE) awarded a contract to the U.S. Public Health Service (USPHS) to study the transport of radioiodine from the environment to man, as well as the uptake by plants of long-lived fission products (SWRHL, 1967). The USPHS Farm was constructed in Area 15 of the NTS as a fully functional dairy to support these studies (EPA, 1973). The location of the farm was chosen based on the UE-15d Well, the location of roads and powerlines, and the fall-out in the area from the Plowshare Program. The radioiodine studies ended in 1970, at which time the USPHS was renamed the EPA. Various names have been used interchangeably for both the farm and the main building (EPA, 1980). The farm has been referred to as the EPA Farm, the USPHS Farm, and the PHS Farm. The main building has been referred to as Building 15-06, the Laboratory Building, the EPA Dairy Barn, and the Experimental Dairy Barn (DRI, 1994). The farm continued to be used until 1981 for other animal studies including metabolism studies. By 1979, the farm no long functioned as a full-time dairy and animals were only brought in for specific experiments. On December 31, 1981, the DOE decided to decontaminate and decommission the farm. On October 23, 1997, closure activities at the farm, consisting of removing building structures and sealing floor drains, were completed (DOE/NV, 1998a). The EPA Farm has been determined to be eligible for the National Register of Historic Places.

The majority of activities that generated and discharged effluent wastes to the CASs of CAU 543 occurred inside Laboratory Building 15-06 or at adjacent property (i.e., holding pens). Those activities are believed to have consisted of animal tissue sampling and experiments, slaughter and 


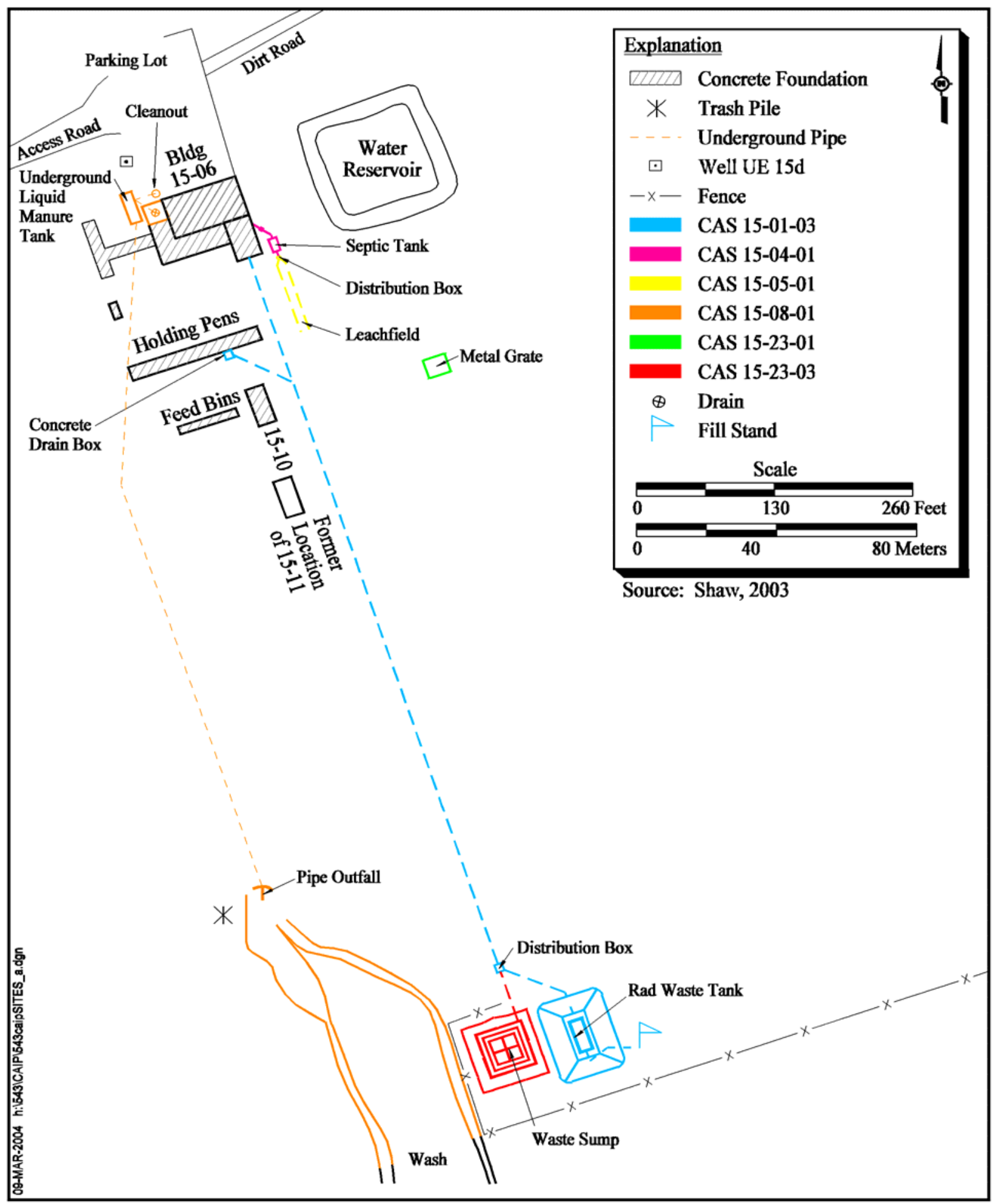

Figure 2-2

EPA Farm Site Map 
milking activities, metabolism studies, and other laboratory testing (EPA, 1973 and 1980; DRI, 1994). The CASs 15-04-01, 15-05-01, 15-08-01, 15-23-03, and 15-01-03 received effluent waste from rooms within Laboratory Building 15-06 (Holmes \& Narver, 1971, 1974, 1975, and 1979). Liquid wastes were discharged through floor drains within the following rooms: the hot slaughter room, milk room, milking area, sample control room, metabolism room, small animal laboratory (Edward B. Hendricks, 1965a, b, and c), biology laboratory, autopsy laboratory, holding pen, utility room, rest room, and a change room for the workers. Drawings and documentation indicate that wastes from the small animal and biology laboratories, utility room, and rest room were disposed into the septic system that consists of a septic tank (CAS 15-04-01) and leachfield (CAS 15-05-01) (Holmes \& Narver, 1973a and b). During the planning stages of the farm, there was a concern regarding the disposal of excess milk from the dairy herd and the adverse effects it might have on the biochemical activity in the septic tank. In addressing the concern, a commercially available liquid manure system was installed in 1965 to be used for the accumulation of liquid waste and excess milk from the dairy operations. Wastes from the metabolism area, milking parlor, milk room, and holding pen were disposed of in this liquid manure tank (CAS 15-08-01) (SWRHL, 1967). After 1972, the liquid manure tank received only effluent from the milking area and milk room (EPA, 1977). Wastes from the metabolism and slaughter rooms were originally disposed via a waste line into an unlined sump (CAS 15-23-03) (Holmes \& Narver, 1972a and b). In approximately 1974, an AST (CAS 15-01-03) was installed east of the sump to accept higher-level radiological wastes (EPA, 1977). The wastes originating from both rooms were diverted at a distribution box between the AST and the sump, with the radiological wastes going to the AST and the nonradioactive or low-level wastes going to the sump (DOE, 1988; Olsen, 1997). The wastes from holding pens were also believed to have been disposed into the AST via the same waste line (Holmes \& Narver, 1971c).

This sixth CAS (15-23-01), is an area southeast of Building 15-06 that was reportedly used as a decontamination area for farm equipment and possibly personnel who worked in the crop fields (Hopper, 1995 and 2003; Sorom, 1995). The crop fields were grown to support the feeding of cattle used in the EPA Farm experiments and were historically sprayed with contaminated manure waste, iodine-131, tritiated water, pesticides, and herbicides. Decontamination was conducted at this location in order to prevent the spread of contamination from the "hot" east side of the farm to the “cold" west side of the farm (Holmes \& Narver, Inc. 1971a). This CAS was originally identified as a contaminated dry waste well located beneath a grain silo next to Trailer 15-12. However, through 
numerous interviews, documentation review, and geophysical data review, it is believed this well does not exist at the site. However, the "well" may have referred to a pit or sump filled with coarse gravel.

The following subsections provide a brief description of each CAS located at the EPA Farm. Refer to Figure 2-2 for a general view of each CAS location.

\subsubsection{CAS 15-04-01, Septic Tank}

According to engineering drawings this CAS is located adjacent and east of Building 15-06. Drawings and documentation indicate that wastes from the small animal laboratory, biology laboratory, utility room, and rest room were disposed into the septic system consisting of a septic tank (CAS 15-04-01) and leachfield (CAS 15-05-01). This CAS consists of a 1,000-gal septic tank, cleanout, and associated piping. The piping consist of 4 -in. cast-iron pipe from the building to the cleanout, where the pipe changes to 4-in. VCP from the cleanout to the septic tank (Edward B. Hendricks, 1965a). A recent geophysical survey and field observations were not able to confirm if the septic tank is still present at the site (SAIC, 2003). It is possible the tank was removed, or the tank location fell outside the geophysical survey boundary. The most recent sampling documentation states the tank contained approximately 800 gal of liquid and sludge waste (DOE/NV, 1995).

\subsubsection{CAS 15-05-01, Leachfield}

This CAS is located adjacent and east of Building 15-06. Drawings and documentation indicate that wastes from the small animal laboratory, biology laboratory, utility room, and rest room were disposed into the septic system which consists of a septic tank (CAS 15-04-01) and leachfield (CAS 15-05-01) (Edward B. Hendricks, 1965a). This CAS consists of the distribution box, associated piping, and leachfield associated with the 1,000-gal septic tank (CAS 15-04-01) that serviced Building 15-06. The leachfield consists of two subsurface 70-ft long leach lines that are $8 \mathrm{ft}$ apart extending south from the distribution box (Edward B. Hendricks, 1965a). The leach lines consist of perforated 4-in. VCP. The dimensions for the distribution box are unknown. Recent geophysical survey data were able to identify anomalies consistent with underground piping (SAIC, 2003). 


\subsubsection{CAS 15-08-01, Liquid Manure Tank}

This CAS is located adjacent to the northwest corner of the Building 15-06 foundation and consists of a liquid manure tank and its associated piping. Wastes from the metabolism area, milking parlor, milk room, and holding pen were disposed of to this tank (Edward B. Hendricks, 1965b). After 1972, the liquid manure tank only received effluent from the milking area and milk room (EPA, 1977). The liquid manure tank consists of an 18,000-gal underground concrete tank that measures $32 \times 12 \times 8 \mathrm{ft}$ with the top of the tank even with the ground surface. Included in the CAS is piping between the tank and the building and the outside floor drain in the center of a concrete pad. Also included in this CAS is outflow piping that extends south from the tank approximately $550 \mathrm{ft}$ to a drainage wash. The 6-in. diameter outflow pipe, south of Building 15-06, surfaces from the ground at the head of the wash. The wash is approximately 4 to $5 \mathrm{ft}$ wide and 2 to $3 \mathrm{ft}$ deep.

The manure tank had a clock-operated agitator to keep the solids in suspension (SWRHL, 1967). A special chopper pump emptied the tank into a tank wagon, which was used to spread the contents over the crop fields. According to an interview (Hopper, 2003), the liquid wastes in the tank were pumped into an outflow pipe and allowed to flow south, eventually discharging into the small wash. An outflow pipe was identified during a field visit that was located south of Building 15-06. Further, a geophysical survey conducted in March 2003 identified a line that connects the manure tank to the outflow pipe (SAIC, 2003). It is believed that this outflow line was used to discharge wastes from the liquid manure tank; however, no documentation has been found that details these activities.

\subsubsection{CAS 15-23-03, Contaminated Sump, Piping}

This CAS is located approximately $875 \mathrm{ft}$ south of the Building 15-06 foundation at the EPA Farm. This CAS consists of a $25 \times 25 \times 6$-ft deep sump and subsurface piping extending approximately $60 \mathrm{ft}$ north to a distribution box. The dimensions of the distribution box are approximately $31 \times 36$ in. The sides of the sump are constructed of concrete angled at 45 degrees and the bottom is unlined. Currently, there are metal stakes and chicken wire covering the entire sump area. Wastes from the metabolism and slaughter rooms were originally disposed of via a waste line into this sump (DRI, 1988; Hopper, 2003). In approximately 1974, an AST (CAS 15-01-03) was installed east of the sump to accept higher level radiological wastes. The wastes originating from both rooms were diverted at a distribution box between the AST and the sump, with the radiological wastes going to 
the AST and the nonradioactive or low-level wastes going to the sump (Olsen, 1997). The sump area is posted with “Underground Radioactive Material” signs (DOE/NV, 2000a; Shaw, 2003).

\subsubsection{CAS 15-01-03, Aboveground Storage Tank}

This CAS is located approximately $875 \mathrm{ft}$ south of Building 15-06 and includes the 25,000-gal AST, its contents, and the fill stand located within the bermed area; approximately $875 \mathrm{ft}$ of associated piping originating from Building 15-06 and the holding pens; the distribution box (31 x 36 in.) located approximately $60 \mathrm{ft}$ from the AST; the concrete drain box located at the holding pens, and the potentially affected soil surrounding each feature. Wastes from the metabolism and slaughter rooms were originally disposed via a waste line into an unlined sump (CAS 15-23-03) (Holmes \& Narver, 1971c). In approximately 1974, the AST was installed east of the sump to accept higher level radiological wastes (EPA, 1977). The wastes originating from both rooms were diverted at a distribution box between the AST and the sump, with the radiological wastes going to the AST and the nonradioactive or low-level wastes going to the sump (DOE, 1988; Olsen, 1997). The cylindrical AST is located within a pit and is approximately $31 \mathrm{ft}$ long and $21 \mathrm{ft}$ in diameter, with an estimated capacity of 25,000 gal. A gauge on top of the AST reads approximately 24,000 gal. If the gauge reads correctly, the tank is full. The exact contents of the AST are uncertain. An engineering drawing shows a pump motor located at the southern end of the AST as well as piping that branches northwest from the main line to a concrete drain box located at the holding pens (REECo, 1975).

During a site visit in February 2003, staining was observed on the sides of the tank near the southernmost access ports. Tumble weeds in the pit hinder viewing the bottom of the pit for any possible staining. It is believed that the AST may have released contaminants to the surface soil at some time during the operation of the facility (Shaw, 2003). The piping on the southern end of the tank, near the fill stand, is covered with what may be asbestos-containing material (ACM). The fill stand is located on the eastern edge of the berm.

\subsubsection{CAS 15-23-01, Underground Radioactive Material Area}

This CAS is located southeast of Building 15-06 and approximately $150 \mathrm{ft}$ south of the septic tank. The CAS consists of PSP measuring approximately $22 \times 22 \mathrm{ft}$ and the surrounding and underlying 
soil. The CAS was originally identified as a contaminated dry waste-well located beneath the grain silo next to Trailer 15-12. However, through numerous interviews, a review of historical documentation, and geophysical survey results, it is believed that the well does not, nor did it ever, exist at the site. The term "well" may have been used at one time to describe a pit or a sump filled with coarse gravel. The area is currently posted as an "Underground Radioactive Material Area."

\subsection{Waste Inventory}

Available documentation, interviews with former site employees, process knowledge, and general historical NTS practices were used to identify wastes that may be present. More detailed information was evaluated during the DQO process and is discussed in Section A.1.1 of Appendix A.1. The following summarizes the types of waste and associated contaminants expected or suspected to be present at each CAS.

\subsubsection{CAS 06-07-01, Decon Pad}

Decontamination activities conducted within Building 6-605 created effluent potentially contaminated with cleaning solvents, soaps/detergents, degreasers, hot caustics, acids, and various radionuclides from contaminated materials. The effluent was discharged through floor drains via a process waste line to two sumps labeled Sump 1 (sand trap) and Sump 2 (oil/water separator) located northeast of the building (REECo, 1973). Documentation states that due to numerous caustic and acidic spills and abrasive actions caused by drill pipe and heavy equipment, the concrete floor of Building 6-605 started to breakdown. As a result, the product Stonclad was applied over the entire floor to protect the concrete floor from further erosive attacks (Western, 1977).

In addition to the process wastes generated, Building 6-605 generated sanitary effluent that discharged through drains to a septic tank and eventually to the process waste line at Sump 1 (REECo, 1973). Based on process knowledge gained from previous septic system investigations on the NTS, the sanitary effluent may have had hazardous and/or radioactive contamination present. In 1992, floating debris and oil were noted in the septic tank adjacent to Building 6-605 and is believed to be the result of overflow from clogged process waste lines (Radack, 1992). 
Building 6-607 (Area 6 Decontamination Laundry) used soaps and detergents to clean the contaminated clothing used during testing and drilling activities. Effluent from Building 6-607 was potentially contaminated with various inorganic and organic compounds and radionuclides and entered the septic system at Sump 3 (REECo, 1973). In addition, Building 6-607 generated sanitary effluent that discharged through drains to a septic tank and eventually to the process waste at Sump 3. Based on process knowledge gained from previous septic systems investigations on the NTS, the sanitary effluent may have hazardous and/or radioactive contaminants present.

Effluent from Building 6-606 likely contained solvents, degreasers, and lubricant that may have been used during equipment repair activities. Effluent discharged through drains and entered the processwaste line south of Building 6-605. A concrete pad with a floor drain is located between Buildings 6-606 and 6-605. It is assumed this drain also contributed effluent to the process-waste line but exact activities for this pad are unknown; however, at a minimum surface run-off would be generated.

Radioactive contamination was released to the surface soils within portions of the facility yard as determined by radiological survey data and the subsequent posting of areas as "Contamination Areas."

\subsubsection{EPA Farm}

The primary activities at the EPA Farm consisted of common practices associated with a fully functional dairy operation (e.g., milking, growing crops, holding pens) and the animal tests and experiments involving radionuclide uptake conducted within Laboratory Building 15-06. The common sources of contamination and waste streams generated at the EPA Farm are applicable to all the Area 15 CASs and are described in this section.

Laboratory wastes associated with animal experiments, autopsy laboratory, metabolism laboratory, slaughter room, holding pen, and the milk room in Building 15-06 were discharged to CASs 15-04-01, 15-05-01, 15-08-01, 15-23-01, and 15-01-03 (Edward B. Hendricks, 1965a, b, and c; Holmes \& Narver, 1972, 1974, 1975, and 1979). Based on historical documentation and process knowledge these wastes may contain radionuclides, biological wastes (e.g., contaminated urine, feces, milk, and blood), laboratory chemicals (acids), and other potentially hazardous constituents 
such as PCBs, metals, pesticides, and herbicides (SWRHL, 1967; EPA, 1973, 1977, and 1980; DOE, 1988; Hopper, 1995 and 2003).

Domestic sewage wastes from the animal laboratory, biology laboratory, utility room, and rest room of Building 15-06 were discharged to CASs 15-04-01 and 15-05-01. Based on process knowledge and historical disposal practices, these wastes may include radioactive and/or hazardous constituents (Holmes \& Narver, 1973a and b).

Building and farm management operations included the use and storage of pesticides, herbicides, fertilizers (SWRHL, 1967 and Boehlecke, 1997), and petroleum products for equipment (e.g., grease, oil, and diesel). Based on process knowledge and historical disposal practices, these constituents may be found in any of the waste streams generated within Building 15-06 or the decontamination area.

Decontamination fluids may have been discharged to the soils underlying and surrounding CAS 15-23-01 from the decontamination of farm workers and equipment used in managing the crops planted at the farm (Hopper, 1995 and 2003; Sorom, 1995). Based on process knowledge, the liquid wastes associated with these decontamination activities may include degreasers, solvents, detergents, hydrocarbons, radionuclides, pesticides, herbicides, metals, and polychlorinated biphenyls (PCBs).

There is a potential that wastewater discharges from Well UE-15d may have been disposed of down drains at the EPA Farm, resulting in the following contaminants being introduced into the EPA Farm waste stream: iron, manganese, lead, and mercury. These contaminants exceeded the Safe Drinking Water Act (SDWA) contaminant levels in 1984 (DOE, 1988).

\subsection{Release Information}

The release information, migration routes, exposure pathways, and affected media are discussed in this section. Based on historical information and process knowledge, the primary sources of potential environmental contaminants released to the soil within CAU 543 include:

- Potentially contaminated effluent collected and discharged through sanitary and process waste systems from Area 6 decontamination activities and storage of contaminated materials

- Potentially contaminated effluent collected and discharged through sanitary and process waste systems from laboratory experiments and decontamination activities at the Area 15 EPA Farm 
Potentially affected media for all CASs include surface and shallow subsurface soils beneath and surrounding the sumps, septic tanks, underground storage tank (UST)/ASTs, and associated piping as a result of either designed or accidental releases of contaminants. Additional media affected by potential contamination include the components of piping, tanks, concrete pads, drains, and building structures in direct contact with potential contaminants.

Releases of contaminants to the surface environment are most likely to have occurred at transfer points, overflows, surface spills, and fill locations at tanks; overflows into the wash; run-off areas at decontamination pads, the unlined sump floor; and contaminated storage areas. Subsurface releases of contaminants are most likely to occur at junctions of system components (i.e., piping to tank), at breaches in the tanks, sumps, distribution boxes, and leach lines; and at breaches, cracks, or leaks in piping.

Exposure routes to site workers include ingestion, inhalation, and/or dermal contact (absorption) from disturbance of contaminated soils, debris, structures, and possibly ACMs (i.e., transite). Site workers may also be exposed to radiation by performing activities in proximity to radiologically contaminated materials.

Migration of potential contamination is assumed to be minimal based on the affinity of the contaminants of potential concern (COPCs) for soil particles, and the low precipitation and high evapotranspiration rates typical of the NTS environment. Contaminants may have been transported by infiltration and percolation of precipitation through soil, which would serve as the primary driving force for downward migration. Based on the release points within both Area 6 and Area 15, migration would be expected primarily downward with horizontal migration to a much lessor degree. Contaminants migrating to regional aquifers are not considered a likely scenario at CAU 543 based on the average depth to groundwater, the low annual average precipitation rates, the high potential for evapotranspiration, and the low mobility of expected COPCs. Additional information on migration, exposure routes, and affected media is presented in Section 3.1.3 and in Section A.1.2.3 of Appendix A.1. 


\section{$2.5 \quad$ Investigative Background}

Previous site investigation activities associated with CAU 543 were identified during the preliminary assessment. Details of these investigations are provided in Section A.1.1 of Appendix A.1. The following paragraphs summarize all known investigation activities conducted at each CAS.

\subsubsection{CAS 06-07-01, Decon Pad}

Sampling results from the Area 6 Decontamination Pond (CAU 92), the septic tanks that serviced Buildings 6-605 and 6-607, Sumps 1 and 2, and soil from around the process-waste lines indicated the presence of numerous potential contaminants. Results indicate the presence of various solvents, acids, caustics, degreasers, detergents, alcohols, metals, radionuclides, petroleum hydrocarbons, volatile organic compounds (VOCs), and semivolatile organic compounds (SVOCs)

(DOE/NV, 1999). Specific sample concentration data from several sample reports are available in the CAU 543 Project file (Shaw, 2003) and in the CAU 92 Corrective Action Decision Document (CADD) (DOE/NV, 1999).

Sampling results from closure of tank 6-605-1 indicate that petroleum hydrocarbons were present in concentrations as high as 13,000 milligrams per kilogram $(\mathrm{mg} / \mathrm{kg})$ and that contaminants had migrated in the soil underneath Building 6-605 (DOE/NV, 2000a).

\subsubsection{CAS 15-04-01, Septic Tank}

This septic tank was sampled as part of the Preliminary Characterization of Abandoned Septic Tank Systems (DOE/NV, 1995). In this study, this septic system is identified as A15EPA. When sampled on September 12, 1994, the tank contained approximately 800 gal of waste, including an estimated 2-ft layer of sludge. The liquid was relatively clear with floating particles and the sludge was dark brown to black and viscous. One liquid sample (A15EPA-T-L) and one sludge sample (A15EPA-T-S) were collected. The liquid sample was analyzed for total petroleum hydrocarbons (TPH), VOCs, SVOCs, metals, PCBs, oil and grease, gamma radiation, beta/tritium, and plutonium. The sludge samples was analyzed for the same parameters using the total characteristic leaching procedure (TCLP) method for VOCs, SVOCs, and metals. The concentrations for oil and grease and $\mathrm{TPH}$ as oil in the sludge sample $(1,600 \mathrm{mg} / \mathrm{kg}$ and $1,130 \mathrm{mg} / \mathrm{kg}$, respectively) led to a 
recommendation that the septic system be closed as a "hydrocarbon containing tank." Barium; chlorobenzene; 1,4-dichlorobenzene; a PCB; and naturally occurring and man-made radionuclides were detected; however, none of them exceeded applicable federal action or NDEP guidance levels. The $\mathrm{pH}$ ranged from 7.02 units to 8.28 units, which is not considered hazardous under 40 Code of Federal Regulations (CFR) 261.22 for corrosivity (CFR, 2002a).

A geophysical survey was conducted over an area where the septic tank was shown to be located on engineering drawings in March 2003 (SAIC, 2003). According to the survey, only anomalies consistent with underground piping were identified. No septic tank was located during the survey. It is possible that the tank may have been removed, or the area containing the tank may have fallen outside the boundaries of the survey. No documentation was located to support the removal of the septic tank.

\subsubsection{CAS 15-05-01, Leachfield}

The leachfield was sampled as part of the Preliminary Characterization of Abandoned Septic Tank Systems (DOE/NV, 1995). In this study, this septic system is identified as A15EPA. On March 27, 1995, one soil sample was collected below the first identified leachfield tile perforation analyzed for TPH, TCLP VOCs, TCLP SVOCs, TCLP and total metals, PCBs, oil and grease, gamma radiation, beta/tritium, and plutonium. Barium, cadmium, chromium, oil and grease, tetrachloroethylene (TCE), and naturally occurring radionuclides were detected in the leachfield soil sample; however, concentrations were below applicable federal action and NDEP guidance levels. The $\mathrm{pH}$ of the sample was 7.52 units and is not hazardous under 40 CFR 261.22 for corrosivity (CFR, 2002a). Semivolatile organic compounds, TPH, and PCBs were not detected above laboratory reporting limits in the leachfield soil sample.

A geophysical survey was conducted to determine the location and dimensions of the leachfield at CAS 15-05-01 in March 2003 (SAIC, 2003). Various anomalies consistent with underground piping were identified that may potentially be the piping associated with the leachfield. 


\subsubsection{CAS 15-08-01, Liquid Manure Tank}

A geophysical survey, conducted at CAS 15-08-01 during March 2003, identified the underground line associated with the outflow at the southern end of the farm (SAIC, 2003). The line ran north approximately $550 \mathrm{ft}$ to the liquid manure tank.

Radiological surveys performed in August 1997 in support the CAU 95 closure did not identify any removable-surface or fixed-surface contamination in the areas of Building 15-06 (DOE/NV, 1998a). Radiological walk-over surveys performed during February 2003 included CAS 15-08-01. No risk to individuals from residual radiological contamination was identified (Nicosia, 2003).

\subsubsection{CAS 15-23-03, Contaminated Sump, Piping}

A demarcation survey of the EPA Farm area was conducted on August 6, 1998. The figure that accompanies the report indicates the EPA Farm Pond Underground Radioactive Material Area Boundary and the EPA Farm Storage Tank Contamination Area Boundary are one boundary (DOE/NV, 2000). This boundary encompasses both the sump and the AST. The radionuclides in the soil are expected to be americium and plutonium; however the subsurface concentrations of radioactivity are unknown. The DOE/NV (2000) report states that the subsurface soils contained unknown levels of radionuclide activity but the surface-soil removable activity was well below 10 CFR 835 guidelines.

\subsubsection{CAS 15-01-03, Aboveground Storage Tank}

No specific investigation results were identified for this CAS.

\subsubsection{CAS 15-23-01, Underground Radioactive Materials Area}

A site monitoring/site demarcation survey of Area 15 site dry well was performed in May 1991 (Smith, 1991). The sketch on the checklist indicates an area that is consistent with the description of this CAS. The survey was conducted at four location at the dry well, 270 degrees west, 180 degrees south, 90 degrees east, and 360 degrees north. The results for beta/gamma were 100 counts per minute (cpm), $100 \mathrm{cpm}, 120 \mathrm{cpm}$, and $100 \mathrm{cpm}$, respectively. For alpha, the results were $0 \mathrm{cpm}$ at all locations. 
Radiological walk-over surveys performed at the NTS during February 2003 included CAS 15-23-01. No radiological contamination was identified (Nicosia, 2003).

A geophysical survey was conducted at CAS 15-23-01 in March 2003 (SAIC, 2003). Four anomalies were identified in the area. Anomaly "D" corresponds with the PSP that is located at the surface of CAS 15-23-01.

\subsection{National Environmental Policy Act}

In accordance with the NNSA/NSO National Environmental Policy Act (NEPA) Compliance Program, a NEPA checklist will be completed prior to commencement of site investigation activities at CAU 543. This checklist is used by NNSA/NSO project personnel to evaluate their proposed projects against a list of several potential impacts which include, but are not limited to: air quality, chemical use, waste generation, noise level, and land use. Completion of the checklist results in a determination of the appropriate level of NEPA documentation by the NNSA/NSO NEPA Compliance Officer. 


\subsection{Objectives}

This section presents an overview of the DQOs for CAU 543 and formulation of the CSMs. Also presented is a summary listing of the COPCs and PALs. Additional details and figures depicting the CSMs are located in Appendix A.1.

\subsection{Conceptual Site Models}

The CSMs describe the most probable scenario for current conditions at a site and defines the assumptions that are the basis for identifying appropriate sampling strategy and data collection methods. Two CSMs have been developed for CAU 543 using assumptions formulated from the physical setting, historical background information, potential contaminant sources, knowledge from similar sites, release information, historical background information, and physical and chemical properties of the potentially affected media and COPCs. The two CSMs were developed to identify the potential release from the Area 6 CAS (06-07-01) and the six CASs within the EPA Farm in Area 15 of the NTS. The two CSMs identify the failure or leaking from septic tanks and underground piping, releases from tanks during overfilling or transfer of contents to other containers, overspray, run-off, and infiltration from decontamination activities, and release from stored contaminated material. Appendix A.1 provides more detailed information on the CSM as presented for DQO formulation. Table 3-1 identifies how the potential sources relate to the suspected contaminants identified in the CSM for the CASs in CAU 543.

If evidence of potential contamination that is outside the scope of the presented CSMs is identified during investigation activities, the situation will be reviewed and a recommendation will be made as to how best to proceed. In such cases, identified decision makers will be notified and given the opportunity to comment on and/or concur with the recommendation.

The following sections discuss future land use and the identification of exposure pathways (i.e., combination of source, release, migration, exposure point, and receptor exposure route) for the CAU. 
Table 3-1

CASs and Associated Releases and Applicable Conceptual Site Models

\begin{tabular}{|c|c|c|}
\hline CAS Description & Releases Associated with CAS & $\begin{array}{c}\text { Conceptual Site } \\
\text { Model(s) }\end{array}$ \\
\hline 06-07-01, Decontamination Pad & $\begin{array}{l}\text { - Subsurface releases from abandoned septic system } \\
\text { components associated with Buildings 6-605, 6-606, } \\
\text { and 6-607 } \\
\text { - Subsurface release from floor drains, dip tanks, and } \\
\text { recirculation tanks in Building 6-605 } \\
\text { - Surface releases from outside decontamination } \\
\text { activities and outside storage of contaminated } \\
\text { equipment and materials }\end{array}$ & - Area 6 CSM \\
\hline 15-01-03, Aboveground Storage Tank & $\begin{array}{l}\text { - Subsurface releases from underground piping and } \\
\text { distribution box } \\
\text { - Surface releases from pumping and overflow events }\end{array}$ & - EPA Farm CSM \\
\hline 15-04-01, Septic Tank & $\begin{array}{l}\text { - Subsurface releases from abandoned septic system } \\
\text { associated with Building 15-06 }\end{array}$ & - EPA Farm CSM \\
\hline 15-05-01, Leachfield & $\begin{array}{l}\text { - Subsurface releases from abandoned leachfield } \\
\text { associated with CAS 15-04-01 }\end{array}$ & - EPA Farm CSM \\
\hline 15-08-01, Liquid Manure Tank & $\begin{array}{l}\text { - Subsurface releases from underground liquid manure } \\
\text { storage tank } \\
\text { - Surface releases from pumping and overflow events }\end{array}$ & - EPA Farm CSM \\
\hline $\begin{array}{l}\text { 15-23-01, Underground Radioactive } \\
\text { Material Area }\end{array}$ & $\begin{array}{l}\text { - Surface release and infiltration from decontamination } \\
\text { activities }\end{array}$ & - EPA Farm CSM \\
\hline 15-23-03, Contaminated Sump, Piping & $\begin{array}{l}\text { - Subsurface releases from underground piping } \\
\text { - Surface releases from unlined sump }\end{array}$ & - EPA Farm CSM \\
\hline
\end{tabular}

\subsubsection{Future Land Use}

As described in this section, the land-use zones where the CAU 543 CASs are located indicate that future land uses will be limited to nonresidential (i.e., industrial) activities.

Corrective Action Site 06-07-01 is located in the land-use zone described as "Defense Industrial Zone." This area is designated for continued support of the activities and studies that may take place within the NTS. Activities are expected to continue as they are currently being conducted with some variation in the frequency and occurring on a demand basis (DOE/NV, 1998b).

Corrective Action Sites 15-04-01, 15-05-01, 15-08-01, 15-01-03, 15-23-03, and 15-23-01 are located with land-use zones described as "Reserved" within the NTS. This area includes land and facilities 
that provide widespread flexible support for diverse short-term testing and experimentation. The reserved zone is also used for short duration exercises and training such as nuclear emergency response, Federal Radiological Monitoring and Assessment Center training, and DoD.

\subsubsection{Contaminant Sources}

This section presents the suspected sources of contamination within each CAS within CAU 543 as depicted in each of the two CSMs.

Area 6 Decontamination Conceptual Site Model (\#1) sources are:

- Releases from the interior of Building 6-605. The building contains several dip and recirculation tanks where cleaning agents were used to decontaminate various drilling tools and small equipment. These tanks were emptied into the floor drains that lead from the building to the process-waste system and then to the Decontamination Pond. Large equipment was decontaminated in either the high or low bay areas where high pressure washers were use to clean the equipment. The decontamination fluid flowed into the trench drains and eventually to the process-waste system. In addition to the waste-process line leading from the building, a septic tank collected sanitary waste from the toiles, sinks, and showers in Building 6-605. The outflow of the septic tanks entered the waste process line at Sump 1. Releases may have occurred through cracks or breaches in the piping, trench drains, septic tank, or the cement floor and may have included solvent, degreasers, detergents, petroleum products, acids, and caustics.

- Release from Buildings 6-605 and 6-606. During the active life of the facility various buildings released contaminated liquid through the old waste-process line. The system originally included piping that lead from Buildings 6-605 and 6-606 to two sumps that served as a sand separator (Sump 1) and oil/water separator (Sumps 2) for the waste-process line. Building 6-607 (Laundry) discharged into the waste-process line down-stream from the two sumps. During the renovation in 1994, the old system was replaced with a new system that is not included within this CAS. Releases may have included solvents, degreasers, detergents, petroleum products, PCBs, acids, and caustics through cracks or breaks in the sumps or piping.

- Release from Building 6-607 (Laundry). This building housed the laundry facilities for the clothing the workers wore when operating the drilling or testing equipment. The contaminated clothing was washed and the gray water was discharged to the old process-waste system. A septic tank received the sanitary waste for the showers, sinks, and toilets. The septic tank was connected directly to the old process-waste downstream from Sump 1. Releases may have occurred through cracks or breaches in the septic tank or associated piping. 
- Release from the Building 6-605 outdoor decontamination pad. Large equipment was initially washed on the outdoor decontamination pads prior to a complete decontamination inside Building 6-605. The pad was equipped with trench drains that collected sediment and wash fluid and channeled them to the sand separator (Sump 1) and then to the oil/water separator (Sump 2) prior to discharging into the Decontamination Ponds. Releases may have occurred as overspray from the decontamination activities, run-off from the concrete pad to the surrounding soil, or through cracks in the drain and piping.

- Release from Building 6-606 (Dyna Drill Repair Shop). Little is known about what processes occurred in this building but it is assumed that drilling equipment was repaired and maintained. These activities may have released solvents, degreasers, petroleum products, and detergents to the process-waste system for discharge to the Decontamination Pond. Subsurface releases my have occurred through breaks or cracks in the process system piping.

- Equipment and material stored outside Building 6-605 may have released radioactive contaminants to the soil surface. Leaks from the equipment may have also release petroleum product to the surface soils.

Area 15, EPA Farm Conceptual Site Model (\#2) sources are:

- The activities and experiments conducted in Building 15-06 are considered the primary source of contamination at the EPA Farm. The COPCs include laboratory chemicals, fecal material, urine, milk, contaminated animal organs, and cleaning solutions from the slaughter and autopsy rooms, and laboratories. Five of the CASs were constructed or installed to manage the waste that originated in the laboratories or milking rooms of the building. The releases may have occurred through overfills or transfers from the tanks, leaks from cracks or breaks in septic tanks or piping, surface discharges from overflow piping or into the Contaminated Sump.

- CAS 15-23-01 is the only CAS that is not directly connected to Building 15-06. This small decontamination pad was used to clean farm machinery and personnel returning from working in the fields. Release from this CAS would have been surface deposits on the surface soil and included petroleum from the equipment and radionuclides from the soil on the farm equipment.

\subsubsection{Release Mechanisms}

Release mechanisms for the CSMs are primarily leaks from piping and tanks into the subsurface soil or spills and leaks onto the surface soil. 


\subsubsection{Migration Pathways}

Migration pathways at the CASs within CAU 543 are expected to be generally limited to vertical migration through the surface and near-surface soil. All CASs, except 15-08-01, have very minor surface gradients and are not located in drainage channels. Included in CAS 15-08-01 in the overflow piping from the manure tank that discharges into the small wash approximately $550 \mathrm{ft}$ from Building 15-06. This may allow minor lateral flow, but because of the permeable soil in the wash, infiltration would still be the dominant migration pathway. The migration pathway for the decontamination pad in Area 6 also includes lateral movement along the concrete to the surrounding soil.

Infiltration and percolation of precipitation serves as the driving force for downward migration of contaminants. However, potential evapotranspiration (the evaporative capacity of the atmosphere at the soil surface) at the NTS is significantly greater than precipitation, thus limiting vertical migration of contaminants. The annual average precipitation for this region is 3 to 6 in. per year (USGS, 1975). The total annual potential evapotranspiration at the Area 3 Radiological Waste Management Site has been estimate at $62.6 \mathrm{in}$. (Shott et al., 1997). These data indicate that evapotranspiration is the dominant factor influencing the movement of water in the upper unsaturated zone. Therefore, recharge to groundwater from precipitation is not significant at the NTS and does not provide a significant mechanism for migration of contaminants to groundwater. Because the facilities within the CAU are no longer active, any liquid discharges that may have provided a downward driving force no longer exist which further reduces the potential impact to the groundwater.

Fate and transport are influenced by distinguishing physical and chemical characteristics of the contaminants and media. Contaminant characteristics include solubility, density, and adsorption potential. Media characteristics include permeability, porosity, water saturation, sorting, chemical composition, and organic content. In general, contaminants with low solubility, high affinity for media, and high density can be expected to be found relatively close to release points. Contaminants with high solubility, low affinity for media, and low density can be expected to be found further from release points.

Contamination, if present, is expected to be contiguous to the site, except where multiple sites and activities are adjacent. In these cases, migration from one site may have impacted the immediately 
adjacent site. For all CAU 543 CSMs, concentrations of contaminants are expected to decrease with horizontal and vertical distance from the location of the release.

\subsubsection{Exposure Points}

The exposure points for both CSMs are expected to be discrete locations of surface or shallow subsurface contamination where visitors and site workers will come in contact with surface and shallow subsurface soil.

\subsubsection{Exposure Routes}

Exposure routes to site workers, and visitors include oral ingestion, inhalation, and/or dermal contact (absorption) from disturbance of contaminated soils. Site workers may also be exposed to radiation by performing activities in proximity to radiologically contaminated materials.

\subsubsection{Additional Information}

Topographic information, climatic conditions, groundwater data, and flood plane information for the CAU are well documented. These are available and have been addressed in the CSM or will be considered during corrective action, as necessary. Additional topographic information for CAU 543 will not be necessary because the data available are adequate to make determinations about the CASs and components. Average annual precipitation measurements are presented in Section 2.1.1 through Section 2.1.2. Groundwater data for the CAU is known and has been addressed in the CSM. The CAS-specific depth to groundwater data are presented in Section 2.1.1 through Section 2.1.2. Existing floodplain studies are available and will be considered during corrective action, as necessary. No further information is required.

General surface and subsurface soil description as well as specific structure descriptions will be observed and recorded during the CAI. A utility survey will be conducted at each CAS to avoid underground utilities and to maintain a safe work environment. Active working utilities will not be impacted by the investigation. 


\subsection{Contaminants of Potential Concern}

Suspected contaminants for CAU 543 were identified through a review of site historical documentation, employee interviews, process knowledge, past investigation efforts, and inferred activities associated with the CASs. Suspected contaminants for each CAU 543 CAS are listed in Table 3-2 as developed during the DQO process.

Table 3-2

Contaminants of Potential Concern for CAU 543*

\begin{tabular}{|c|c|c|c|c|c|c|c|}
\hline Analytical Parameter & 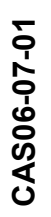 & 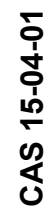 & 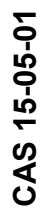 & 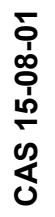 & 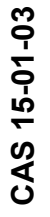 & 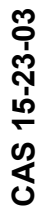 & 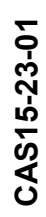 \\
\hline \multicolumn{8}{|c|}{ Organics } \\
\hline Total Volatile Organic Compounds & $\mathrm{X}$ & $\mathrm{X}$ & $X$ & $\mathrm{X}$ & $X$ & $\mathrm{X}$ & $\mathrm{X}$ \\
\hline Total Semivolatile Organic Compounds & $\mathrm{X}$ & $\mathrm{X}$ & $\mathrm{X}$ & $\mathrm{X}$ & $X$ & $X$ & $\mathrm{X}$ \\
\hline Pesticides & & $X$ & $X$ & $X$ & $X$ & $X$ & $X$ \\
\hline Herbicides & & $X$ & $X$ & $X$ & $X$ & $X$ & $X$ \\
\hline Polychlorinated Biphenyls & $X$ & $X$ & $X$ & $X$ & $X$ & $X$ & $X$ \\
\hline$\left[\mathrm{C}_{6}-\mathrm{C}_{10}\right]$ gasoline-range & $X$ & $X$ & $X$ & $X$ & & $X$ & $X$ \\
\hline$\left[\mathrm{C}_{10}-\mathrm{C}_{38}\right]$ diesel-range & $X$ & $X$ & $X$ & $X$ & & $X$ & $X$ \\
\hline \multicolumn{8}{|c|}{ Metals } \\
\hline $\begin{array}{l}\text { Total Resource Conservation and Recovery } \\
\text { Act metals }\end{array}$ & $X$ & $X$ & $X$ & $X$ & & $X$ & $X$ \\
\hline Total Beryllium & $X$ & $X$ & $X$ & $X$ & $X$ & $X$ & $X$ \\
\hline \multicolumn{8}{|c|}{ Radionuclides } \\
\hline Strontium-90 & $X$ & $X$ & $X$ & $X$ & $X$ & $X$ & $X$ \\
\hline Isotopic Plutonium & $\mathrm{X}$ & $\mathrm{X}$ & $X$ & $X$ & $\mathrm{X}$ & $\mathrm{X}$ & $X$ \\
\hline Isotopic Uranium & $\mathrm{X}$ & $\mathrm{X}$ & $\mathrm{X}$ & $X$ & $\mathrm{X}$ & $\mathrm{X}$ & $\mathrm{X}$ \\
\hline
\end{tabular}

*Footnotes:

- Critical contaminants of potential concern (i.e., analytes) are listed in Table A.1-1.

- Analytical methods for each analytical parameter are listed in Tables 3-3 and 3-4.

- Laboratory-specific analytes detected by each analytical methods are listed in Table A.1-5. 
Because complete information regarding activities performed at the CAU 543 CASs and components is unavailable, additional analytes have been included as COPCs. These are reflected in the analytical program for the CAU 543 investigation described in Section 3.4. Chemical COPCs are defined as the analytes detected using the analytical methods for which the EPA Region 9 has established preliminary remediation goals (PRGs) (EPA, 2002) for which toxicity data are listed in the EPA Integrated Risk Information System (IRIS) database (EPA, 2003). Radiological COPCs are defined as the radionuclides detected using the analytical methods listed in Section 3.4

At a given CAS or component, each COPC that is detected in a sample at concentration exceeding the corresponding PAL becomes a COC for subsequent sampling to define the extent of contamination (Decision II).

Some of the chemicals used at CAU 543 sites are potential RCRA contaminants. The historical literature for the CASs has been thoroughly reviewed. When applicable, the sample locations, source of data, data date, constituents, site processes, and activities at each CAS were reviewed. There is insufficient process knowledge to consider any chemicals "RCRA listed" at the CAU 543 sites (Franky, 2003). If analytical results indicate the presence of RCRA contaminants, they will be evaluated as potential "characteristic" wastes. Total results will be calculated as theoretical TCLP values, if necessary TCLP analysis will be requested for samples to ensure full RCRA characterization (CFR, 2003a).

\subsection{Preliminary Action Levels}

Laboratory analytical results for soil samples will be compared to the following PALs to evaluate if COCs are present or migrating:

- EPA Region 9 Risk-Based Preliminary Remediation Goals for chemical constituents in industrial soils (EPA, 2002).

- Background concentrations for RCRA metals, zinc, and beryllium will be used instead of PRGs when natural background exceeds the PRG, as is often the case with arsenic on the NTS. Background is considered the mean plus two standard deviations of the mean for sediment samples collected by the Nevada Bureau of Mines and Geology throughout the Nevada Test and Training Range (formerly the Nellis Air Force Range) (NBMG, 1998; Moore, 1999). 
- The TPH action limit of 100 parts per million (ppm) per the Nevada Administrative Code (NAC) 445A.2272 (NAC, 2002e).

- The PALs for radionuclides, except those covered by DOE Order 5400.5 (DOE, 1993), were taken from the construction, commercial, industrial land-use scenario in Table 2.1 of the NCRP Report No. 129, Recommended Screening Limits for Contaminated Surface Soil and Review Factors Relevant to Site-Specific Studies (NCRP, 1999). The values provided in this source document are based on a 25 millirems per year (mrem/yr) dose but have been scaled to a $15 \mathrm{mrem} / \mathrm{yr}$ dose for the purpose of this investigation.

- For detected chemical COPCs without established PRGs that are listed in the EPA IRIS database (EPA, 2002), the protocol used by the EPA Region 9 in establishing PRGs (or similar) will be used in establishing the PALs.

Solid media such as concrete and/or structures may pose a potential radiological exposure risk to site workers, if contaminated. The radiological PAL for solid media will be defined as the unrestricted-release criteria defined in the NV/YMP Radiological Control (RadCon) Manual (DOE/NV, 2000b).

The selected PALs are based on the EPA Region 9 Industrial Land-Use PRGs. The PRGs are risk-based tools for evaluating and cleaning up contaminated sites that estimate contaminant concentrations in environmental media (e.g., soil, air, and water) that EPA considers protective of humans (including sensitive groups) over a lifetime. The toxicity based PALs have been calculated for an industrial-use scenario. The industrial-use scenario is applicable to sites at the NTS based on future land-use scenarios as presented in Section 3.1.1 and agreements between NDEP and NNSA/NSO.

The conservative level of $100 \mathrm{ppm}$ for TPH is based on a regulatory mandate from the State of Nevada and is used as a "clean-up" level.

Radiochemistry PALs are based on a scaling of the NCRP $25 \mathrm{mrem} / \mathrm{yr}$ dose-based levels (NCRP, 1999) to a conservative $15 \mathrm{mrem} / \mathrm{yr}$ and the recommended levels for certain radionuclides in DOE Order 5400.5 Change 2 (DOE, 1993). These PALs are based on the construction, commercial, industrial land-use scenario provided in the guidance and are appropriate for the NTS based on future land use scenarios as presented in Section 3.1.1. These established PALs have been accepted by the regulatory agency for use. 
The comparison of laboratory results to PALs will be discussed in the CADD. Laboratory results above PALs indicate the presence of COCs that will require further evaluation. The evaluation of potential corrective actions and the justification for a preferred action will be included in the CADD based on the results of this field investigation. Proposed clean-up levels will be presented in the CADD, if applicable.

\subsubsection{Field-Screening Levels}

Field screening may be instituted to assist in providing additional semiquantitative measurements. The field-screening results (FSRs), along with other biasing factors, may help guide the selection of the most appropriate sampling location for collection of laboratory samples. The following action levels may be used for on-site field screening:

- Headspace field screening for VOC headspace screening levels at 20 ppm or 2.5 times background, whichever is greater

- $\quad$ TPH field-screening results greater than 75 ppm measured using an appropriate field-screening method (e.g., gas chromatography or an equivalent method)

- Radiological (alpha and beta/gamma) field-screening level (FSL) for soil samples is the mean background activity plus two times the standard deviation of the mean background activity

Field-screening concentrations exceeding FSLs indicate potential contamination at that sample location. This information will be documented and the investigation will be continued in order to delineate the extent of contamination. Additionally, this data may also be used to select samples to be submitted for laboratory analysis.

\subsection{Data Quality Objectives Process Discussion}

This section contain a summary of the DQO process that is presented in Appendix A.1. The DQO process is a strategic planning approach based on the scientific method that is used to prepare for site characterization data collection. The DQOs are designed to ensure that the data collected will provide sufficient and reliable information to identify, evaluate, and technically defend the recommendations of viable corrective actions, (e.g., no further action, closure in place, or clean closure). 
The DQO strategy for CAU 543 was developed at a meeting on February 26, 2004. The DQOs were developed to identify data needs, clearly define the intended use of the environmental data, and to design a data collection program that will satisfy these purposes. During the DQO discussions for this CAU, the informational inputs of data needs to resolve problem and decision statements were documented. Details of the DQO process are presented in Appendix A.1.

The problem statement for CAU 543 is: "Existing information on the nature and extent of potential contamination is insufficient to evaluate and recommend corrective action alternatives for the CASs in CAU 543." To address this question, the resolution of two decision statements is required:

- Decision I: "Is any COC present in environmental media within the CAS at a concentration that could pose an unacceptable risk to human health and the environment?"

- Decision II: "If a COC is present, is sufficient information available to evaluate appropriate corrective action alternatives?"

Decision I samples will be submitted for the analytical methods listed in Table 3-3 and Table 3-4 and the Decision II samples may be a subset of the analytes identified in Table 3-2.

In addition, data will be collected to support waste management decisions.

The analytical methods and reporting limits prescribed through the DQO process, as well as the DQIs for laboratory analysis such as precision and accuracy requirements, are provided in more detail in Section 6.0. Laboratory data will be assessed to confirm or refute the CSM and determine if the DQOs were met based on the DQIs of precision, accuracy, representativeness, completeness, and comparability. Other DQIs, such as sensitivity, may be used.

Analytical methods and minimum reporting limits (MRLs) for each chemical parameter are provided in Table 3-4. The MRL is a practical reporting limit that ensures data generated by the laboratory will be usable by the investigation.

Radiation MRLs were developed considering both the MDCs and the PALs (Adams and Dionne, 2000). The minimum detectable concentrations (MDCs), PALs, and MRLs for radionuclides are provided in Table 3-3. The MDC is the lowest concentration of a particular parameter that can be detected in a sample with an acceptable level of error. The MDCs listed in Table 3-3 are typical default levels available for a commercial radioanalytical laboratory. 
Table 3-3

Analytical Requirements for Radionuclides for CAU 543

\begin{tabular}{|c|c|c|c|c|c|c|}
\hline Parameter/Analyte & Matrix & $\begin{array}{l}\text { Analytical } \\
\text { Method }\end{array}$ & $M C^{a}$ & $\mathrm{PAL}^{\mathrm{b}, \mathrm{c}}$ & $\begin{array}{l}\text { Laboratory } \\
\text { Precision }\end{array}$ & Percent Recovery \\
\hline \multicolumn{7}{|c|}{ Gamma Spectroscopy } \\
\hline \multirow{2}{*}{ Americium-241 } & water & EPA 901.1 ${ }^{\mathrm{d}}$ & $50 \mathrm{pCi} / \mathrm{L}^{\mathrm{e}}$ & $50 \mathrm{pCi} / \mathrm{L}$ & \multirow{3}{*}{$\begin{array}{c}\text { Relative Percent } \\
\text { Difference (RPD) } \\
20 \% \text { water } 35 \% \text { Soil }\end{array}$} & \multirow{4}{*}{$\begin{array}{c}\text { Laboratory Control } \\
\text { Sample Recovery } \\
80-120^{\mathrm{h}} \text { Percent } \\
\text { Recovery }(\% \mathrm{R})\end{array}$} \\
\hline & soil & $\mathrm{HASL}^{-300^{\top}}$ & $2.0 \mathrm{pCi} / \mathrm{g}^{\mathrm{e}}$ & $7.62 \mathrm{pCi} / \mathrm{g}$ & & \\
\hline \multirow[b]{2}{*}{ Cesium-137 } & water & EPA $901.1^{\text {d }}$ & $10 \mathrm{pCi} / \mathrm{L}^{\mathrm{e}}$ & $10 \mathrm{pCi} / \mathrm{L}$ & & \\
\hline & soil & HASL- $300^{f}$ & $0.5 \mathrm{pCi} / \mathrm{g}^{\mathrm{e}}$ & $7.3 \mathrm{pCi} / \mathrm{g}$ & $\begin{array}{l}\text { Normalized } \\
\text { Difference } \\
-2<N D<2^{9}\end{array}$ & \\
\hline \multicolumn{7}{|c|}{ Other Radionuclides } \\
\hline \multirow{2}{*}{ Plutonium-238 } & water & $\begin{array}{c}\text { ASTM } \\
\text { D3865-02 }\end{array}$ & $0.1 \mathrm{pCi} / \mathrm{L}$ & $0.16 \mathrm{pCi} / \mathrm{L}$ & \multirow{12}{*}{$\begin{array}{c}\text { Relative Percent } \\
\text { Difference (RPD) } \\
20 \% \text { water } 35 \% \text { Soil }\end{array}$} & \multirow{12}{*}{$\begin{array}{c}\text { Laboratory Control } \\
\text { Sample Recovery } \\
80-120^{\mathrm{h}} \text { Percent } \\
\text { Recovery (\%R) } \\
\text { Chemical Yield } 30-105^{\mathrm{j}} \\
\text { \%R }\end{array}$} \\
\hline & soil & $\begin{array}{c}\text { ASTM } \\
\text { C1001-00k }\end{array}$ & $0.05 \mathrm{pCi} / \mathrm{g}$ & $7.78 \mathrm{pCi} / \mathrm{g}$ & & \\
\hline \multirow{2}{*}{ Plutonium-239/240 } & water & $\begin{array}{c}\text { ASTM } \\
\text { D3865-02 }\end{array}$ & $0.1 \mathrm{pCi} / \mathrm{L}$ & $0.1 \mathrm{pCi} / \mathrm{L}$ & & \\
\hline & soil & $\begin{array}{c}\text { ASTM } \\
\text { C1001-00k }\end{array}$ & $0.05 \mathrm{pCi} / \mathrm{g}$ & $7.62 \mathrm{pCi} / \mathrm{g}$ & & \\
\hline \multirow[t]{2}{*}{ Strontium-90 } & water & $\begin{array}{c}\text { ASTM } \\
\text { D5811-00 }\end{array}$ & $1.0 \mathrm{pCi} / \mathrm{L}$ & $1.0 \mathrm{pCi} / \mathrm{L}$ & & \\
\hline & soil & HASL $300^{\dagger}$ & $0.5 \mathrm{pCi} / \mathrm{g}$ & $503.0 \mathrm{pCi} / \mathrm{g}$ & & \\
\hline \multirow[t]{2}{*}{ Uranium-234 } & water & $\begin{array}{c}\text { ASTM } \\
\text { D3972-02' }\end{array}$ & $0.1 \mathrm{pCi} / \mathrm{L}$ & $0.1 \mathrm{pCi} / \mathrm{L}$ & & \\
\hline & soil & $\mathrm{C} 1000-02^{\mathrm{m}}$ & $0.05 \mathrm{pCi} / \mathrm{g}$ & $85.9 \mathrm{pCi} / \mathrm{g}$ & & \\
\hline \multirow{2}{*}{ Uranium-235 } & water & $\begin{array}{c}\text { ASTM } \\
\text { D3972-02 }\end{array}$ & $0.1 \mathrm{pCi} / \mathrm{L}$ & $0.1 \mathrm{pCi} / \mathrm{L}$ & & \\
\hline & soil & $\mathrm{C} 1000-02^{\mathrm{m}}$ & $0.05 \mathrm{pCi} / \mathrm{g}$ & $10.5 \mathrm{pCi} / \mathrm{g}$ & & \\
\hline \multirow{2}{*}{ Uranium-238 } & water & $\begin{array}{c}\text { ASTM } \\
\text { D3972-02 }\end{array}$ & $0.1 \mathrm{pCi} / \mathrm{L}$ & $9.39 \mathrm{pCi} / \mathrm{L}$ & & \\
\hline & soil & $\mathrm{C} 1000-02^{\mathrm{m}}$ & $0.05 \mathrm{pCi} / \mathrm{g}$ & $63.2 \mathrm{pCi} / \mathrm{g}$ & & \\
\hline
\end{tabular}

${ }^{a}$ The MDC is the lowest concentration of a radionuclide, if present in a sample, that can be detected with a 95 percent confidence level.

'The PALs for soil are based on the National Council on Radiation Protection and Measurement (NCRP) Report No. 129

"Recommended Screening Limits for Contaminated Surface Soil and Review of Factors Relevant to Site-Specific Studies" (NCRP,

1999) scaled from 25 to $15 \mathrm{mrem} / \mathrm{yr}$ dose and the guidelines for residual concentration of radionuclides in DOE Order 5400.5

(DOE, 1993).

${ }^{\mathrm{c}}$ The PALs for liquids are set equal to the MDC.

${ }^{\mathrm{d}}$ Prescribed Procedures for Measurements of Radioactivity in Drinking Water, EPA-600/4-80-032 (EPA, 1980)

${ }^{\mathrm{e}} \mathrm{MDCs}$ vary depending on the presence of other gamma-emitting radionuclides in the sample and are relative to the MDC for Cs-137.

${ }^{\mathrm{f} E n v i r o n m e n t a l}$ Measurements Laboratory Procedures Manual, HASL-300 (DOE, 1997)

${ }^{9} \mathrm{ND}$ is not RPD, it is another measure of precision used to evaluate duplicate analyses. The ND is calculated as the difference between two results divided by the square root of the sum of the squares of their total propagated uncertainties. Evaluation of Radiochemical Data Usability (Paar and Porterfield, 1997)

'EPA Contract Laboratory Program Statement of Work for Inorganic Analysis (EPA, 1988a; 1994b; and 1995)

iStandard Test Method for Plutonium in Water (ASTM, 2002b)

jGeneral Radiochemistry and Routine Analytical Services Protocol (GRASP) (EG\&G Rocky Flats, 1991). The chemical yield only applies to plutonium, uranium, and strontium.

${ }^{k}$ Standard Test Method for Radiochemical Determination of Plutonium in Soil by Alpha Spectroscopy (ASTM, 2000a)

'Standard Test Method for Isotopic Uranium in Water by Radiochemistry (ASTM, 2002a)

m Standard Test Method for Radiochemical Determination of Uranium Isotopes in Soil by Alpha Spectrometry (ASTM, 2002c)

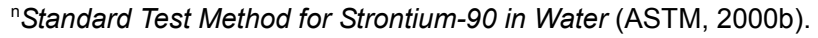

ASTM = American Society for Testing and Materials $M R L=$ Minimum reporting limit

$\mathrm{ND}=$ Normalized difference

$\mathrm{pCi} / \mathrm{L}=$ Picocuries per liter
MDC = Minimum detectable concentration

$\mathrm{PAL}=$ Preliminary action level

$\mathrm{pCi} / \mathrm{g}=$ Picocuries per gram 
Table 3-4

Analytical Requirements for Nonradiological Analytes for CAU 543*

(Page 1 of 3 )

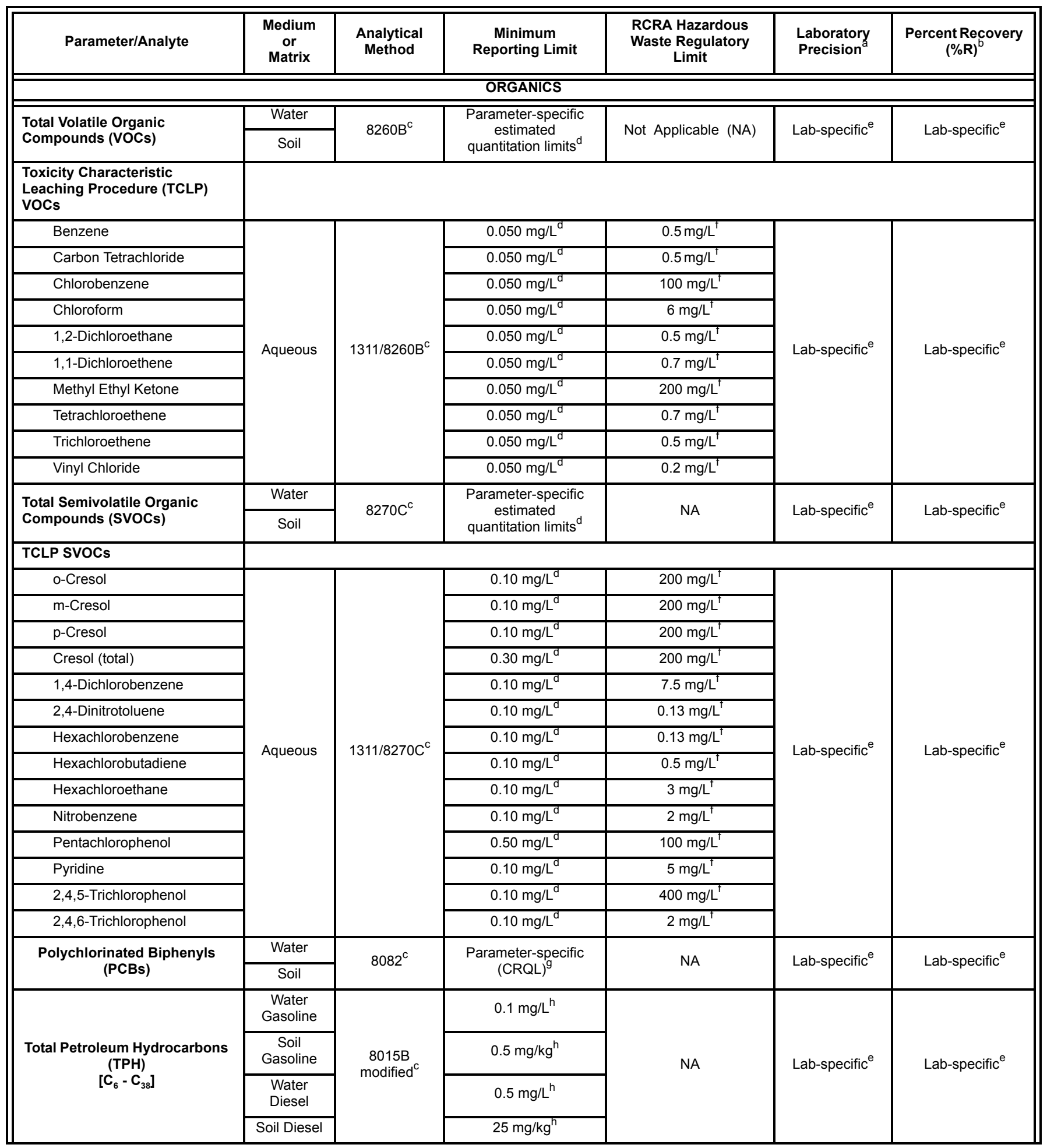




\section{Table 3-4 \\ Analytical Requirements for Nonradiological Analytes for CAU 543*}

(Page 2 of 3 )

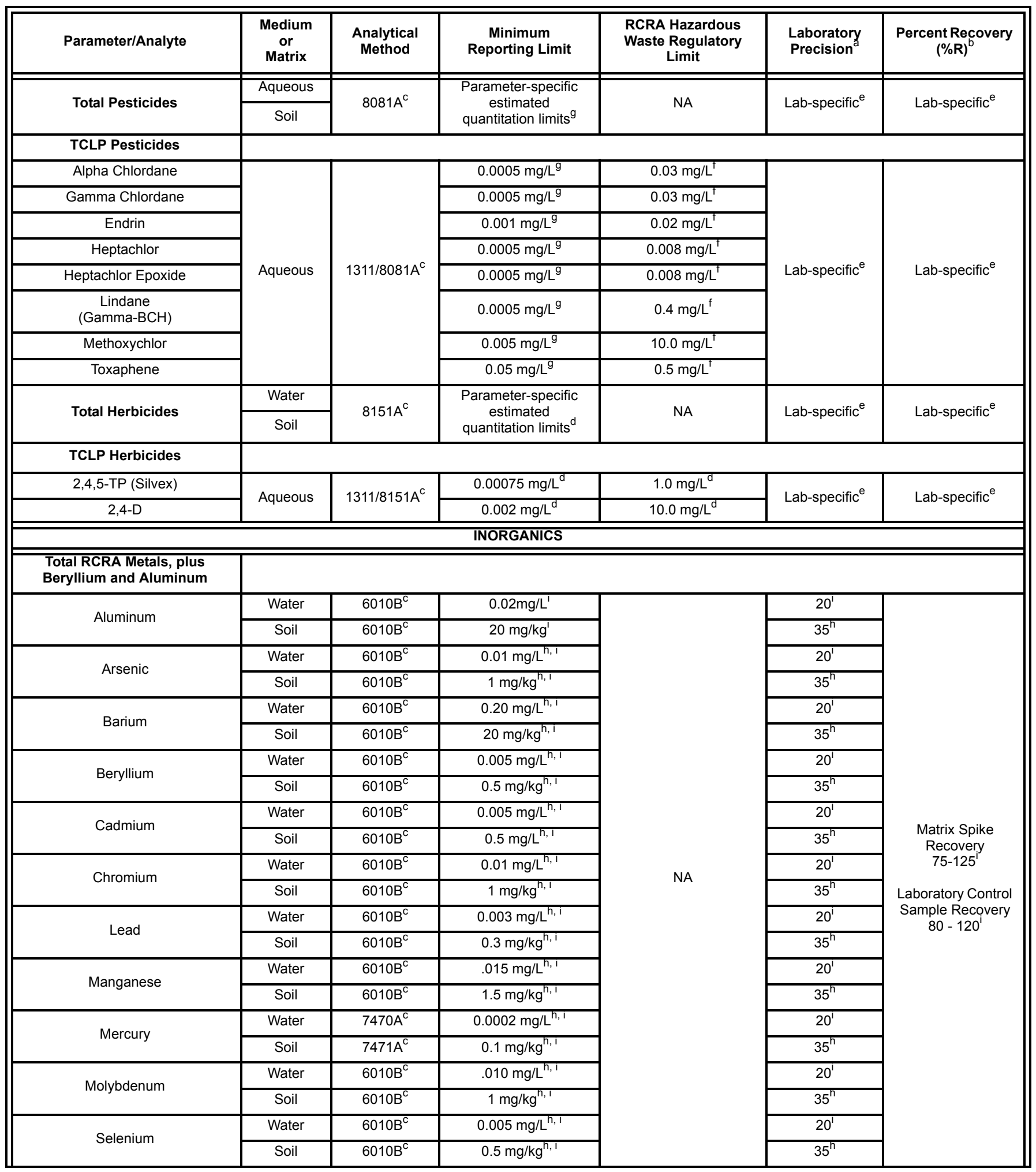




\section{Analytical Requirements for Nonradiological Analytes for CAU 543* (Page 3 of 3 )}

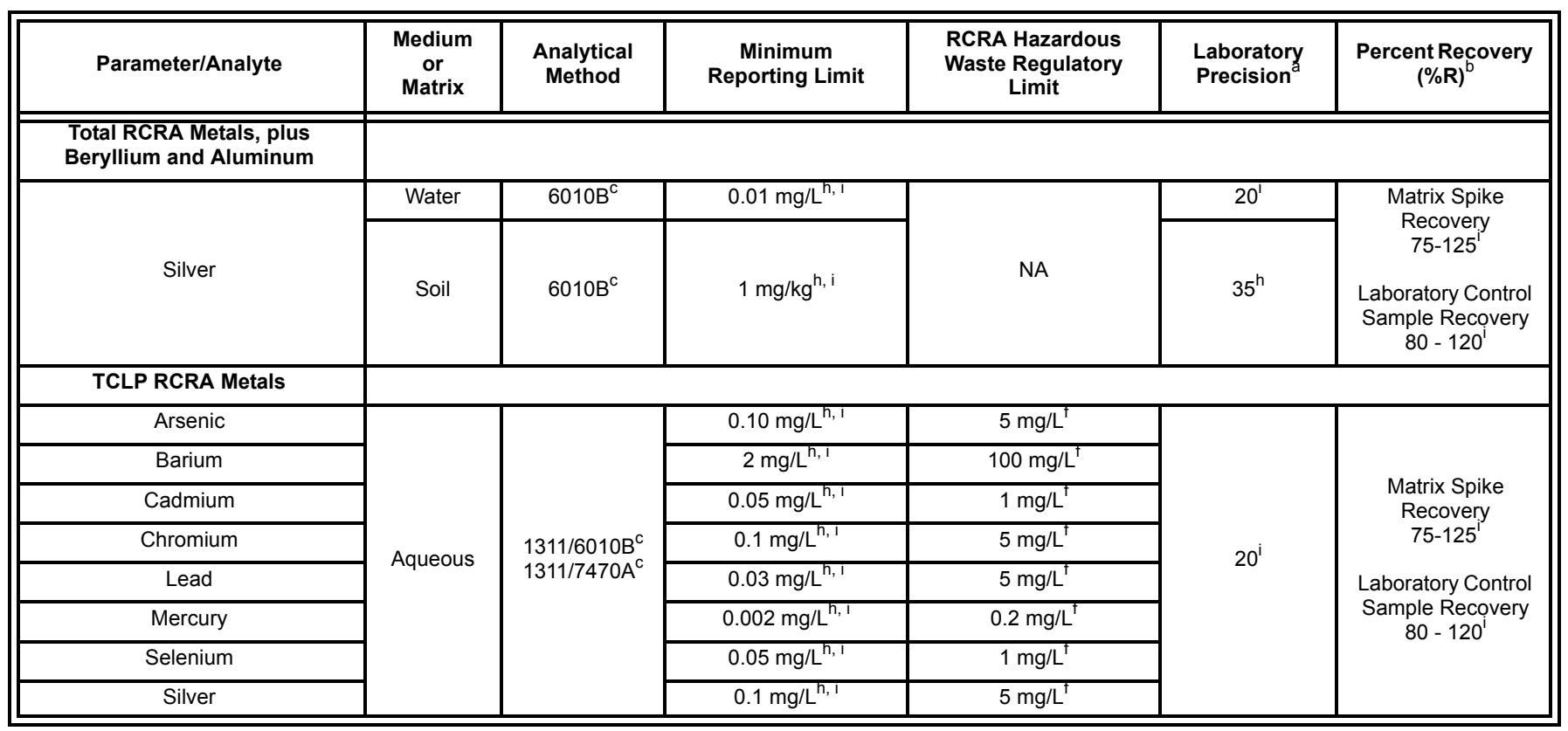

*Footnotes:

1. See Table 3-3 for the analytical requirements for radionuclides.

2. See Table 4-1 for the analyses of geotechnical and hydrological properties.

${ }^{a}$ Relative percent difference (RPD) is used to calculate precision. Precision is estimated from the RPD of the concentrations measured for the matrix spike and matrix spike duplicate or of laboratory, or field duplicates of unspiked samples. It is calculated by: $R P D=100 \times\left\{\left(\left|A_{1}-A_{2}\right|\right) /\left[\left(A_{1}+A_{2}\right) / 2\right]\right\}$, where $A_{1}=C o n c e n t r a t i o n$ of the parameter in the initial sample aliquot, $A_{2}=$ Concentration of the parameter in the duplicate sample aliquot.

${ }^{b}$ The $\% R$ is used to calculate accuracy. Accuracy is assessed from the recovery of parameters spiked into a blank or sample matrix of interest, or from the recovery of surrogate compounds spiked into each sample. The recovery of each spiked parameter is calculated by: $\% R=100 \times\left(A_{s}-A_{u} / A_{n}\right)$, where $A_{s}=$ Concentration of the parameter in the spiked sample, $A_{u}=$ Concentration of the parameter in the unspiked sample, $A_{n}=$ Concentration increase that should result from spiking the sample.

c The EPA Test Methods for Evaluating Solid Waste Physical/Chemical Methods, 3rd Edition, Parts 1-4, (SW-846) CD ROM, Washington, DC (EPA,1996).

dEstimated Quantitation Limit as given in SW-846 (EPA, 1996).

${ }^{\mathrm{e}}$ In-House Generated RPD and \%R Performance Criteria. It is necessary for laboratories to develop in-house performance criteria and compare them to those in the methods. The laboratory begins by analyzing 15 to 20 samples of each matrix and calculating the mean \%R for each parameter. The standard deviation (SD) of each $\% R$ is then calculated, and the warning and control limits for each parameter are established at \pm 2 SD and \pm 3 SD from the mean, respectively. If the warning limit is exceeded during the analysis of any sample delivery group (SDG), the laboratory institutes corrective action to bring the analytical system back into control. If the control limit is exceeded, the sample results for that SDG are considered unacceptable. These limits are reviewed after every quarter and are updated when necessary. The laboratory tracks trends in both performance and control limits by the use of control charts. The laboratory's compliance with these requirements is confirmed as part of an annual laboratory audit. Similar procedures are followed in order to generate acceptance criteria for precision measurements.

f Title 40 Code of Federal Regulations (CFR) Part 261, "Identification and Listing of Hazardous Waste" (CFR, 2002a)

9 EPA Contract Laboratory Program (CLP) Statement of Work for Organic Analysis (EPA, 1988b; 1991; and 1994c)

h Industrial Sites Quality Assurance Project Plan (NNSA/NV, 2002)

'EPA Contract Laboratory Program Statement of Work for Inorganic Analysis (EPA, 1988a; 1994b; and 1995)

Definitions:

$\mathrm{mg} / \mathrm{L}=$ Milligrams per liter

$\mathrm{mg} / \mathrm{kg}=$ Milligrams per kilogram

$\mathrm{CRQL}=$ Contract-required quantitative limits 


\subsection{Field Investigation}

This section contains the technical approach for the CAU 543 field investigation.

\subsection{Technical Approach}

The information necessary to resolve the DQO decisions will be generated for each CAU 543 CAS by collecting and analyzing samples generated during a field investigation. The presence and nature of contamination at each CAS will be evaluated by collecting samples at biased locations that are determined to be most probable to contain COCs if they are present anywhere within the CAS. These locations will be determined based on the identification of biasing factors. Additional random samples will also be collected at CASs 15-23-01 and the contamination area component of CAS 06-07-01 since the CAS footprints are large and biasing factors may not be present to adequately locate contamination. If, while defining the nature of contamination, it is determined that COCs are present at a CAS, that CAS will be further addressed by determining the extent of contamination before evaluating corrective action alternatives.

Sample locations may be changed based on site conditions, obvious debris or staining of soils, FSRs, or professional judgement. The Site Supervisor has the discretion to modify the biased locations, but only if the modified locations meet the DQO decision needs and criteria stipulated in Appendix A.1.

Since this CAIP only addresses contamination originating from the CAU, it may be necessary to distinguish overlapping contamination originating from other sources. For example, widespread surface radiological contamination originating from atmospheric tests will not be addressed under CAU 543. To determine if contamination is from the CAU or from other sources, soil samples may be collected from background locations at selected CASs.

Modifications to the investigative strategy may be required should unexpected field conditions be encountered at any CAS. Significant modifications shall be justified, approved, and documented on a Record of Technical Change (ROTC). The ROTC is required prior to proceeding with the investigation activities significantly different from those described in this document. If an unexpected condition indicates that conditions are significantly different than the corresponding CSM, the activity may be rescoped and the identified decision makers will be notified. 
Decision I and II soil samples will be collected at selected locations using various drilling methods (e.g., rotary sonic, hollow-stem auger, or other applicable methods), direct-push, hand/power auger, hand tools, and/or excavation, as appropriate. Table 3-2 provides the analytical parameters to be used when analyzing for the COPCs identified for each CAS. Table 3-3 and Table 3-4 provide the analytical requirements to be followed during this CAI. All sampling and QC requirements for field and laboratory environmental sampling will be conducted in compliance with the Industrial Sites QAPP (NNSA/NV, 2002a) and other applicable procedures. A current version of the Environmental Services Architect-Engineer Contractor's Health and Safety Plan (HASP) will accompany the field documents, and a SSHASP, or equivalent will be prepared and approved prior to the field effort.

\subsection{Field Activities}

Activities to be conducted under this CAIP include:

- Relocate surface debris, equipment, and structures as necessary to allow access to sampling locations.

- Perform visual surveys at all CASs to identify biasing factors

- Perform video-mole surveys of system piping and components for residual sediment and breaches in the piping

- Inspect all tanks (e.g., AST, dip tanks, and septic tanks) for residual materials

- Inspect the ground surface beneath and immediately surrounding the PSP at CAS 15-23-01 to identify if dry well is present

- $\quad$ Perform field screening for applicable COPCs

- Collect and analyze samples from random and biased locations as described in this section.

- Collect required QC samples

- Collect additional samples, as necessary, to support the characterization of IDW and potential corrective action waste streams (i.e., tank contents)

- Perform radiological characterization surveys (including swipe collection and analysis)

- Collect and analyze samples for geotechnical and hydrological parameters, if appropriate 
- Collect and analyze bioassessment samples if appropriate (e.g., if VOC concentrations exceed field-screening levels in a pattern that suggests a plume may be present)

- Stake or flag sample locations and record coordinates

\subsubsection{Site Preparation Activities}

Site preparation may be required by the NTS Management and Operating (M\&O) Contractor prior to the investigation. Site preparation may include, but not be limited to: providing access to sampling points (e.g., fence removal), the construction of hazardous waste accumulation areas (HWAAs) and site exclusion zones, removal and proper disposal of surface debris, and temporarily moving staged equipment.

\subsubsection{Decision I Activities}

The objective of the Decision I strategy is to determine the presence and nature of COCs within the CAU boundary. The Decision I sampling strategy targets locations and media most likely to be contaminated by migrating COCs. The initial Decision I activities planned for CAU 543 include visual inspections, video-mole surveys, field screening, and biased and random soil sampling and analysis. The presence of COCs will be determined by random and biased sampling and laboratory analyses. A comparison of laboratory analytical results from Decision I samples to PALs will be used to confirm the presence or absence of COCs.

Appendix A.1 lists the target populations for Decision I and identifies information needs in selecting data collection locations to determine the nature and extent of contamination. Biasing factors will be used to select the most appropriate sample locations and field screening will be used to select the most appropriate samples from a particular location for submittal to the analytical laboratory. Biasing factors to be used for selection of sampling locations will include the following:

- Documented process knowledge on source and location of release

- Visual evidence of discoloration, textural discontinuities, disturbance of native soils, or any other indication of potential contamination

- Presence of debris or equipment

- Presence of elevated areas based on the results of radiological surveys 
- Field-screening results

- Previous sample or screening results

- Experience and data from investigations of similar sites

As biasing factors are identified and used for selection of sampling locations, they will be documented in the appropriate field documents. Field screening, along with these other biasing factors, may help guide the selection of the most appropriate sampling location for collection of laboratory samples. The FSLs established for the field-screening methods that may be used for on-site field screening are provided in Section A.1.4.3 in Appendix A.1.

Random sampling locations will be determined in accordance with the DQO process for the investigation of CAS 15-23-01 (Underground Radioactive Materials Area) and the "Contamination Area" component of CAS 06-07-01. Approved statistical methods defined in Chapter 9 of EPA SW-846 were used to arrive at the minimum number of samples required to ensure a 90 percent confidence level in the COPC concentration (EPA, 1996). These numbers were input in to the VSP random sampling location generating software (PNNL, 2002) in order to produce an example of proposed sampling locations, as presented in Figure 4-3 and Figure 4-9. Examples of the selection of randomized sampling locations for each CAS and the use of the VSP software are described in Appendix A.3.

For the CASs or CAS components of CAU 543 that include septic tanks, distribution boxes, USTs, and ASTs, the initial visual inspection will include accessing and opening tanks to document details on the tank contents. The tank contents will be sampled for waste characterization purposes, if present and accessible. If separate phases are identified, and if possible, a sample of each phase will be collected for analysis. Based on the results of the radiological survey of the concrete surfaces of decontamination pads and sumps, swipes may be collected and analyzed on site for removable radiological contaminants. Based on biasing factors, scabbling of the concrete may be conducted to collect samples for off-site analysis of chemical and/or radiological contaminants.

Most of the Area 15 EPA Farm CASs and components of CAS 06-07-01 have elements of an effluent collection and distribution system that involves subsurface piping. At these areas a video-mole survey will be conducted prior to Decision I sampling from within the associated piping to identify 
residual material, breaches, or unknown tie-ins. Site conditions and conditions of the piping may not allow a 100 percent video survey. If the video survey identifies breaches and/or conditions that may have provided a means for effluent to reach the surrounding soils, then Decision I samples may be collected at those locations for laboratory analysis. If residual material is present and of an adequate volume, a sample will be collected for analysis. If no breaches or residual effluent is identified during the survey, than Decision I sampling adjacent to and within the buried portions of the pipelines will not be necessary. Sections of piping that are breached to gain access for inspection and/or sampling, will be grouted upon completion of these activities.

Decision I surface soil samples ( 0 to $0.5 \mathrm{ft}$ bgs) will be collected from selected locations based on the biasing factors listed above. For subsurface features (e.g., septic tanks), Decision I subsurface soil samples will be collected from selected locations at the junctions (i.e., inlet pipe) and base of the feature or deeper. The estimated depth of subsurface features will be determined by engineering drawings and other historical documentation. If biasing factors are present in soils below where Decision I biased and/or random samples were removed, additional Decision I soil samples will be collected at depth by hand augering, backhoe excavation, direct-push, or drilling techniques, as appropriate. Sample intervals will be selected by the Site Supervisor based on biasing factors to a depth where the biasing factors are no longer present.

\subsubsection{Decision II Activities}

Decision II sampling will consist of further characterizing sites to define the extent of contamination where COCs have been confirmed or are suspected to be present. Step-out (Decision II) sampling locations at each CAS will be selected based on the outer boundary sample locations where COCs were detected in the Decision I soil samples. Decision II locations will also be selected based on the elements of the CSM and other biasing factors listed in Section 4.2.2. In general, step-out sample locations will be arranged in a triangular pattern around the Decision I location at distances based on site conditions, process knowledge, and biasing factors. If COCs extend beyond the initial step-outs, Decision II samples will be collected from incremental step-outs. At each step-out location, screening samples will be collected at the maximum depth where COCs were encountered and from two additional depth intervals. If the FSRs are not greater than FSLs, one of these samples (typically the uppermost) will be submitted to the laboratory for analysis. A minimum of one clean sample 
(i.e., COCs less than PALs) will be collected from each lateral and vertical direction and submitted for laboratory analysis to define the extent of COC contamination. The lateral and vertical extent of COCs will be established based on validated laboratory analytical results (i.e., not field screening). The number, location, and spacing of step-outs may be modified by the Site Supervisor, as warranted by site conditions. This sampling approach is designed to bound the COCs both vertically and horizontally. Contaminants determined not to be present in Decision I samples may be eliminated from Decision II analytical suites.

The spatial boundaries that apply to each CAS for Decision II are defined in Table A.1-6. If the nature and/or extent of contamination is inconsistent with the CSM or if contamination extends beyond the spatial boundaries identified in Table A.1-6, work will be temporarily suspended, NDEP will be notified, and the investigation strategy will be reevaluated. As long as contamination is consistent with the CSM, sampling will continue to define extent.

\subsubsection{CAS-Specific Activities}

The following outlines the CAS-specific activities for the CAI of CAU 543.

\subsubsection{CAS 06-07-01, Decon Pad}

The detailed investigation strategy for the Area 6 Decontamination Facility will be discussed based on the various components of the CAS including: effluent collection system, decontamination pads, Building 6-605, and the Contamination Area.

Effluent Collection/Distribution System - Prior to Decision I sampling, a video-mole survey will be performed on as much of the subsurface piping as practical to identify breaks, residual materials, and location of sumps/tanks. Excavation may be performed to locate the subsurface sumps and septic tanks. If any breaches are identified within the piping, excavation and Decision I subsurface soil sampling will be implemented. Additional Decision I soil sampling will be performed at the junctions of subsurface piping at Sump 1, Sump 2, and the two septic tanks associated with Buildings 6-605 and 6-607 assuming all these components are still present. Decision I soil samples will be collected near the base of the sumps and septic tanks to capture potential leaks. Decision I samples 
will be collected on any residual sediments or liquids identified in the piping, sumps, and septic tanks for waste management purposes. See Figure 4-1 for proposed sample locations.

Decontamination Pads - Decision I soil samples will be collected from the surface soils surrounding the edges of the outdoor concrete pads adjacent to Buildings 6-605 and 6-606 to capture potential contaminated run-off. The concrete will be scabbled at visibly stained areas and concrete samples will be collected for Decision I analysis. Decision I samples will be collected from any residual sediment still remaining within the pad trench or floor drains. Figure 4-1 shows the proposed sample locations.

Building 6-605 - Decision I sample and survey data collection will be implemented for components and building materials within Building 6-605 to determine future waste disposal actions if demolition and disposal of the building is chosen as a corrective action. All drains, trenches, and piping associated with both the sanitary and process-waste systems will be inspected for remaining residual sediments/materials. If residual material is present in adequate volume, Decision I samples will be collected. If biasing factors indicate the need, concrete within the building floors may be scabbled and sampled for analysis. The remaining caustic dip tanks will be accessed and inspected for residual materials. Any remaining liquids and/or solids present may be collected for Decision I sample analysis.

Radiological surveys (i.e., scanning, static, and swipe collection) may be conducted during Decision I on interior and exterior building components to determine the relative nature and extent of radiological contamination. Based on the significance of the identified contamination, coupons (i.e., building component media) may be collected for sampling to refine the nature and extent of radiological and chemical contamination.

It is expected that the nature of Decision I sampling and surveys will most likely provide sufficient information on the extent of contamination for Building 6-605 so that remobilization for Decision II data collection may not be necessary. See Figure 4-2 for proposed sample locations.

Building materials moved or altered during the investigation of Building 6-605 (e.g., piping fixtures) for the purposes of accessing confined areas for assessment, survey, or sample collection will not be 


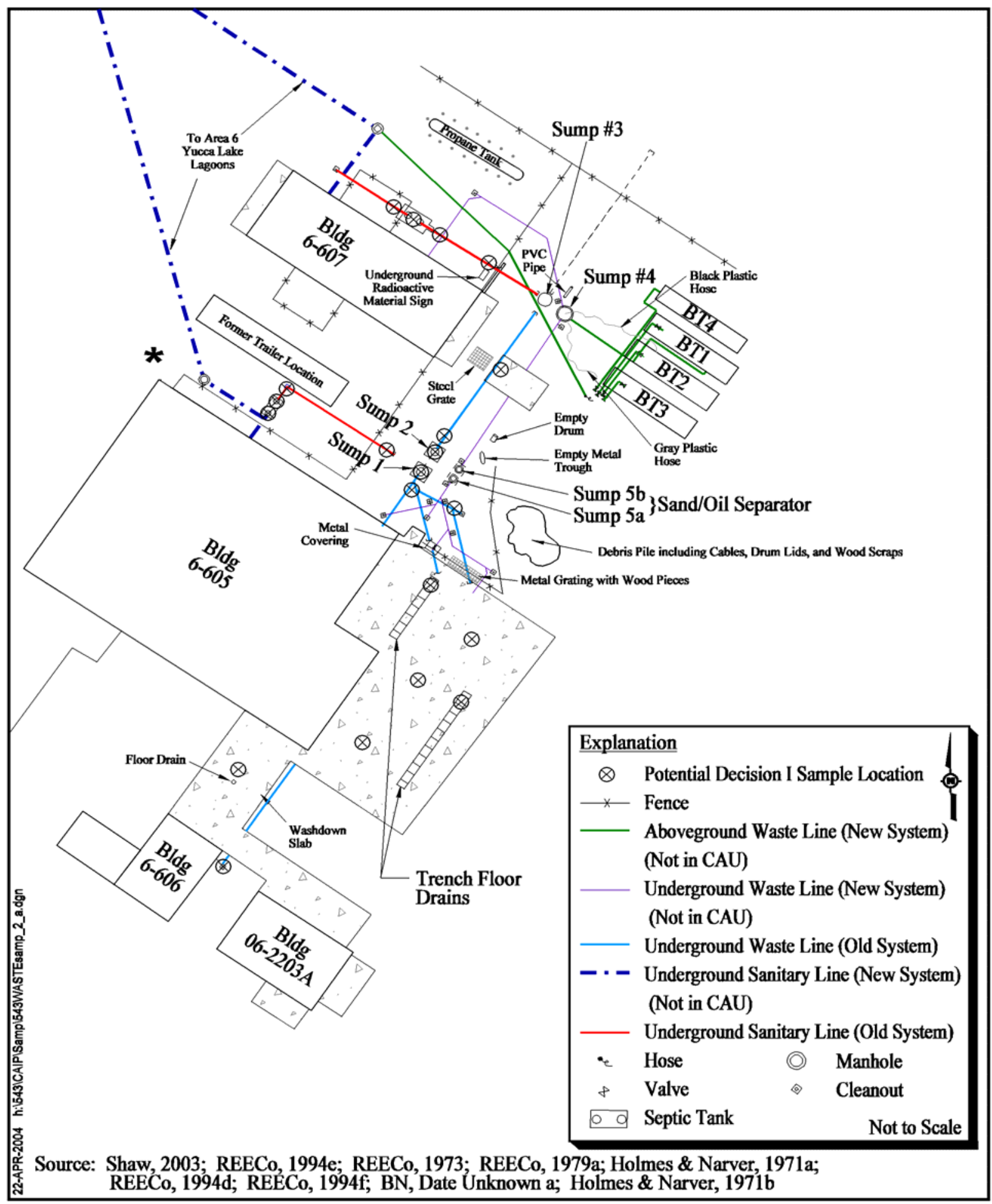

Figure 4-1

CAU 543, CAS 06-07-01, Decon Pad, Septic System, and Piping Proposed Decision I Sample Locations 


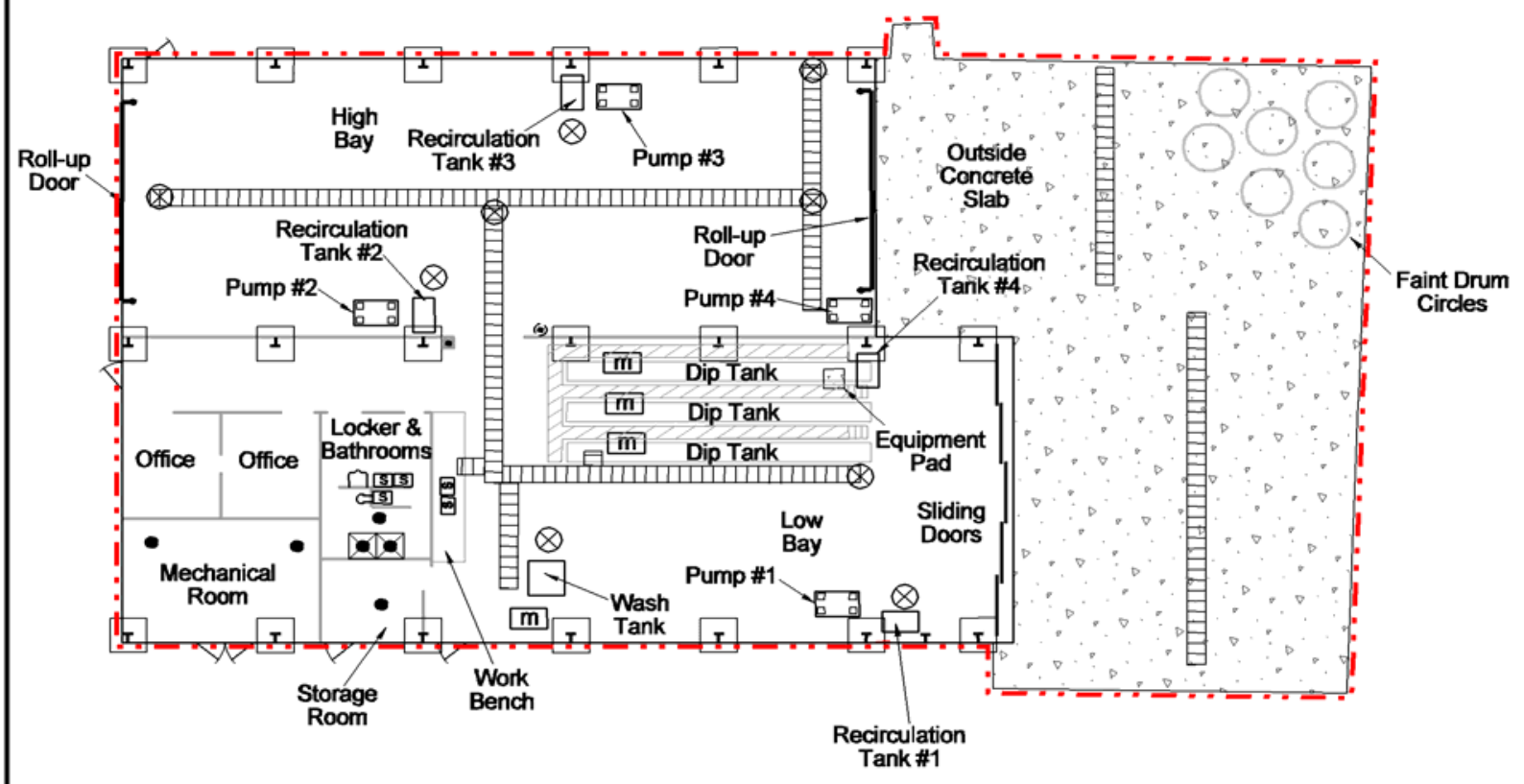

Explanation

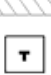

$\mathbf{T}$

- Door

3 Pipe and Flange

피마 Trench Floor Drain $\bowtie \quad$ Shower
- Floor Drain

(2) Sink

$c$ Toilet

i) Urinal

m Motor

- Drinking Fountain

\section{- - Section of CAS 06-07-01 Footprint}

Q Potential Decision I

Sampling Location

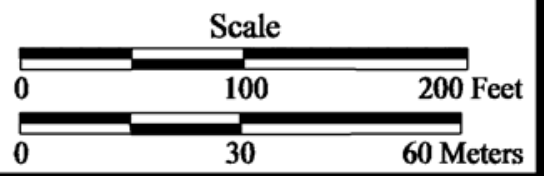

Source: REECo, 1979b; REECo, 1979c; REECo, 1979d; REECo, 1979e; REECo, 1985; REECo, 1994a; REECo, 1994b; REECo, 1994c; BN, 1998; REECo, 1973; and Shaw, 2003

Figure 4-2

CAU 543, CAS 06-07-01, Potential Decision I Sample Locations 
considered IDW. These materials will be returned to their original location, if possible, and addressed during the demolition and disposal of the building.

Contamination Area - A statistical based and biased sampling approach will be implemented during Decision I sampling of the surface soils within the area designated as the Contamination Area. A total of 16 random surface samples has been determined sufficient to satisfy the criteria of a 90 percent confidence level in the COPC concentration as determined by the methodology defined in Chapter 9 of EPA SW-846. The 16 sample locations have been randomly generated using the VSP program and will be within the boundary of the Contamination Area. Figure 4-3 shows the proposed surface soil sample locations. Additional biased samples may be collected where deemed appropriate.

Decision II sampling will be conducted to define the extent of contamination at the CAS components where Decision I samples indicate and/or confirm the presence of COCs, as described in Section 4.2.3.

\subsubsection{Area 15 EPA Farm}

Discussions of the detailed investigation strategy for the Area 15 EPA Farm will be grouped based on related or similar CASs including septic system and leachfield (CASs 15-04-01 and 15-05-01); liquid manure UST and concrete pad (15-08-01); the contaminated sump and AST (CASs 15-23-03 and 15-01-03); and the decontamination area (CAS 15-23-01).

\section{CASs 15-04-01 and 15-05-01, Septic Tank and Leachfield System}

Prior to Decision I sampling, a video-mole survey will be performed to identify residual materials, breaches, location of the septic tank if still present, and the end of distribution lines. Excavation will be performed to access and inspect the septic tank and distribution box for integrity. Decision I soil sampling will be conducted below the septic tank inlet and outlet, the outlet from Building 15-06, the distribution box inlet/outlet, below the tank and box, and locations of identified breaches within any part of the system. Decision I activities at the leachfield will consist of excavating to locate the boundaries of the leachfield, exposing the midpoint, and the proximal and distal ends of the associated perforated distribution pipes, and collecting biased samples from soil beneath the leachrock/native soil interface at the midpoint, and proximal and distal ends of the distribution pipes. 


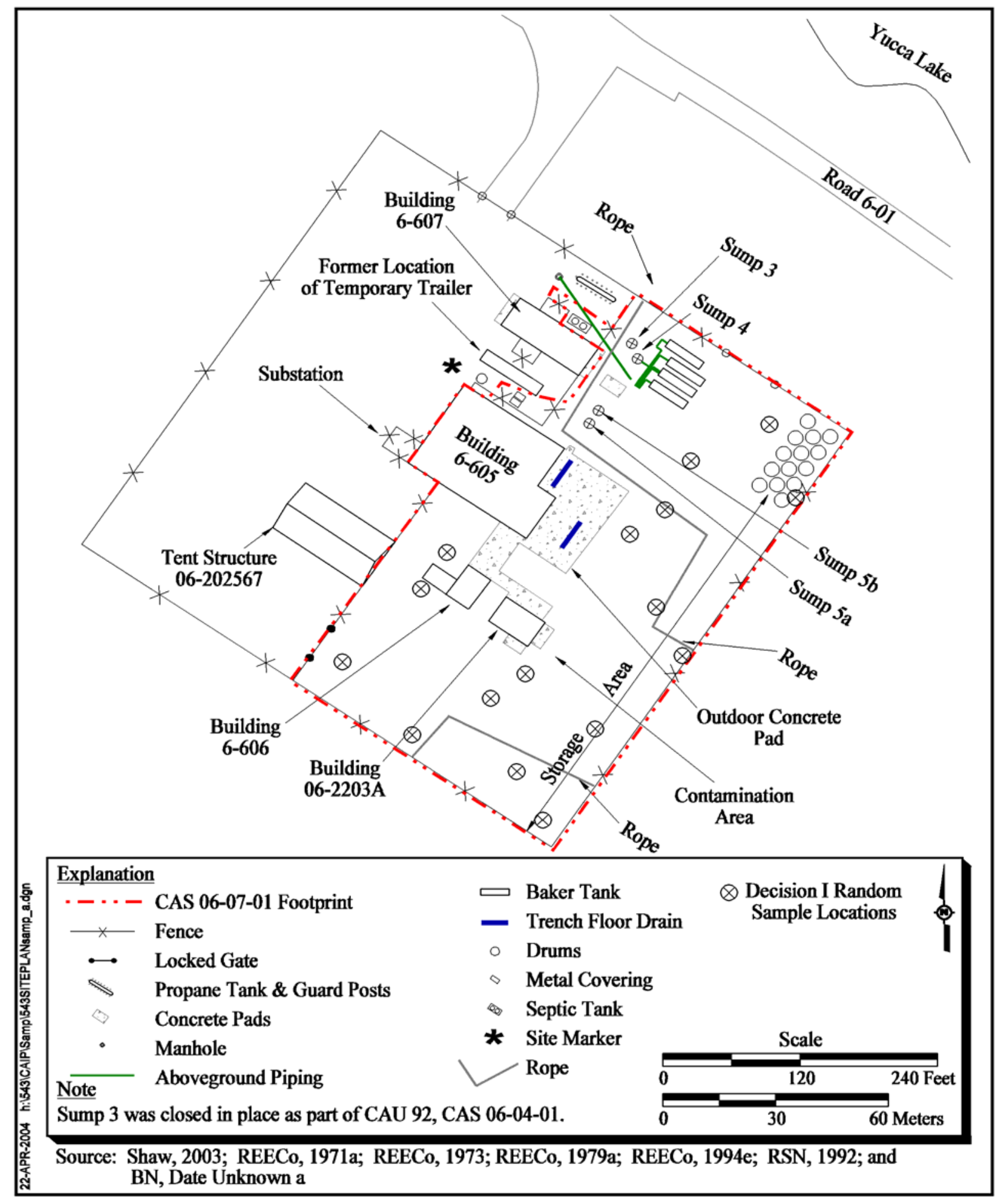

Figure 4-3

CAU 543, CAS 06-07-01, Decon Pad, Proposed Decision I Random Sample Locations 
If the interface cannot be identified, then samples will be collected directly beneath the distribution pipes.

The contents of the septic tank and distribution box will be sampled during Decision I for waste management purposes. Any remaining residual materials within piping or the cleanout will also be sampled provided enough volume is present. Figure 4-4 and Figure 4-5 show the proposed sampling locations for the septic tank and leachfield systems, respectively.

\section{CAS 15-08-01, Liquid Manure Tank}

Prior to collecting Decision I samples, a video-mole survey will be performed to identify if piping connects to the tank or is broken and if residual materials are present. Decision I subsurface soil samples will be collected from below the manure tank inlet and outlet and base of tank and at identified breaches within the piping. Surface soil samples will be collected at the liquid waste transfer point. Decision I surface soil samples will be collected at the outfall located to the south of the tank. Tank contents will be sampled if present. Figure 4-6 shows the proposed sample locations.

\section{CAS 15-23-03, Contaminated Sump}

Prior to Decision I sampling, a video-mole survey will be performed along the piping from the sump outfall to the distribution box to identify breaches and residual material. Decision I subsurface soil samples will be collected below the distribution box at the effluent end and breaches in the piping. The piping will be sampled to determine if it is transite (ACM). Decision I soil samples will be collected from surface locations within the sump floor to include at a minimum the location below the outfall pipe. Figure 4-7 shows the proposed sample locations for Decision I.

\section{CAS 15-01-03, Aboveground Storage Tank}

Decision I investigation at this CAS includes the soils at the AST, the AST, and piping that extends from the AST to the distribution box to Building 15-06 and the holding pen concrete drain box. Prior to sampling, a video mole survey will be performed to identify breaches or residual materials.

Decision I subsurface soil samples will be collected at identified breaks and the distribution box inlet and outlet. Surface soil samples will be collected from the base of the AST near the tank staining and at the transfer point of liquid waste. The piping at the transfer point will be sampled for potential 


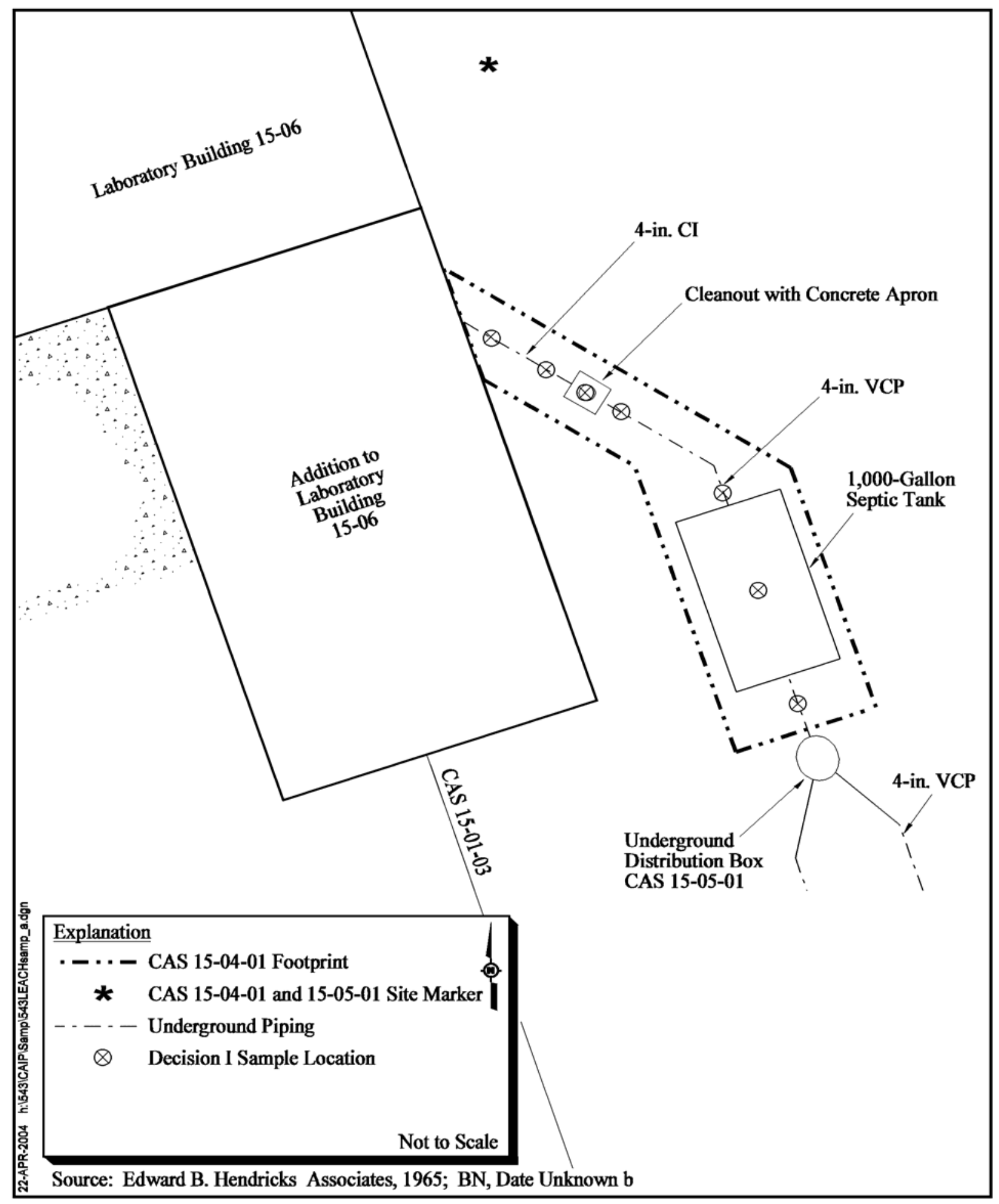

Figure 4-4

CAU 543, CAS 15-04-01, Septic Tank

Proposed Decision I Sample Locations 


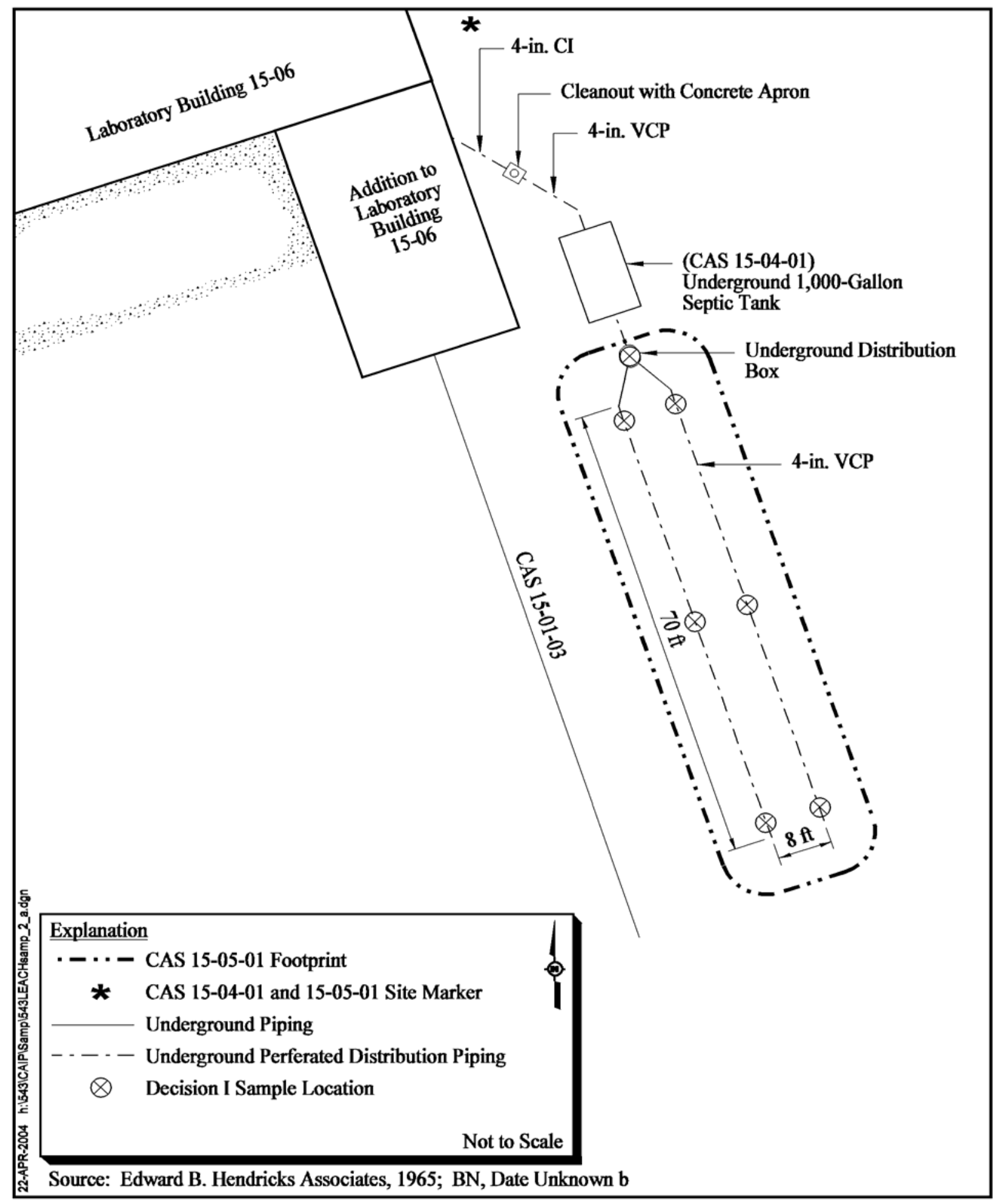

Figure 4-5

CAU 543, CAS 15-05-01, Leachfield

Proposed Decision I Sample Locations 


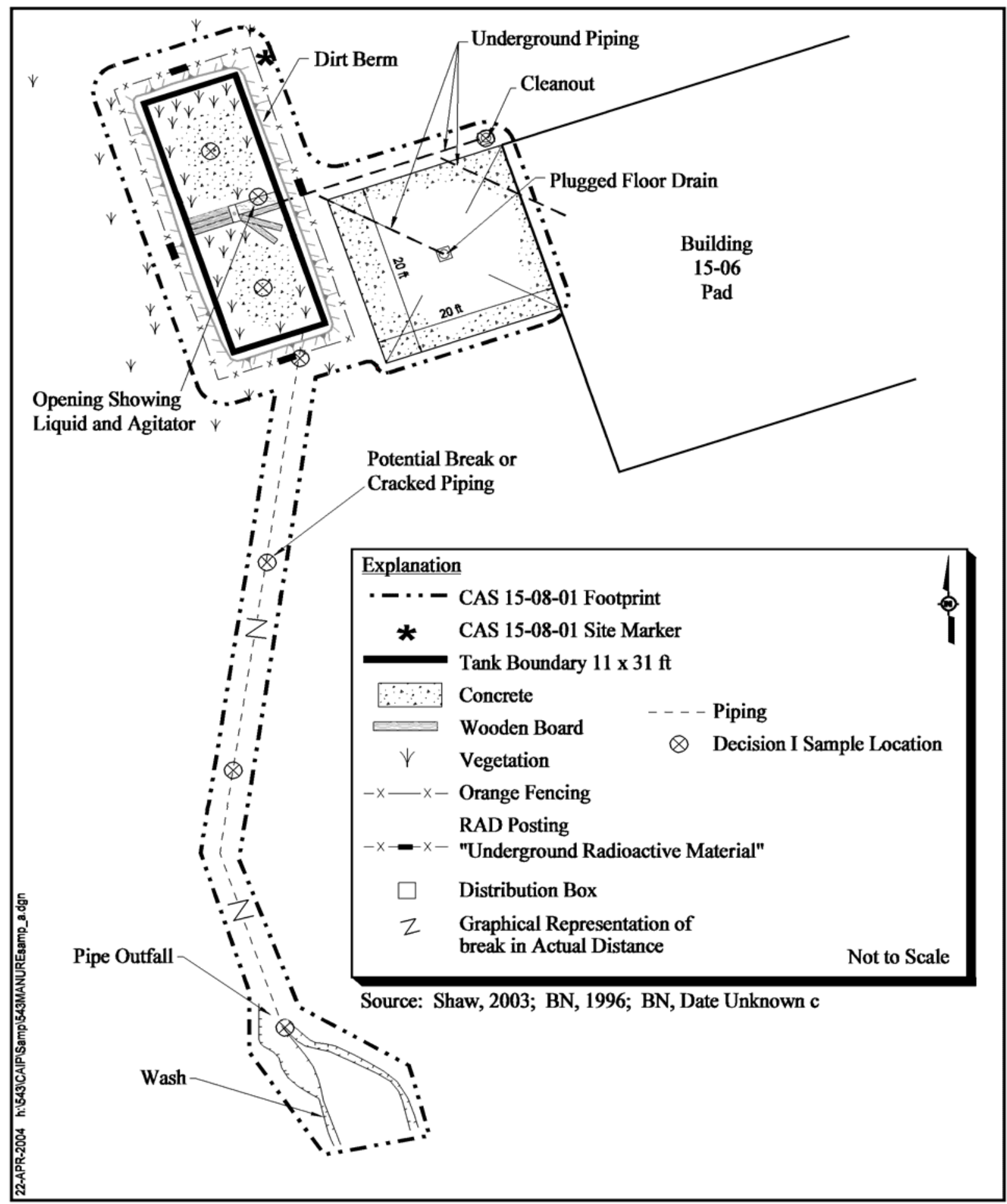

Figure 4-6

CAU 543, CAS 15-08-01, Liquid Manure Tank

Proposed Decision I Sample Locations 


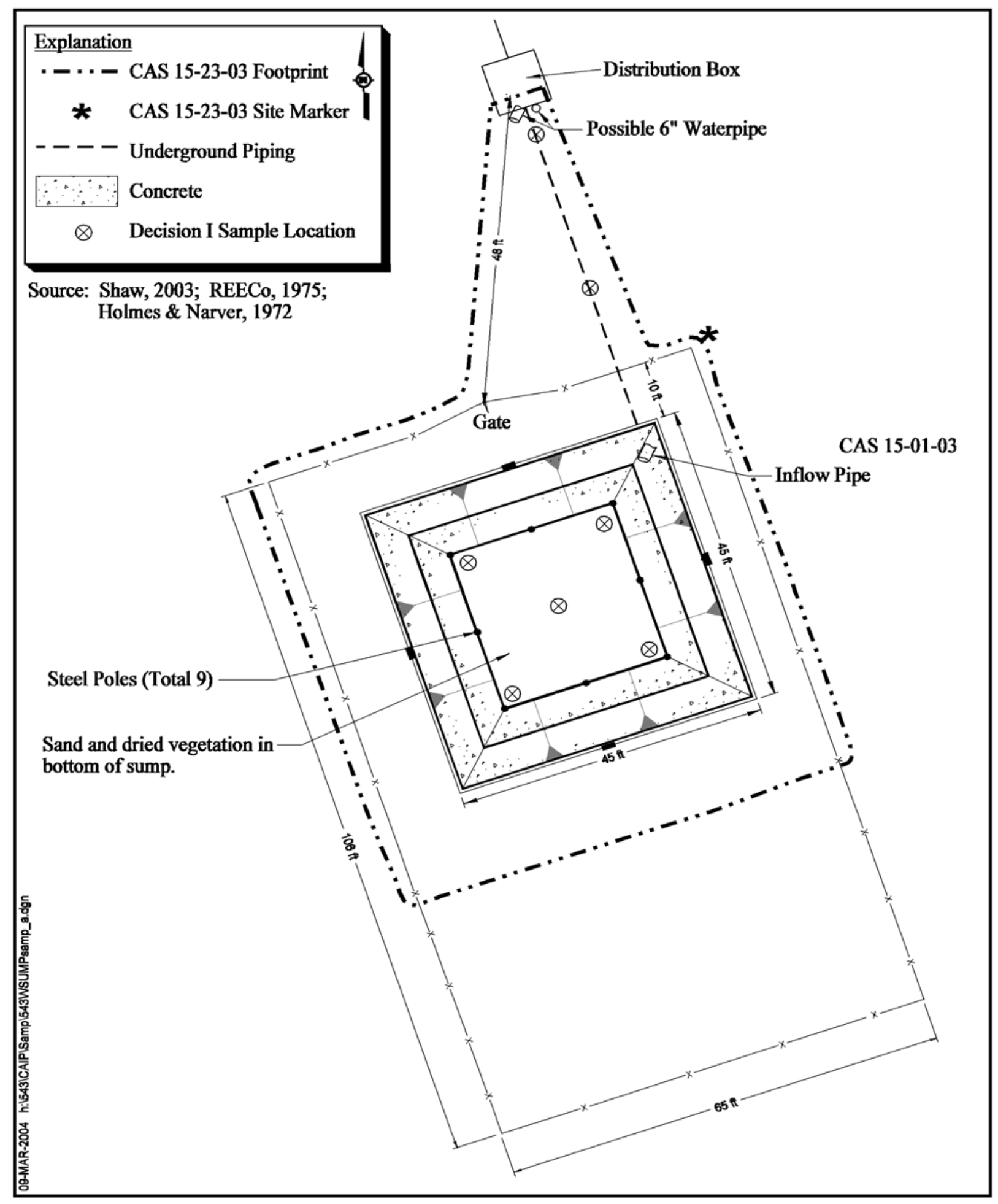

Figure 4-7

CAU 543, CAS 15-23-03, Contaminated Sump, Piping

Proposed Decision I Sample Locations 
ACM. Soil beneath the junctions at the concrete drain box and Building 15-06 will also be sampled during Decision I investigation. Figure 4-8 shows the proposed sample locations for Decision I.

\section{CAS 15-23-01, Decontamination Pad}

The Decision I investigation involves the surface soils located beneath and surrounding the PSP located on the ground. A radiological survey will be performed to determine if elevated radiological conditions exist. A shallow excavation may be performed to determine if a sump is present below the PSP. If biased sample locations are observed, Decision I soil samples will be collected. A statistical sampling approach is being implemented for the surface soils at this CAS. A total of nine surface samples will be collected within the area of the PSP to meet the 90 percent confidence level in the COPC concentration as determined by the methodology defined in Chapter 9 of EPA SW-846. Figure 4-9 shows the proposed random sampling locations.

Decision II sampling will be conducted to define the extent of contamination at the Area 15 CASs where Decision I samples indicate and/or confirm the presence of COCs, as described in Section 4.2.3.

\subsection{Geotechnical/Hydrological Analysis and Bioassessment Tests}

It may be necessary to measure the geotechnical/hydrological parameters of one or more of the CASs. Samples to be analyzed for these parameters will be collected within brass sleeves (or other containers, as appropriate) to maintain the natural physical characteristics of the soil. Table 4-1 lists general geotechnical and hydrological parameters of interest. The testing methods shown are minimum standards, and other equivalent or superior testing methods may be used. In some cases, bioassessment will also be performed on the sample material. Bioassessment is a series of tests designed to evaluate the physical, chemical, and microbiological characteristics of a site. Bioassessment tests include determinants of nutrient availability, $\mathrm{pH}$, microbial population density, and the ability of the microbial population to grow under enhanced conditions. This type of analysis may be required if it is determined that hydrocarbon contamination is present at a site where bioremediation is a potential corrective action. Bioassessment samples may be collected if biasing factors suggest that a fuel or solvent plume may be present. 


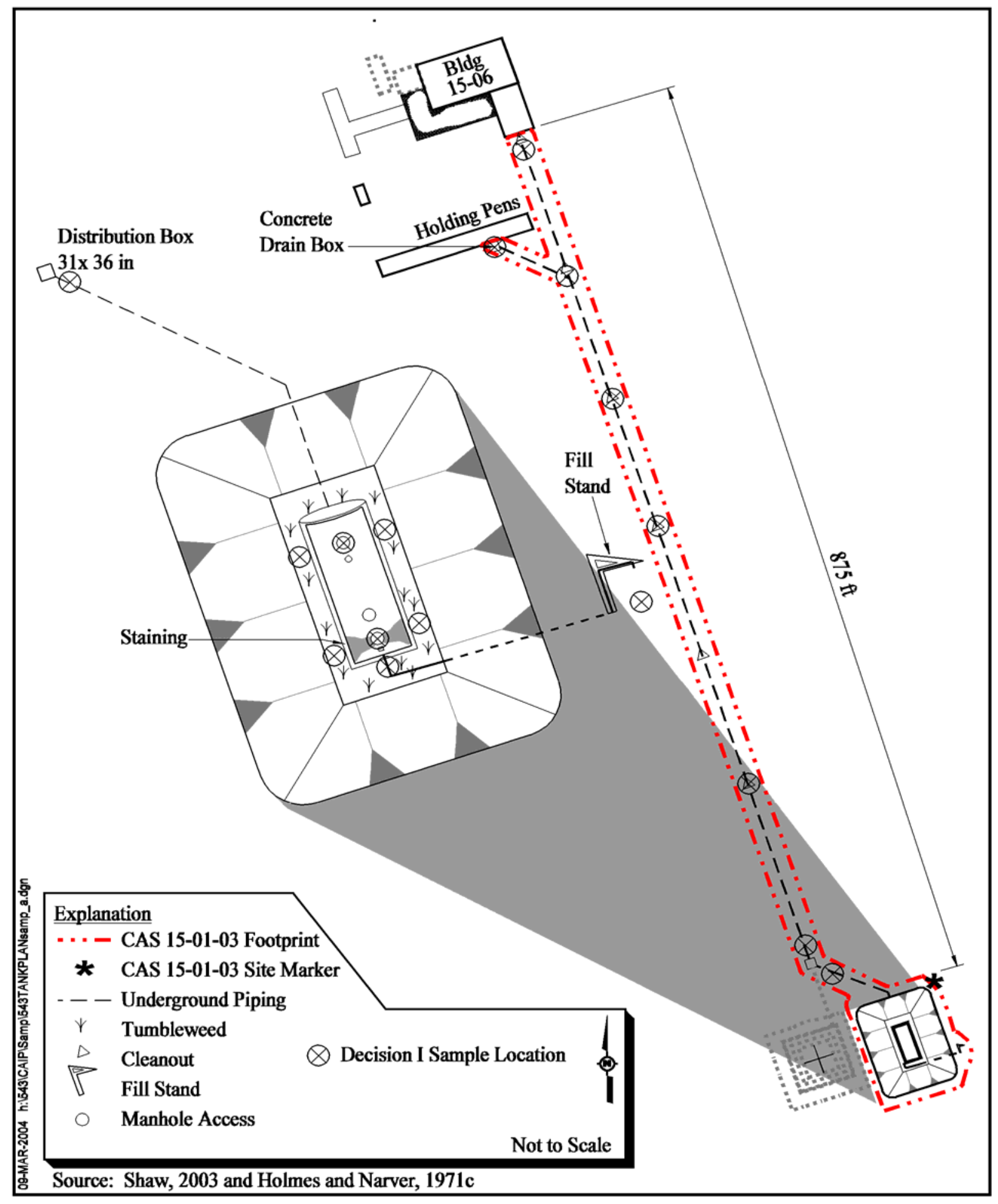

Figure 4-8

CAU 543, CAS 15-01-03, Aboveground Storage Tank

Proposed Decision I Sample Locations 


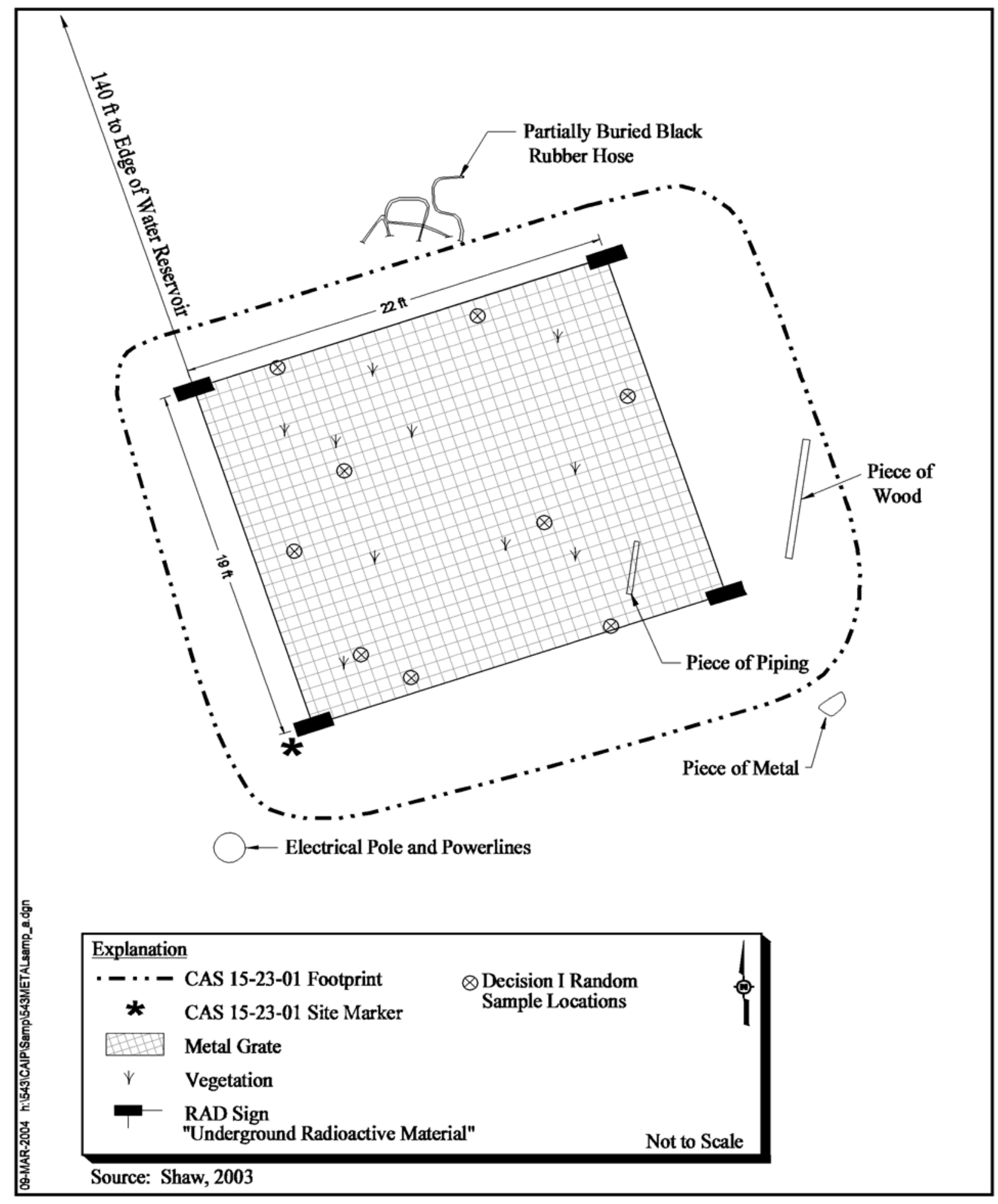

Figure 4-9

CAU 543, CAS 15-23-01, Underground Radioactive Material Area Proposed Decision I Random Sample Locations 
Table 4-1

General Geotechnical and Hydrological Analysis

\begin{tabular}{|c|c|}
\hline Geotechnical Parameter & Methods \\
\hline Initial moisture content & ASTM D 2216-92a \\
\hline Dry bulk density & ASTM D 2937-94 \\
\hline Calculated porosity & EM-1110-2-1906 or MOSA Chp. $18^{c}$ \\
\hline Saturated hydraulic conductivity & ASTM $2434-68(74)^{a}$ or MOSA Chp. $28^{c}$ \\
\hline Unsaturated hydraulic conductivity & van Genuchten ${ }^{d}$ \\
\hline Particle-size distribution & ASTM D 422-63(90) ${ }^{\mathrm{a}}$ \\
\hline Water-release (moisture retention) curve & $\begin{array}{c}\text { MOSA Chp. 26 } \\
\text { ASTM D 2325-68(94) }^{\mathrm{a}} \\
\text { MOSA Chp. 24 } \\
\text { Karanthanasis and Hajek }^{\mathrm{e}}\end{array}$ \\
\hline
\end{tabular}

${ }^{a}$ American Society for Testing and Materials (ASTM), 1996

bU.S. Army Corps of Engineers (USACE), 1970

${ }^{\mathrm{c}}$ Methods of Soil Analysis (MOSA) (Soil Science Society of America, 1986)

dvan Genuchten, 1980

${ }^{\mathrm{e}}$ Karanthanasis and Hajek, 1982

\subsection{Safety}

A current version of the Environmental Services Architect-Engineer Contractor's HASP will accompany the field documents, and a SSHASP, or equivalent will be prepared and approved prior to the field effort. As required by the DOE Integrated Safety Management System (ISMS)

(DOE/NV, 1997), these documents outline the requirements for protecting the health and safety of the workers and the public, and procedures for protecting the environment. The ISMS program requires that site personnel will reduce or eliminate the possibility of injury, illness, or accidents, and to protect the environment during all project activities. The following safety issues will be taken into consideration when evaluating the hazards and associated control procedures for field activities discussed in the SSHASP and field instructions:

- Potential hazards to site personnel and the public include, but are not limited to: radionuclides, chemicals (e.g., heavy metals, VOCs, SVOCs, PCBs, and petroleum hydrocarbons), adverse and rapidly changing weather, remote location, and motor vehicle and heavy equipment operations.

- Proper training of all site personnel to recognize and mitigate the anticipated hazards. 
- Work controls to reduce or eliminate the hazards including engineering controls, substitution of less hazardous materials, and use of appropriate personal protective equipment (PPE).

- Occupational exposure monitoring to prevent overexposures to hazards such as radionuclides, chemicals, and physical agents (e.g., heat, cold, and high wind).

- Emergency and contingency planning to include medical care and evacuation, decontamination, spill control measures, and appropriate notification of project management. The same principles apply to emergency communication.

- If potential ACM is identified (CFR, 2002c; NAC, 2002d), it will be inspected and/or samples collected by trained personnel.

- If septic tanks contain residual materials, samples will be collected and analyzed for total and fecal coliform bacteria on site. Any associated system component residual materials will also be analyzed if septic tank results show coliform bacteria. 


\subsection{Waste Management}

Management of IDW will be based on regulatory requirements, field observations, process knowledge, and the results of laboratory analysis of CAU 543 investigation samples.

Disposable sampling equipment, PPE, and rinsate are considered potentially contaminated waste only by virtue of contact with potentially contaminated media (e.g., soil) or potentially contaminated debris (e.g., construction materials). Therefore, sampling and analysis of IDW, separate from analyses of site investigation samples, may not be necessary. However, if associated investigation samples are found to contain contaminants above regulatory levels, direct samples of IDW may be taken to support waste characterization.

Sanitary, hydrocarbon, hazardous, radioactive and/or mixed waste, if generated, will be managed and disposed of in accordance with DOE Orders, U.S. Department of Transportation (DOT) regulations, state and federal waste regulations, and agreements and permits between DOE and NDEP.

\subsection{Waste Minimization}

Investigation activities are planned to minimize IDW generation. This will be accomplished by incorporating the use of process knowledge, visual examination, swipe results, and/or radiological survey. When possible, disturbed media (such as soil removed during trenching) or debris will be returned to its original location. Contained media (e.g., soil managed as waste) as well as other IDW will be segregated to the greatest extent possible to minimize generation of hazardous, radioactive, or mixed waste. Hazardous material used at the sites will be controlled in order to limit unnecessary generation of hazardous or mixed waste. Administrative controls, including decontamination procedures and waste characterization strategies, will minimize waste generated during investigations.

\subsection{Potential Waste Streams}

Waste generated during the investigation activities may include the following:

- PPE and disposable sampling equipment (e.g., plastic sheeting, paper, glass and plastic sample jars, sampling scoops, aluminum foil, bowls) 
- Decontamination rinsate

- $\quad$ Environmental media (e.g., soil, sludge, liquids, sediment)

- Field-screening waste (e.g., soil, spent solvent, rinsate, disposal sampling equipment, and contaminated PPE)

- Surface debris in the investigation area

- $\quad \mathrm{ACM}$ (i.e., transite septic system pipe)

Office trash and lunch waste will be sent to the sanitary landfill by placing waste in a trash dumpster.

\subsection{Investigation-Derived Waste Management}

The on-site management and ultimate disposition of IDW may be guided by several factors, including, but not limited to: the analytical results of samples either directly or indirectly associated with the waste, historical site knowledge, knowledge of the waste generation process, field observations, field-monitoring/screening results, and/or radiological survey/swipe results. Each waste stream generated will be reviewed and segregated based on available knowledge and data at the point of generation by the following waste types:

- Sanitary waste

- Hazardous waste

- Polychlorinated biphenyls

- Low-level waste

- Mixed waste

Table 4-2 of the NV/YMP RadCon Manual (DOE/NV, 2000b) shall be used to determine if such materials may be declared nonradioactive. On-site IDW management requirements by waste type are detailed in the following sections. Applicable waste management regulations and requirements are listed in Table 5-1.

\subsubsection{Sanitary Waste}

Investigation-derived waste will be visually inspected and radiologically surveyed, as necessary, at the port of generation. It will be segregated and dispositioned if it meets the waste acceptance criteria for sanitary waste disposal facilities. Sanitary IDW generated at each CAS will be collected in plastic 
Table 5-1

Waste Management Regulations and Requirements

\begin{tabular}{|c|c|c|}
\hline Waste Type & Federal Regulation & Additional Requirements \\
\hline Solid (nonhazardous) & NA & $\begin{array}{c}\text { NRS }^{a} 444.440-444.620 \\
\text { NAC }^{b} 444.570-444.7499 \\
\text { NTS Landfill Permit SW13.097.04 } \\
\text { NTS Landfill Permit SW13.097.03 }\end{array}$ \\
\hline Liquid/Rinsate (nonhazardous) & NA & $\begin{array}{l}\text { Water Pollution Control General Permit } \\
\text { GNEV93001, Rev. 3iii }\end{array}$ \\
\hline Hazardous & $\begin{array}{c}\text { RCRA }^{f} \\
40 \text { CFR 260-282 }\end{array}$ & $\begin{array}{c}\text { NRS }^{\mathrm{a}} 459.400-459.600 \\
\mathrm{NAC}^{\mathrm{b}} 444.850-444.8746 \\
\mathrm{POC}^{\mathrm{g}}\end{array}$ \\
\hline Low-Level Radioactive & NA & DOE Orders and NTSWAC ${ }^{\text {h }}$ \\
\hline Mixed & $\begin{array}{c}\text { RCRA }^{f} \\
40 \text { CFR 260-282 }\end{array}$ & $\begin{array}{l}\text { NTSWAC }^{\mathrm{h}} \\
\text { POC }^{\mathrm{g}}\end{array}$ \\
\hline Hydrocarbon & NA & NTS Landfill Permit SW13.097.02i \\
\hline Polychlorinated Biphenyls & $\begin{array}{c}\text { TSCA }^{\mathrm{j}} \\
40 \text { CFR } 761\end{array}$ & $\begin{array}{l}\text { NRS }^{a} 459.400-459.600 \\
\text { NAC }^{b} 444.940-444.9555\end{array}$ \\
\hline Asbestos & $\begin{array}{c}\text { TSCA }^{\mathrm{j}} \\
40 \mathrm{CFR} 763\end{array}$ & $\begin{array}{l}\text { NRS }^{a} 618.750-618.840 \\
\text { NAC }^{b} 444.965-444.976\end{array}$ \\
\hline
\end{tabular}

${ }^{a}$ Nevada Revised Statutes (NRS, 2003a, b, and c)

${ }^{\mathrm{b}}$ Nevada Administrative Code (NAC, 2002a, b, c, and d)

${ }^{c}$ Area 23 Class II Solid Waste Disposal Site (NDEP, 1997a)

${ }^{\mathrm{d} A r e a} 9$ Class III Solid Waste Disposal Site (NDEP, 1997c)

${ }^{\mathrm{e}}$ Nevada Test Site Sewage Lagoons (NDEP, 1999)

${ }^{\mathrm{f}}$ Resource Conservation and Recovery Act (CFR, 2003a)

${ }^{9}$ Performance Objective for the Certification of Nonradioactive Hazardous Waste (BN, 1995)

${ }^{\mathrm{h}}$ Nevada Test Site Waste Acceptance Criteria, Revision 5 (NNSA/NSO, 2003)

'Area 6 Class III Solid Waste Disposal Site for Hydrocarbon (NDEP, 1997b)

${ }^{\mathrm{j} T}$ Toxic Substance Control Act (CFR, 2003b and c)

NA $=$ Not applicable

NAC $=$ Nevada Administrative Code

NRS $=$ Nevada Revised Statutes

NTS $=$ Nevada Test Site

RCRA = Resource Conservation and Recovery Act

NTSWAC = Nevada Test Site Waste Acceptance Criteria

TSCA = Toxic Substance Control Act

$\mathrm{POC}=$ Performance Objective for the Certification of Nonradioactive Hazardous Waste 
bags, sealed, labeled with the CAS number from each site in which it was generated, and dated. The waste will then be placed in a designated rolloff box located in Mercury, or other approved rolloff box location. The number of bags of sanitary IDW placed in the rolloff box will be counted as they are placed in the rolloff box, and noted in the log, as well as documented in the field activity daily log (FADL). These logs will provide necessary tracking information for ultimate disposal in the 10c Industrial Waste Landfill, or other approved landfill.

\subsubsection{Special Sanitary}

Hydrocarbon waste is defined as waste containing more than $100 \mathrm{mg} / \mathrm{kg}$ of TPH contamination (NAC, 2003). Hydrocarbon waste will be managed on site in a drum or other appropriate container until fully characterized. Hydrocarbon waste may be disposed of at a designated hydrocarbon landfill (NDEP, 1997b), an appropriate hydrocarbon waste management facility (e.g., recycling facility), or other method in accordance with State of Nevada regulations.

Asbestos-containing materials that may be encountered or generated during this investigation will be managed and disposed of in accordance with appropriate federal (CFR, 2003c) and State of Nevada (NAC, 2002d) regulations.

Materials that are thought to potentially contain the hantavirus will be managed and disposed in accordance with appropriate health and safety procedures.

\subsubsection{Hazardous Waste}

The CAU will have waste storage areas established according to the needs of the project. Satellite accumulation areas and hazardous waste accumulation areas will be managed consistent with the requirements of federal and state regulations (CFR, 2003a and NAC, 2002b). They will be properly controlled for access and equipped with spill kits and appropriate spill containment. Suspected hazardous wastes will be placed in DOT-compliant containers. All containerized waste will be handled, inspected, and managed in accordance with Title 40 CFR 265, Subpart I (CFR, 2003a). These provisions include managing the waste in containers compatible with the waste type, and segregating incompatible waste types so that in the event of a spill, leak, or release, incompatible wastes shall not contact one another. 
Hazardous waste accumulation areas will be covered under a site-specific emergency response and contingency action plan until such time that the waste is determined to be nonhazardous or all containers of hazardous waste have been removed from the storage area. Hazardous wastes will be characterized in accordance with the requirements of Title 40 CFR 261 (CFR, 2003a). No RCRA "listed" wastes have been identified at CAU 543. Direct sampling of waste or request for TCLP analysis may be requested by the Waste Management Lead or Site Supervisor if necessary. Any waste determined to be hazardous will be managed as characteristic waste and transported in accordance with RCRA and DOT to a permitted treatment, storage, and disposal facility.

\subsubsection{Management of Personal Protective Equipment}

Personal protective equipment and disposable sampling equipment will be visually inspected for stains, discoloration, and gross contamination as the waste is generated. Any IDW that meets this description will be segregated and managed as potentially "characteristic" hazardous waste. This segregated population of waste will either be (1) assigned the characterization of the soil/sludge that was sampled, (2) sampled directly, or (3) undergo further evaluation using the soil/sludge sample results to determine how much soil/sludge would need to be present in the waste to exceed regulatory levels. Waste that is determined to be hazardous will be entered into an approved waste management system, where it will be managed and dispositioned according to RCRA requirements or subject to agreements between NNSA/NSO and the State of Nevada. The PPE and equipment that is not visibly stained, discolored, or grossly contaminated and that is within radiological free-release criteria will be managed as nonhazardous sanitary waste.

\subsubsection{Management of Decontamination Rinsate}

Rinsate at this CAU will not be considered hazardous waste unless there is evidence that the rinsate would display a RCRA characteristic. Evidence may include such things as the presence of a visible sheen, $\mathrm{pH}$, or association with equipment/materials used to respond to a release/spill of a hazardous waste/substance. Decontamination rinsate that is potentially hazardous (using associated sample results and/or process knowledge) will be managed as "characteristic" hazardous waste (CFR, 2003a). The regulatory status of the potentially hazardous rinsate will be determined through the application of associated sample results or through direct sampling. If determined to be hazardous, the rinsate will be entered into an approved waste management system, where it will be 
managed and dispositioned according to RCRA requirements or subject to agreements between NNSA/NSO and the State of Nevada. If the associated samples do not indicate the presence of hazardous constituents, then the rinsate will be considered to be nonhazardous.

The disposal of nonhazardous rinsate will be consistent with guidance established in current NNSA/NSO Fluid Management Plans for the NTS as follows:

- Rinsate that is determined to be nonhazardous and contaminated to less than 5x Safe Drinking Water Standards (SDWS) is not restricted as to disposal. Nonhazardous rinsate which is contaminated at 5x to 10x SDWS will be disposed of in an established infiltration basin or solidified and disposed of as sanitary waste or low-level waste in accordance with the respective sections of this document.

- Nonhazardous rinsate which is contaminated at greater than 10x SDWS will be disposed of in a lined basin or solidified and disposed of as sanitary waste or low-level waste in accordance with the respective sections of this document.

\subsubsection{Management of Soil}

This waste stream consists of soil produced during soil sampling, excavation, and/or drilling. This waste stream is considered to have the same COPCs as the material remaining in the ground. The preferred method for managing this waste stream is to place the material back into the borehole/excavation in the same approximate location from which it originated. If this cannot be accomplished, the material will either be managed on site by berming and covering next to the excavation, or by placement in a container(s). The disposal of soil may be deferred until implementation of corrective action at the site.

\subsubsection{Management of Debris}

This waste stream can vary depending on site conditions. Debris that requires removal for the investigation activities (soil sampling, excavation, and/or drilling) must be characterized for proper management and disposition. Historical site knowledge, knowledge of the waste generation process, field observations, field-monitoring/screening results, radiological survey/swipe results and/or the analytical results of samples either directly or indirectly associated with the waste will be used to characterized the debris. Debris will be visually inspected for stains, discoloration, and gross contamination. Debris may be deemed reusable, recyclable, sanitary waste, hazardous waste, PCB 
waste, mixed waste, or low-level waste. Waste that is not sanitary will be entered into an approved waste management system, where it will be managed and dispositioned according to federal, state requirements, and agreements between NNSA/NSO and the State of Nevada. The debris will either be managed on site by berming and covering next to the excavation, or by placement in a container(s). The disposal of debris may be deferred until implementation of corrective action at the site.

\subsubsection{Field-Screening Waste}

The use of field test kits and/or instruments may result in the generation of small quantities of hazardous wastes. If hazardous waste is produced by field screening, it will be segregated from other IDW and managed in accordance with the hazardous waste regulations (CFR, 2003a). On radiological sites, this may increase the potential to generate mixed waste; however, the generation of a mixed waste will be minimized as much as practicable. In the event a mixed waste is generated, the waste will be managed in accordance with Section 5.3.5.

\subsubsection{Polychlorinated Biphenyls}

The management of PCBs is governed by the Toxic Substances Control Act (TSCA) (USC, 1976) and its implementing regulations at 40 CFR 761 (CFR, 2003b). Polychlorinated biphenyls contamination may be found as a sole contaminant or in combination with any of the types of waste discussed in this document. For example, PCBs may be a cocontaminant in soil that contains a RCRA "characteristic" waste (PCB/hazardous waste), or in soil that contains radioactive wastes (PCB/ radioactive waste), or even in mixed waste (PCB/radioactive/hazardous waste). The IDW will initially be evaluated using analytical results for media samples from the investigation. If any type of PCB waste is generated, it will be managed according to 40 CFR 761 (CFR, 2003b) as well as State of Nevada requirements, (NAC, 2002c) guidance, and agreements with NNSA/NSO.

\subsubsection{Low-Level Waste}

Radiological swipe surveys and/or direct-scan surveys may be conducted on reusable sampling equipment and the PPE and disposable sampling equipment waste streams exiting a radiologically controlled area. This allows for the immediate segregation of radioactive waste from waste that may be unrestricted regarding radiological release. Removable contamination limits, as defined in 
Table 4-2 of the current version of the NV/YMP RadCon Manual (DOE/NV, 2000b), will be used to determine if such waste may be declared unrestricted regarding radiological release versus being declared radioactive waste. Direct sampling of the waste may be conducted to aid in determining if a particular waste unit (e.g., drum of soil) contains low-level radioactive waste, as necessary. Waste that is determined to be below the values of Table 4-2, by either direct radiological survey/swipe results or through process knowledge, will not be managed as potential radioactive waste but will be managed in accordance with the appropriate section of this document. Wastes in excess of Table 4-2 values will be managed as potential radioactive waste and be managed in accordance with this section and any other applicable sections of this document.

Low-level radioactive waste, if generated, will be managed in accordance with the contractor-specific waste certification program plan, DOE Orders, and the requirements of the current version of the Nevada Test Site Waste Acceptance Criteria (NTSWAC) (NNSA/NSO, 2003). Potential radioactive waste drums containing soil, PPE, disposable sampling equipment, and/or rinsate may be staged at a designated Radioactive Materials Area (RMA) or radiologically controlled area when full or at the end of an investigation phase. The waste drums will remain at the RMA pending certification and disposal under NTSWAC requirements (NNSA/NSO, 2003).

\subsubsection{Mixed Waste}

Mixed waste, if generated, shall be managed and dispositioned according to the requirements of RCRA (CFR, 2003a) or subject to agreements between NNSA/NSO and the State of Nevada, as well as DOE requirements for radioactive waste. The waste will be marked with the words "Hazardous Waste Pending Analysis and Radioactive Waste Pending Analysis.” Waste characterized as mixed will not be stored for a period of time that exceeds the requirements of RCRA unless subject to agreements between NNSA/NSO and the State of Nevada. The mixed waste shall be transported via an approved hazardous waste/radioactive waste transporter to the NTS transuranic waste storage pad for storage pending treatment or disposal. Mixed waste with hazardous waste constituents below Land Disposal Restrictions may be disposed of at the NTS Area 5 Radioactive Waste Management 
Site if the waste meets the requirements of the NTSWAC (NNSA/NSO, 2003). Mixed waste not meeting Land Disposal Restrictions will require development of a treatment and disposal plan under the requirements of the Mutual Consent Agreement between DOE and the State of Nevada (NDEP, 1995). 


\subsection{Quality Assurance/Quality Control}

The overall objective of the characterization activities described in this CAIP is to collect accurate and defensible data to support the selection and implementation of a closure alternative for each CAS in CAU 543. Section 6.1 and Section 6.2 discuss the collection of required QC samples in the field and QA requirements for laboratory/analytical data to achieve closure. Section 6.3 provides QA/QC requirements for radiological survey data. Unless otherwise stated in this CAIP or required by the results of the DQO process (Appendix A.1), this investigation will adhere to the Industrial Sites QAPP (NNSA/NV, 2002).

\subsection{Quality Control Field Sampling Activities}

Field QC samples will be collected in accordance with approved procedures. Field QC samples are collected and analyzed to aid in determining the validity of sample results. The number of required QC samples depends on the types and number of investigation (i.e., environmental and waste characterization) samples collected. The minimum frequency of collecting and analyzing QC samples established for this investigation include:

- Trip blanks (one per sample cooler containing VOC environmental samples)

- Equipment blanks (one per sampling event for each type of decontamination procedure)

- Source blanks (one per lot of source material that contacts sample media)

- $\quad$ Field duplicates (1 per 20 environmental samples)

- Field blanks (minimum of 1 per 20 environmental samples)

- Matrix spike (MS)/matrix spike duplicate (MSD) (1 per 20 environmental samples, not required for all radionuclide measurements)

Additional QC samples may be submitted based on site conditions and technical judgement of the Site Supervisor. Field QC samples shall be analyzed using the same analytical procedures implemented for associated environmental samples. Additional details regarding field QC samples are available in the Industrial Sites QAPP (NNSA/NV, 2002). 


\subsection{Laboratory and Analytical Quality Assurance}

Criteria for the investigation, as stated in the DQOs (Appendix A.1) and except where noted, require laboratory analytical data be used for making critical decisions. Rigorous QA/QC will be implemented for all laboratory samples including documentation, data verification and validation of analytical results, and an assessment of data quality indicators (DQIs) as they relate to laboratory analysis.

\subsubsection{Data Validation}

Data verification and validation will be performed in accordance with the Industrial Sites QAPP (NNSA/NV, 2002), except where otherwise stipulated in this CAIP. All nonradiological laboratory data from samples collected and analyzed will be evaluated for data quality according to EPA's Contract Laboratory Program National Functional Guidelines (EPA, 1994a and 1999). Radiological laboratory data from samples that are collected and analyzed will be evaluated for data quality according to company-specific procedures. The data will be reviewed to ensure that all critical samples were appropriately collected and analyzed, and that the results met data validation criteria. Validated data, including estimated data (i.e., J-qualified), will be assessed to determine if they meet the DQO requirements of the investigation and the performance criteria for the DQIs. The results of this assessment will be documented in the CAU 543 CADD. If the DQOs are not met, corrective actions will be evaluated, selected and implemented (e.g., refine CSM or resample) to fill data gaps.

\subsubsection{Data Quality Indicators}

Data quality indicators are qualitative and quantitative descriptors used in interpreting the degree of acceptability or utility of data. The principal DQIs are precision, accuracy, representativeness, comparability, and completeness. A sixth DQI, sensitivity, has also been included for the CAU 543 investigation. Data quality indicators are used to evaluate the entire measurement system and laboratory measurement processes (i.e., analytical method performance) as well as to evaluate individual analytical results (i.e., parameter performance).

Precision and accuracy are quantitative measures used to assess overall analytical method and field sampling performance as well as to assess the need to "flag" (qualify) individual parameter results when corresponding QC sample results are not within established control limits. Therefore, 
performance metrics have been established for both analytical methods and individual analytical results. Data qualified as estimated for reasons of precision or accuracy may be considered to meet the parameter performance criteria based on assessment of the data.

Representativeness and comparability are qualitative measures, and completeness is a combination of both quantitative and qualitative measures. Representativeness, comparability, and completeness are used to assess the measurement system performance. The DQI parameters are individually discussed in Section 6.2.3 through Section 6.2.8.

Table 6-1 provides the established analytical method/measurement system performance criteria for each of the DQIs and the potential impacts to the decision if the criteria are not met. The Industrial Sites QAPP (NNSA/NV, 2002) documents the actions required to correct conditions that adversely affect data quality both in the field and the laboratory. All DQI performance criteria deficiencies will be evaluated for data usability and impacts to the DQO decisions. These evaluations will be discussed and documented in the data assessment section of the CADD. The following subsections discuss each of the DQIs that will be used to assess the quality of laboratory data.

\subsubsection{Precision}

Precision is used to assess the variability of a population of measurements with the variability of the analysis process. The method used to calculate relative percent difference (RPD) is presented in the Industrial Sites QAPP (NNSA/NV, 2002).

Determinations of precision will be made for field duplicate samples and laboratory duplicate samples. Field duplicate samples will be collected simultaneously with samples from the same source under similar conditions in separate containers. The duplicate sample will be treated independently of the original sample in order to assess field impacts and laboratory performance on precision through a comparison of results. Laboratory precision is evaluated as part of the required laboratory internal QC program to assess performance of analytical procedures. The laboratory sample duplicates are an aliquot, or subset, of a field sample generated in the laboratory. They are not a separate sample but a split, or portion, of an existing sample. Typically, laboratory duplicate QC samples include MSD and laboratory control sample (LCS) duplicate samples for organic, inorganic, and radiological analyses. 
Table 6-1

Laboratory and Analytical Performance Criteria for CAU 543 Data Quality Indicators

\begin{tabular}{|c|c|c|}
\hline $\begin{array}{l}\text { Data Quality } \\
\text { Indicator }\end{array}$ & Performance Criteria & $\begin{array}{l}\text { Potential Impact on Decision if } \\
\text { Performance Criteria Not Met }\end{array}$ \\
\hline Precision & $\begin{array}{l}\text { Variations between duplicates (laboratory and } \\
\text { field) and original sample should not exceed } \\
\text { analytical method-specific criteria discussed in } \\
\text { Section } 6.2 .3 \text {. }\end{array}$ & $\begin{array}{l}\text { Data that do not meet the performance } \\
\text { criteria will be evaluated for purposes of } \\
\text { completeness. Decisions may not be valid } \\
\text { if analytical method performance criteria } \\
\text { for precision are not met. }\end{array}$ \\
\hline Accuracy & $\begin{array}{l}\text { Laboratory control sample, matrix spike, and } \\
\text { surrogate results should be within specified } \\
\text { acceptance windows. }\end{array}$ & $\begin{array}{l}\text { Data that do not meet the performance } \\
\text { criteria will be evaluated for purposes of } \\
\text { completeness. Decisions may not be valid } \\
\text { if analytical method performance criteria } \\
\text { for accuracy are not met. }\end{array}$ \\
\hline Sensitivity & $\begin{array}{l}\text { Laboratory detection limits must be less than } \\
\text { or equal to respective PALs. }\end{array}$ & $\begin{array}{l}\text { Cannot determine if COCs are present or } \\
\text { migrating at levels of concern; therefore, } \\
\text { the affected data will be assessed for } \\
\text { usability and potential impacts on meeting } \\
\text { site characterization objectives. }\end{array}$ \\
\hline Comparability & $\begin{array}{l}\text { Equivalent samples analyzed using same } \\
\text { analytical methods, the same units of } \\
\text { measurement and detection limits must be } \\
\text { used for like analyses. }\end{array}$ & $\begin{array}{l}\text { Inability to combine data with data } \\
\text { obtained from other sources and/or } \\
\text { inability to compare data to regulatory } \\
\text { action levels. }\end{array}$ \\
\hline Representativeness & $\begin{array}{l}\text { Correct analytical method performed for } \\
\text { appropriate COPC; valid data reflects } \\
\text { appropriate target population. }\end{array}$ & $\begin{array}{l}\text { Cannot identify COC or estimate } \\
\text { concentration of COC; therefore, cannot } \\
\text { make decision(s) on target population. }\end{array}$ \\
\hline $\begin{array}{c}\text { Nature } \\
\text { Completeness }\end{array}$ & $\begin{array}{l}80 \% \text { of the CAS-specific noncritical analytes } \\
\text { identified in the CAIP have valid results. } 90 \% \\
\text { of critical analytes are valid. }\end{array}$ & $\begin{array}{l}\text { Cannot make decision on whether COCs } \\
\text { are present. }\end{array}$ \\
\hline $\begin{array}{c}\text { Extent } \\
\text { Completeness }\end{array}$ & $\begin{array}{l}90 \% \text { of critical analytes used to define extent of } \\
\text { COCs are valid. }\end{array}$ & $\begin{array}{l}\text { Extent of contamination cannot be } \\
\text { determined. }\end{array}$ \\
\hline $\begin{array}{l}\text { Clean Closure } \\
\text { Completeness }\end{array}$ & $90 \%$ of critical analytes are valid. & Cannot determine if COCs remain in soil. \\
\hline
\end{tabular}




\subsubsection{Precision for Chemical Analysis}

The RPD criteria to be used for assessment of precision are the parameter-specific criteria listed in Table 3-4. No review criteria for field duplicate RPD comparability have been established; therefore, the laboratory sample duplicate criteria will be applied to the review of field duplicates.

The parameter performance criteria for precision will be compared to RPD results of duplicate samples. This will be accomplished as part of the data validation process. Precision values for organic and inorganic analyses that are within the established control criteria indicate that analytical results for associated samples are valid. The RPD values that are outside the criteria for organic analysis do not necessarily result in the qualification of analytical data. It is only one factor in making an overall judgement about the quality of the reported analytical results. Inorganic laboratory sample duplicate RPD values outside the established control criteria result in the qualification of associated analytical results as estimated; however, qualified data does not necessarily indicate that the data are not useful for the purpose intended. This qualification is an indication that data precision should be considered for the overall assessment of the data quality and potential impact on data applicability in meeting site characterization objectives.

The criteria to evaluate analytical method performance for precision will be assessed based on the analytical method-specific (e.g., VOCs) precision measurements. Each analytical method-specific precision measurement will be assessed for potential impacts on meeting site characterization objectives, and results of the assessment will be documented in the CADD.

\subsubsection{Precision for Radiological Analysis}

The parameter performance criteria for precision will be compared to the RPD or normalized difference (ND) results of duplicate samples. The criteria for assessment of the radiochemical precision are parameter-specific criteria (see Table 3-3). This assessment will be accomplished as part of the data validation process. Precision values that are within the established control criteria indicate that analytical results for associated samples are valid. Out of control RPD or ND values do not necessarily indicate that the data are not useful for the purpose intended; however, it is an indication that data precision should be considered for the overall assessment of the data quality and the potential impact on data applicability in meeting site characterization objectives. 
If the RPD or ND criteria are exceeded, samples will be qualified. Field duplicates will be evaluated, but field samples will not be qualified based on their results. The MSD results, obtained for some analyses, outside of the control limits may not result in qualification of the data. An assessment of the entire analytical process, including the sample matrix, will be conducted to determine if qualification is warranted.

Each analytical method-specific precision measurement will be assessed for potential impacts on meeting site characterization objectives, and results of the assessment will be documented in the CADD.

\subsubsection{Accuracy}

Accuracy is a measure of the closeness of an individual measurement or the average of a number of measurements to the true value. It is used to assess the performance of laboratory measurement processes as well as to evaluate individual groups of analyses (i.e., sample delivery groups).

Accuracy is determined by analyzing a reference material of known parameter concentration or by reanalyzing a sample to which a material of known concentration or amount of parameter has been added (spiked).

\subsubsection{Accuracy for Chemical Analyses}

The criteria to be used for assessment of accuracy are the parameter-specific criteria listed in Table 3-4. Accuracy for chemical analyses will be evaluated based on results from three types of spiked samples: MS, LCS, and surrogates.

For organic analyses, laboratory control limits are used for evaluation of percent recovery. The acceptable control limits for organic analyses are established in the EPA Contract Laboratory Program National Functional Guidelines for Organic Data Review (EPA, 1999).

The percent recovery parameter performance criteria for accuracy will be compared to percent recovery results of spiked samples. This will be accomplished as part of the data validation process. The percent recovery values that are outside the criteria do not necessarily result in the qualification of analytical data. It is only one factor in making an overall judgment about the quality of the 
reported analytical results. Factors beyond the laboratory's control, such as sample matrix effects, can cause the measured values to be outside of the established criteria. Therefore, the entire sampling and analytical process must be evaluated when determining the quality of the analytical data provided.

The criteria to evaluate analytical method performance for accuracy will be based on the analytical method-specific (e.g., VOCs) accuracy measurements. Each analytical method-specific accuracy measurement will be assessed for potential impacts on meeting site characterization objectives, and results of the assessment will be documented in the CADD.

\subsubsection{Accuracy for Radiological Analysis}

Accuracy for radiochemical analyses will be evaluated based on results from LCS and MS samples. The LCS sample is analyzed with the field samples using the same sample preparation, reagents, and analytical methods employed for the samples. One LCS will be prepared with each batch of samples for analysis by a specific measurement.

The MS samples are analyzed to determine if the measurement accuracy is affected by the sample matrix. The MS samples are analyzed with sample batches, when requested.

The percent recovery criteria to be used for assessment of accuracy will be the control limits for radiochemical analyses listed in Table 3-3.

The criteria to evaluate analytical method performance for accuracy will be assessed based on the analytical method-specific (e.g., gamma spectroscopy) accuracy measurements. Each analytical method-specific accuracy performance will be assessed for potential impacts on meeting site characterization objectives, and results of the assessment will be documented in the CADD.

\subsubsection{Representativeness}

Representativeness is the degree to which sample data accurately and precisely represents a characteristic of a population, parameter variations at a sampling point, or an environmental condition (EPA, 1987). Representativeness is assured by a carefully developed sampling strategy, collecting 
the specified number of samples from proper sampling locations, and analyzing them by the approved analytical methods. An evaluation of this qualitative criterion will be presented in the CADD.

\subsubsection{Completeness}

Completeness is a quantitative and qualitative evaluation of measurement system performance. The criterion for meeting completeness is defined as generating sufficient data of the appropriate quality to satisfy the data needs identified in the DQOs. The quantitative measurement to be used to evaluate completeness is presented in Table 6-1 and is based on the percentage of measurements made that are judged to be valid. If these criteria are not achieved, the dataset will be assessed for potential impacts on meeting site characterization objectives.

The qualitative criterion for evaluation of measurement system performance is that sufficient data of the appropriate quality have been generated to satisfy the data needs identified in the DQOs. An evaluation of this qualitative criterion will be presented in the CADD.

\subsubsection{Comparability}

Comparability is a qualitative parameter expressing the confidence with which one dataset can be compared to another (EPA, 1987). To ensure comparability, all samples will be subjected to the same sampling, handling, preparation, analysis, reporting, and validation criteria. Approved standard methods and procedures will also be used to analyze and report the data (e.g., Contract Laboratory Program [CLP] and/or CLP-like data packages). This approach ensures that the data from this project can be compared to regulatory action levels. An evaluation of this qualitative criterion will be presented in the CADD.

\subsubsection{Sensitivity}

Sensitivity is the capability of a method or instrument to discriminate between measurement responses representing different levels of the variable of interest (EPA, 2001a). The evaluation criteria for this parameter will be that measurement sensitivity (detection limits) will be less than or equal to the corresponding PALs. If this criterion is not achieved, the affected data will be assessed for usability and potential impacts on meeting site characterization objectives. 
To ensure that the MRLs are consistent with the corresponding PALs, the MRLs from requested analytical methods for each COPC are compared to the EPA Region 9 PRGs. Equally, the MDCs from radiochemistry analytical methods are compared with the accepted established PALs based on NCRP (1999) and DOE (1993) established levels.

\subsection{Radiological Survey Quality Assurance}

Radiological surveys will be performed and data collected in accordance with approved standard operating procedures. 


\subsection{Duration and Records Availability}

\subsection{Duration}

After the submittal of the CAIP to NDEP (FFACO milestone date of June 1, 2004), the following is a tentative schedule of activities (in calendar days):

- Day 0: Preparation for field work will begin.

- Day 137: The field work, including sample collection activities, will commence. Samples will be shipped to meet laboratory holding times.

- Day 189: The field investigation will be completed.

- Day 403: The quality-assured laboratory analytical data will be available for NDEP review.

- The FFACO date for the CADD has not been established; however, the planned date is October 24, 2005.

\subsection{Records Availability}

Historic information and documents referenced in this plan are retained in the NNSA/NSO project files in Las Vegas, Nevada, and can be obtained through written request to the NNSA/NSO Project Manager. This document is available in the DOE public reading facilities located in Las Vegas and Carson City, Nevada, or by contacting the appropriate DOE Project Manager. The NDEP maintains the official Administrative Record for all activities conducted under the auspices of the FFACO. 


\subsection{References}

ARL/SORD, see Air Resources Laboratory/Special Operations and Research Division.

ASTM, see American Society for Testing and Materials.

Air Resources Laboratory/Special Operations and Research Division. 2003. Air Resources Laboratory/Special Operations and Research Division web site. As accessed at www.sord.nv.doe.gov/arlsord-1 on 3 February.

American Society for Testing and Materials. 1996. Section 04.08 and 04.09, "Soil and Rock, and Construction." In the Annual Book of ASTM Standards. Philadelphia, PA.

American Society for Testing and Materials. 1998. Standard Method for Laboratory Determination of Water (Moisture) Content of Soil, Rock, and Soil-Aggregate Mixtures, D2216. Philadelphia, PA.

American Society for Testing and Materials. 2000a. Standard Test Method for Radiochemical Determination of Plutonium in Soil by Alpha Spectroscopy, C1001-2000. Philadelphia, PA.

American Society for Testing and Materials. 2000b. Standard Test Method for Strontium-90 in Water, D5811-2000. Philadelphia, PA.

American Society for Testing and Materials. 2002a. Standard Test Method for Isotopic Uranium in Water by Radiochemistry, D3972-2002. Philadelphia, PA.

American Society for Testing and Materials. 2002b. Standard Test Method for Plutonium in Water, D3865-02. Philadelphia, PA.

American Society for Testing and Materials. 2002c. Standard Test Method for Radiochemical Determination of Uranium Isotopes in Soil by Alpha Spectroscopy, C1000-2000.

Philadelphia, PA.

BN, see Bechtel Nevada.

Barth, D., U.S. Environmental Protection Agency (Retired). 2003. Telecon with A. Steed (SAIC) and B. Iverson (GeoTrans) regarding the EPA Farm, 13 February. Las Vegas, NV.

Bechtel Nevada. Date Unknown a. Engineering drawing SK-006-03-C11 entitled, "CP and Yucca Lake Area Existing Sewage Systems Site Plan.” Las Vegas, NV. 
Bechtel Nevada. Date Unknown b. Engineering drawing JS-015-06-M4 entitled, "Nevada Test Site Area 15 Demolition Plans CAU 95 EPA Farm Building 15-06 Soil, Waste and Vent Plan." Mercury, NV: Archives and Records Center.

Bechtel Nevada. Date Unknown c. Engineering drawing JS-015-06-C1 entitled, "Nevada Test Site Area 15, Demolition Plans CAU 95 EPA Farm Building 15-06 Site Plan,” Las Vegas, NV.

Bechtel Nevada. 1995. Nevada Test Site Performance Objective Criteria for Certification of Nonradioactive Hazardous Waste, Rev. 0, G-E11/96.01. Las Vegas, NV.

Bechtel Nevada. 1996. Engineering drawing JS-015-139-E1 entitled, "Nevada Test Site - Area 15, NTS Retrofit Power Metering System In-House Energy Management Systems (Phase 1B) Plans, Elevation \& Diagram.” Las Vegas, NV.

Bechtel Nevada. 1998. Engineering drawing FWR-98223-A06-M1 entitled, "Decon Shower Decontamination Facility Bldg 605 Demolition and Floor Plan,” 3 November. Las Vegas, NV.

Betrand, K., Bechtel Nevada. 2003. Record of Telecon with B. Bailey (Shaw) regarding CAS 06-07-01, 2 June. Las Vegas, NV.

Bicker, A.E., Reynolds Electrical \& Engineering Co., Inc. 1988. Memorandum to B.P. Smith (REECo) entitled, "Control of Effluent from Building 650 and the Area 6 Decontamination Facility," 17 November. Las Vegas, NV.

Bingham, F.E., Reynolds Electrical \& Engineering Co., Inc. 1992. Letter to J.D. Stewart (DOE/NTSO) entitled, "Survey of Nevada Test Site (NTS) Abandoned Septic Tank Systems Tiger Team Finding SW/CF-3," 2 January. Las Vegas, NV.

Bingham, F.E., Reynolds Electrical \& Engineering Co., Inc. 1993. Letter to D.R. Elle (DOE/NV) entitled, "Closure of Tiger Team Finding SW/CF-06," 7 July. Las Vegas, NV.

Boehlecke, R.F., Science Applications International Corporation. 1997. Electronic transmittal to E. Shupp (IT) entitled, "MSDS's." Las Vegas, NV.

Boyd, G., Bechtel Nevada. 2003. Record of Telecon with A. Steed (SAIC) regarding CAS 06-07-01, 17 March. Las Vegas, NV.

CFR, see Code of Federal Regulations.

Code of Federal Regulations. 2003a. Title 40 CFR, "Protection of the Environment," Parts 260-282, "Hazardous Waste Management." Washington, DC: U.S. Government Printing Office.

Code of Federal Regulations. 2003b. Title 40 CFR, "Protection of the Environment," Part 761, "Polychlorinated Biphenyls." Washington, DC: U.S. Government Printing Office. 
Code of Federal Regulations. 2003c. Title 40 CFR, "Protection of the Environment," Part 763, “Asbestos.” Washington, DC: U.S. Government Printing Office.

DOE, see U.S. Department of Energy.

DOE/NV, see U.S. Department of Energy, Nevada Operations Office.

DRI, see Desert Research Institute.

Desert Research Institute. 1988. CERCLA Preliminary Assessment of DOE's Nevada Operations Office Nuclear Weapons Testing Areas, Volume I. Prepared for U.S. Department of Energy, Nevada Operations Office. Las Vegas, NV: Water Resources Center.

Desert Research Institute. 1994. A Class III Cultural Resource Reconnaissance of a Proposed Soil Treatability Pilot Plant Site at the EPA Farm, Area 15, Nevada Test Site, Nye County, Nevada, SR090893-1. Prepared by N.G. Goldenberg, W.G. Johnson, and A.R. McLane. Las Vegas, NV.

Desert Research Institute. 1996. Nevada Test Site Water Supply Wells. Prepared for the U.S. Department of Energy, Nevada Operations Office. Las Vegas, NV: Water Resources Center.

EPA, see U.S. Environmental Protection Agency.

ERDA, see U.S. Energy Research and Development Administration.

Edward B. Hendricks Associates. 1965a. Engineering drawing NV-35-08-01.2 entitled, “Area 15 U.S.P.H.S. Field Research Complex Laboratory Mech-Elect. Plot Plan,” 29 November. Mercury, NV: Archives \& Records Center.

Edward B. Hendricks Associates. 1965b. As-built engineering drawing NV-35-08-01.2 Sheet M-2 entitled, “Area 15 N.T.S. U.S.P.H.S. Field Research Complex Laboratory Plumbing Plan," 30 November. Las Vegas, NV.

Edward B. Hendricks Associates. 1965c. As-built engineering drawing NV-35-08-01.1 Sheet A-1 entitled, "Area 15 N.T.S. U.S.P.H.S. Field Research Complex Plan,” 2 December. Las Vegas, NV.

EG\&G Rocky Flats. 1991. General Radiochemistry and Routine Analytical Services Protocol (GRASP), Version 2.1, July. Golden, CO.

Elle, D.R., U.S. Department of Energy, Nevada Operations Office. 1994. Letter to P.J. Liebendorfer (NDEP) entitled, "Summary of Activities at the Area 6 Decontamination (A-6 Decon) Laundry Facility," 19 April. Las Vegas, NV.

FFACO, see Federal Facility Agreement and Consent Order. 
Federal Facility Agreement and Consent Order. 1996 (as amended). Agreed to by the State of Nevada, the U.S. Department of Energy, and the U.S. Department of Defense.

Franky, C. Stoller-Navarro Joint Venture. 2003. Communication to A. Wickline (Stoller-Navarro Joint Venture) regarding evaluation of CAU 543 for listed constituents, 9 December. Las Vegas, NV.

Frazier, A.R., Reynolds Electrical \& Engineering Co., Inc. 1987. Letter to W. McCurry (NDEP) entitled, "Description of NTS and TTR Septic Tank and Leachfield Systems," 21 December. Las Vegas, NV.

Giles, K., Desert Research Institute. 2003. Telecon with A. Steed (SAIC) and B. Iverson (GeoTrans) regarding the EPA Farm, 6 February. Las Vegas, NV.

Holmes \& Narver, Inc. 1971a. Engineering drawing 006-029-C2 entitled, "Rad-Safe Decontamination Laundry Plot Plan,” 23 December. Las Vegas, NV.

Holmes \& Narver, Inc. 1971b. Engineering drawing 006-029-M10 entitled, "Rad-Safe Decontamination Laundry Sanitation \& Waste Drainage Plan," 23 December. Las Vegas, NV.

Holmes \& Narver, Inc. 1971c. Engineering drawing 015-094-C3.7, Sheet 6 of 10 entitled, "Nevada Test Site - Area 15, Modifications to Bldg. 15-06 - USPHS Farm Plan, Profile, and Details," 17 June. Las Vegas, NV.

Holmes \& Narver, Inc. 1972a. Engineering drawing 015-094-C3.2 entitled, "Nevada Test Site - Area 15, Modifications to Bldg. 15-06 - USPHS Farm, Plan, Profile \& Details,” 2 January. Las Vegas, NV

Holmes \& Narver, Inc. 1972b. Engineering drawing 015-06-M1.1, Sheet 5 entitled, "Nevada Test Site - Area 15, Modifications to Bldg. 15-06 - USPHS Farm Plans - Water \& Drainage Piping," 2 January. Las Vegas, NV.

Holmes \& Narver, Inc. 1973a. Engineering drawing 015-06-C1 entitled, "Nevada Test Site Area 15 New EPA Slaughter Facility Grading Plan,” 24 August. Mercury, NV.

Holmes \& Narver, Inc. 1973b. Engineering drawing 015-06-M2.1 entitled, "Nevada Test Site Area 15 New EPA Slaughter Facility Plumbing Plan \& Sections," 24 August. Mercury, NV.

Holmes \& Narver, Inc. 1974. Engineering drawing 015-06-M2.1 entitled, "Nevada Test Site-Area 15, New EPA Slaughter Facility, Plumbing Plan \& Sections,” 6 September. Las Vegas, NV.

Holmes \& Narver, Inc. 1979a. Engineering drawing Page No. 21 entitled, “Area 15 Environmental Protection Agency," 1 April. Las Vegas, NV. 
Holmes \& Narver, Inc. 1979b. Engineering drawing JS-015-06-M2 entitled, “Title II EPA Farm Slaughter Facility Mods Water Piping Plan \& Details," 1 March. Las Vegas, NV.

Holmes \& Narver, Inc. 1981. Engineering drawing 006-029-M10.1 entitled, "Rad-Safe Decontamination Laundry Sanitation \& Waste Drainage Plan," 3 May. Las Vegas, NV.

Hopper, R., U.S. Environmental Protection Agency and S. Helleman, D.B. Stephens. 1995. Record of Telecon with L. Tryboski (IT Corporation) regarding the EPA Farm, 3 August. Las Vegas, NV.

Hopper, D., U.S. Environmental Protection Agency. 2003. Meeting with A. Steed (SAIC) and B. Iverson (Geo Trans) regarding the EPA Farm, 4 February. Las Vegas, NV.

Moore, J., Science Applications International Corporation. 1999. Memorandum to M. Todd (Science Applications International Corporation) entitled, "Background Concentrations for NTS and TTR Soil Samples," 3 February. Las Vegas, NV.

NAC, see Nevada Administrative Code.

NBMG, see Nevada Bureau of Mines and Geology.

NCRP, see National Council on Radiation Protection and Measurements

NNSA/NV, see U.S. Department of Energy, National Nuclear Security Administration Nevada Operations Office.

National Council on Radiation Protection and Measurements. 1999. Recommended Screening Limits for Contaminated Surface Soil and Review of Factors Relevant to Site-Specific Studies, NCRP Report No. 129. Washington, DC.

Nevada Administrative Code. 2002a. NAC 444.570 - 444.7499, "Solid Waste Disposal." Carson City, NV.

Nevada Administrative Code. 2002b. NAC 444.850 - 444.8746, "Disposal of Hazardous Waste." Carson City, NV.

Nevada Administrative Code. 2002c. NAC 444.940 - 444.9555, "Polychlorinated Biphenyls." Carson City, NV.

Nevada Administrative Code. 2002d. NAC 444.965 - 444.976, "Disposal of Asbestos." Carson City, NV.

Nevada Administrative Code. 2003. NAC 445A, "Water Controls.” Carson City, NV. 
Nevada Bureau of Mines and Geology. 1972. Geology and Mineral Deposits of Southern Nye County, Nevada, Bulletin 77. Prepared by H.R. Cornwall. Reno, NV: Mackay School of Mines, University of Nevada, Reno.

Nevada Bureau of Mines and Geology. 1998. Mineral and Energy Resource Assessment of the Nellis Air Force Range, Open-File Report 98-1. Reno, NV.

Nevada Division of Environmental Protection. 1997a. Class II Solid Waste Disposal Site for Municipal and Industrial Solid Waste, Area 23 of the NTS, Permit SW 1309704. Carson City, NV.

Nevada Division of Environmental Protection. 1997b (as amended in August 2000). Class III Solid Waste Disposal Site for Hydrocarbon Burdened Soils, Area 6 of the NTS, Permit SW 1309702. Carson City, NV.

Nevada Division of Environmental Protection. 1997c (as amended in August 2000). Class III Solid Waste Disposal Site; U10C, Area 9 of the NTS, Permit SW 13097 03. Carson City, NV.

Nevada Division of Environmental Protection. 1999. State of Nevada Water Pollution Control General Permit, No. GNEV93001. Carson City, NV.

Nevada Revised Statutes. 2003a. NRS 444.440 - 444.620, "Collection and Disposal of Solid Waste." Carson City, NV.

Nevada Revised Statutes. 2003b. NRS 459.400 - 459.600, "Disposal of Hazardous Waste." Carson City, NV.

Nevada Revised Statutes. 2003c. NRS 618.750 - 618.840. "Disposal of Hazardous Waste.” Carson City, NV.

Nicosia, W.C., Shaw Environmental, Inc. 2003. Memorandum to M. England (SAIC) entitled, "Radiological Land Area Surveys of Various Locations at the Nevada Test Site for Preliminary Assessments," 3 March. Las Vegas, NV.

Olsen, A., Bechtel Nevada. 1997. Correspondence to L. Tryboski (IT Corporation) regarding CAUs at the EPA Farm Facility, 5 August. Las Vegas, NV.

PNNL, see Pacific Northwest National Laboratory.

Pacific Northwest National Laboratory. 2002. "Version 2.0 Visual Sample Plan (VSP): Models and Code Verification." Prepared for the U.S. Environmental Protection Agency. Richland, WA.

Paar, J.G., and D.R. Porterfield. 1997. Evaluation of Radiochemical Data Usability, April, $\mathrm{ES} / \mathrm{ER} / \mathrm{MS}-5$. 
Paradis, L., Company Unknown. 1998. Record of Telecon with L.M. Mercado regarding the status of the Area 6 decon pad, 4 August. Las Vegas, NV.

REECo, see Reynolds Electrical \& Engineering Co., Inc.

RSL, see Remote Sensing Laboratory.

RSN, see Raytheon Services Nevada.

Radack, P.M., Reynolds Electrical \& Engineering Co., Inc. 1992. Memorandum to M.B. Brown (REECo) entitled, "Decontamination Facility Septic Tank," 2 June. Las Vegas, NV.

Raytheon Services Nevada. 1992. Engineering drawing JS-006-083-C2 entitled, "Area 6 Yucca Lake Utilities - Water Map,” 29 December. Las Vegas, NV.

Reynolds Electrical \& Engineering Co., Inc. 1971a. Ground-level photograph 3296-06 showing Building 6-605, 4 February. Nellis Air Force Base, NV: Remote Sensing Laboratory Photo Library.

Reynolds Electrical \& Engineering Co., Inc. 1971b. Environmental Sciences Decontamination Facility Operations Guide, September. Mercury, NV.

Reynolds Electrical \& Engineering Co., Inc. 1973. Engineering drawing SK-6-183 entitled, "Decon Facility Drainage Control Grading Plan,” 15 February. Las Vegas, NV.

Reynolds Electrical \& Engineering Co., Inc. 1975a. Engineering Drawing, 15-E.P.A.-C1 entitled, "Nevada Test Site - Area 15, E.P.A. Farm Contaminated Waste Disposal System Modification Plan \& Profile - Sections - Details," 10 June. Las Vegas, NV.

Reynolds Electrical \& Engineering Co., Inc. 1975b. Engineering drawing 15-E.P.A.-E1 entitled, "Nevada Test Site - Area 15, E.P.A. Farm Contaminated Waste Disposal System Elect. Plan Diagram \& Details," 11 June. Las Vegas, NV.

Reynolds Electrical \& Engineering Co., Inc. 1979a. Engineering drawing 6-DD-C1 entitled, "Dyna-Drill Maintenance Shop Plot \& Utility Plan," 29 September. Las Vegas, NV.

Reynolds Electrical \& Engineering Co., Inc. 1979b. Engineering drawing 6-D-A1 entitled, "Rad-Safe Decontamination Facility Architectural - Floor Plan," 5 July. Las Vegas, NV.

Reynolds Electrical \& Engineering Co., Inc. 1979c. Engineering drawing 6-D-S2 entitled, "Rad-Safe Decontamination Facility Floor Slab Drainage Plan \& Sections,” 5 July. Las Vegas, NV.

Reynolds Electrical \& Engineering Co., Inc. 1979d. Engineering drawing 6-D-A2 entitled, "Rad-Safe Decontamination Facility Partial Floor Plan, Sect. \& Det’s," 5 July. Las Vegas, NV. 
Reynolds Electrical \& Engineering Co., Inc. 1979e. Engineering drawing 6-D-M3 entitled, "Rad-Safe Decontamination Facility Plumbing Layout \& Schedule," 5 July. Las Vegas, NV.

Reynolds Electrical \& Engineering Co., Inc. 1979f. Engineering drawing 6-D-M1 entitled, "Rad-Safe Decontamination Facility Piping Layout \& Legend," 2 July. Las Vegas, NV.

Reynolds Electrical \& Engineering Co., Inc. 1985. Engineering drawing 6-605-C1 entitled, "Reline Concrete Drains Decon Facility Bldg 6-605,” 16 April. Las Vegas, NV.

Reynolds Electrical \& Engineering Co., Inc. 1994a. Engineering drawing 6-605-556-S5.1 entitled, "Concrete Floor Repair Decon Facility, Building 6-605 Existing Floor Plan," 10 November. Las Vegas, NV.

Reynolds Electrical \& Engineering Co., Inc. 1994b. Engineering drawing 6-605-556-S6.1 entitled, "Concrete Floor Repair Decon Facility, Building 6-605 Floor Plan," 7 September. Las Vegas, NV.

Reynolds Electrical \& Engineering Co., Inc. 1994c. Engineering drawing 6-605-556-S9.1 entitled, "Recirculation Tank System Decon Facility, Building 6-605 Floor Plan," 11 July. Las Vegas, NV.

Reynolds Electrical \& Engineering Co., Inc. 1994d. Engineering drawing 6-DF-556-C11.1 entitled, "Upper Wastewater Disposal System Decon Facility, Area 6 Site Plan,” 29 October. Las Vegas, NV.

Reynolds Electrical \& Engineering Co., Inc. 1994e. Engineering drawing 6-DF-556-C3.2 entitled, "Sanitary Sewerage System Decon Facility, Area 6 Site Plan," 27 October. Las Vegas, NV.

Reynolds Electrical \& Engineering Co., Inc. 1994f. Engineering drawing 6-DF-556-10.1 entitled, "Upper Wastewater Disposal System Decon Facility, Area 6 existing/Demolition Plan," 5 October. Las Vegas, NV.

SAIC, see Science Applications International Corporation.

Shaw, see Shaw Environmental, Inc.

SNJV, see Stoller-Navarro Joint Venture.

SWRHL, see Southwestern Radiological Health Laboratory.

Science Applications International Corporation. 2003. Surface Geophysical Survey Final Report Corrective Action Units Nevada Test Site, May. Prepared for Shaw Environmental, Inc. Harrisburg, PA.

Shaw Environmental, Inc. 2003. CAU 543 Project File. Las Vegas, NV. 
Shott, G.J., V. Yucel, M.J. Sully, L.E. Barker, S.E. Rawlinson, and B.A. Moore. 1997. Performance Assessment/Composite Analysis for the Area 3 Radioactive Waste Management Site at the Nevada Test Site, Nye County, Nevada, Rev. 2.0. Las Vegas, NV.

Smith, M. 1991. Site Monitoring/Site Demarcation Checklist: Area 15 Site Dry Well-Feed Storage Bin, 29 May. Las Vegas, NV.

Soil Science Society of America. 1980. "A Closed Form Equation for Predicting the Hydraulic Conductivity of Unsaturated Soils.” In Soil Science Society of America Journal, Vol 44. Madison, WI.

Soil Science Society of America. 1986. "Methods of Soil Analysis," 2nd Edition, Part 1. Madison, WI.

Soong, C., Bechtel Nevada. 2003. Record of Telecon with B. Bailey (Shaw) regarding CAS 06-07-01, 9 June. Las Vegas, NV.

Sorom, E., Reynolds Electrical \& Engineering Co., Inc. 1995. Telecon with L. Tryboski (IT Corporation) regarding the tank at the EPA Farm, 13 July. Las Vegas, NV.

Southwestern Radiological Health Laboratory. 1967. Status of the Nevada Test Site Experimental Farm Summary Report for July 1964-December 1965, SWRHL-36r. Prepared by R.L. Douglas for the U.S. Atomic Energy Commission. Las Vegas, NV.

Stoller-Navarro Joint Venture. 2003. Site-Specific Health and Safety Plan. Las Vegas, NV.

USACE, see U.S. Army Corps of Engineers.

USC, see United States Code.

USGS, see U.S. Geological Survey.

U.S. Army Corps of Engineer. 1970. "Laboratory Soils Testing.” In Engineering Manual 1110-2-1906, Appendix II. Washington, DC.

United States Code. 1976. 15 USC 2601 et seq., "Toxic Substances Control Act." Enacted by Public Law No. 94-469, as amended. Washington, DC: U.S. Government Printing Office.

U.S. Department of Energy. 1988. Environmental Survey Preliminary Report, DOE/EH/OEV-15P, April. Washington, DC: Environment, Safety, and Health Office of Environmental Audit.

U.S. Department of Energy. 1993. DOE Order 5440.5, Change 2, Radiation Protection of the Public and the Environment. Washington, DC: U.S. Government Printing Office. 
U.S. Department of Energy. 1997. The Procedures Manual of the Environmental Measurements Laboratory Procedures Manual, HASL-300, 28th Ed., Vol. I. New York, NY.

U.S. Department of Energy, National Nuclear Security Administration Nevada Operations Office. 2002. Industrial Sites Quality Assurance Project Plan, Nevada Test Site, Nevada, Rev. 3, DOE/NV--372. Las Vegas, NV.

U.S. Department of Energy, National Nuclear Security Administration Nevada Site Office. 2003. Nevada Test Site Waste Acceptance Criteria, DOE/NV--325, Rev. 5. Las Vegas, NV.

U.S. Department of Energy, Nevada Operations Office. 1984. Safety Assessment of the Area 6 Decontamination Pad and Laundry, DOE/NV/10327-12. Prepared by M.W. Chilton and J.A. Orcutt. Las Vegas, NV.

U.S. Department of Energy, Nevada Operations Office. 1992. RCRA Part B Permit Application for Waste Management Activities at the Nevada Test Site: Section L Potential Solid Waste Management Units, Volume IV. Las Vegas, NV.

U.S. Department of Energy, Nevada Operations Office. 1993. Nevada Test Site Conceptual Site Treatment Plan, October. Las Vegas, NV.

U.S. Department of Energy, Nevada Operations Office. 2000. Nevada Test Site Contaminated Land Areas Report, Volume I, DOE/NV/11718-481-VOL 1. Las Vegas, NV.

U.S. Department of Energy, Nevada Operations Office. 1994a. Project Management Plan, Rev. 0. Las Vegas, NV.

U.S. Department of Energy, Nevada Operations Office. 1994b. Resource Conservation and Recovery Act Site Characterization Plan Area 6 Decontamination Pond Facility, January. Las Vegas, NV.

U.S. Department of Energy, Nevada Operations Office. 1995. Preliminary Characterization of Abandoned Septic Tank Systems, DOE/NV-414 UC-700. Volume I and II. Prepared by Reynolds Electrical \& Engineering Co., Inc. Las Vegas, NV.

U.S. Department of Energy, Nevada Operations Office. 1996. Final Environmental Impact Statement for the Nevada Test Site and Off-Site Locations in the State of Nevada, DOE/EIS 0243. Las Vegas, NV.

U.S. Department of Energy, Nevada Operations Office. 1997. Integrated Safety Management Policy, DOE Order NV P 450.4. Las Vegas, NV.

U.S. Department of Energy, Nevada Operations Office. 1998a. Closure Report for Decontamination \& Decommissioning (D\&D) Category, Corrective Action Unit 95, EPA Farm Laboratory Building 15-06, Nevada Test Site, DOE/NV-11718-178. Las Vegas, NV. 
U.S. Department of Energy, Nevada Operations Office. 1998b. Nevada Test Site Resource Management Plan, DOE/NV-518. Las Vegas, NV.

U.S. Department of Energy, Nevada Operations Office. 1999. Closure Report for Corrective Action Unit 92: Area 6 Decontamination Pond Nevada Test Site, Nevada, DOE/NV/11718-306. April. Las Vegas, NV.

U.S. Department of Energy, Nevada Operations Office. 2000a. Closure Report for Petroleum Hydrocarbon Release at the Area 6 Decontamination Facility at the Nevada Test Site: Tank 6-605-1 (NDEM \#990204-3304), February. Las Vegas, NV.

U.S. Department of Energy, Nevada Operations Office. 2000b. NV/YMP Radiological Control Manual, Rev. 5, DOE/NV/11718-079. Prepared by A.L. Gile of Bechtel Nevada. Las Vegas, NV.

U.S. Department of Energy, Nevada Operations Office. 2000c. Nevada Test Site Annual Site Environmental Report for Calendar Year - 1999, DOE/NV11718-463. Las Vegas, NV.

U.S. Environmental Protection Agency. 1973. Status of the Environmental Protection Agency's Nevada Test Site Experimental Dairy Herd January 1, 1969 - December 31, 1970, NERC-LV-539-22. Prepared by D.D. Smith for the U.S. Atomic Energy Commission. Las Vegas, NV.

U.S. Energy Research and Development Administration. 1976. Letter to H.D. Cunningham transmitting the attachment "Disposal Procedures for Contaminated Liquid Waste EPA Farm," Accession numbers NVO173551 and NVO173552, September. Las Vegas, NV: NNSA/NSO Public Reading Facility.

U.S. Energy Research and Development Administration. 1977. Final Environmental Impact Statement, Nevada Test Site, Nye County, Nevada, ERDA-1551. Washington, DC.

U.S. Environmental Protection Agency. 1980. Prescribed Procedures for Measurement of Radioactivity in Drinking Water, EPA 600/4-80-032 (NTIS/PB80-224744; CD ROM; NEPIS/http://www.epa.gov/cincl). Prepared by H.L. Krieger and E.K. Whittaker. Cincinnati, $\mathrm{OH}$.

U.S. Environmental Protection Agency. 1987. Data Quality Objectives for Remedial Response Activities, EPA/540/G-87/003. Washington, DC.

U.S. Environmental Protection Agency. 1988a. Contract Laboratory Program Statement of Work for Inorganic Analysis, SOW No. 788, EPA/540/R-94/093. Washington, DC.

U.S. Environmental Protection Agency. 1988b. Contract Laboratory Program Statement of Work for Organic Analysis, SOW No. 2/88, EPA/540/R-94/096. Washington, DC. 
U.S. Environmental Protection Agency. 1991. Contract Laboratory Program Statement of Work for Organic Analysis, OLMO 1.8, EPA/540/R-94/078. Washington, DC.

U.S. Environmental Protection Agency. 1994a. Contract Laboratory Program National Functional Guidelines for Inorganic Data Review, EPA/540/R-94/013. Washington, DC.

U.S. Environmental Protection Agency. 1994b. Contract Laboratory Program Statement of Work for Inorganic Analysis, ILMO 3.0, EPA/540/R-94/076. Washington, DC.

U.S. Environmental Protection Agency. 1994c. Contract Laboratory Program Statement of Work for Organic Analysis, OLMO 3.1, EPA/540/R-94/073. Washington, DC.

U.S. Environmental Protection Agency. 1995. Contract Laboratory Program Statement of Work for Inorganic Analysis, ILMO 4.0, EPA/540/R-95/121. Washington, DC.

U.S. Environmental Protection Agency. 1996. Test Method for Evaluating Solid Waste Physical/Chemical Methods, SW-846, 3rd Edition, CD-ROM PB97-501928GEI. Washington, DC.

U.S. Environmental Protection Agency. 1999. Contract Laboratory Program National Functional Guidelines for Organic Data Review, EPA 540/R-99/008. Washington, DC.

U.S. Environmental Protection Agency. 2002. Region IX Preliminary Remediation Goals (PRGs). Prepared by S.J. Smucker. San Francisco, CA.

U.S. Environmental Protection Agency. 2003. Integrated Risk Information System (IRIS) Database. As accessed at http://www.epa.gov/iris/index.html on 27 February.

U.S. Geological Survey. 1965. Records of Wells and Test Holes at the Nevada Test Site and Vicinity Since 1960, Technical Letter: NTS-117. Prepared by R.A. Young. Denver, CO.

U.S. Geological Survey. 1968. "Surficial Deposits of Yucca Flat Area, Nevada Test Site," in Nevada Test Site. Prepared by A.T. Fernald, G.S. Corchary, W.P. Williams, and R.B. Colton. Washington, DC.

U.S. Geological Survey. 1975. Hydrogeologic and Hydrochemical Framework, South-Central Great Basin, Nevada-California, with Special Reference to the Nevada Test Site, USGS-PR-712-C. Prepared by I.J. Winogard and W. Thordarson on behalf of the U.S. Atomic Energy Commission. Denver, CO.

U.S. Geological Survey. 1985. Inflow to a Crack in Playa Deposits of Yucca Lake, Nevada Test Site, Nye County, Nevada. Prepared by G.C. Doty and F.E. Rush. Denver, CO.

U.S. Geological Survey. 1990. Geologic Map of the Nevada Test Site, Southern Nevada, USGS Map I-2046. Denver, CO. 
U.S. Geological Survey. 1996. Summary of Hydrogeologic Controls on Ground-Water Flow at the Nevada Test Site, Nye County, Nevada, WRIR96-4109. Prepared by R.J. Laczniak, J.C. Cole, D.A. Sawyer, and D.A. Trudeau. Carson City, NV.

U.S. Geological Survey and U.S. Department of Energy. 2003. USGS/DOE Cooperative Studies in Nevada Water-Levels Well Site Map Page. As accessed at http://nevada.usgs.goe/doe_nv/wateruse/wumap.asp on 2 January.

Western, A.W., Reynolds Electrical \& Engineering Co., Inc. 1977. Memorandum to A.E. Bicker (REECo) entitled, "Concrete Floor - Decon Facility,” 28 March. Las Vegas, NV.

Wuellner, J.W., Reynolds Electrical \& Engineering Co., Inc. 1994. Memorandum to E.W. Kendall (REECo) entitled, "Inspection of Buildings 605 and 607," 23 June. Las Vegas, NV. 
Appendix A.1

\section{Data Quality Objectives}




\section{A.1 Data Quality Objectives Process}

The DQO process is a seven-step strategic planning approach based on the scientific method that is being used to plan data collection activities for each CAS within CAU 543, Liquid Disposal Units. The DQOs are designed to ensure that the data collected will provide sufficient and reliable information to identify, evaluate, and technically defend the recommended corrective actions (i.e., no further action, closure in place, or clean closure). Existing information about the nature and extent of contamination at the CASs in CAU 543 is insufficient to evaluate and select preferred corrective actions; therefore, a corrective action investigation will be conducted.

The CAU 543 investigation will be based on DQOs developed in this Appendix by representatives from NDEP and NNSA/NSO. The seven steps of the DQO process developed for the CASs in CAU 543 and presented in Section A.1.2 through Section A.1.8 were developed based on the CAS-specific information presented in Section A.1.1 and in accordance with EPA Guidance for Quality Assurance Project Plans (EPA, 2002a). This document identifies and references the associated EPA Quality System Document for DQOs entitled Data Quality Objectives Process for Hazardous Waste Site Investigations (EPA, 2000a) and Guidance on Choosing a Sampling Design for Environmental Data Collection (EPA, 2000b) upon which the DQO process presented herein is based.

\section{A.1.1 CAS-Specific Information}

Corrective Action Unit 543 contains seven individual CASs. One CAS is located in Area 6 and the other six CASs are located in Area 15 of the NTS as shown in Figure A.1-1. The CASs within CAU 543 are:

- 06-07-01, Decon Pad

- 15-04-01, Septic Tank

- 15-05-01, Leachfield

- 15-08-01, Liquid Manure Tank

- 15-23-03, Contaminated Sump, Piping

- 15-01-03, Aboveground Storage Tank

- 15-23-01, Underground Radioactive Material Area 


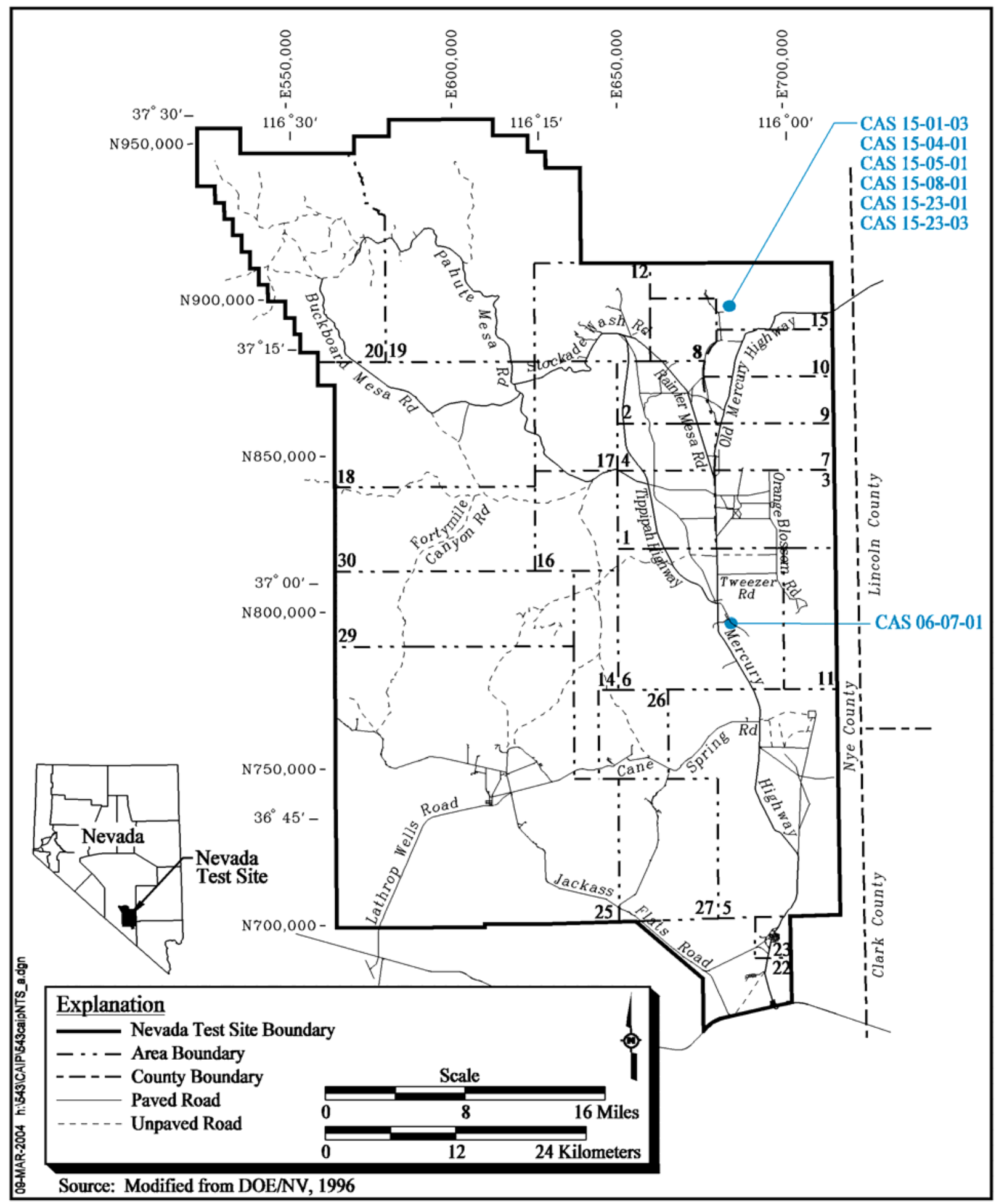

Figure A.1-1

Location of CAU 543 Corrective Action Sites 
Section A.1.1.1 and Section A.1.1.2 provide overviews of the operational histories of the Area 6 Decontamination Facility and the Area 15 EPA Farm, respectively. Processes and activities conducted at each of these separate facilities have created interrelated sources and potential releases common to the CASs or CAS components. Each section is followed by subsections that discuss the CAS or CAS-component physical setting and operational history, sources of potential contamination, any previous investigations, and potential contamination for each CAS.

The CAS-specific critical COPCs are listed in Table A.1-1 and described in the following CAS descriptions. Many of the COPCs are based on process knowledge of activities conducted rather than specific knowledge of a release. As a result, many of the Decision I COPCs for the CAI are considered the class of contaminants for a given analytical suite. Critical COPCs are defined as those contaminants that are known or reasonably suspected to be present within the CAS based on previous sampling, process knowledge, geographic setting, and/or operational site history. Analyses for noncritical COPCs assist in reducing the uncertainty concerning the history and potential release from the CAS and allow for an accurate evaluation of potential contamination. Beryllium, PCBs, and gamma-emitting radionuclides are general COPCs common to every CAS due to process knowledge of the NTS and lack of data to eliminate these from consideration.

\section{A.1.1.1 Area 6 Decontamination Facility}

The Area 6 Decontamination Facility (Figure A.1-2) was built in 1971 and designed to handle mixed and radioactive waste generated from a variety of decontamination processes (DOE/NV, 1984 and 1993; Holmes \& Narver, 1971b). The Area 6 Decontamination Facility is located along the southwest edge of Yucca Lake in Area 6 of the NTS and consisted of several buildings and structures within a fenced area:

- Area 6 Decontamination Pad (Building 6-605) and an associated outdoor concrete pad

- Area 6 Decontamination Laundry (Building 6-607)

- Dyna Drill Repair Shop (Building 6-606)

- Dyna Drill Repair Parts (Building 06-2203A)

- Tent Structure 06-202567

- Trailer TA-20 on a concrete foundation

- An electrical substation

- Various other temporary containers and sheds

- Storage area for contaminated materials 
Table A.1-1

Contaminants of Potential Concern for CAU 543

\begin{tabular}{|c|c|c|c|c|c|c|c|}
\hline \multirow{2}{*}{$\begin{array}{l}\text { Contaminants of } \\
\text { Potential Concern }\end{array}$} & \multirow{2}{*}{$\begin{array}{c}\text { Area } 6 \\
\text { CAS } \\
6-07-01\end{array}$} & \multicolumn{6}{|c|}{ Area 15 - EPA Farm } \\
\hline & & $\begin{array}{c}\text { CAS } \\
15-04-01\end{array}$ & $\begin{array}{c}\text { CAS } \\
15-05-01\end{array}$ & $\begin{array}{c}\text { CAS } \\
15-08-01\end{array}$ & $\begin{array}{c}\text { CAS } \\
15-23-03\end{array}$ & $\begin{array}{c}\text { CAS } \\
15-01-03\end{array}$ & $\begin{array}{c}\text { CAS } \\
15-23-01\end{array}$ \\
\hline Degreasers & $\mathbf{x}$ & & & & & & $x$ \\
\hline Solvents & $\mathbf{x}$ & & & & & & $\mathbf{x}$ \\
\hline Detergents & $\mathbf{x}$ & & & & & & $\mathbf{x}$ \\
\hline Caustics & $\mathbf{x}$ & & & & & & \\
\hline Acids & $x$ & & & & & & \\
\hline Gamma Emitting Radionuclides & $\mathbf{x}$ & $\mathbf{x}$ & $\mathbf{x}$ & $\mathbf{x}$ & $\mathbf{x}$ & $\mathbf{x}$ & $\mathbf{x}$ \\
\hline Cesium-137 & $\mathbf{x}$ & $\mathbf{x}$ & $\mathbf{x}$ & $\mathbf{x}$ & $\mathbf{x}$ & $\mathbf{x}$ & $\mathbf{x}$ \\
\hline Plutonium-238/239 & $\mathbf{x}$ & $\mathbf{x}$ & $\mathbf{x}$ & $\mathbf{x}$ & $\mathbf{x}$ & $\mathbf{x}$ & $\mathbf{x}$ \\
\hline Plutonium-240 & $\mathbf{x}$ & $\mathbf{x}$ & $\mathbf{x}$ & $\mathbf{x}$ & $x$ & $\mathbf{x}$ & $x$ \\
\hline Strontium-90 & $\mathbf{x}$ & $\mathbf{x}$ & $\mathbf{x}$ & $\mathbf{x}$ & $\mathbf{x}$ & $\mathbf{x}$ & $\mathbf{x}$ \\
\hline Americium-241 & $\mathbf{x}$ & $\mathbf{x}$ & $\mathbf{x}$ & $\mathbf{x}$ & $\mathbf{x}$ & $\mathbf{x}$ & $\mathbf{x}$ \\
\hline Uranium-234 & $\mathbf{x}$ & $x$ & $x$ & $\mathbf{x}$ & $x$ & $x$ & $x$ \\
\hline Uranium-235 & $\mathbf{x}$ & $\mathbf{x}$ & $\mathbf{x}$ & $\mathbf{x}$ & $x$ & $\mathbf{x}$ & $\mathbf{x}$ \\
\hline Uranium-238 & $\mathbf{x}$ & $x$ & $\mathbf{x}$ & $\mathbf{x}$ & $x$ & $x$ & $x$ \\
\hline VOCs & $\mathbf{x}$ & $\mathbf{x}$ & $\mathbf{x}$ & $\mathbf{x}$ & $\mathbf{x}$ & $\mathbf{x}$ & $\mathbf{x}$ \\
\hline SVOCs & $\mathbf{x}$ & $x$ & $x$ & $\mathbf{x}$ & $\mathbf{x}$ & $\mathbf{x}$ & $\mathbf{x}$ \\
\hline Metals (Including Beryllium) & $\mathbf{x}$ & $\mathbf{x}$ & $\mathbf{x}$ & $\mathbf{x}$ & $\mathbf{x}$ & $x$ & $x$ \\
\hline TPH & $\mathbf{x}$ & $\mathbf{x}$ & $x$ & $x$ & $\mathbf{x}$ & $x$ & $x$ \\
\hline PCBs & $\mathbf{x}$ & $x$ & $\mathbf{x}$ & $\mathbf{x}$ & $x$ & $\mathbf{x}$ & $x$ \\
\hline Pesticides & & $\mathbf{x}$ & $\mathbf{x}$ & $\mathbf{x}$ & $\mathbf{x}$ & $\mathbf{x}$ & $\mathbf{x}$ \\
\hline Herbicides & & $\mathbf{x}$ & $\mathbf{x}$ & $\mathbf{x}$ & $\mathbf{x}$ & $\mathbf{x}$ & $\mathbf{x}$ \\
\hline Sanitary Waste & $\mathbf{x}$ & $x$ & $\mathbf{x}$ & $x$ & $x$ & $\mathbf{x}$ & \\
\hline Laboratory Wastes & & $x$ & $\mathbf{x}$ & $x$ & $x$ & $x$ & \\
\hline Biological waste & & $x$ & $\mathbf{x}$ & $\mathbf{x}$ & $x$ & $\mathbf{x}$ & \\
\hline
\end{tabular}

Biological waste $=$ Fecal matter, urine, blood, animal organs 


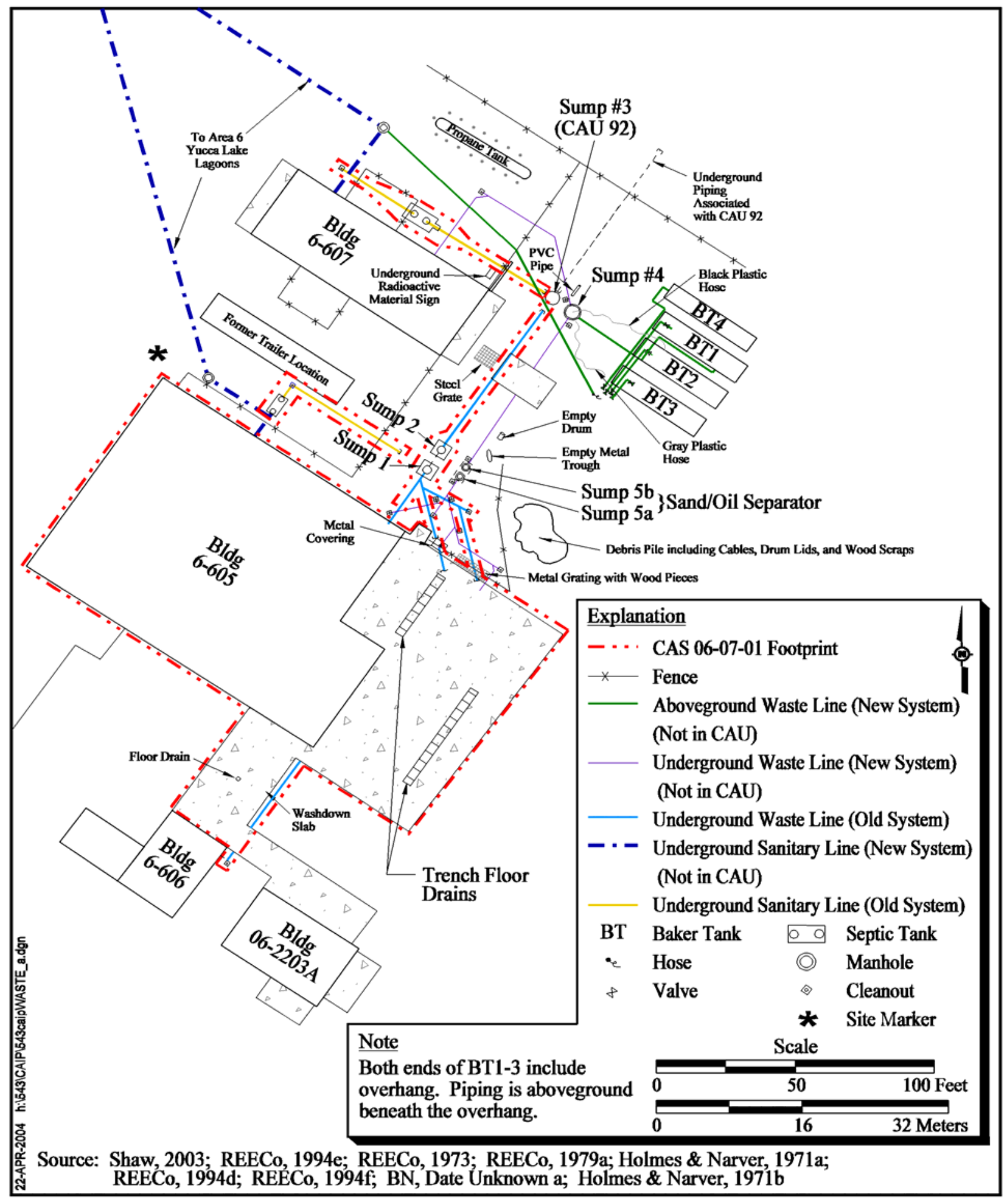

Figure A.1-2

CAU 543, CAS 06-07-01, Decon Pad Site Map 
The Area 6 Decontamination Pond, located $600 \mathrm{ft}$ northeast of the Facility, was the original discharge area for all liquid wastes generated within the Facility buildings until the Pond was closed in 1992 (DOE/NV, 1999). The Area 6 Decontamination Pond, associated piping from the Pond to Sump 3 located within the Facility perimeter fence, and Sump 3 have been remediated and closed under CAU 92 (DOE/NV, 1999).

The Area 6 Decontamination Facility was built to decontaminate vehicles, equipment, and clothing that had become radiologically contaminated during nuclear testing activities (DOE/NV, 1984 and 1993). From 1971 through 1992, hazardous, radioactive, and sanitary wastes were generated within Buildings 6-605, 6-606, 6-607, and Trailer TA-20 and originally discharged via process waste lines, septic systems, and sumps to the Area 6 Decontamination Pond located north of the facility (REECo, 1979a; DOE/NV, 1999). Until November 1988, the waste generated at CAS 06-07-01 contained RCRA constituents; however, after this date, wastes containing RCRA constituents were no longer allowed to be discharged into this waste system (Bicker, 1988). Around 1992, liquid wastes were no longer allowed to be discharged to the Decontamination Pond (Bingham, 1993a). In 1994, the Area 6 Decontamination Facility waste collection/discharge system underwent a significant upgrade in which a new process waste line system and ASTs (i.e., Baker tanks) were installed to contain all liquid wastes generated within the buildings prior to disposal. The sanitary septic tanks were reportedly changed to holding tanks for domestic sewage prior to the new sewer line being installed (Radack, 1992). The Area 6 Decontamination Facility remained operational until approximately 2001 and is currently inactive and abandoned (Soong, 2003).

Building 6-605, built in 1971, is the main decontamination facility and is referred to as the Area 6 Decontamination Pad. The building contains both a high and low bay equipped to accommodate both large (i.e., drill rigs) and smaller vehicles and equipment. The primary decontamination process for radiologically contaminated materials involved spraying water, mixed with cleaning solvents and soaps/detergents, onto contaminated materials inside the bays. Electronic equipment and materials that could be damaged by water were cleaned using solvents, such as alcohol. Three dip tanks, containing hot caustics, were also located within the building and were used to submerge and clean smaller pieces of equipment (REECo, 1971b; DOE/NV, 1984). An outdoor decontamination pad sits adjacent to the building and contains a floor drain. It is assumed decon activities were conducted on this pad as well. The liquid wastes generated by the decontamination activities were collected within 
the floor drains of the building and discharged via a process waste line to the Pond. The building also contained restrooms and personnel decontamination facilities (e.g., showers) that discharged sanitary wastes via a separate sewer line and septic tank before discharging to the Pond.

Building 6-607, the Area 6 Decontamination Laundry, was used to clean clothing and other fabrics contaminated with potentially radioactive and hazardous material from NTS testing activities (Wuellner, 1994). Effluent from the laundry operations was discharged via a process waste line to the Pond, while sanitary effluent from the laundry facility was discharged through an associated sewer line and septic tank before discharging to the Pond.

Building 6-606, the Dyna-Drill Repair Shop, is located south of Building 6-605. The building was used to fix pipes and other drill parts that were decontaminated within the Area 6 Decontamination Facility. Discharges from the Facility entered the process waste line going to the Area 6 Decontamination Pond.

The Dyna-Drill Repair Parts, Building 6-2203A, is located southwest of Building 6-605. The building was used in conjunction with the Dyna-Drill Repair Shop; however, specific activities are unknown (REECo, 1979a). Documentation indicates this building did not contribute or generate a liquid waste stream.

The Trailer TA-20 was an administrative office located northwest of Building 6-605. Activities conducted within this trailer, other than administrative, are unknown. The trailer had an aboveground PVC line that connected directly into Building 6-605 sanitary sewer line and it is believed the trailer discharged only sanitary waste (Radack, 1992). The trailer or PVC piping is no longer present; however, the concrete foundation is.

The Tent Structure, Building 6-202567, is located southwest of Building 6-605 and was used to store various wastes (BN, Date Unknown a). The majority of these wastes were stored in B25 steel boxes. Documentation and process knowledge indicates this building was not directly related to the decontamination activities of Building 6-605; therefore, it did not contribute liquid wastes via a process or sewer waste line. 
The southeast portion of the facility, formerly used to store contaminated materials, is currently posted as a "Contamination Area" (Holmes \& Narver, 1971a).

\section{A.1.1.1.1 CAS 06-07-01, Decon Pad}

The portions of the Area 6 Decontamination Facility piping system that are included in CAS 06-07-01 are those areas that may have been impacted by RCRA or other hazardous constituents from decontamination activities. The entire piping system at the facility underwent significant changes in 1994 after which wastes from Buildings 6-605, potentially 6-606, and 6-607 flowed into sequenced Baker tanks located in the northeast section of the facility (REECo, 1994f; Bertrand, 2003). The last sequenced tank was sampled for RCRA constituents before liquid was allowed to drain to a sanitary sewer manhole located north of Building 6-607 and discharge to the Area 6 Yucca Lake Lagoon System. Since the wastes generated after the upgrades have been analyzed and consistently shown to be nonhazardous (Elle, 1994), the piping, sumps, and tanks installed for the 1994 upgrade are not included in this CAS. However, all portions of the old piping system, including the sumps and septic tanks, are covered as part of CAS 06-07-01.

Physical Setting and Operational History - The portions of CAS 06-07-01 to be investigated under CAU 543 include Building 6-605 and an associated outdoor decontamination pad; portions of the inactive sanitary sewer systems from Buildings 6-605 and 6-607; inactive underground process waste lines and sumps that formerly discharged wastes from Buildings 6-605, 6-606, and 6-607 to the former Area 6 Decontamination Pond, and the soils located in the southeast portion of the Decontamination Facility that was formerly used for the storage of contaminated materials.

Building 6-605, the main decontamination facility, is a slab-on-grade metal building measuring approximately $100 \times 84 \mathrm{ft}$. The building contains a high and low bay capable of accommodating heavy equipment, a dip tank bay containing three heated dip tanks capable of holding pipe stems up to $40 \mathrm{ft}$ in length, a storeroom, a mechanical equipment room, a shower/locker room, and two offices (DOE/NV, 1984). The two bays contain several remaining high-pressure pumps and recirculation tanks (REECo, 1979b and c). The building contains floor drains (most are configured as trenches) that collected various liquids and wastes from decontamination processes occurring inside the building. Currently, the building appears in good condition with no significant spills or staining visible. The dip tanks are still present within the building and believed to be empty. 
The liquids from Building 6-605 drains were piped via a process waste line to two sumps labeled Sump 1 (sand trap) and Sump 2 (oil/water separator) located northeast of Building 6-605 (REECo, 1973). These two sumps were designed to remove the solid and oil components from the liquid waste. Liquid process wastes from Building 6-607 (Laundry) entered the system at Sump 3 via the process waste line, while process waste from Building 6-606 entered the system via the process waste line south of Building 6-605. The liquid then flowed via the process waste line to Sump 3. From Sump 3, wastes were delivered via piping to the Area 6 Decontamination Pond.

Sanitary sewage waste discharged from Buildings 6-605 and 6-607 through separate sewer lines to separate septic tanks. From the Building 6-605 septic tank, the sanitary sewer line ran southeast to Sump 1, joined the process waste line, and then discharged to the Pond. From the septic tank that serviced Building 6-607, the sanitary sewer line joined the process waste line, connected to Sump 3, and then discharged to the Pond (REECo, 1973; Holmes \& Narver, 1981). Trailer TA-20 had a PVC line directly connected to the sewer system at Building 6-605. The PVC line and the trailer have been removed, leaving only the concrete foundation present at the facility. Currently, two metal coverings are present over the Building 6-605 septic tank. Metal grates replaced the two manhole covers over the Building 6-607 septic tank. One manhole cover was noted in the area of Sumps 1 and 2; however, it is not clear which sump was connected to the manhole.

In 1994, a new process waste line system was installed, including new sumps and a new concrete floor in Building 6-605 (REECo, 1994a, b, c, e, and f). The process waste line still originated at the decontamination pad (Building 6-605), but the line continued to Sumps 5a and 5b, and then to Sump 4. From Sump 4, waste was sent to three baker tanks located at the northeast end of the facility. A fourth baker tank was installed sometime later, but it is uncertain if it was ever used. When the last baker tank became full, the wastewater was tested for RCRA hazardous constituents. If all contaminants were below action levels, then the water would be discharged via an aboveground pipe that connected to a sanitary sewer manhole on the north side of Building 6-607 (Bertrand, 2003; Boyd, 2003). Waste entering this manhole was sent to the Area 6 Yucca Lake Lagoon Systems. It is unknown what was done with the water if the action levels were exceeded. These new components included in the reconfigured system are not included in this CAS but are added for knowledge of the current system (Bertrand, 2003; Paradis, 1998). The Baker tanks are still present at the facility. 
Sources of Potential Contamination - Activities conducted at the Area 6 Decontamination Facility included decontaminating vehicles, equipment, and clothing that had become contaminated during nuclear testing activities. Decontamination activities conducted within Building 6-605 created effluent potentially contaminated with cleaning solvents, soaps/detergents, degreasers, hot caustics, acids, and various radionuclides from contaminated materials that were discharged through floor drains to a process waste line system which currently includes subsurface piping and two sumps. Documentation states that due to numerous caustic and acidic spills and abrasive actions caused by drill pipe and heavy equipment, the concrete floor of Building 6-605 started to breakdown. As a result, the product Stonclad was applied over the entire floor to protect the concrete floor from further erosive attacks (Western, 1977).

In addition to the process wastes, Building 6-605 generated sanitary effluent that discharged through drains to a septic tank and eventually to the process waste line at Sump \# 1. Based on process knowledge gained from previous septic system investigations on the NTS, the sanitary effluent may have hazardous and/or radioactive contamination present. In 1992, floating debris and oil were noted in the septic tank adjacent to Building 6-605 and is believed to be the result of overflow from clogged process waste lines (Radack, 1992).

Building 6-607 (Area 6 Decontamination Laundry) used soaps and detergents to clean the contaminated clothing used during testing and drilling activities. Effluent from Building 6-607 that was potentially contaminated with various inorganic, organic, and radiologically contaminated material, entered the septic system at Sump 3. In addition, Building 6-607 generated sanitary effluent that discharged through drains to a septic tank and eventually to the process waste at Sump \#3. Based on process knowledge gained from previous septic systems investigations on the NTS, the sanitary effluent may have hazardous and/or radioactive contaminants present.

Effluent from Building 6-606 likely contained solvents, degreasers, and lubricants that may have been used during equipment repair activities. Effluent discharged through drains and entered the process waste line south of Building 6-605. A concrete pad with a floor drain is located between Building 6-606 and 6-605. It is assumed this drain also contributes effluent to the process waste line but exact activities for this pad are unknown; however, at a minimum surface run-off would be generated. 
Documentation indicates several leaks from the subsurface piping at connection points of the old piping system to Building 6-605 and near Sump 2 may have occurred in the past. It is possible that other leaks occurred along the piping system, sumps, and/or septic tanks (Bingham, 1990 and1993; Bielawski, 1994).

The southeast area of the facility has been identified as a storage area for contaminated items and materials. Engineering drawings identify this area as the "Hot Side" and the "Hot Park Area." The specific details of activities in this area are undocumented. Contaminated equipment and materials staged in this area were exposed to the elements; therefore, release of oil from the equipment and deposition of contamination to the underlying soils was possible. The area is currently posted as a "Contamination Area."

The Closure Report for Petroleum Hydrocarbon Release at the Area 6 Decontamination Facility at the Nevada Test Site: Tank 6-605-1 (NDEM \#990204-3304) (DOE/NV, 2000a) identifies a release of petroleum hydrocarbons from UST 6-605-1. The tank was used to store heating oil for Building 6-605. When activities were stopped in the building the boiler was no longer needed and the UST was removed. The tank was located adjacent to the northwest corner of Building 6-605 and was closed by removing the tank and associated piping. Soil samples collected at the time of the closure indicated the presence of petroleum hydrocarbons in concentrations that exceed the state action level. Some soil was removed, but it is believed that the concentrations exceeding regulatory criteria remain under the building and/or near the electrical substation. The NDEP approved the site for closure in place with use restriction (DOE/NV, 2000a).

Previous Investigation Results - Sampling results from the Area 6 Decontamination Pond, the septic tanks that serviced Buildings 6-605 and 6-607, Sumps 1 and 2, and soil from around the process waste lines indicated the presence of numerous potential contaminants. Results indicate the presence of various solvents, acids, caustics, degreasers, detergents, alcohols, metals, radionuclides, petroleum hydrocarbons, VOCs, and SVOCs (DOE/NV, 1999).

Sampling results from closure of tank 6-605-1 indicate that petroleum hydrocarbons were present in concentrations as high as $13,000 \mathrm{mg} / \mathrm{kg}$ and that contaminants had migrated in the soil underneath Building 6-605 (DOE/NV, 2000a). 
Contaminants of Potential Concern - Chemical and radiological contaminants have been identified for this CAS based on previous investigation results and historical documentation. Various solvents, acids, caustics, degreasers, detergents, alcohols, and metals are parameters identified as COPCs. Based on investigations of similar facilities at the NTS and historical documentation, petroleum hydrocarbons are also COPCs. Beryllium and PCBs are a concern at the NTS and have not been ruled out by process knowledge.

Radionuclides that are associated with the fall-out from the nuclear weapons testing included americium (Am)-241, Barium-127m, cobalt (Co)-60, cesium (Cs)-137, europium (Eu)-152, Eu-154, plutonium (Pu)-238, Pu-239/240, Pu-241, samarium-151, strontium (Sr)-90, yttrium-90, tungsten (W)-181, W-187, and tritium (Adams, 2002; EG\&G/EM, 1986).

The following COPCs are identified for CAS 06-07-01:

- VOCs including methylene chloride, chlorobenzene, acetone, ethanol, xylene, xylene isomers, ethanol, isopropyl alchohol, ethylbenzene, toluene, 1,1,1-trichloroethane, 2-methylnapthalene, 2-(2-ethoxyethoxy)ethanol, and 2-butoxyethanol

- SVOCs including Bis(2-ethylhexyl)phthalate, butylbenzyphthalate, dioctyl ester (a.ka., di-N-octylphthalate), naphthalene, pentachlorophenol, bis(2-ethylhexy)ester, di-n-butylphthalate, and n-nitrosedipheynlamine

- Petroleum hydrocarbons including oil and grease, and petroleum naphtha

- Metals including nickel, antimony, copper, zinc, arsenic, barium, cadmium, chromium, lead, beryllium, silver, thallium, selenium, mercury, and lithium

- PCBs

- Caustics and acids

- Radionuclides to include Am-241, Co-60, Cs-137, Pu-238, Pu-239/240, Sr-90, U-234, U-235, $\mathrm{U}-238$, tritium (for liquids) and gamma-emitting radionuclides

\section{A.1.1.2 U.S. Environmental Protection Agency Farm}

On July 1, 1963, the AEC awarded a contract to the USPHS to study the transport of radioiodine from the environment to man, as well as the uptake by plants of long-lived fission products (SWRHL, 1967). The USPHS Farm was constructed in Area 15 of the NTS as a fully functioning 
diary to support these studies (EPA, 1973; SWRHL, 1967). The location of the farm was chosen based on the UE-15d Well, the location of roads and powerlines, and the fall-out in the area from the Plowshare Program. The radioiodine studies ended in 1970, at which time the USPHS was renamed the EPA (EPA, 1980). Various names have been used interchangeably for both the farm and the main building. The farm has been referred to as the EPA Farm, the USPHS Farm, and the PHS Farm. The main building has been referred to as Building 15-06, the Laboratory Building, the EPA Dairy Barn, and the Experimental Dairy Barn (DRI, 1994). The farm continued to be used until 1981 for other studies including metabolism studies on animals. By 1979, the farm no longer functioned as a full-time dairy and only brought in animals for specific experiments. On December 31, 1981, the DOE decided to decontaminate and decommission the farm. On October 23, 1997, closure activities at the farm were completed (DOE/NV, 1998a). Figure A.1-3 shows the general layout of the Area 15 EPA Farm and its associated CASs.

The majority of experiments occurred inside Laboratory Building 15-06 or nearby in the adjacent property. Corrective action sites 15-01-03, 15-04-01, 15-05-01, 15-08-01, and 15-23-03 received effluents from Laboratory Building 15-06 (Holmes \& Narver, 1971, 1974, 1975, and 1979). The sixth CAS (15-23-01) is associated with decontamination activities that took place in a separate location of the EPA Farm (Hopper, 1995). The rooms within the laboratory building included the hot slaughter room, milk room, milking area, sample control room, metabolism room, small animal laboratory, biology laboratory, autopsy laboratory, holding pen, utility room, rest room, and a change room for the workers (Edward B. Hendricks, 1965a, b, and c). Wastes from the metabolism and slaughter rooms were originally disposed via a waste line into a sump (CAS 15-23-03). In approximately 1974, an AST was installed (CAS 15-01-03) east of the sump to accept higher level radiological wastes (EPA, 1977). The wastes originating from both rooms were diverted at a distribution box between the AST and the sump, with the radiological wastes going to the AST and the nonradioactive or low-level wastes going to the sump (DOE, 1988; Olsen, 1997). The wastes from holding pens were also believed to have been disposed into the AST via the same waste line (Holmes \& Narver, 1971c).

Another waste stream from Building 15-06 consists of wastes from the small animal laboratory, biology laboratory, utility room, and rest room. Those wastes were disposed into the septic tank 


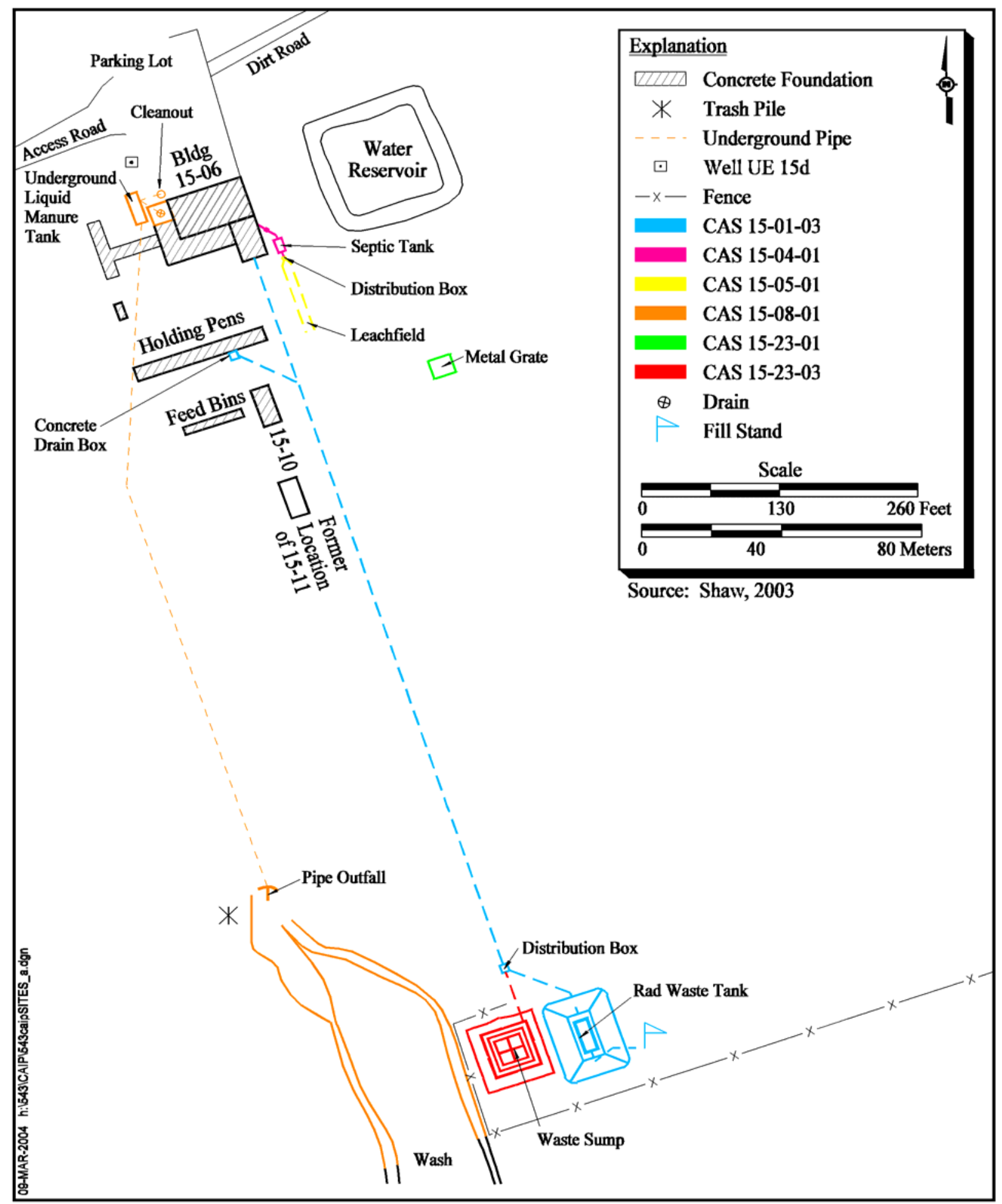

Figure A.1-3

EPA Farm Site MAP 
(CAS 15-04-01) and finally to the leachfield (CAS 15-05-01)(Holmes \& Narver, 1973a and b).

During the planning stages of the farm, there was a concern regarding the disposal of excess milk from the dairy herd and the adverse effects it might have on the biochemical activity in the septic tank. In addressing the concern, a commercially available liquid manure system was installed for the dairy operations. The liquid manure tank was installed in 1965, at the same time the Laboratory Building was constructed (SWRHL, 1967). The liquid manure tank was used for the accumulation of liquid waste and excess milk from the dairy cows. Wastes from the metabolism area, milking parlor, milk room, and holding pen were disposed of to the tank. After 1972, the liquid manure tank only received effluent from the milking area and milk room (EPA, 1977).

General sources of potential contamination common to all CASs within the Area 15 EPA Farm include the pesticides and fertilizers used and stored at the farm (SWRHL, 1967 and Boehlecke, 1997). Fertilizers sprayed on the crops fed to the animals used in the animal experiments consisted of ammonium nitrate, treble superphosphate and urea (SWRHL, 1967) in addition to the nitrogen and phosphorus fertilizers (SWRHL, 1967 and Boehlecke, 1997). As part of the animal studies, cobalt, manganese, and molybdenum were used in the animal feed (EPA, 1973).

There is a potential that waste water discharges from Well UE-15d may have been disposed down drains at the EPA Farm, resulting in the following contaminants being introduced into the EPA Farm waste stream: iron, manganese, lead, and mercury. These four contaminants exceeded the SDWA contaminant levels in 1984 (DOE, 1988).

Radionuclides associated with the fall-out from nuclear weapons testing Plowshare Project may be present in the surface soils of Area 15 and include typical fission products such as Cs-137, Am-241, Sr-90, and Pu isotopes (Adams, 2002; EG\&G/EM, 1986). Radionuclides used for the metabolism study at the EPA Farm include cerium-141, Sr-85, Mn-54, Scandium-46, Pu-238, iodine isotopes (121, 123, and 131), and iron-59 (EPA, 1973 and 1977).

Because the types of activities and disposal practices conducted at the Farm were similar and have the opportunity to affect all the CASs and components in a similar manner, five of the CASs have the same COPC list. For this reason, individual CAS descriptions of COPCs are not included in the 
following subsections but are listed in Table A.1-1. The exception is CAS 15-23-01, Underground Radioactive Material Area, because the nature of activities and release of contaminants is different than the rest of the Farm.

\section{A.1.1.3 CAS 15-04-01, Septic Tank}

Physical Setting and Operational History - This CAS is located adjacent and east of Building 15-06. The CAS consists of a 1,000-gal septic tank, cleanout, and associated piping. The piping consists of 4-in. cast-iron pipe from the building to the cleanout, where the pipe changes to 4-in. VCP from the cleanout to the septic tank (Edward B. Hendricks, 1965a; BN, Date Unknown b). Recent geophysical surveys and field observations were not able to confirm if the septic tank is still present at the site (SAIC, 2003).

The septic tank, piping, and cleanout were constructed in 1965 to service Laboratory Building 15-06 (Frazier, 1987). Originally, four floor drains, four sinks, and one toilet discharged to the septic tank. These drains, sinks, and toilet were located in the small animal laboratory, the biology laboratory, the utility room, and the rest room within Building 15-06 (Bingham, 1992; Olsen, 1997; Edward B. Hendricks, 1965b). In 1972, the waste water collection system was reconfigured to allow for separation of sanitary and nonsanitary wastes. With the exception of the floor drain in the utility room, all floor drains in the shower, and the toilet and sink in the toilet room, were connected to the manure tank. In 1973, two slaughter areas were added to the building. The drains in the slaughter areas were connected to the manure tank (Holmes \& Narver, 1973a and b).

Sources of Potential Contamination - The sources of potential contamination for the septic tank are considered the liquid wastes and effluent discharged through the floor drains and sinks within the Laboratory Building 15-06. The discharged effluent is associated with the sanitary sewage wastes and radioactive wastes from the laboratory testing and slaughter of animals within the laboratory.

Previous Investigation Results - This septic tank was sampled as part of the Preliminary Characterization of Abandoned Septic Tank Systems (DOE/NV, 1995) phase I activities. In this study, this septic system is identified as A15EPA. When sampled on September 12, 1994, the tank contained approximately 800 gal of waste, including an estimated $2-\mathrm{ft}$ layer of sludge. The liquid was relatively clear with floating particles and the sludge was dark brown to black and viscous. One 
liquid sample (A15EPA-T-L) and one sludge sample (A15EPA-T-S) were collected. The analytical results for these samples led to a recommendation that the septic system be closed as a "hydrocarbon containing tank" (DOE/NV, 1995).

A geophysical survey was conducted at CAS 15-04-01 in March 2003 over an area where the septic tanks were shown to be located on engineering drawings (SAIC, 2003). According to the survey, only anomalies consistent with underground piping were identified. No septic tank was located during the survey. It is possible that the tank may have been removed, or the area containing the tank may have fallen outside the boundaries of the survey. No documentation was located that confirms the removal of the septic tank.

\section{A.1.1.4 CAS 15-05-01, Leachfield}

Physical Setting and Operational History - This CAS is located adjacent and east of Building 15-06. The CAS consists of the distribution box, associated piping, and leachfield associated with the 1,000-gal septic tank (CAS 15-04-01) that serviced Building 15-06 (Edward B. Hendricks, 1965a; Holmes \& Narver, 1973a).

The leachfield consists of two subsurface 70 - $\mathrm{ft}$ long leach lines that are $8 \mathrm{ft}$ apart extending south from the distribution box. The leach lines consist of perforated 4-in. VCP. The dimensions for the distribution box are unknown (Edward B. Hendricks, 1965a; BN, Date Unknown c).

Sources of Potential Contamination - The sources of potential contamination for the distribution box and leachfield are the same as the septic tank (15-04-01) and are considered the liquid wastes and effluent collected through the floor drains and sinks within the Laboratory Building 15-06 and discharged to the septic tank.

Previous Investigation Results - The leachfield was sampled as part of the Preliminary Characterization of Abandoned Septic Tank Systems phase I activities (DOE/NV, 1995). In this study, this septic system is identified as A15EPA. On March 27,1995, one soil sample was collected below the first identified leachfield tile perforation. Barium, cadmium, and chromium, as well as oil and grease, were detected in the leachfield soil sample. Barium $(110 \mathrm{mg} / \mathrm{kg})$, was the only metal detected in the TCLP metal analysis at a concentration of $0.22 \mathrm{mg} / \mathrm{L}$. This result correlates with 
background concentrations for the area and was below the TCLP action level $(100 \mathrm{mg} / \mathrm{L})$ and the NDEP guidance level $(10 \mathrm{mg} / \mathrm{L})$. Cadmium was detected at $0.69 \mathrm{mg} / \mathrm{kg}$ and chromium was detected at $4.8 \mathrm{mg} / \mathrm{kg}$. Oil and grease was detected at $0.2 \mathrm{mg} / \mathrm{kg}$ and did not exceed the allowable liquid discharge limits for the Area 23 Sewage Lagoon. Although the sewage lagoon limits refers to liquids only, it is used here to provide an indication of the oil and grease characteristic of the leachfield soils. Tetrachloroethylene was detected at a concentration of $0.00033 \mathrm{mg} / \mathrm{L}$, and was also detected in the reagent blank $(0.00059 \mathrm{mg} / \mathrm{L})$ which suggests analytical interference. This concentration is below the TCLP action level of $0.07 \mathrm{mg} / \mathrm{L}$ and the NDEP guidance level of $0.07 \mathrm{mg} / \mathrm{L}$. In the background soil sample, TCLP barium was detected at $0.19 \mathrm{mg} / \mathrm{kg}$, which is below the TCLP action level $(100 \mathrm{mg} / \mathrm{L})$ and the NDEP guidance level of $10 \mathrm{mg} / \mathrm{L}$. The $\mathrm{pH}$ of the sample was 7.52 units and is not hazardous under 40 CFR 261.22 for corrosivity. Semivolatile organic compounds, TPH, and PCBs were not detected above laboratory reporting limits in the leachfield soil sample.

A geophysical survey, including CAS 15-05-01, was conducted on the NTS in March 2003 (SAIC, 2003). The survey was conducted to determine the location and dimensions of the leachfield. Various anomalies consistent with underground piping were identified that may potentially be the piping associated with the leachfield.

\section{A.1.1.5 CAS 15-08-01, Liquid Manure Tank}

Physical Setting and Operational History - This CAS is located adjacent to the northwest corner of the Building 15-06 foundation and consists of a liquid manure tank and its associated piping. The liquid manure tank consisted of an 18,000-gal underground concrete tank that measures $32 \times 12 \times 8 \mathrm{ft}$ and the top of the tank is even with the ground surface (SWRHL, 1967; BN, Date Unknown b; Edward B. Hendricks, 1965b). Included in the CAS is piping between the tank and the building and the outside floor drain in the center of a concrete pad. Also included in this CAS is outflow piping that extends south from the tank approximately $550 \mathrm{ft}$ to a drainage wash. The 6-in. diameter outflow pipe, south of Building 15-06, surfaces from the ground at the head of the wash. The wash is approximately 4 to $5 \mathrm{ft}$ wide and 2 to $3 \mathrm{ft}$ deep.

The manure tank had a clock-operated agitator to keep the solids in suspension. A special chopper pump emptied the tank into a tank wagon, which was used to spread the contents over the crop fields. An interviewee stated the liquid wastes in the tank were pumped into an outflow pipe and allowed to 
flow south, eventually discharging into the small wash (Hopper, 2003). An outflow pipe was identified during a field visit that was located south of Building 15-06. Further, a geophysical survey conducted in March 2003 identified a line that connects the manure tank to the outflow pipe (SAIC, 2003). It is believed that this outflow line was at some time used to discharge wastes from the liquid manure tank; however, there has been no documentation found that details these activities.

Sources of Potential Contamination - The sources of potential contamination are the activities that were conducted in Building 15-06 and the manure waste and milk from the diary operations.

Originally the liquid manure tank collected wastewater from a drinking fountain drain, a service sink drain, as well as floor drains in the milking parlor, milk room, metabolism area, and the 20- x 20-ft concrete pad off the northwest side of the building (BN, Date Unknown b). The tank was used to collect excess milk and wash down effluent from the dairy operation. In 1972 the building was reconfigured. The metabolism area was moved to the east side of the building and a new drain system was added. After this, waste from the metabolism area was no longer collected in the liquid manure tank (EPA, 1977).

Previous Investigation Results - A geophysical survey was conducted at CAS 15-08-01 during March 2003 (SAIC, 2003). The results identified the underground line associated with the outflow at the southern end of the farm. The line ran north approximately $550 \mathrm{ft}$ to the liquid manure tank (EPA, 1977).

Radiological surveys performed in August 1997 in support of the CAU 95 CADD did not identify any removable-surface or fixed-surface contamination in the areas of Building 15-06 that are associated with the liquid manure tank. Radiological walk-over surveys performed at the NTS during February 18 and 19, 2003, included CAS 15-08-01. No risk to individuals from residual radiological contamination was identified (Nicosia, 2003).

\section{A.1.1.6 CAS 15-23-03, Contaminated Sump, Piping}

Physical Setting and Operational History - Corrective Action Site 15-23-03 is located approximately $875 \mathrm{ft}$ south of the Building 15-06 foundation at the EPA Farm. This CAS consists of a $25 \times 25 \times 6 \mathrm{ft}$ deep sump and subsurface piping extending approximately $60 \mathrm{ft}$ north to a distribution box. The dimensions of the distribution box are approximately $31 \times 36$ in. The sides of the sump are 
constructed of concrete angled at 45 degrees and the bottom is unlined. Currently, there are metal stakes and chicken wire covering the entire sump area.

The contaminated waste sump was not part of the original farm construction plans and was added in 1972 when the large animal metabolism facility was converted from the telemetry, data analysis, and biology rooms (DRI, 1988; Hopper, 2003). The sump was used for the accumulation of liquid waste from the laboratory (Holmes \& Narver, 1972a and b). Documentation indicates the sump was not used for radioactive waste; however, the sump area is posted with "Underground Radioactive Material" signs (Shaw, 2003; DOE/NV, 2000). In 1974, an AST (CAS 15-01-03) was added adjacent to the sump to receive radiologically contaminated waste. The distribution box, located about $60 \mathrm{ft}$ north of the sump, was added to divert the radioactive waste to the tank and nonradioactive waste to the sump.

Sources of Potential Contamination - The sump and associated piping included in CAS 15-23-03 supported the activities in Building 15-06. Engineering drawings indicate floor drains in the metabolism area, the Sample Control Room, and the Shower Room, and the slaughter areas (added in 1973), as well as service sinks in these areas were connected to the piping that terminated at the sump (Holmes \& Narver, 1972a, b, and 1974). The distribution box and tank for collection of highly contaminated liquid waste was not added until 1974 (Olsen, 1997; DOE, 1988). It is not stated what criteria determined when the waste was diverted to the tank from the sump. There is no mention of flushing the line prior to waste being diverted to the sump. There is the potential for all waste entering the drainline from Building 15-06 to contribute to contamination at this CAS.

Previous Investigation Results - A demarcation survey of the EPA Farm area was conducted on August 6, 1998 (DOE/NV, 2000b). The figure that accompanies the report indicates the EPA Farm Pond Underground Radioactive Material Area Boundary and the EPA Farm Storage Tank Contamination Area Boundary as one boundary. This boundary encompasses both the sump and the AST. The radionuclides in the soil are expected to be americium and plutonium. The DOE/NV (2000b) report states that the subsurface soils contained unknown levels of radionuclide activity, but the surface-soil removable activity was well below 10 CFR 835 guidelines. 


\section{A.1.1.7 CAS 15-01-03, Aboveground Storage Tank}

Physical Setting and Operational History - This CAS is located approximately $875 \mathrm{ft}$ south of Building 15-06. This CAS includes the 25,000-gal AST, its contents, and the fill stand located within the bermed area; approximately $875 \mathrm{ft}$ of associated piping originating from Building 15-06 and the holding pens; the distribution box ( $31 \times 36$ in.) located approximately $60 \mathrm{ft}$ from the AST; the concrete drain box located at the holding pens, and the surrounding soil. The cylindrical AST is located within a pit and is approximately $31 \mathrm{ft}$ long and $21 \mathrm{ft}$ in diameter, with an estimated capacity of 25,000 gal. A gauge on top of the AST reads approximately 24,000 gal (Shaw, 2003). If the gauge reads correctly, the tank is full. The exact contents of the AST are uncertain. A pump motor is noted on a drawing at the southern end of the AST (REECo, 1975). The piping also branches northwest from the main line to a concrete drain box located at the holding pens (REECo, 1975).

During a site visit on February 11, 2003, staining was observed on the sides of the tank near the southernmost access ports (Shaw, 2003). Tumble weeds in the pit hinder viewing the bottom of the pit for any possible staining. It is believed that the AST may have released contaminants to the surface soil at some time during the operation of the facility. The piping on the southern end of the tank, near the fill stand, is covered with what may be ACM.

Sources of Potential Contamination - The AST was used to support the disposal of contaminated wastes from the EPA Farm Building 15-06. The wastes in the tank originated from the metabolism and slaughter rooms within Building 15-06 (Holmes \& Narver, 1971c).

The wastes within the tank were periodically transferred into a tanker and disposed in the U8d dump hole (CAU 542) (ERDA, 1976; DRI, 1988). The tank may have been emptied about four or five times during the life of the farm studies. Engineering drawings indicate that the tank was equipped with a pump and motor to aid the transfer of waste from the tank to the tanker (REECo, 1975).

Previous Investigation Results, Experimental Studies, Historical Documentation - No specific investigation results were identified. 


\section{A.1.1.8 CAS 15-23-01, Underground Radioactive Material Area}

Physical Setting and Operational History - This CAS is located southeast of Building 15-06 and approximately $150 \mathrm{ft}$ south of the septic tank. The CAS consists of PSP measuring approximately 22 by $22 \mathrm{ft}$ and the surrounding and underlying soil. Corrective Action Site 15-23-01 was originally identified as a contaminated dry waste well located beneath the grain silo next to Trailer 15-12. Based on the results of interviews, a review of historical documentation, and a geophysical survey, it is believed that the well does not, nor did it ever, exist at the site (Barth, 2003; Giles, 2003). The term "well" may have been used at one time to describe a pit or a sump filled with coarse gravel.

According to interviewees, this CAS was used as a decontamination area for various pieces of farm equipment (Hopper, 1995 and 2003). Activities at the farm included the spraying of iodine-131 and tritiated water on the crop fields that were located on the east side of the farm (Hopper, 1995; Sorom, 1995). Wastes from the liquid manure tank (CAS 15-08-01) were also reported to have been spread on the fields. Pesticides and herbicides were also applied to the fields to manage the weeds and pests. The workers, and potentially the equipment used in the crop fields, would proceed to the metal grate for decontamination after leaving the fields. Decontamination was conducted at this location in order to prevent the spread of contamination from the "hot" east side of the farm, to the "cold" west side of the farm. The RSO would conduct the decontamination process, using equipment and supplies stored in the adjacent RadSafe Trailer 15-12 (Hopper, 1995 and 2003).

Sources of Potential Contamination - Decontamination activities at this site were in support of the work performed during the management of the crops planted at the farm. This may have included decontamination of personnel, tools, and equipment. These activities are considered the source of any contamination that exists in the surface and shallow subsurface soil within the CAS boundary.

Previous Investigation Results - A Site Monitoring/Site Demarcation Survey of Area 15 Site Dry Well was performed in May 1991 (Smith, 1991). The sketch on the checklist indicates an area that is consistent with the description of this CAS. The survey was conducted at four locations at the dry well, 270 degrees west, 180 degrees south, 90 degrees east, and 360 degrees north. The results for beta/gamma were $100 \mathrm{cpm}, 100 \mathrm{cpm}, 120 \mathrm{cpm}$, and $100 \mathrm{cpm}$, respectively. For alpha, the results were $0 \mathrm{cpm}$ at all locations. 
Radiological walk-over surveys performed at the NTS during February 18 and 19, 2003, included CAS 15-23-01. No radiological contamination was identified (Nicosia, 2003).

Geophysical surveys were conducted at various sites at the NTS in March 2003 (SAIC, 2003). Corrective Action Site 15-23-01 was included in the sites surveyed. Four anomalies were identified in the area. Anomaly "D" corresponds with the area for CAS 15-23-01. The anomaly coincided with the PSP that is located at the surface of the site.

Potential Contamination - Gamma-emitting radionuclides and general radionuclides associated with nuclear weapons testing fallout are COPCs. The COPCs that are common to decontamination activities include degreasers, solvents, detergents, and TPH. Based on process knowledge of typical NTS practices and EPA farm practices, additional COPCs include metals with beryllium, herbicides, pesticides, and PCBs.

\section{A.1.2 Seven-Step DQO Process}

This following section presents the seven-step DQO process employed for the development of the sampling and analysis plan for CAU 543.

\section{A.1.2.1 Step 1 - State the Problem}

This initial step of the DQO process identifies the planning team members and decision makers, describes the problem that has initiated the CAU 543 CAI, and develops the CSMs.

\section{A.1.2.2 Planning Team Members}

The DQO planning team consists of representatives from NDEP, NNSA/NSO, SNJV, and BN. The primary decision makers include NDEP and NNSA/NSO representatives. Table A.1-2 lists representatives from each organization in attendance at the February 26, 2004, DQO planning meeting.

\section{A.1.2.3 Describe the Problem}

Corrective Action Unit 543 is being investigated because the activities conducted at the Area 6 Decontamination Facility (CAS 06-07-01) and EPA Farm (CASs 15-01-03, 15-04-01, 15-05-01, 15-08-01, 15-23-01, and 15-23-03) may have released hazardous and/or radiological contaminants 
Table A.1-2

DQO Meeting Participants

\begin{tabular}{||l|l|l||}
\hline \multicolumn{1}{|c|}{ Participant } & \multicolumn{1}{|c|}{ Affiliation } & \multicolumn{1}{c|}{ Function } \\
\hline \hline Dawn Arnold & SNJV & Industrial Sites CAU Lead \\
\hline Stacey Alderson & SNJV & Radiation Services Manager \\
\hline Sabine Curtis & NNSA/NSO & Environmental Restoration Division Task Manager \\
\hline Syl Hersh & SNJV & Quality Processes Technical Staff \\
\hline Brian Hoenes & SNJV & Industrial Sites Project Manager \\
\hline Dave Madsen & BN & Environmental Restoration Task Lead \\
\hline Harry A. Perry & BN & Waste Management Lead \\
\hline Al Wickline & SNJV & Industrial Sites Task Manager \\
\hline Jeanne Wightman & SNJV & Quality Processes Representative \\
\hline Ted Zaferatos & NDEP & Oversight/Representative \\
\hline
\end{tabular}

BN - Bechtel Nevada

NDEP - Nevada Division of Environmental Protection

NNSA/NSO - U.S. Department of Energy, National Nuclear Security Administration Nevada Site Office

SNJV - Stoller-Navarro Joint Venture

into the environment at concentrations that could potentially pose a threat to human health and/or the environment during future use.

The problem statement for CAU 543 is that the existing information on the nature and extent of potential contamination is insufficient to evaluate and recommend corrective action alternatives for the CASs comprising CAU 543.

\section{A.1.2.4 Develop Conceptual Site Models}

Conceptual site models describe the most probable scenarios for current conditions at specific sites and define the assumptions that are the basis for identifying appropriate sampling strategy and data collection methods. They set the stage for assessing how contaminants could reach receptors both in the present and future by addressing contaminant release and migration pathways, transport mechanisms, potential receptors, and potential exposures to those receptors. Accurate CSMs are important as they serve as the basis for all subsequent inputs and decisions throughout the DQO process. Land-use descriptions help define exposure scenarios, which are the basis for assessing how contaminants could reach potential receptors both in the present and future. There are two future 
land-use scenarios for CAU 543. Corrective Action Site 06-07-01 is within the Defense Industrial Zone. The remaining CASs are within the Reserved Zone on the NTS (DOE/NV, 1998b). Based on land use, current and future receptors are limited to industrial and construction workers as well as personnel conducting training maneuvers. These human receptors may be exposed to COPCs through oral ingestion, inhalation, dermal contact (absorption) of soils and/or debris (e.g., equipment, concrete) due to inadvertent disturbance of these materials or irradiation by radioactive material(s).

Two CSMs have been developed for CAU 543 using assumptions formulated from the physical setting, historical background, and potential contaminant sources and release information at Area 6 and Area 15. The components in the Area 6 CAS (06-07-01) and the CASs in the Area 15 EPA Farm are integrated or interrelated as part of a larger system or process with shared sources of potential contamination for each respective area; therefore, a separate CSM has been developed for Area 6 and Area 15. To better illustrate the more complex, integrated process of the Area 15 EPA Farm, Figure A.1-4 has been developed as a Flow Diagram. The Flow Diagram walks through the common sources of contamination and related release points and pathways which help to establish the CSM. The CSMs for CAU 543 are termed:

- $\quad$ Conceptual Site Model for Area 6, Decontamination Processes

- Conceptual Site Model for Area 15, EPA Farm Processes

The following subsections discuss each CSM.

\section{A.1.2.5 Conceptual Site Model for Area 6, Decontamination Processes}

Conceptual Site Model for Area 6 applies to the components of CAS 06-07-01 that were designed to collect and discharge decontamination effluent and sanitary waste streams including septic tanks, sumps, and underground piping. Upon release from the source, the effluent traveled through discharge lines and was routed into the various septic system components and sumps. The designed and accidental release points within the collection and distribution system create potential exposure pathways. Included in this CSM, although not part of the effluent collection system, is the contaminated soils within a designated "Contamination Area." These soils were contaminated from the same equipment and materials that were decontaminated at the Area 6 Decontamination Facility. Figure A.1-5 shows a generalized representation of the Area 6 CSM. 


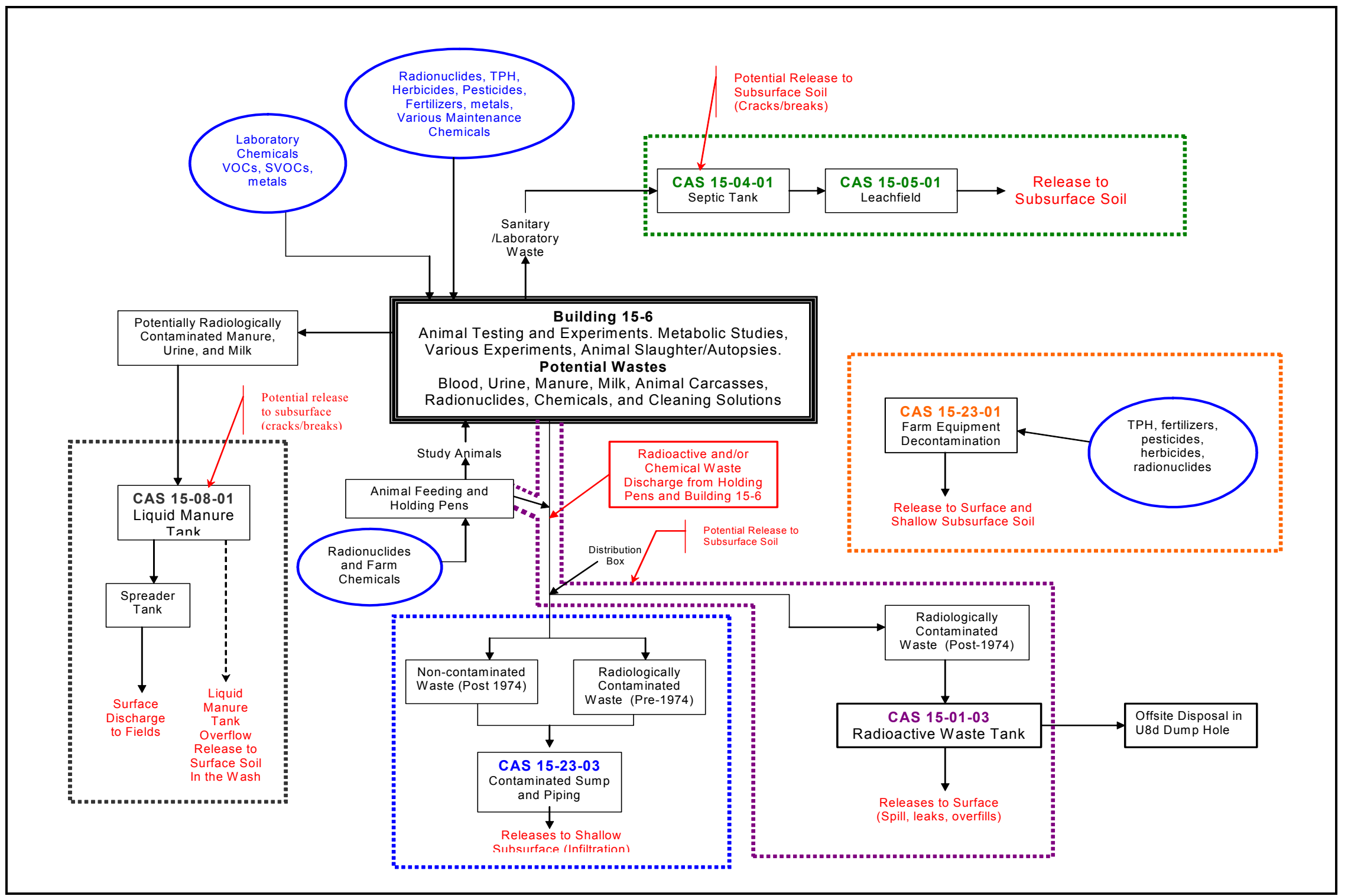

Figure A.1-4

Process Flow Diagram for the Area 15 EPA Farm 


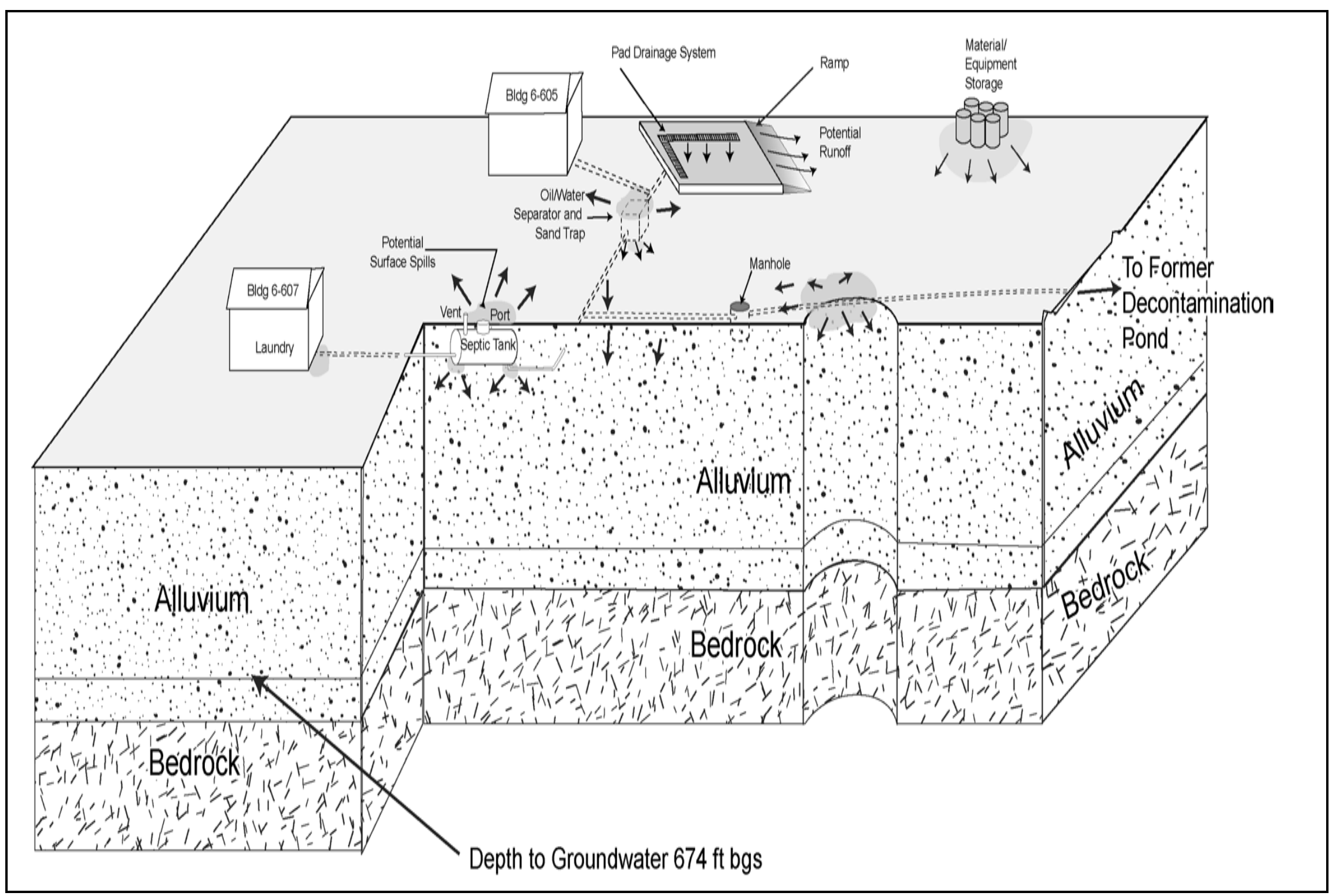

Figure A.1-5

Conceptual Site Model for Area 6 


\section{A.1.2.6 Conceptual Site Model for Area 15, EPA Farm Processes}

Conceptual Site Model for Area 15 applies to CASs and components of each CAS that were parts of an integrated system to collect and discharge waste streams from the activities associated with the EPA Farm animal testing and experiments. The primary source of contamination was generated within one building, the Laboratory Building 15-06; however, several other areas within the Farm also contributed wastes (i.e., holding pens). Upon release from the source, sanitary, hazardous, and radioactive effluent traveled through discharge lines and was routed to various distribution components that include a septic tank and leachfield, an underground storage tank, a sump, ASTs, and an outfall. There are designed and accidental release points in this model. Figure A.1-6 shows a generalized representation of the Area 15 CSM.

Affected Media - Soils beneath and surrounding the sumps, septic tanks, aboveground and underground tanks, and associated piping potentially could be affected by the release of contaminants either by design or accident (i.e, overflow). The components of the piping, tanks, concrete pads, drains, and building structures in direct contact with potential contaminants may be affected. Structures and equipment within Building 6-605 may be affected from direct contact with decontamination fluids (e.g., acids and caustics). Surface and shallow subsurface soils may be affected by contaminants from stored equipment and materials, surface run-off from exposed pads, and outfall effluent.

Location of Contamination/Release Points - Releases of contamination to the environment are most likely to have occurred beneath the outlet and inlet pipe ends and the base of the septic tanks, sumps, distribution box, tanks, along perforated piping (leachfield), or beneath any breaches in underground piping from cracks, breaks, or overflow of the components. Stored contaminated materials in the storage area may have spread contamination onto the surface soils via runoff or erosion. Surface run-off from any of the concrete pads may have contributed contamination to the surrounding soils.

Transport Mechanisms - An important element of a CSM is the expected fate and transport of contaminants, which infer how contaminants move through site media and where they can be expected in the environment (migration pathway). The expected fate and transport is based on distinguishing physical characteristics of the contaminants and media. Contaminant characteristics include solubility, density, and particle size. Media characteristics include permeability, saturation, 


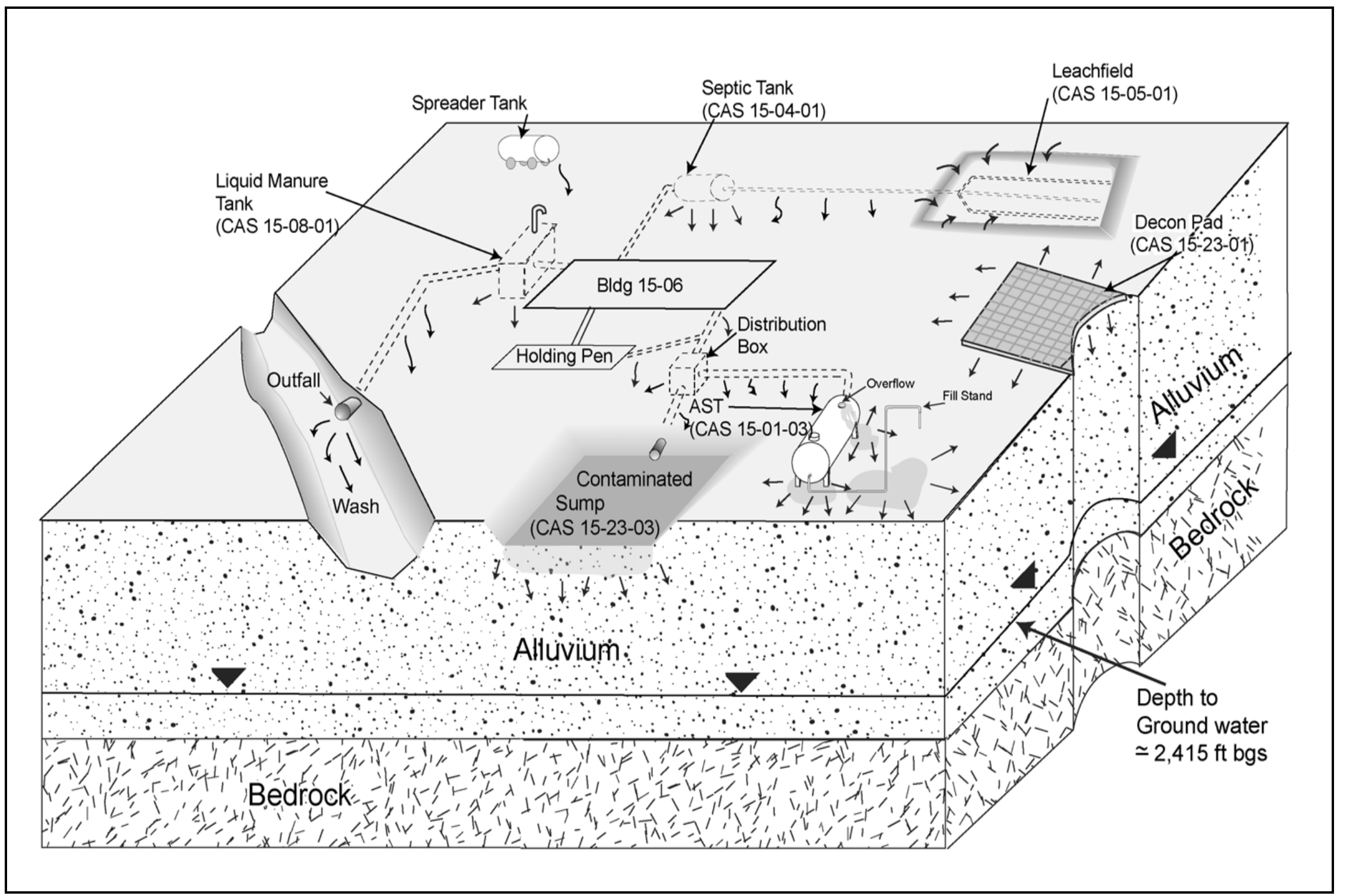

Figure A.1-6

Conceptual Site Model for Area 15, EPA Farm Processes 
sorting, chemical composition, and adsorption coefficients. In general, contaminants with low solubility and high density can be expected to be found relatively close to release points.

Contaminants with high solubility and low density can be expected to be found further from release points or in areas where settling may occur.

Migration of potential contamination is assumed to be minimal based on the affinity of the COPCs for soil particles, and the low precipitation and high evapotranspiration rates typical of the NTS environment. Contaminants may have been transported by infiltration and percolation of precipitation through soil, which would serve as the primary driving force for downward migration. Based on the release points within both Area 6 and Area 15, migration would be expected primarily downward with horizontal migration to a much lesser degree. Mixing of the surface soils as a result of grading or construction activities could also move COPCs into deeper intervals. The migration of organic constituents (e.g., pesticides and TPH) can be controlled to some extent by their affinity of organic material present in the soil. However, this mechanism is considered insignificant because of the lack of organic carbon in the desert soil. Migration of certain inorganic constituents (e.g., metals) is controlled by geochemical processes, such as adsorption, ion exchange, and precipitation of solids from solution.

Contaminants migrating to regional aquifers are not considered a likely scenario at CAU 543 based on the average depth to groundwater, the low annual average precipitation rates, the high potential for evapotranspiration, and the low mobility of expected COPCs (e.g., SVOCs, PCBs, petroleum hydrocarbons, and RCRA metals). The average depth to groundwater in Area 6 is 1,425 ft and $690 \mathrm{ft}$ at the EPA farm in Area 15 (DRI, 1993).

Airborne release subsequent to initial contamination release is not considered a significant release pathway. The main process of migration via the airborne pathway would be through windblown dust with COPCs adsorbed to the fine soil particles. This process could result in the deposition of COPCs beyond the CAS boundaries; however, it would be expected that contaminant levels decrease with distance from the point of release and distributed consistent with prevailing wind direction.

Preferential Pathways - Preferential pathways for contaminant migration at most of CAU 543 sites are expected to have only a minor impact on contaminant migration or none at all. 
Lateral and Vertical Extent of Contamination - The degree of contaminant migration, if any, at these sites is unknown, but it is assumed to be minimal and confined to the surface and shallow subsurface soils. Any contamination at these sites is expected to be contiguous with the source and decrease with distance and depth from the release point. It is believed that groundwater has not been, or would not be, impacted because of the significant depths of groundwater levels, and the high evapotranspiration rates. Because of the relatively flat terrain in these areas, horizontal migration beyond the area of initial impact is expected to be limited, and liquids would primarily infiltrate vertically into the soil at or near the point of release. Although infrequent, surface migration may have occurred as a result of storm events when precipitation rates exceeded infiltration rates (stormwater run-off). The primary lateral migration pathways would be dispersion through the shallow soil and limited migration in the down gradient direction.

\section{A.1.3 Step 2 - Identify the Decision}

The purpose of this section is to develop the decisions that require environmental data to address the presence of contamination and identify appropriate alternative actions for the investigation.

\section{A.1.3.1 Develop a Decision Statement}

Problem statement is: "There is an insufficient amount of information concerning the nature and extent of contamination released at these sites to determine if there is an unacceptable risk to human health and the environment."

The Decision I statement is: "Is a contaminant present within a CAS at a concentration that could pose an unacceptable risk to human health and the environment?"

Any contaminant detected at a concentration exceeding the corresponding PAL defined in Section A.1.4.2 will be considered a COC. A COC is defined as a site-related constituent that exceeds the PAL. The presence of a contaminant within a CAS is defined as the analytical detection of a COC. Samples used to resolve Decision 1 are identified as Decision I samples.

The Decision II statement is: "If a COC is present, is sufficient information available to determine the lateral and vertical extent of the contamination?" 
Sufficient information is defined as the data needs identified during the DQO process to include the lateral and vertical extent of all COCs within each CAS. Samples used to resolve Decision II are identified as Decision II samples.

\section{A.1.3.2 Alternative Actions to the Decision}

If a COC is not present, further assessment of the CAS is not required. If a COC is present, resolve Decision II.

If the extent of a COC is defined in both the lateral and vertical directions, further assessment of the CAS is not required. If the extent of a COC is not defined, re-evaluate site conditions and collect additional samples.

\section{A.1.4 Step 3 - Identify the Inputs to the Decision}

This step identifies the information needed, determines sources for information, determines the basis for establishing the action level, and identifies sampling and analysis methods that can meet the data requirements. To determine if a COC is present, each sample result or population parameter is compared to the PAL. If any sample result or population parameter is greater than the PAL, then the CAS is advanced to Decision II for that parameter. This approach does not use a statistical mean/average for comparison to the PAL, but rather a point-by-point comparison to the established screening criteria to identify COCs.

\section{A.1.4.1 Information Needs and Information Sources}

In order to determine if a COC is present at the CAS, sample data must be collected and analyzed following these two criteria: (1) samples must be collected in areas most likely to contain a COC and (2) the analytical suites and associated MDLs selected must be sufficient to detect any COCs present in the samples below their corresponding PALs. Biasing factors to support these criteria include:

- Documented process knowledge on source and location of release

- Field observations

- Field-screening results

- Historical sample results

- Interpretation of geophysical and/or radiological survey data

- Experience and data from investigations of similar sites

- Professional judgement 
In order to determine the extent of a COC for Decision II, sample data must be collected and analyzed at locations to bound the lateral and vertical extent of COCs. The data required to satisfy the information needed for Decision II for each COC is a sample result that is below the PAL. Step-out locations will be selected based on the CSM, biasing factors, and existing data. Analytical suites may only include those parameters that exceeded PALs (i.e., COCs) in Decision I samples. Biasing factors to support these information needs may include the factors previously listed and Decision I analytical results. Table A.1-3 lists the information needs, the source of information for each need, and the proposed methods to collect the data needed to resolve Decisions I and II. The last column addresses the QA/QC data type and associated metric. The data type is determined by the intended use of the resulting data in decision making.

Data types are discussed in the following text. All data to be collected are classified into one of three measurement quality categories: quantitative, semiquantitative, and qualitative. The categories for measurement quality are defined below.

\section{Quantitative Data}

Quantitative data results from direct measurement of a characteristic or component within the population of interest. These data require the highest level of QA/QC in collection and measurement systems because the intended use of the data is to resolve the primary decision (i.e., rejecting or accepting the null hypothesis) and/or verifying closure standards have been met. Laboratory analytical data are usually assigned as quantitative data.

\section{Semiquantitative Data}

Semiquantitative data is generated from a measurement system that indirectly measures the quantity or amount of a characteristic or component of interest. Inferences are drawn about the quantity or amount of a characteristic or component because a correlation has been shown to exist between results from the indirect measurement and the quantitative measurement. The QA/QC requirements on semiquantitative collection and measurement systems are high, but may not be as rigorous as a quantitative measurement system. Semiquantitative data contribute to decision making, but are not generally used alone to resolve primary decisions. The data are often used to guide investigations toward quantitative data collection and increase the efficiency of the sampling effort. 
Table A.1-3

Information Needs to Resolve the Decision I and Decision II Decisions

\begin{tabular}{|c|c|c|c|}
\hline $\begin{array}{l}\text { Information } \\
\text { Need }\end{array}$ & Information Source & Collection Method & Data Type/Metric \\
\hline \multicolumn{4}{|c|}{$\begin{array}{l}\text { Decision I: Determine if a COC is present. } \\
\text { Criteria I: Samples must be collected in areas most likely to contain a COC. }\end{array}$} \\
\hline \multirow[t]{6}{*}{$\begin{array}{l}\text { Source and location } \\
\text { of release points }\end{array}$} & $\begin{array}{l}\text { Process knowledge compiled } \\
\text { during the preliminary assessment } \\
\text { and previous investigations of } \\
\text { similar sites }\end{array}$ & $\begin{array}{l}\text { Information documented in CSM } \\
\text { and public reports - no } \\
\text { additional data needed }\end{array}$ & $\begin{array}{l}\text { Qualitative - CSM has not been } \\
\text { shown to be inaccurate }\end{array}$ \\
\hline & Site visit and field observations & $\begin{array}{l}\text { Conduct site visits and } \\
\text { document field observations }\end{array}$ & $\begin{array}{l}\text { Qualitative - CSM has not been } \\
\text { shown to be inaccurate }\end{array}$ \\
\hline & Aerial photographs & $\begin{array}{l}\text { Review and interpret aerial } \\
\text { photographs }\end{array}$ & $\begin{array}{l}\text { Semiquantitative - Sampling based } \\
\text { on biasing criteria stipulated in } \\
\text { DQO Step } 3\end{array}$ \\
\hline & Radiological surveys & $\begin{array}{l}\text { Review and interpret } \\
\text { radiological surveys }\end{array}$ & $\begin{array}{l}\text { Semiquantitative - Sampling based } \\
\text { on biasing criteria stipulated in } \\
\text { DQO Step } 3\end{array}$ \\
\hline & Geophysical surveys & Review and interpret surveys & $\begin{array}{l}\text { Semiquantitative - Sampling based } \\
\text { on biasing criteria stipulated in } \\
\text { DQO Step } 3\end{array}$ \\
\hline & Field screening & $\begin{array}{l}\text { Conduct field screening during } \\
\text { the initial sampling to determine } \\
\text { if contamination is present at } \\
\text { suspected locations }\end{array}$ & $\begin{array}{l}\text { Semiquantitative - Sampling based } \\
\text { on biasing criteria stipulated in } \\
\text { DQO Step } 3\end{array}$ \\
\hline \multicolumn{4}{|c|}{$\begin{array}{l}\text { Decision I: Determine if a COC is present. } \\
\text { Criteria 2: Analyses must be sufficient to detect any COCs in samples. }\end{array}$} \\
\hline $\begin{array}{l}\text { Identification of all } \\
\text { potential } \\
\text { contaminants }\end{array}$ & $\begin{array}{l}\text { Process knowledge compiled } \\
\text { during the preliminary assessment } \\
\text { and previous investigations of } \\
\text { similar sites }\end{array}$ & $\begin{array}{l}\text { Information reported in the CSM } \\
\text { and public reports - no } \\
\text { additional data needed }\end{array}$ & $\begin{array}{l}\text { Qualitative - CSM has not been } \\
\text { shown to be inaccurate }\end{array}$ \\
\hline Analytical results & Data packages of biased samples & $\begin{array}{l}\text { Appropriate sampling } \\
\text { techniques and approved } \\
\text { analytical methods will be used }\end{array}$ & $\begin{array}{l}\text { Quantitative - Detection limits will } \\
\text { be less than or equal to PALs }\end{array}$ \\
\hline \multicolumn{4}{|c|}{ Decision II: Determine the lateral and vertical extent of a COC. } \\
\hline $\begin{array}{l}\text { Identification of } \\
\text { applicable COCs }\end{array}$ & $\begin{array}{l}\text { Data packages of Decision I or } \\
\text { other prior samples }\end{array}$ & $\begin{array}{l}\text { Review Decision I analytical } \\
\text { results and compare to } \\
\text { respective PALs to identify } \\
\text { COCs }\end{array}$ & $\begin{array}{l}\text { Quantitative - Only COCs } \\
\text { identified will be analyzed in future } \\
\text { sampling events }\end{array}$ \\
\hline \multirow[t]{3}{*}{$\begin{array}{l}\text { Extent of } \\
\text { Contamination }\end{array}$} & Field observations & Document field observations & $\begin{array}{l}\text { Qualitative - CSM has not been } \\
\text { shown to be inaccurate }\end{array}$ \\
\hline & Field screening & $\begin{array}{l}\text { Conduct field screening with } \\
\text { appropriate instrumentation }\end{array}$ & $\begin{array}{l}\text { Semiquantitative - FSRs will be } \\
\text { compared to FSLs }\end{array}$ \\
\hline & Decision II analytical results & $\begin{array}{l}\text { Appropriate sampling } \\
\text { techniques and approved } \\
\text { analytical methods will be used } \\
\text { to bound COCs }\end{array}$ & $\begin{array}{l}\text { Quantitative - Validated analytical } \\
\text { results will be compared to PALs to } \\
\text { determine COC extent }\end{array}$ \\
\hline
\end{tabular}




\section{Qualitative Data}

Qualitative data identifies or describes the characteristics or components of the population of interest. The QA/QC requirements for qualitative data are the least rigorous on data collection methods and measurement systems. Professional judgement is often used to generate qualitative data. The intended use of the data is for information purposes, to refine conceptual models, and to guide investigations rather than resolve primary decisions. This measurement of quality is typically associated with historical information and data where QA/QC may be highly variable or not known. Metrics provide a tool to determine if the collected data support decision making as intended. Metrics tend to be numerical for quantitative and semiquantitative data, and descriptive for qualitative data.

\section{A.1.4.2 Determine the Basis for the Preliminary Action Levels}

Industrial site workers, construction/remediation workers, and training (i.e., military) personnel may be exposed to contaminants through oral ingestion, inhalation, external (radiological), or dermal contact (absorption) of soil. Laboratory analytical results for soils will be compared to the following PALs to evaluate if COPCs are present:

- EPA Region IX Risk-Based Preliminary Remediation Goals for Industrial Soils (EPA, 2002b).

- For detected chemical COPCs without established PRGs that are listed in the EPA IRIS database (EPA, 2002c), the protocol used by the EPA Region 9 in establishing PRGs (or similar) will be used in establishing the PALs.

- Background concentrations for metals are considered when natural background exceeds the PRG, as is often the case with arsenic. Background is considered the mean plus two times the standard deviation of the mean for sediment samples collected by the Nevada Bureau of Mines and Geology throughout the Nevada Test and Training Range (formerly the Nellis Air Force Range) (NBMG, 1998; Moore, 1999).

- TPH action level of $100 \mathrm{mg} / \mathrm{kg}$ per the NAC 445A.2272 (NAC, 2002).

- The PALs for radionuclides, except those covered by DOE Order 5400.5 (DOE, 1993), were taken from the construction, commercial, industrial land-use scenario in Table 2.1 of the NCRP Report No. 129, Recommended Screening Limits for Contaminated Surface Soil and Review Factors Relevant to Site-Specific Studies (NCRP, 1999). The values provided in this source document are based on a $25 \mathrm{mrem} / \mathrm{yr}$ dose but have been scaled to a $15 \mathrm{mrem} / \mathrm{yr}$ dose for the purpose of this investigation.

- The PALs for Ra-226, Ra-228, Th-230, and Th-232 and their progeny in secular equilibrium 
are the generic guidelines for residual counteractions as found in Chapter IV of DOE Order 5400.5 Change 2, Radiation Protection of the Public and Environment (DOE, 1993).

- For radiologically contaminated materials and structures, the total residual surface contamination for unrestricted release of materials and equipment to the general public allowed by DOE Order 5400.5 (DOE, 1993) and as defined in the NV/YMP RadCon Manual (DOE/NV, 2000c).

The selected PALs are based on the EPA Region 9 Industrial Land Use PRGs. The PRGs are risk-based tools for evaluating and cleaning up contaminated sites that estimate contaminant concentrations in environmental media (i.e., soil, air, and water) that EPA considers protective of humans (including sensitive groups) over a lifetime. The toxicity based PALs have been calculated for an Industrial Use scenario. The Industrial Use scenario is applicable to sites at the NTS based on future land-use scenarios as presented in Section A.1.2.3 and agreements between NDEP and NNSA/NSO.

The conservative level of $100 \mathrm{ppm}$ for TPH is based on a regulatory mandate from the State of Nevada and is used as a "clean-up" level.

Radiochemistry PALs are based on a scaling of the NCRP 25 mrem/yr dose-based levels (NCRP, 1999) to a conservative $15 \mathrm{mrem} / \mathrm{yr}$ and the recommended levels for certain radionuclides in DOE Order 5400.5 Change 2 (DOE, 1993). These PALs are based on the Construction, Commercial, Industrial land-use scenario provided in the guidance and are appropriate for the NTS based on future land-use scenarios as presented in Section A.1.2.3. These established PALs have been accepted by the regulatory agency for use.

\section{A.1.4.3 Potential Sampling Techniques and Appropriate Analytical Methods}

As discussed in Section A.1.4.1, the collection, measurement, and analytical methods will be selected so results will be generated for all of the suspected contaminants as well as all other possible contaminants. This effort will include field screening, soil sampling, and laboratory analysis to determine the presence of COPCs and extent of identified COCs.

Waste characterization sampling and analysis has been included to support the decision-making process for waste management, and to ensure an efficient field program. Specific analyses required for the disposal of IDW are identified in Section 5.0. 


\section{A.1.4.3.1 Field Screening}

Field-screening activities may be conducted for the following analytes and/or parameters:

- Alpha and Beta/Gamma Radiation - Handheld radiological survey equipment may be used based on process knowledge, previous radiological surveys, and analytical results that detect radiological activity. The radiological (alpha and beta/gamma) FSL of the mean background activity plus two times the standard deviation of the mean background activity collected from undisturbed locations within the vicinity of the site (Adams, 1998).

- Gamma Radiation - Gamma spectroscopy, or an equivalent instrument or method, may be used based on process knowledge, previous radiological surveys, and previous analytical results indicate the potential for gamma-emitting radionuclides to be present.

- VOCs - A photoionization detector, or an equivalent instrument or method, may be used to conduct headspace analysis because VOCs are commonly used in degreasers and based on process knowledge decontamination/degreasing activities were potentially conducted at many of the CASs. The VOC FSL is established as 20 ppm or 2.5 times background, whichever is greater.

- $T P H$ - A gas chromatograph, or an equivalent instrument or method, may be used because TPH may be present as a result of decontaminating drilling and farm equipment. The TPH FSL is established as $75 \mathrm{ppm}$.

- Phosphates - A phosphate detection kit, or an equivalent instrument or method, may be used because phosphates are commonly used in detergents and fertilizers and based on process knowledge, decontamination/degreasing activities were potentially conducted at some of the CASs as well as fertilizers used on crops used in animal studies.

Based on the results of previous CAU investigations and common NTS practices, the aforementioned field-screening techniques may be applied during the Decision I and Decision II sampling activities. These field-screening techniques will provide semiquantitative data that can be used to guide soil sampling activities.

\section{A.1.4.3.2 Soil Sampling}

Auguring, direct-push, excavation, drilling, or other appropriate sampling methods will be used to collect soil samples for laboratory analysis. Sample collection and handling activities will be conducted in accordance with the approved procedures. 


\section{A.1.4.3.3 Radiological Walk-Overs and Scanning/Swipe Sampling}

A radiological survey will be conducted for alpha, and beta/gamma-emitting radionuclides at CAS 06-07-01 on the surface soil within the fenced perimeter of the Area 6 Decontamination Facility. The radiological survey will identify locations potentially contaminated with radionuclides that may require sampling.

Radiological scanning and swipe sampling may be conducted on drain pipes, tanks, etc. for purposes of waste management and future release status. A handheld detector such as an NE Technologies Electra or equivalent instrument, will be used to scan the item of interest. If contamination is indicated, swipe samples will be collected and counted.

\section{A.1.4.3.4 Video Survey}

Video surveys will be conducted using a commercial camera system to locate and inspect septic system piping. The video survey will allow a visual assessment of the integrity of the septic system and piping by identifying obvious breaches, unexpected branchings (i.e., tie-ins or off-shoots), open joints, and the presence of material. The septic system piping can be inspected and physically verified to the extent practicable by tracking the camera head inside the piping network. The video survey will not be possible on piping with inside diameters less than $3 \mathrm{in}$. and may not be possible if there is limited access, pipe damage, blockage, or other factors. Material found in the piping that is representative of the former operations conducted at the CAS will be sampled.

\section{A.1.4.3.5 Concrete Sampling}

Samples of concrete will be collected from the concrete decontamination pads located inside and outside of Building 6-605 at CAS 06-07-01. Additional concrete samples may be collected from other pads and/or sumps if biasing factors suggest the need. Samples will be collected from areas of suspected or known contamination identified by the radiological survey and from processes knowledge and field observations (e.g., staining). 


\section{A.1.4.3.6 Analytical Program}

The analytical program for CAU 543 shown in Table A.1-4 was developed based on the suspected-contaminant information presented in Section A.1.1. The critical and noncritical COPCs identified for CAU 543 vary with each CAS and/or component and are listed in Table A.1-1.

The critical COPCs are given greater importance in the decision-making process relative to other COPCs. For this reason, more stringent performance criteria are specified for critical analyte data quality indicators (Section 6.0). Noncritical COPCs are defined as classes of contaminants that include all the analytes reported from the respective analytical methods that have PALs; those analytes are listed in Table A.1-5 for the various analytical methods proposed for this CAI. The noncritical COPCs also aid in reducing the uncertainty concerning the history and potential releases from the CASs and help in the accurate evaluation of potential contamination. If a COPC, either critical or noncritical, is detected in any sample at a concentration above the respective PAL, the COPC will be identified as a COC. During Decision II sampling and analysis, all COCs are considered critical parameters. Section 3.0 and Section 6.0 of the CAIP provide the analytical methods and laboratory performance requirements (e.g., detection limits, precision, and accuracy) to be followed during this CAI. Sample volumes are laboratory- and method-specific and will be determined in accordance with laboratory requirements. Specific analyses required for the disposal of IDW are identified in Section 5.0 of this CAIP. Analytical requirements (e.g., methods, detection limits, precision, and accuracy) are specified in the Industrial Sites QAPP (NNSA/NV, 2002), unless superseded by the CAIP. These requirements will ensure that laboratory analyses are sufficient to detect contamination in samples at concentrations exceeding the MRL. Specific analyses, if any, required for the disposal of IDW are identified in Section 5.0 of the CAIP.

For sampling performed to define the extent of contamination (Decision II), samples will be collected and analyzed only for those COCs identified in samples collected to resolve Decision I. However, if samples are collected to define the extent of contamination prior to nature of contamination data becoming available, the extent samples will be analyzed for the full list parameters given for that CAS. For samples collected to define the extent of contamination, critical analytes are the COCs identified during the Decision I activities that exceed PALs. 


\section{Table A.1-4 \\ Analytical Methods for CAU 543 \\ (Includes Environmental and Waste Characterization Analyses)}

\begin{tabular}{|c|c|c|}
\hline \multirow{2}{*}{ Analytical Parameter ${ }^{a}$} & \multicolumn{2}{|c|}{ Analytical Method } \\
\hline & Liquid & Solid/Sludge \\
\hline Total Volatile Organic Compounds & SW-846 8260B ${ }^{\mathrm{C}}$ & SW-846 $8260 \mathrm{~B}^{\mathrm{C}}$ \\
\hline TCLP Volatile Organic Compounds & SW-846 8260B & SW-846 8260B \\
\hline Total Semivolatile Organic Compounds & SW-846 $8270 C^{c}$ & SW-846 $8270 C^{c}$ \\
\hline TCLP Semivolatile Organic Compounds & SW-846 8270C & SW-846 8270C \\
\hline Total Metals & $\begin{array}{l}\text { SW-846 6010B } \\
(\text { mercury - 7470A }\end{array}$ & $\begin{array}{l}\text { SW-846 6010B } \\
\left(\text { mercury - 7471 } A^{c}\right)\end{array}$ \\
\hline TCLP Metals & SW-846 6010B/7470A & SW-846 6010B/7471A \\
\hline Polychlorinated Biphenyls & SW-846 $8082^{\mathrm{C}}$ & SW-846 $8082^{C}$ \\
\hline Total Petroleum Hydrocarbons $\left(\mathrm{C}_{6}-\mathrm{C}_{38}\right)$ & SW-846 8015B ${ }^{\mathrm{C}}$ (modified) & SW-846 8015B ${ }^{\mathrm{C}}$ (modified) \\
\hline Total Pesticides & SW $8468081^{\mathrm{C}}$ & SW $8468081^{c}$ \\
\hline Total Herbicides & SW $8468151 A^{c}$ & SW $8468151 A^{c}$ \\
\hline $\begin{array}{l}\text { Gamma Spectroscopy (to include Cesium-137, Cobalt-60, } \\
\text { and Americium-241 }{ }^{b} \text { ) }\end{array}$ & EPA Procedure $901.1^{\mathrm{d}}$ & HASL- $300^{\mathrm{e}}$ \\
\hline Strontium-90 & ASTM D5811-00 & HASL- $300^{\mathrm{e}}$ \\
\hline Isotopic Uranium & ASTM D3972-02 ${ }^{g}$ & ASTM E1000-02 \\
\hline Isotopic Plutonium & ASTM D3865-02 & ASTM C1001-00 \\
\hline
\end{tabular}

${ }^{a}$ If the volume of material is limited, prioritization of the analyses will be necessary.

${ }^{b}$ If americium-241 is detected above the minimum detectable activity, isotopic americium-241 analysis may also be performed on sample.

${ }^{\mathrm{c}}$ EPA Test Methods for Evaluating Solid Waste, Physical/Chemical Methods, 3rd Edition, Parts 1-4, SW-846 (EPA, 1996)

${ }^{\mathrm{d}}$ Prescribed Procedure for Measurements of Radioactivity in Drinking Water (EPA, 1980)

${ }^{\mathrm{e}}$ The Procedures Manual of the Environmental Measurements Laboratory, HASL-300 (DOE, 1997)

${ }^{f}$ Standard Test Method for Strontium-90 in Water (ASTM, 2000a)

${ }^{9}$ Standard Test Method for Isotopic Uranium in Water by Radiochemistry (ASTM, 2002b)

${ }^{\mathrm{h}}$ Standard Test Method for Radiochemical Determination of Uranium Isotopes in Soil by Alpha Spectroscopy (ASTM, 2002c)

'Standard Test Method for Plutonium in Water (ASTM, 2002a)

${ }^{j}$ Standard Test Method for Radiochemical Determination of Plutonium in Soil by Alpha Spectroscopy (ASTM, 2000b)

ASTM $=$ American Society of Testing and Materials

SW $=$ Solid Waste

TCLP = Toxicity Characteristic Leaching Procedure 
Table A.1-5

Laboratory Target Analytes for Nature of Contamination (Decision I) Sampling

\begin{tabular}{|c|c|c|c|c|c|}
\hline VOC & SVOC & TPH & РCB & Metals & Radionuclides \\
\hline $\begin{array}{l}\text { 1,1,1-Trichloroethane } \\
\text { 1,1,1,2-Tetrachloroethane } \\
\text { 1,1,2,2-Tetrachloroethane } \\
\text { 1,1,2-Trichloroethane } \\
\text { 1,1-Dichloroethane } \\
\text { 1,1-Dichloroethene } \\
\text { cis-1,2-Dichloroethene } \\
\text { trans-1,2-Dichloroethene } \\
\text { 1,2-Dichloroethane } \\
\text { 1,2-Dichloropropane } \\
\text { 1,2,3-Trichloropropane } \\
\text { 1,2,4-Trimethylbenzene } \\
\text { 1,2-Dibromo-3-chloropropane } \\
\text { 1,2-Dibromoethane } \\
\text { 1,3,5-Trimethylbenzene } \\
\text { cis-1,3-Dichloropropene } \\
\text { trans-1,3-Dichloropropene } \\
\text { 2-Butanone } \\
\text { 2-Chlorotoluene } \\
\text { 4-Methyl-2-pentanone } \\
\text { Acetone } \\
\text { Benzene } \\
\text { Bromobenzene } \\
\text { Bromochloromethane } \\
\text { Bromodichloromethane } \\
\text { Bromoform } \\
\text { Bromomethane } \\
\text { Carbon disulfide } \\
\text { Carbon tetrachloride } \\
\text { Chlorobenzene } \\
\text { Chloroethane } \\
\text { Chloroform } \\
\text { Chloromethane } \\
\text { Dibromochloromethane } \\
\text { Dibromomethane } \\
\text { Dichlorodifluoromethane } \\
\text { Ethylbenzene } \\
\text { Isopropylbenzene } \\
\text { lodomethane } \\
\text { Methyl tertiary butyl ether } \\
\text { Methylene chloride } \\
\text { N-Butylbenzene } \\
\text { N-Propylbenzene } \\
\text { sec-Butylbenzene } \\
\text { Styrene } \\
\text { tert-Butylbenzene } \\
\text { Tetrachloroethene } \\
\text { Toluene } \\
\text { Trichloroethene } \\
\text { Trichlorofluoromethane } \\
\text { Trichlorotrifluoroethane } \\
\text { Vinyl acetate } \\
\text { Vinyl chloride } \\
\text { Xylene }\end{array}$ & $\begin{array}{l}\text { 1,2,4-Trichlorobenzene }{ }^{a} \\
\text { 1,2-Dichlorobenzene } \\
\text { 1,3-Dichlorobenzene } \\
\text { 1,4-Dichlorobenzene } \\
\text { 2,4,5-Trichlorophenol } \\
\text { 2,4,6-Trichlorophenol } \\
\text { 2,4-Dichlorophenol } \\
\text { 2,4-Dimethylphenol } \\
\text { 2,4-Dinitrophenol } \\
\text { 2,4-Dinitrotoluene } \\
\text { 2,6-Dinitrotoluene } \\
\text { 2-Chloronaphthalene } \\
\text { 2-Chlorophenol } \\
\text { 2-Methylphenol } \\
\text { 2-Nitroaniline } \\
\text { 3,3'-Dichlorobenzidine } \\
\text { 4-Bromophenyl phenyl ether } \\
\text { 4-Chloroaniline } \\
\text { 4-Methylphenol } \\
\text { 4-Nitrophenol } \\
\text { Acenaphthene } \\
\text { Acenaphthylene } \\
\text { Aniline } \\
\text { Anthracene } \\
\text { Benzo(a)anthracene } \\
\text { Benzo(a)pyrene } \\
\text { Benzo(b)fluoranthene } \\
\text { Benzo(g,h,i)perylene } \\
\text { Benzo(k)fluoranthene } \\
\text { Benzoic Acid } \\
\text { Benzyl Alcohol } \\
\text { Bis(2-chloroethoxy) methane } \\
\text { Bis(2-chloroethyl)ether } \\
\text { Bis(2-chloroisopropyl)ether } \\
\text { Bis(2-ethylhexyl) phthalate } \\
\text { Butyl benzyl phthalate } \\
\text { Carbazole } \\
\text { Chrysene } \\
\text { Dibenzo(a,h)anthracene } \\
\text { Dibenzofuran } \\
\text { Diethyl Phthalate } \\
\text { Dimethyl Phthalate } \\
\text { Di-n-butyl Phthalate } \\
\text { Di-n-octyl Phthalate } \\
\text { Fluoranthene } \\
\text { Fluorene } \\
\text { Hexachlorobenzene } \\
\text { Hexachlorobutadiene } \\
\text { Hexachlorocyclopentadiene } \\
\text { Hexachloroethane } \\
\text { Indeno(1,2,3-cd)pyrene } \\
\text { Isophorone } \\
\text { Naphthalene } \\
\text { Nitrobenzene } \\
\text { N-Nitroso-di-n-propylamine } \\
\text { N-Nitrosodimethylamine } \\
\text { N-Nitrosodiphenylamine } \\
\text { Pentachlorophenol } \\
\text { Phenanthrene } \\
\text { Phenol } \\
\text { Pyrene } \\
\text { Pyridine }\end{array}$ & $\begin{array}{l}\text { Total Petroleum } \\
\text { Hydrocarbons } \\
\left(C^{6}-C^{38}\right) \\
\text { DRO, GRO }\end{array}$ & $\begin{array}{l}\text { Aroclor-1016 } \\
\text { Aroclor-1221 } \\
\text { Aroclor-1232 } \\
\text { Aroclor-1242 } \\
\text { Aroclor-1248 } \\
\text { Aroclor-1254 } \\
\text { Aroclor-1260 }\end{array}$ & $\begin{array}{l}\text { Arsenic } \\
\text { Barium } \\
\text { Beryllium } \\
\text { Cadmium } \\
\text { Chromium } \\
\text { Lead } \\
\text { Mercury } \\
\text { Selenium } \\
\text { Silver }\end{array}$ & $\begin{array}{l}\text { Americium-241 } \\
\text { Cesium-137 } \\
\text { Cobalt-60 } \\
\text { Eu-152 } \\
\text { Nb-94 } \\
\text { Radium } \\
\text { Thorium } \\
\text { Plutonium-238 } \\
\text { Plutonium-239/240 } \\
\text { Strontium-90 } \\
\text { Uranium-234 } \\
\text { Uranium-235 } \\
\text { Uranium-238 } \\
\text { Other parameters: } \\
\text { Gamma-emitting } \\
\text { radionuclides }\end{array}$ \\
\hline
\end{tabular}

${ }^{\mathrm{a}}$ May be reported with VOCs 


\section{A.1.5 Step 4 - Define the Boundaries of the Study}

The purpose of this step is to define the target population of interest, specify the spatial and temporal features of the population that are pertinent for decision making, determine practical constraints on data collection, and define the scale of decision making relevant to target populations for Decision I and Decision II decisions.

\section{A.1.5.1 Define the Target Population}

Decision I target populations represent locations within the CAS that contain COCs, if present. Decision II target populations are locations adjacent to the $\mathrm{COC}$ plume where $\mathrm{COC}$ concentrations are less than PALs.

\section{A.1.5.2 Identify the Spatial and Temporal Boundaries}

The spatial boundaries for each CAS are defined as the vertical or horizontal boundaries beyond which the CSM and/or the scope of the investigation will require reevaluation.

The spatial boundaries that apply to Decision I (determine the presence of a COC) are the sample locations selected to satisfy the criteria for Decision I samples. In general, geographic boundaries are defined by the area impacted from releases attributed to each CAS. Intrusive activities are not intended to extend into the boundaries of neighboring areas of environmental concern (e.g., other CASs). The spatial boundaries for the components each CAS are listed in Table A.1-6.

Temporal boundaries are those time constraints set up by weather conditions and project schedules. Significant temporal constraints due to weather conditions are not expected. Moist weather may place constraints on sampling and field screening contaminated soils because of the attenuating effect of moisture in samples (e.g., alpha-emitting radionuclides). There are no time constraints on collected samples as environmental conditions at all sites will not significantly change in the near future and conditions would have stabilized over the years since the sites were last used.

\section{A.1.5.3 Identify Practical Constraints}

Practical constraints include underground and overhead utilities, rough terrain, access restrictions such as scheduling conflicts at the NTS, posted contamination area requirements, physical barriers 
Table A.1-6

\section{CAU 543 Spatial Boundaries}

\begin{tabular}{|c|c|c|}
\hline \multirow{2}{*}{ CAS/Component } & \multicolumn{2}{|l|}{ Spatial Boundary } \\
\hline & Horizontal & Vertical \\
\hline Area 6 Decontamination Facility & $\begin{array}{l}\text { 50-ft buffer around perimeter fence for general CAS; } \\
\text { The TPH Use Restriction on northwest corner of Building 6-605 will not be entered. }\end{array}$ & A maximum of $20 \mathrm{ft}$ bgs \\
\hline Septic and Process waste line piping at all CASs & $20 \mathrm{ft}$ laterally from piping & A maximum of $20 \mathrm{ft} \mathrm{bgs}$ \\
\hline Septic Tanks and Sumps at Area 6 & $20 \mathrm{ft}$ laterally from edges of tank features and all junctions & A maximum of $20 \mathrm{ft} \mathrm{bgs}$ \\
\hline Aboveground Storage Tank & $\begin{array}{l}\text { Includes a } 20 \text {-ft lateral buffer from sides of the AST berm; length of piping to holding pen } \\
\text { and Building } 15-06 \text {; drain box at holding pen; distribution box; } 20 \text {-ft lateral boundary from } \\
\text { all these components }\end{array}$ & A maximum of $20 \mathrm{ft}$ bgs \\
\hline Liquid Manure Tank & $\begin{array}{l}20-\mathrm{ft} \text { lateral buffer around edges of tank; } 20-\mathrm{ft} \text { lateral buffer around concrete pad; } 20-\mathrm{ft} \\
\text { lateral from any piping }\end{array}$ & A maximum of $20 \mathrm{ft} \mathrm{bgs}$ \\
\hline Contaminated Sump & $20-\mathrm{ft}$ lateral buffer around edges of the sump & A maximum of $30 \mathrm{ft}$ bgs \\
\hline Clean-Out Boxes; Drain Boxes; Collection Boxes & 15 -ft lateral buffer from the sides of features & A maximum of $20 \mathrm{ft} \mathrm{bgs}$ \\
\hline Leachfields & 50-ft lateral buffer from leach lines & $\begin{array}{l}\text { A maximum of } 30 \mathrm{ft} \text { bgs from } \\
\text { base of piping }\end{array}$ \\
\hline Contaminated Surface Soil Areas & 50-ft lateral buffer from designated boundaries (e.g., fence, rope, posted area) & A maximum of $20 \mathrm{ft} \mathrm{bgs}$ \\
\hline
\end{tabular}


(e.g., fences, steep slopes), and areas requiring authorized access. Underground utilities surveys will be conducted at each CAS prior to the start of investigation activities to determine if utilities exist, and, if so, determine the limit of spatial boundaries for intrusive activities. No other practical constraints have been identified.

\section{A.1.5.4 Define the Scale of Decision Making}

The scale of decision making in Decision I is defined as each CAS. The scale of decision making for Decision II is defined as a contiguous area contaminated with any COC originating from the CAS.

\section{A.1.6 Step 5 - Develop a Decision Rule}

This step integrates outputs from the previous step with the inputs developed in this step into a decision rule ("If..., then...") statement. This rule describes the conditions under which possible alternative actions would be chosen.

\section{A.1.6.1 Specify the Population Parameter}

The population parameter for Decision I data collected from biased sample locations is the maximum observed concentration of each COC within the target population.

The population parameter for Decision II will be the observed concentration of each unbounded COC in any sample.

\section{A.1.6.2 Choose an Action Level}

Action levels are defined as the PALs and discussed in Section A.1.4.2. As appropriate, action levels may also be the unrestricted release criteria given in the NV/YMP RadCon Manual (DOE/NV, 2000c).

\section{A.1.6.3 Decision Rule}

If the concentration of any COPC in a target population exceeds the PAL for the COPC in a Decision I sample, then that COPC is identified as a COC and sampling to define the extent of contamination (Decision II) will be conducted. If the Site Supervisor determines that an indicator 
(e.g., staining) is present, then Decision II sampling may be conducted. If all COPC concentrations are less than the corresponding PALs, then the decision will be no further action.

Sample analyses conducted during this investigation will be sufficient to characterize the contents, if any, of a septic tank for clean closure according to the NAC.

If the observed population parameter of any COC in a Decision II sample exceeds the PALs, then additional samples will be collected. If all observed COC population parameters are less than PALs, then the decision will be that the extent of contamination has been defined in the lateral and/or vertical direction(s).

If contamination is inconsistent with the CSM or extends beyond the spatial boundaries, then work will be suspended and the investigation strategy reevaluated. If contamination is consistent with the CSM and is within spatial boundaries, then the decision will be made to continue sampling to define the extent.

\section{A.1.7 Step 6 - Specify the Tolerable Limits on Decision Errors}

The approach for Decision I and II sampling for all CASs, with the exception of CAS 15-23-01 and the Contamination Area component of CAS 06-07-01, relies on biased sampling locations. Only validated analytical results (quantitative data) will be used to determine if COCs are present (Decision I) or the extent of a COC (Decision II), unless otherwise stated. The baseline condition (i.e., null hypothesis) and alternative condition for Decision I are:

- Baseline condition - A COC is present

- Alternative condition - A COC is not present

The baseline condition (i.e., null hypothesis) and alternative condition for Decision II are:

- Baseline condition - The extent of a COC has not been defined

- Alternative condition - The extent of a COC has been defined

Decisions and/or criteria have an alpha (false rejection) or beta (false acceptance) error associated with their determination (discussed in the following subsections). Since quantitative data are individually compared to action levels, statistical evaluations of the data such as averages or confidence intervals are not appropriate. 
Statistical analysis is will be used in addition to bias sampling to determine the number Decision I sample locations at CAS 15-23-01 and the storage yard at CAS 06-07-01. Inputting parameters into standard statistical equations for calculating the required number of sample locations at these CASs resulted in 9 sample locations at CAS 15-23-01 and 16 sample locations at CAS 06-07-01.

\section{A.1.7.1 False Rejection Decision Error}

The false rejection (alpha) decision error would mean:

- Deciding that a COC is not present when it actually is (Decision I)

- Deciding that the extent of a COC has been defined when it has not (Decision II)

In both cases, the consequence is the increased risk to human health and the environment.

In Decision I, a false rejection decision error (where consequences are more severe) is controlled by meeting these criteria: (1) having a high degree of confidence that the sample locations selected will identify COCs if present anywhere within the CAS, and (2) having a high degree of confidence that analyses conducted will be sufficient to detect any COCs present in the samples. For Decision II, this error is reduced by: (1) having a high degree of confidence that the sample locations selected will identify the extent of COCs; (2) having a high degree of confidence that analyses conducted will be sufficient to detect any COCs present in the samples; and (3) having a high degree of confidence that the dataset is of sufficient quality and completeness.

To satisfy the first criterion, Decision I data and samples will be collected in areas most likely to be contaminated by any COCs. In Decision II, data collection will sample areas that represent the lateral and vertical extent of contamination. The following characteristics are considered during both Decisions to accomplish the first criterion:

- Source and location of release

- Chemical nature and fate properties

- Physical properties and migration pathways

- Hydrologic drivers

These characteristics were considered during the development of the CSMs and selection of sampling locations. The biasing factors listed in Section A.1.6.1 will be used to further ensure that these criteria are met. 
To satisfy the second criterion, all Decision I samples will be analyzed for the chemical and radiological parameters listed in Table A.1-4. Decision II samples will be analyzed for those chemical and radiological parameters that identified unbounded COCs.

To satisfy the third criterion, the entire dataset, as well as individual sample results, will be assessed against the DQIs of precision, accuracy, comparability, completeness, and representativeness defined in the Industrial Sites QAPP (NNSA/NV, 2002). The goal for the DQI of completeness is that 90 percent of the critical COPC results are valid for every sample. Critical COPCs are defined as those contaminants that are known or expected to be present within a CAS. Critical parameters/analytes identified as COPCs are discussed in Section A.1.1. In addition, sensitivity has been included as a DQI for laboratory analyses. Site-specific DQIs are discussed in more detail in Section 6.0 of the CAIP. Strict adherence to established procedures and QA/QC protocol also protects against false negatives.

\section{A.1.7.2 False Positive Decision Error}

The false positive (acceptance of the null or beta) decision error would mean one of the following:

- Deciding that a COC is present when it is not (Decision I)

- Accepting that the extent of a COC has not been defined when it really has (Decision II)

These errors result in increased costs for unnecessary characterization or corrective actions.

The false positive decision error is controlled by protecting against false positive analytical results. False positive results are typically attributed to laboratory and/or sampling/handling errors. Quality control samples such as field blanks, trip blanks, laboratory control samples, and method blanks minimize the risk of a false positive analytical result. Other measures include proper decontamination of sampling equipment and using certified clean sample containers to avoid crosscontamination.

\section{A.1.7.3 Statistical Model}

In the absence of biasing factors for surface contamination, sampling locations need to determined with the use of a randomization technique. Chapter 9 of EPA SW-846 defines the methodology suggested to determine the sufficient number of samples to be taken to ensure a 90 percent confidence 
level in the COPC concentration. This method is used here to determine the number of random sampling locations required at CAS 15-23-01 and the Contamination Area component of CAS 06-07-01. SW-846 makes the following assumptions:

- A regulatory threshold for the contaminant of concern has been defined.

- The COPC is uniformly distributed throughout the waste form.

- The concentration of the COPC is normally distributed.

- There is a positive analytical result for the contaminant of concern in each sample.

- The regulatory threshold exceeds the mean concentration of the contaminant.

Although some of these assumptions may not hold true for the radiological contaminants, the EPA SW-846 method can still be used to predict the number of samples required to reach the 90 percent confidence level. If the 90 percent confidence level of the mean concentration of the contaminant exceeds the regulatory threshold, the solid waste is assumed to contain the contaminant of concern at a hazardous level. Appendix A.3 provides a discussion of assumptions and the calculations used to determine the number of samples required at CAS 06-07-01, Contaminated Area and CAS 15-23-01.

\section{A.1.7.4 Quality Assurance/Quality Control}

Radiological survey instruments and field-screening equipment will be calibrated and checked in accordance with the manufacturer's instructions or approved procedures.

Quality control samples will be collected as required by the Industrial Sites QAPP (NNSA/NV, 2002) and in accordance with established procedures. The required QC samples include:

- Trip blanks (1 per sample cooler containing VOC environmental samples)

- Equipment blanks (1 per sampling event for each type of decontamination procedure)

- Source blanks (1 per source lot per sampling event)

- Field duplicates (minimum of 1 per matrix per 20 environmental samples, or 1 per CAS if less than 20 are collected)

- Field blanks (minimum of 1 per 20 environmental samples, or 1 per CAS if less than 20 are collected per sampling day)

- MS/MSD (minimum of 1 per matrix per 20 environmental samples or 1 per CAS if less than 20 are collected; not required for all radionuclide measurements) 
Additional QC samples may be submitted based on site conditions.

\section{A.1.8 Step 7 - Optimize the Design for Obtaining Data}

This section presents an overview of the resource-effective strategy planned to obtain the data required to meet the project DQOs developed in previous six steps. Section A.1.8.1 provides general investigation strategy, and Section A.1.8.2 provides the detailed sampling approach to resolve the decision statement for CAU 543. As additional data or information is obtained, this step will be reevaluated and refined, if necessary, to reduce uncertainty and increase the confidence that the nature and extent of contamination is accurately defined.

\section{A.1.8.1 General Investigation Strategy}

The initial activities to be conducted will be a visual inspection and photodocumentation of the area of all CASs and CAS components. A judgmental or biased sampling design (a nonprobabilistic approach) has been developed for the general investigation strategy for CAU 543 with the exception of CAS 15-23-01 and the Contamination Area component of CAS 06-07-01 in which a combination of judgmental and random (probabilistic) sampling will be implemented. This sampling approach focuses on specific sampling locations to support the decision statements presented in Section A.1.3 and the migration and release pathways identified in the CSMs. Chapter 7 of the EPA QA/G-4HW guidance document (EPA, 2000a) allows for judgmental (biased) sampling when chosen locations are based on expert knowledge of contamination sources and history of the sites.

For the CASs or CAS components that include septic tanks, distribution boxes, USTs, and ASTs, the initial visual inspection will also include accessing and opening tanks to document details on the tank contents. Additional liquid and solid samples will be collected for waste characterization purposes from these components if present and accessible. Based on the results of the radiological survey of the concrete surfaces, swipes may be collected and analyzed on site for removable radiological contaminants. Based on biasing factors, scabbling of the concrete may be conducted to collect samples for off-site analysis of chemical and radiological contaminants.

Most of the CASs and components of CASs have elements of an effluent collection and distribution system that involves subsurface piping. At these areas a video survey will be conducted from within the associated piping to identify residual material, breaches, or unknown tie-ins. Site conditions and 
conditions of the piping may not allow a 100 percent video survey. If the video survey identifies breaches and/or conditions that may have provided a means for effluent reach to the surrounding soils, then Decision I samples may be collected at those locations for laboratory analysis. If residual material is present and of an adequate volume, a sample will be collected for analysis. If no breaches or residual effluent is identified during the survey, than Decision I sampling adjacent to and within the buried portions of the pipelines will not be necessary.

Following the initial visual inspection and/or video surveys, Decision I soil sample locations will be identified and collected for laboratory analysis. The selection of theses locations considers the biasing factors listed in Section A.1.4.1 and features of the CSM. If site conditions are encountered during the Decision I surface sampling or the video survey results suggest shallow subsurface contamination exists, then subsurface Decision I samples may be collected immediately. Decision I surface and shallow subsurface soil samples will be collected for laboratory analysis of the parameters identified in Section A.1.4.3.6.

Decision II (step-out) sampling locations at each CAS will be selected based on the outer boundary sample locations where COCs were detected in the Decision I samples. Decision II locations will also be selected based on the elements of the CSM and other biasing factors. If biasing factors indicate a COC extends beyond the planned step-outs (i.e, field screening), locations may be modified or additional Decision II samples may be collected from incremental step-out locations as determined by the project staff. Initial step-outs will be at least as deep as the vertical extent of contamination defined at the Decision I location and the depth of the incremental step-outs will be based on the deepest contamination observed at all locations. For subsurface sampling locations, generally two consecutive soil samples with results below field-screening action levels are required to define the vertical extent of contamination. Generally, the uppermost "clean" sample from each location will be submitted for laboratory analysis. Contaminants determined not to be present in Decision I samples may be eliminated from Decision II analytical suites.

Due to the nature of buried features possibly present (e.g., structures and utilities), sample locations may be relocated, based upon actual field conditions, review of engineering drawings, and information obtained during the site visit. However, the new locations will meet the decision needs and criteria stipulated in Section A.1.4.1. 


\section{A.1.8.2 Detailed Investigation Strategy}

The following sections discuss the more detailed CAS- and CAS component-specific investigation activities, including proposed sample locations.

\section{A.1.8.2.1 CAS 06-07-01, Area 6 Decontamination Facility}

The detailed investigation strategy for the Area 6 Decontamination Facility will be discussed based on the various components of the CAS including effluent collection system, decontamination pads, Building 6-605, and the Contamination Area.

Effluent Collection/Distribution System - Prior to Decision I sampling, a video mole survey will be performed on as much of the subsurface piping as practical to identify breaks, residual materials, and location of sumps/tanks. Excavation may be performed to locate the subsurface sumps and septic tanks. If any breaches are identified within the piping, excavation and Decision I subsurface soil sampling will be implemented. Additional Decision I soil sampling will be performed at the junctions of subsurface piping at Sump 1, Sump 2, and the two septic tanks associated with Buildings 6-605 and 6-607 assuming all these components are still present. Decision I soil samples will be collected near the base of the sumps and septic tanks to capture potential leaks. Decision I samples will be collected on any residual sediments or liquids identified in the piping, sumps, and septic tanks for waste management purposes. See Figure A.1-7 for proposed sample locations.

Decision II step-out samples may be collected, as described in Section A.1.8.1. The Site Supervisor will determine if Decision II sampling is appropriate based on biasing factors, primarily field screening of Decision I samples.

Decontamination Pads - Decision I soil samples will be collected from the surface soils surrounding the edges of the outdoor concrete pads adjacent to Buildings 6-605 and 6-606 to capture potential contaminated run-off. The concrete will be scabbled at visibly stained areas and concrete samples will be collected for Decision I analysis. Decision I samples will be collected from any residual sediment still remaining within the pad trench or floor drains. Figure A.1-7 shows the proposed sample locations. 


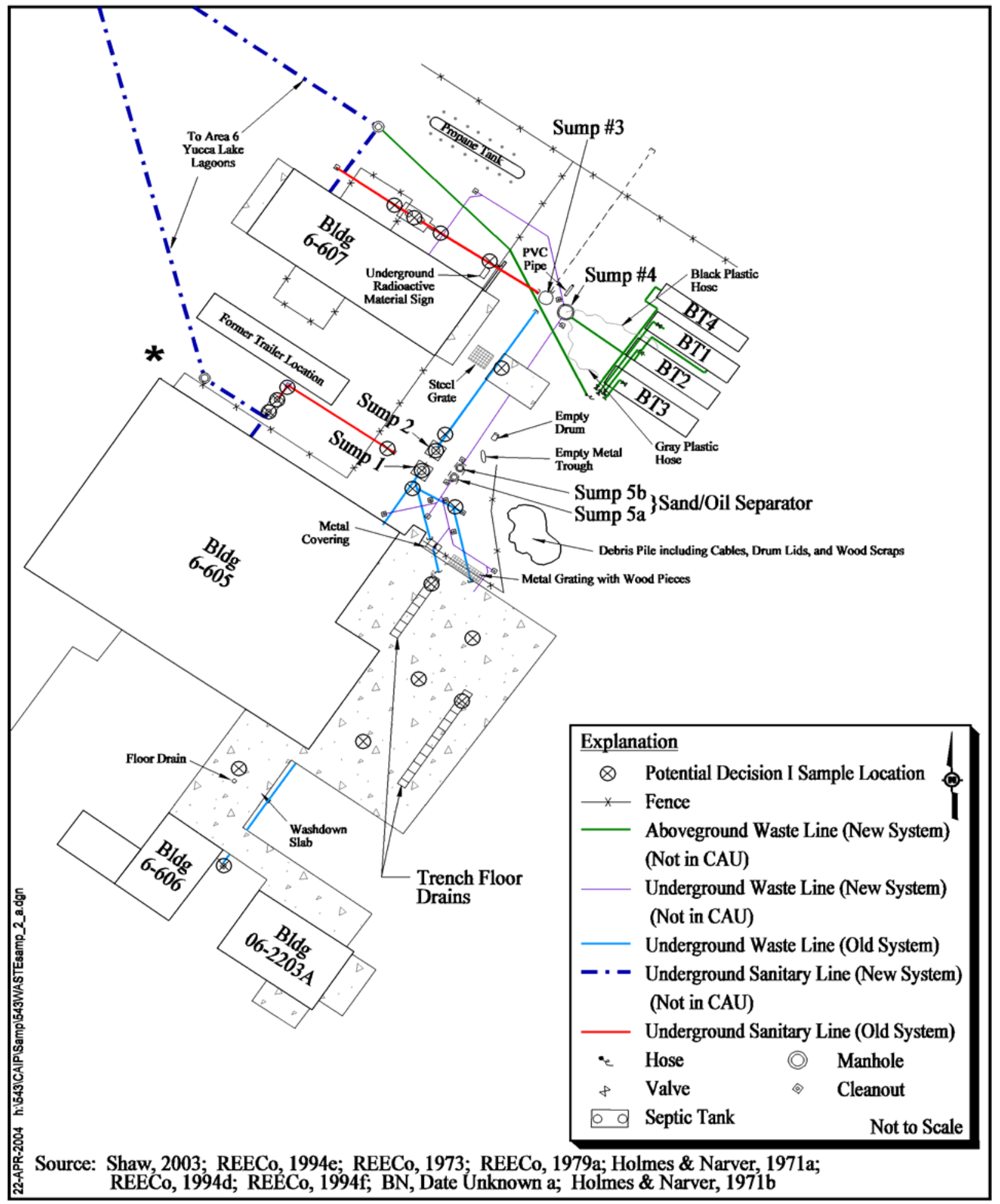

Figure A.1-7

CAU 543, CAS 06-07-01, Decon Pad, Septic System, and Piping Proposed Decision I Sample Locations 
Decision II step-out samples may be collected, as described in Section A.1.8.1. The Site Supervisor will determine if Decision II sampling is appropriate based on biasing factors, primarily field screening of Decision I samples.

Building 6-605 - Decision I sample collection will be implemented for components within Building 6-605 to determine future waste disposal actions of building materials. All drains, trenches, and piping within the building will be inspected for remaining residual sediments/materials. If residual material is present, Decision I samples will be collected. If biasing factors indicate the need, concrete within the building floors may be scabbled and sampled for analysis. The remaining caustic dip tanks will be accessed and inspected for residual materials. Any remaining liquids and/or solids present will be collected for Decision I sample analysis. Radiological scanning and swipe collection will be conducted during Decision I sampling to determine the status of building materials and equipment for free release criteria. It is expected that the nature of Decision I sampling will most likely provide sufficient information on the extent of contamination for Building 6-605 so that Decision II sampling may not be necessary. See Figure A.1-8 for proposed sample locations.

Contamination Area - A statistically based and biased sampling approach will be implemented during Decision I sampling of the surface soils within the area designated as the Contamination Area. A total of 16 random surface samples has been determined sufficient to satisfy the criteria of a 90 percent confidence level in the COPC concentration as determined by the methodology defined in Chapter 9 of EPA SW-846. The 16 sample locations have been randomly generated using the VSP program and will be within the boundary of the Contamination Area. Figure A.1-9 shows the proposed surface soil sample locations. Additional biased samples may be collected where deemed appropriate.

Decision II step-out samples may be collected, as described in Section A.1.8.1. The Site Supervisor will determine if Decision II sampling is appropriate based on biasing factors, primarily field screening of Decision I samples.

\section{A.1.8.2.2 Area 15 EPA Farm}

Discussions of the detailed investigation strategy for the Area 15 EPA Farm will be grouped based on related or similar CASs. The groups will be the septic system and leachfield (CASs 15-04-01 and 


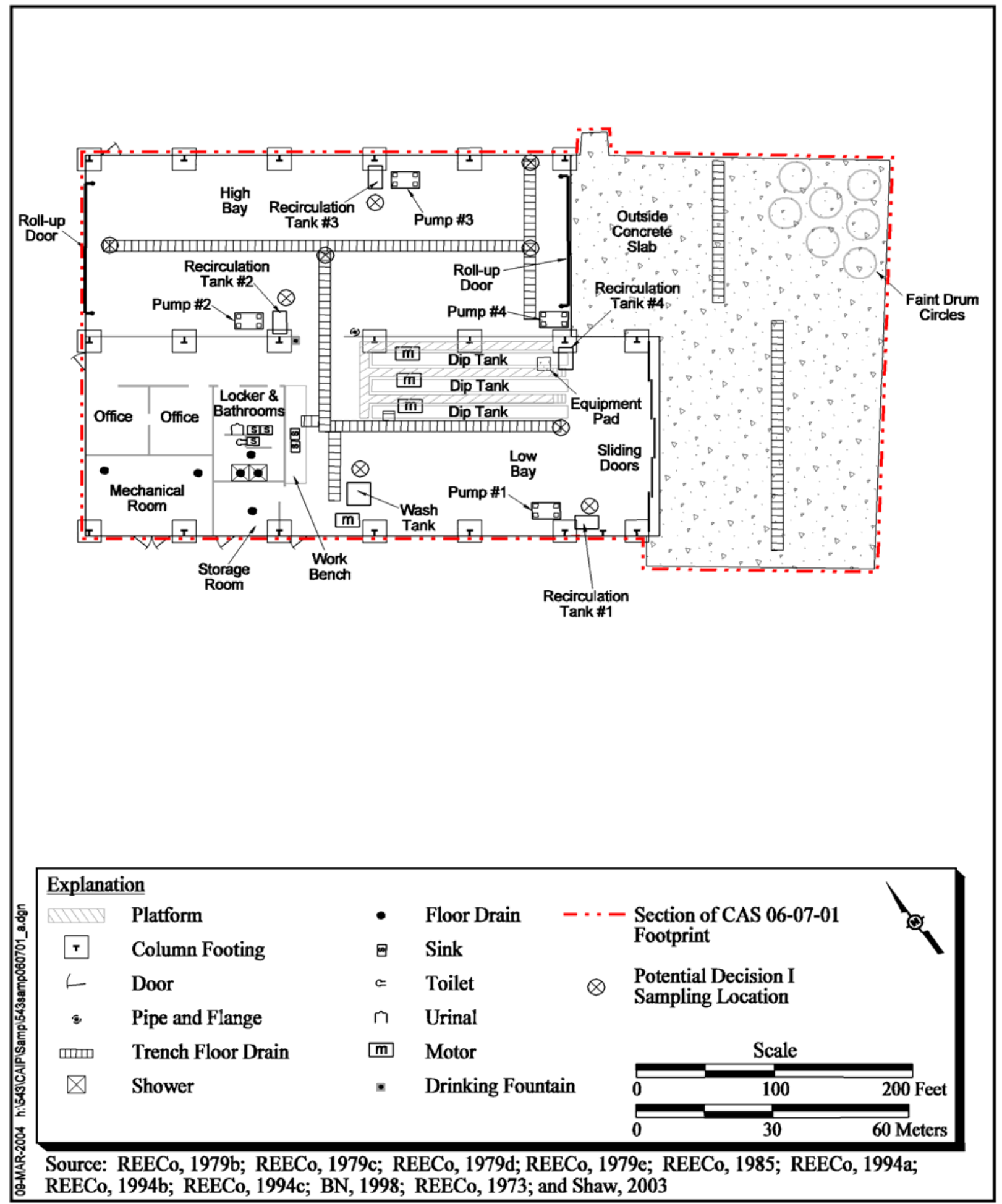

Figure A.1-8

CAU 543, CAS 06-07-01, Potential Decision I Sample Locations 


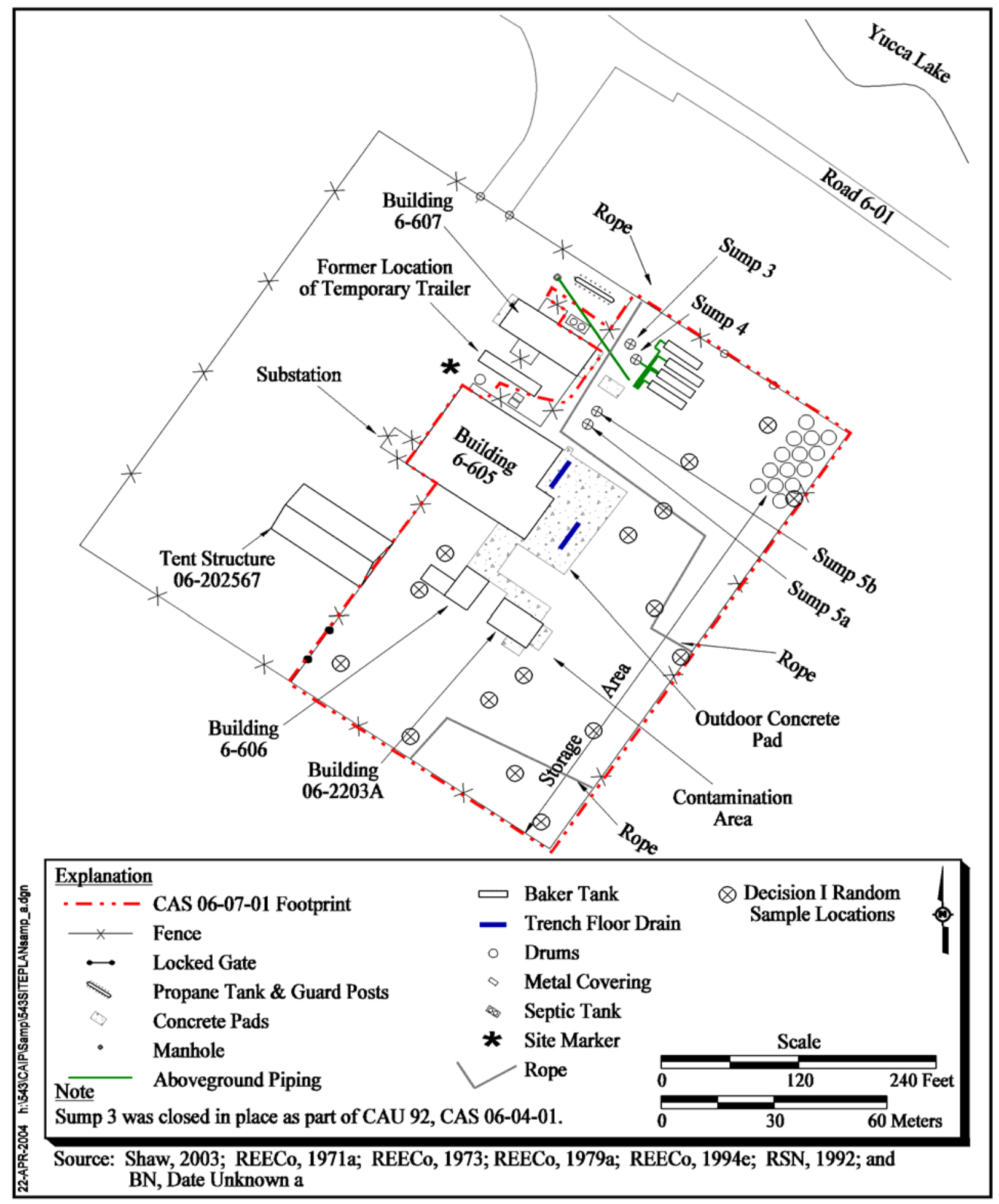

Figure A.1-9

CAU 543, CAS 06-07-01, Decon Pad, Proposed Decision I Random Sampling Locations 
15-05-01); liquid manure underground storage tank and concrete pad (15-08-01); the contaminated sump and AST (CASs 15-23-03 and 15-01-03); and the decontamination area (CAS 15-23-01).

\section{Septic Tank and Leachfield System, CASs 15-04-01 and 15-05-01}

Prior to Decision I sampling, a video mole survey will be performed to identify residual materials, breaches, location of the septic tank if still present, and the end of distribution lines. Excavation will be performed to access and inspect the septic tank and distribution box for integrity. Decision I soil sampling will be conducted below the septic tank inlet and outlet, the outlet from Building 15-06, the distribution box inlet/outlet, below the tank and box, and locations of identified breaches within any part of the system. Decision I activities at the Leachfield will consist of excavating to locate the boundaries of the leachfield, exposing the midpoint, and the proximal and distal ends of the associated perforated distribution pipes, and collecting biased samples from soil beneath the leachrock/native soil interface at the midpoint, and proximal and distal ends of the distribution pipes. If the interface cannot be identified, then samples will be collected directly beneath the distribution pipes.

The contents of the septic tank and distribution box will be sampled during Decision I for waste management purposes. Any remaining residual materials within piping or the clean out will also be sampled provided enough volume is present. Figure A.1-10 and Figure A.1-11 show the proposed sampling locations for the septic tank and leachfield systems, respectively.

Decision II step-out samples may be collected, as described in Section A.1.8.1. The Site Supervisor will determine if Decision II sampling is appropriate based on biasing factors, primarily field screening of Decision I samples.

\section{CAS 15-08-01, Liquid Manure Tank}

Prior to collecting Decision I samples, a video mole survey will be performed to identify if piping connects to the tank or is broken and if residual materials are present. Decision I subsurface soil samples will be collected from below the manure tank inlet and outlet and base of tank and at identified breaches within the piping. Surface soil samples will be collected at the liquid waste transfer point. Decision I surface soil samples will be collected at the outfall located to the south of 


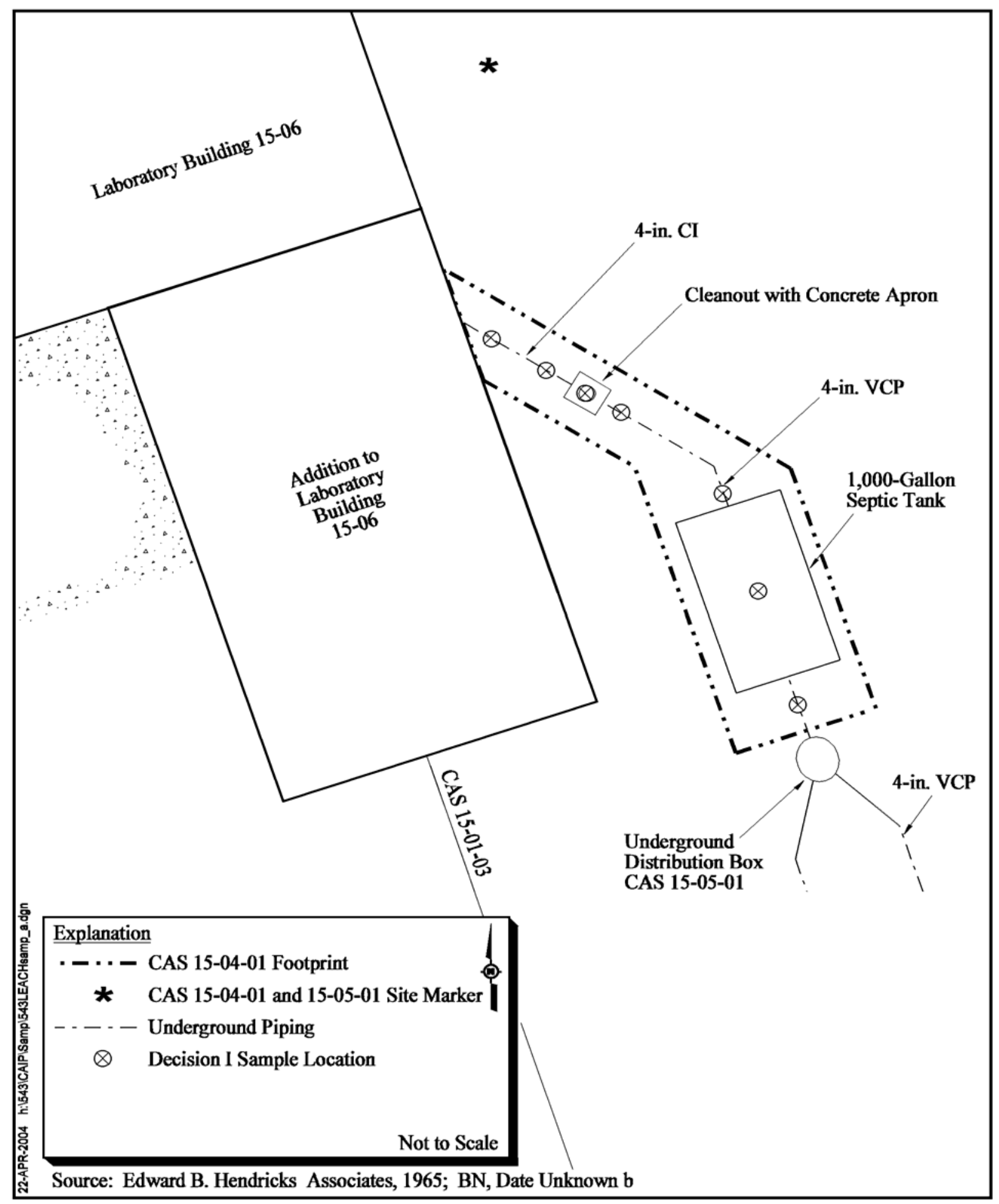

Figure A.1-10

CAU 543, CAS 15-04-01, Septic Tank

Proposed Decision I Sample Locations 


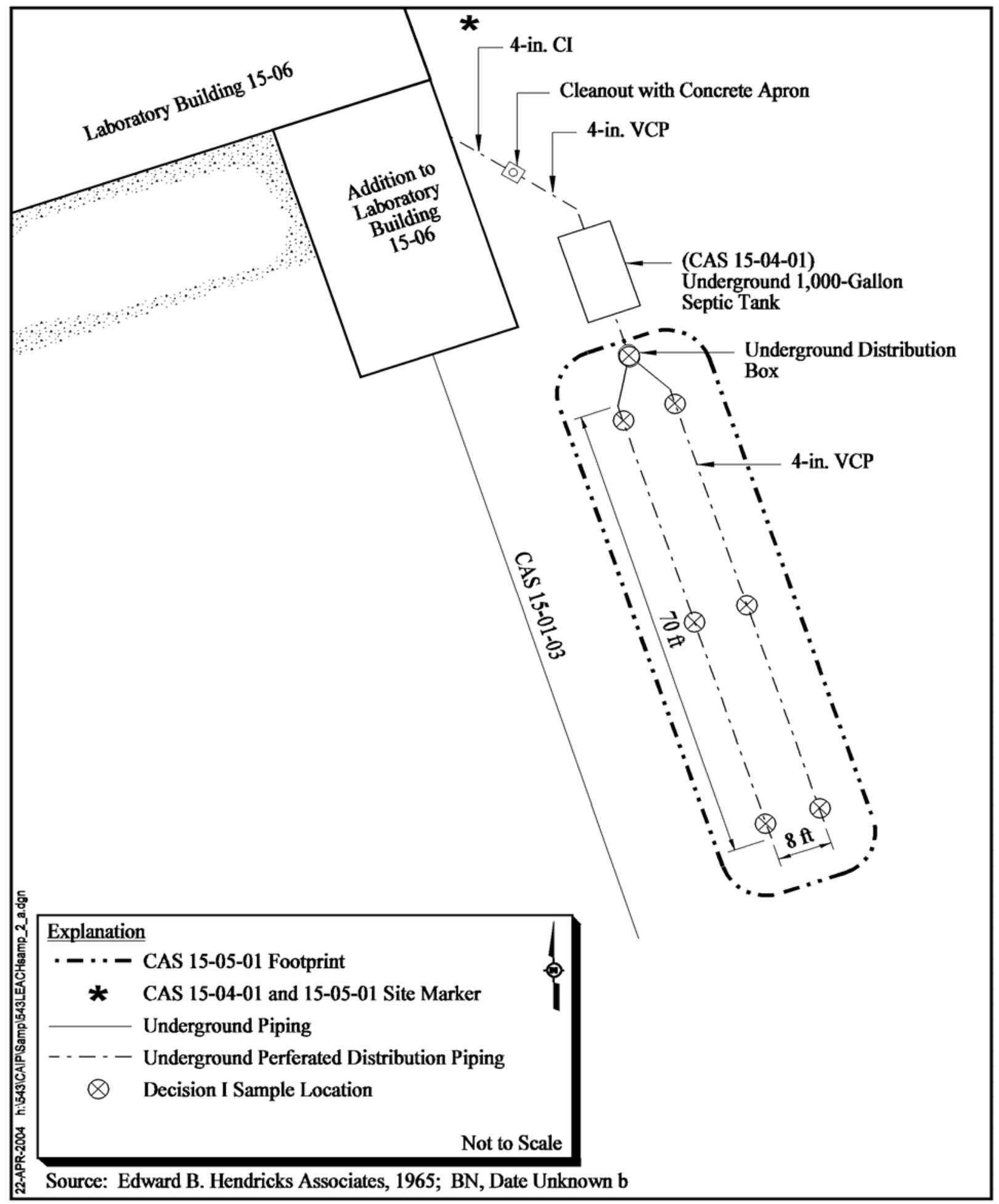

Figure A.1-11

CAU 543, CAS 15-05-01, Leachfield

Proposed Decision I Sample Locations 
the tank. Tank contents will be sampled if present. Figure A.1-12 shows the proposed sample locations.

Decision II step-out samples may be collected, as described in Section A.1.8.1. The Site Supervisor will determine if Decision II sampling is appropriate based on biasing factors, primarily field screening of Decision I samples.

\section{CAS 15-23-03, Contaminated Sump}

Prior to Decision I sampling, a video mole will be performed along the piping from the sump outfall to the distribution box to identify breaches and residual material. Decision I subsurface soil samples will be collected below the distribution box at the effluent end and breaches in the piping. The piping will be sampled to determine if transite. Decision I soil samples will be collected below the outfall pipe and within the sump.

Decision II step-out samples may be collected, as described in Section A.1.8.1. The Site Supervisor will determine if Decision II sampling is appropriate based on biasing factors, primarily field screening of Decision I samples. Figure A.1-13 shows the proposed sample locations for Decision I.

\section{CAS 15-01-03, Aboveground Storage Tank}

Decision I investigation at this CAS includes the soils at the AST, the AST, and piping that extends from the AST to the distribution box to Building 15-06 and the holding pen concrete drain box. Prior to sampling, a video mole survey will be performed to identify breaches or residual materials. Decision subsurface soil samples will be collected at identified breaks and the distribution box inlet and outlet. Surface soil samples will be collected from the base of the AST near the tank staining and at the transfer point of liquid waste. The piping at the transfer point will be sampled for potential ACM. Soil beneath the junctions at the concrete drain box and Building 15-06 will also be sampled during Decision I investigation.

Decision II step-out samples may be collected, as described in Section A.1.8.1. The Site Supervisor will determine if Decision II sampling is appropriate based on biasing factors, primarily field screening of Decision I samples. Figure A.1-14 shows the proposed sample locations for Decision I. 


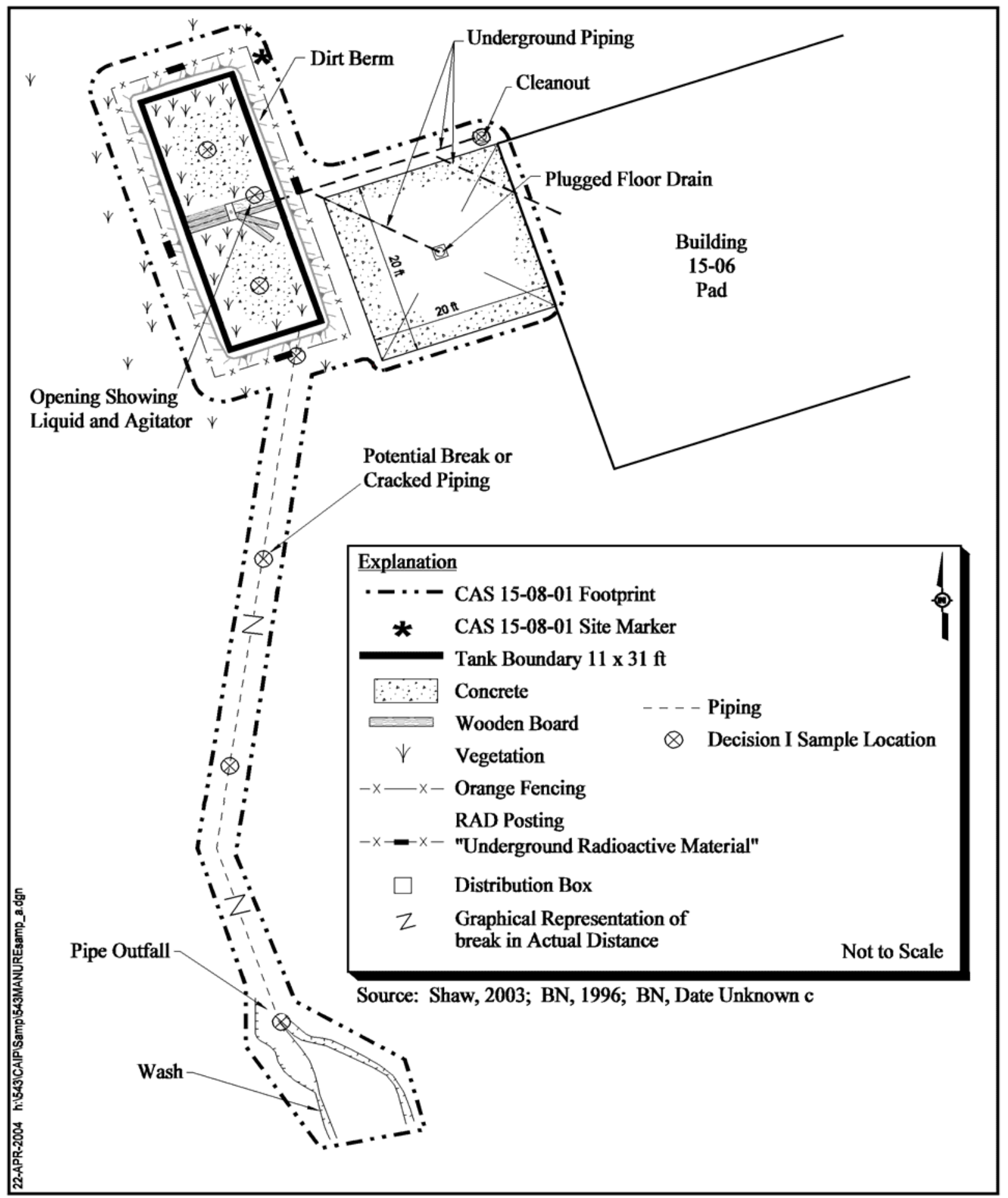

Figure A.1-12

CAU 543, CAS 15-08-01, Liquid Manure Tank Proposed Decision I Sample Locations 


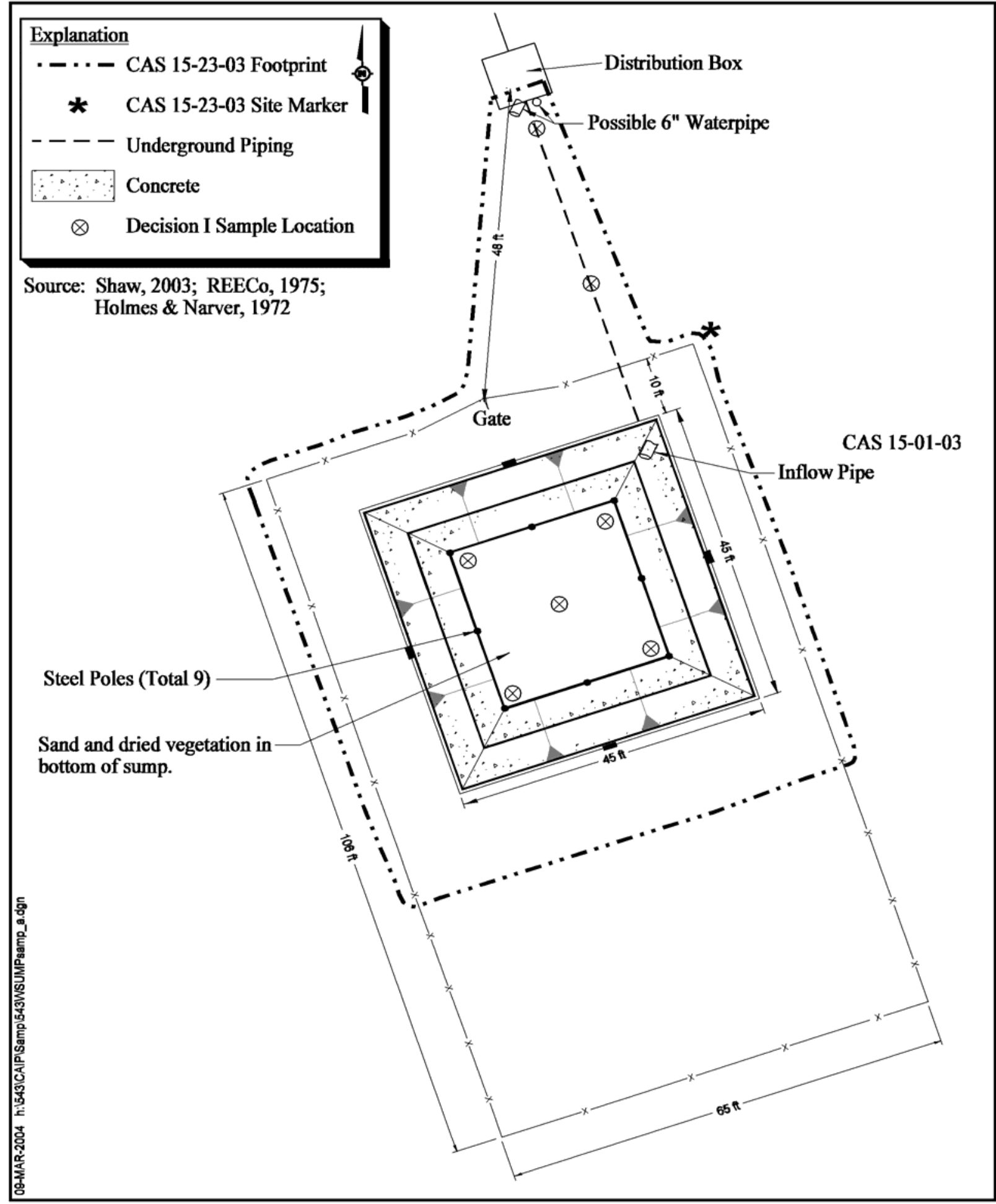

Figure A.1-13

CAU 543, CAS 15-23-03, Contaminated Sump, Piping Proposed Decision I Sample Locations 


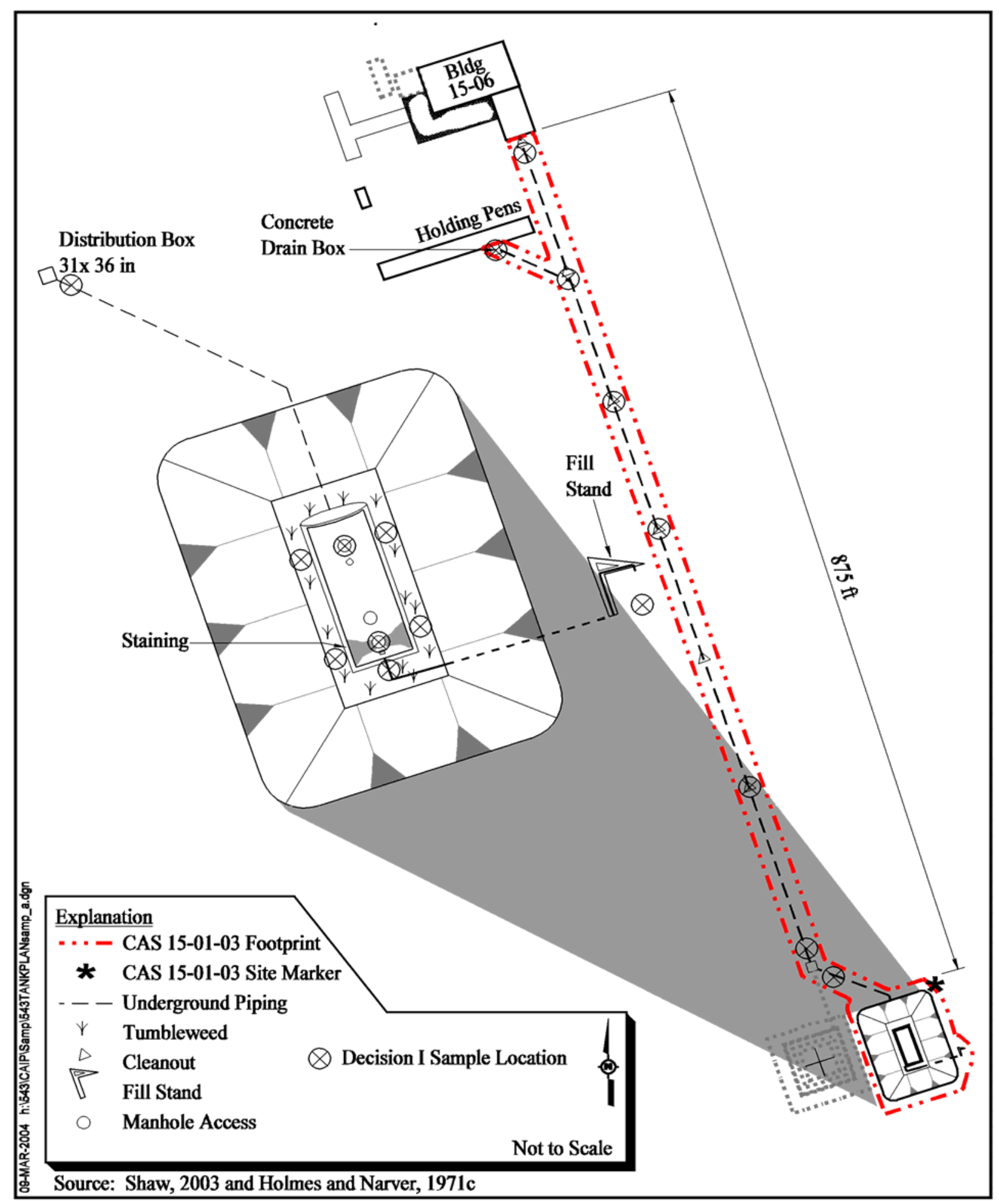

Figure A.1-14

CAU 543, CAS 15-01-03, Aboveground Storage Tank Proposed Decision I Sample Locations 


\section{CAS 15-23-01, Decontamination Pad}

The Decision I investigation involves the surface soils located beneath and surrounding the PSP located on the ground. A radiological survey will be performed to determine if elevated radiological conditions exist. A shallow excavation may be performed to determine if a sump is present below the PSP. If biased sample locations are observed, Decision I soil samples will be collected. A statistical sampling approach is being implemented for the surface soils at this CAS. A total of 9 surface samples will be collected within the area of the PSP to meet the 90 percent confidence level in the COPC concentration as determined by the methodology defined in Chapter 9 of EPA SW-846.

Decision II step-out samples may be collected, as described in Section A.1.8.1. The Site Supervisor will determine if Decision II sampling is appropriate based on biasing factors, primarily field screening of Decision I samples. Figure A.1-15 shows the proposed random sampling locations. 


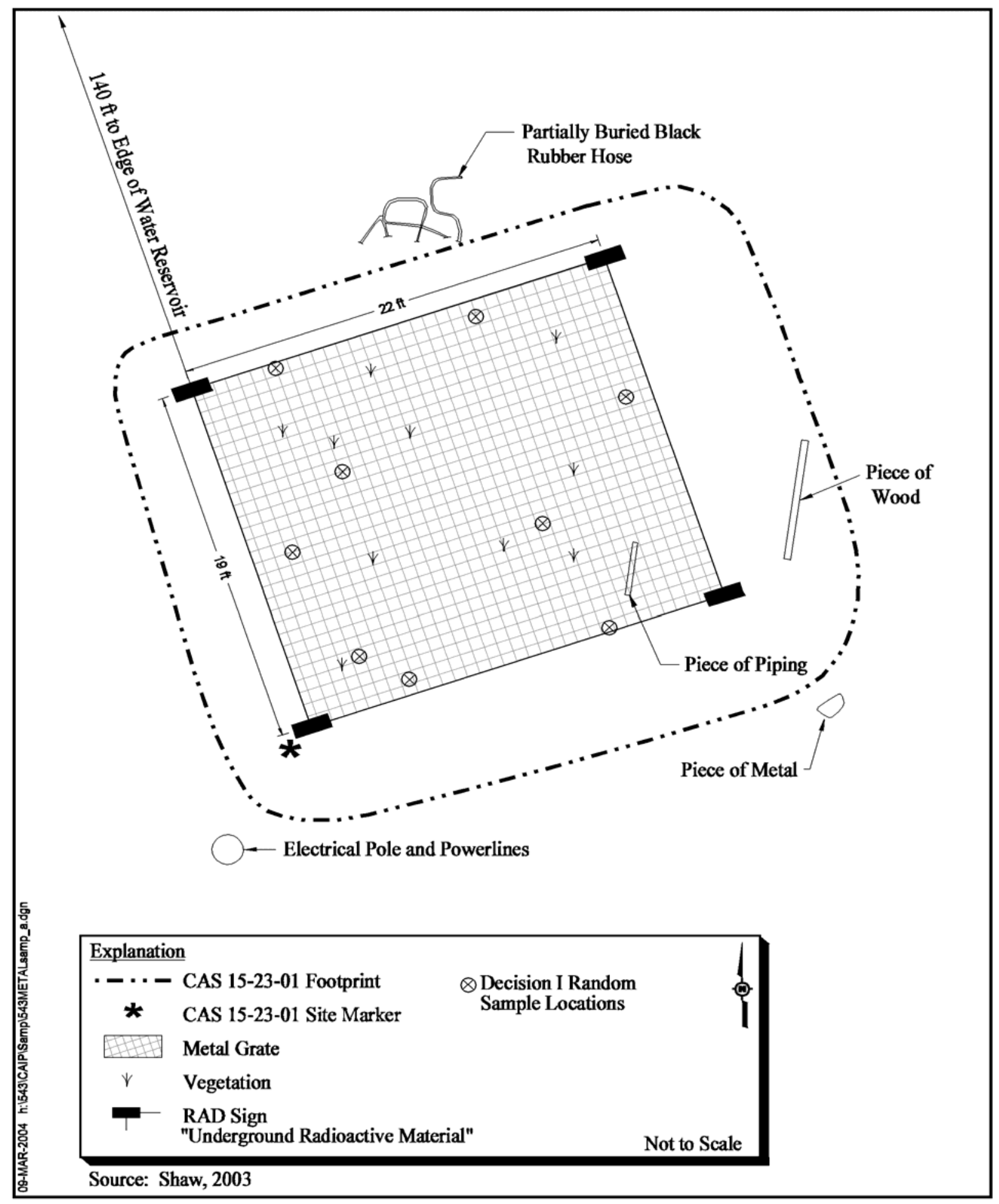

Figure A.1-15

CAU 543, CAS 15-23-01, Underground Radioactive Material Area Proposed Decision I Random Sample Locations 


\section{A.1.9 References}

ASTM, see American Society for Testing and Materials.

Adams, S., IT Corporation. 1998. Memorandum to R. McCall (Science Applications International Corporation) regarding methodology for determining action levels for CAU 407, the Roller Coaster RADSAFE Area, 16 June. Las Vegas, NV.

Adams, S., IT Corporation. 2002. Memorandum to B. Iverson (GeoTrans) entitled, "Radiological Contaminants of Potential Concern (COPC) at the Bunkers of Corrective Action Unit (CAU) 204,” 29 March. Las Vegas, NV.

American Society for Testing and Materials. 2000a. Standard Test Method for Strontium-90 in Water, D5811-2000. Philadelphia, PA.

American Society for Testing and Materials. 2000b. Standard Test Method for Radiochemical Determination of Plutonium in Soil by Alpha Spectroscopy, C1001-2000. Philadelphia, PA.

American Society for Testing and Materials. 2002a. Standard Test Method for Plutonium in Water, D3865-02. Philadelphia, PA.

American Society for Testing and Materials. 2002b. Standard Test Method for Isotopic Uranium in Water by Radiochemistry, D3972-2002. Philadelphia, PA.

American Society for Testing and Materials. 2002c. Standard Test Method for Radiochemical Determination of Uranium Isotopes in Soil by Alpha Spectroscopy, E1000-2002.

Philadelphia, PA.

BN, see Bechtel Nevada.

Barth, D., U.S. Environmental Protection Agency (Retired). 2003. Telecon with A. Steed (SAIC) and B. Iverson (GeoTrans) regarding the EPA Farm, 13 February. Las Vegas, NV.

Bechtel Nevada. Date Unknown a. Engineering drawing SK-006-03-C11 entitled, "CP and Yucca Lake Area Existing Sewage Systems Site Plan.” Las Vegas, NV.

Bechtel Nevada. Date Unknown b. Engineering drawing JS-015-06-M4 entitled, "Nevada Test Site Area 15 Demolition Plans CAU 95 EPA Farm Building 15-06 Soil, Waste and Vent Plan." Mercury, NV: Archives \& Records Center.

Bechtel Nevada. Date Unknown c. Engineering drawing JS-015-06-C1 entitled, "Nevada Test Site Area 15, Demolition Plans CAU 95 EPA Farm Building 15-06 Site Plan,” Las Vegas, NV. 
Bechtel Nevada. 1996. Engineering drawing JS-015-139-E1 entitled, "Nevada Test Site - Area 15, NTS Retrofit Power Metering System In-House Energy Management Systems (Phase 1B) Plans, Elevation \& Diagram," Las Vegas, NV.

Bechtel Nevada. 1998. Engineering drawing FWR-98223-A06-M1 entitled, "Decon Shower Decontamination Facility Bldg 605 Demolition and Floor Plan," 3 November. Las Vegas, NV.

Betrand, K., Bechtel Nevada. 2003. Record of Telecon with B. Bailey (Shaw) regarding CAS 06-07-01, 2 June. Las Vegas, NV.

Bicker, A.E., Reynolds Electrical \& Engineering Co., Inc. 1988. Memorandum to B.P. Smith (REECo) entitled, "Control of Effluent from Building 650 and the Area 6 Decontamination Facility," 17 November. Las Vegas, NV.

Bielawski, J.P., Reynolds Electrical \& Engineering Co., Inc. 1994. Memorandum to D.S. Gilmore (REECo) entitled, "Decontamination Facility Upper Wastewater System Construction Approval and Additional Sampling," 23 March. Las Vegas, NV.

Bingham, F.E., Reynolds Electrical \& Engineering Co., Inc. 1990. Memorandum to the Files entitled, "Telephone Call from David McNelis on Area 6 Decontamination (Decon) Pond Problem," 3 January. Las Vegas, NV.

Bingham, F.E., Reynolds Electrical \& Engineering Co., Inc. 1992. Letter to J.D. Stewart (DOE/NTSO) entitled, "Survey of Nevada Test Site (NTS) Abandoned Septic Tank Systems Tiger Team Finding SW/CF-3," 2 January. Las Vegas, NV.

Bingham, F.E., Reynolds Electrical \& Engineering Co., Inc. 1993a. Letter to D.R. Elle (DOE/NV) entitled, "Closure of Tiger Team Finding SW/CF-06," 7 July. Las Vegas, NV.

Bingham, F.E., Reynolds Electrical \& Engineering Co., Inc. 1993b. Letter to D.R. Elle (DOE/NV) entitled, "Decontamination Facility Sampling Plan," 22 September. Las Vegas, NV.

Boehlecke, R.F., Science Applications International Corporation. 1997. Electronic transmittal to E. Shupp (IT) entitled, "MSDS's." Las Vegas, NV.

Boyd, G., Bechtel Nevada. 2003. Record of Telecon with A. Steed (SAIC) regarding CAS 06-07-01, 17 March. Las Vegas, NV.

DOE, see U.S. Department of Energy.

DOE/NV, see U.S. Department of Energy, Nevada Operations Office.

DRI, see Desert Research Institute. 
Desert Research Institute. 1988. CERCLA Preliminary Assessment of DOE's Nevada Operations Office Nuclear Weapons Testing Areas, Volume I. Prepared for the U.S. Department of Energy, Nevada Operations Office. Las Vegas, NV: Water Resources Center.

Desert Research Institute. 1993. Tritium Activities in Selected Wells on the Nevada Test Site, DOE/NV/10845-20. Publication Number 45104. Prepared by B.F Lyles. Las Vegas, NV: Water Resources Center.

Desert Research Institute. 1994. A Class III Cultural Resource Reconnaissance of a Proposed Soil Treatability Pilot Plant Site at the EPA Farm, Area 15, Nevada Test Site, Nye County, Nevada, SR090893-1. Prepared by N.G. Goldenberg, W.G. Johnson, and A.R. McLane. Las Vegas, NV.

EG\&G/EM, see EG\&E Energy Measurements.

EPA, see U.S. Environmental Protection Agency.

EG\&G Energy Measurements. 1986. An Aerial Radiological Survey of Areas 12, 15, 17 and 19 Nevada Test Site, EGG-10282-1113. Prepared by J.E. Jobst. Las Vegas, NV.

ERDA, see U.S. Energy Research and Development Administration.

Edward B. Hendricks Associates. 1965a. Engineering drawing NV-35-08-01.2 entitled, “Area 15 U.S.P.H.S. Field Research Complex Laboratory Mech-Elect. Plot Plan,” 29 November. Mercury, NV: Archives \& Records Center.

Edward B. Hendricks Associates. 1965b. As-built engineering drawing NV-35-08-01.2 Sheet M-2 entitled, “Area 15 N.T.S. U.S.P.H.S. Field Research Complex Laboratory Plumbing Plan,” 30 November. Las Vegas, NV.

Edward B. Hendricks Associates. 1965c. As-built engineering drawing NV-35-08-01.1 Sheet A-1 entitled, "Area 15 N.T.S. U.S.P.H.S. Field Research Complex Plan,” 2 December. Las Vegas, NV.

Elle, D.R., U.S. Department of Energy, Nevada Operations Office. 1994. Letter to P.J. Liebendorfer (NDEP) entitled, "Summary of Activities at the Area 6 Decontamination (A-6 Decon) Laundry Facility," 19 April. Las Vegas, NV.

Frazier, A.R., Reynolds Electrical \& Engineering Co., Inc. 1987. Letter to W. McCurry (NDEP) entitled, "Description of NTS and TTR Septic Tank and Leachfield Systems," 21 December. Las Vegas, NV.

Giles, K., Desert Research Institute. 2003. Telecon with A. Steed (SAIC) and B. Iverson (GeoTrans) regarding the EPA Farm, 6 February. Las Vegas, NV. 
Holmes \& Narver, Inc. 1971a. Engineering drawing 006-029-C2 entitled, "Rad-Safe Decontamination Laundry Plot Plan," 23 December. Las Vegas, NV.

Holmes \& Narver, Inc. 1971b. Engineering drawing 006-029-M10 entitled, "Rad-Safe Decontamination Laundry Sanitation \& Waste Drainage Plan,” 23 December. Las Vegas, NV.

Holmes \& Narver, Inc. 1971c. Engineering drawing, 015-094-C3.7 Sheet 6 of 10, entitled "Nevada Test Site - Area 15, Modifications to Bldg. 15-06 - USPHS Farm Plan, Profile, and Details," 17 June. Las Vegas, NV.

Holmes \& Narver, Inc. 1972a. Engineering drawing, 015-094-C3.2, entitled "Nevada Test Site Area 15, Modifications to Bldg. 15-06 - USPHS Farm, Plan, Profile \& Details,” 2 January. Las Vegas, NV

Holmes \& Narver, Inc. 1972b. Engineering drawing, 015-06-M1.1 Sheet 5, entitled, "Nevada Test Site - Area 15, Modifications to Bldg. 15-06 - USPHS Farm Plans - Water \& Drainage Piping,” 2 January. Las Vegas, NV.

Holmes \& Narver, Inc. 1973a. Engineering drawing, 015-06-C1 entitled, "Nevada Test Site Area 15 New EPA Slaughter Facility Grading Plan,” 24 August. Mercury, NV.

Holmes \& Narver, Inc. 1973b. Engineering drawing, 015-06-M2.1 entitled, "Nevada Test Site Area 15 New EPA Slaughter Facility Plumbing Plan \& Sections," 24 August. Mercury, NV.

Holmes \& Narver, Inc. 1974. Engineering drawing, 015-06-M2.1, entitled "Nevada Test Site-Area 15, New EPA Slaughter Facility, Plumbing Plan \& Sections," 6 September. Las Vegas, NV.

Holmes \& Narver, Inc. 1979a. Engineering drawing, Page No. 21, entitled "Area 15 Environmental Protection Agency," 1 April. Las Vegas, NV.

Holmes \& Narver, Inc. 1979b. Engineering drawing, JS-015-06-M2, entitled "Title II EPA Farm Slaughter Facility Mods Water Piping Plan \& Details," 1 March. Las Vegas, NV.

Holmes \& Narver, Inc. 1981. Engineering drawing 006-029-M10.1 entitled, "Rad-Safe Decontamination Laundry Sanitation \& Waste Drainage Plan," 3 May. Las Vegas, NV.

Hopper, R., U.S. Environmental Protection Agency and S. Helleman, D.B. Stephens. 1995. Record of Telecon with L. Tryboski (IT Corporation) regarding the EPA Farm, 3 August. Las Vegas, NV.

Hopper, D., U.S. Environmental Protection Agency. 2003. Meeting with A. Steed (SAIC) and B. Iverson (Geo Trans) regarding the EPA Farm, 4 February. Las Vegas, NV. 
Moore, J., Science Applications International Corporation. 1999. Memorandum to M. Todd (SAIC) entitled, "Background Concentrations for NTS and TTR Soil Samples," 3 February. Las Vegas, NV.

NAC, see Nevada Administrative Code.

NBMG, see Nevada Bureau of Mines and Geology.

NCRP, see National Council on Radiation Protection and Measurements.

NNSA/NV, see U.S. Department of Energy, National Nuclear Security Administration Nevada Operations Office.

National Council on Radiation Protection and Measurements. 1999. Recommended Screening Limits for Contaminated Surface Soil and Review of Factors Relevant to Site-Specific Studies, NCRP Report No. 129. Washington, DC.

Nevada Administrative Code. 2002. NAC 445A, "Water Controls.” Carson City, NV.

Nevada Bureau of Mines and Geology. 1998. Mineral and Energy Resource Assessment of the Nellis Air Force Range, Open-File Report 98-1. Reno, NV.

Nicosia, W.C., Shaw Environmental, Inc. 2003. Memorandum to M. England (SAIC) entitled, "Radiological Land Area Surveys of Various Locations at the Nevada Test Site for Preliminary Assessments," 3 March. Las Vegas, NV.

Olsen, A. Bechtel Nevada. 1997. Correspondence to L. Tryboski (IT Corporation) regarding CAUs at the EPA Farm Facility, 5 August. Las Vegas, NV.

Paradis, L., Company Unknown. 1998. Record of Telecon with L.M. Mercado (SAIC) regarding the status of the Area 6 decon pad, 4 August. Las Vegas, NV.

REECo - See Reynolds Electrical \& Engineering Co., Inc.

RSN, see Raytheon Services Nevada.

Radack, P.M., Reynolds Electrical \& Engineering Co., Inc. 1992. Memorandum to M.B. Brown (REECo) entitled, "Decontamination Facility Septic Tank," 2 June. Las Vegas, NV.

Raytheon Services Nevada. 1992. Engineering drawing JS-006-083-C2 entitled, “Area 6 Yucca Lake Utilities - Water Map,” 29 December. Las Vegas, NV.

Reynolds Electrical \& Engineering Co., Inc. 1971a. Environmental Sciences Decontamination Facility Operations Guide, September. Mercury, NV. 
Reynolds Electrical \& Engineering Co., Inc. 1971b. Ground-level photograph 3296-06 showing Building 6-605, 4 February. Nellis Air Force Base, NV: Remote Sensing Laboratory Photo Library.

Reynolds Electrical \& Engineering Co., Inc. 1973. Engineering drawing SK-6-183 entitled, "Decon Facility Drainage Control Grading Plan," 15 February. Las Vegas, NV.

Reynolds Electrical \& Engineering Co., Inc. 1975a. Engineering Drawing, 15-E.P.A.-C1, entitled "Nevada Test Site - Area 15, E.P.A. Farm Contaminated Waste Disposal System Modification Plan \& Profile - Sections - Details," 10 June. Las Vegas, NV.

Reynolds Electrical \& Engineering Co., Inc. 1975b. Engineering drawing, 15-E.P.A.-E1, entitled, "Nevada Test Site - Area 15, E.P.A. Farm Contaminated Waste Disposal System Elect. Plan Diagram \& Details," 11 June. Las Vegas, NV.

Reynolds Electrical \& Engineering Co., Inc. 1979a. Engineering drawing 6-DD-C1 entitled, "Dyna-Drill Maintenance Shop Plot \& Utility Plan," 29 September. Las Vegas, NV.

Reynolds Electrical \& Engineering Co., Inc. 1979b. Engineering drawing 6-D-A1 entitled, "Rad-Safe Decontamination Facility Architectural - Floor Plan," 5 July. Las Vegas, NV.

Reynolds Electrical \& Engineering Co., Inc. 1979c. Engineering drawing 6-D-S2 entitled, "Rad-Safe Decontamination Facility Floor Slab Drainage Plan \& Sections," 5 July. Las Vegas, NV.

Reynolds Electrical \& Engineering Co., Inc. 1979d. Engineering drawing 6-D-A2 entitled, "Rad-Safe Decontamination Facility Partial Floor Plan, Sect. \& Det's," 5 July. Las Vegas, NV.

Reynolds Electrical \& Engineering Co., Inc. 1979e. Engineering drawing 6-D-M3 entitled, "Rad-Safe Decontamination Facility Plumbing Layout \& Schedule," 5 July. Las Vegas, NV.

Reynolds Electrical \& Engineering Co., Inc. 1979f. Engineering drawing 6-D-M1 entitled, "Rad-Safe Decontamination Facility Piping Layout \& Legend," 2 July. Las Vegas, NV.

Reynolds Electrical \& Engineering Co., Inc. 1985. Engineering drawing 6-605-C1 entitled, "Reline Concrete Drains Decon Facility Bldg 6-605,” 16 April. Las Vegas, NV.

Reynolds Electrical \& Engineering Co., Inc. 1994a. Engineering drawing 6-605-556-S5.1 entitled, "Concrete Floor Repair Decon Facility, Building 6-605 Existing Floor Plan," 10 November. Las Vegas, NV.

Reynolds Electrical \& Engineering Co., Inc. 1994b. Engineering drawing 6-605-556-S6.1 entitled, "Concrete Floor Repair Decon Facility, Building 6-605 Floor Plan," 7 September. Las Vegas, NV. 
Reynolds Electrical \& Engineering Co., Inc. 1994c. Engineering drawing 6-605-556-S9.1 entitled, "Recirculation Tank System Decon Facility, Building 6-605 Floor Plan," 11 July. Las Vegas, NV.

Reynolds Electrical \& Engineering Co., Inc. 1994d. Engineering drawing 6-DF-556-C11.1 entitled, "Upper Wastewater Disposal System Decon Facility, Area 6 Site Plan," 29 October.

Las Vegas, NV.

Reynolds Electrical \& Engineering Co., Inc. 1994e. Engineering drawing 6-DF-556-C3.2 entitled, "Sanitary Sewerage System Decon Facility, Area 6 Site Plan," 27 October. Las Vegas, NV.

Reynolds Electrical \& Engineering Co., Inc. 1994f. Engineering drawing 6-DF-556-10.1 entitled, "Upper Wastewater Disposal System Decon Facility, Area 6 existing/Demolition Plan," 5 October. Las Vegas, NV.

SAIC, see Science Applications International Corporation.

Shaw, see Shaw Environmental, Inc.

SWRHL, see Southwestern Radiological Health Laboratory.

Science Applications International Corporation. 2003. Surface Geophysical Survey Final Report Corrective Action Units Nevada Test Site, May. Prepared for Shaw Environmental, Inc. Harrisburg, PA.

Shaw Environmental, Inc. 2003. CAU 543 Project Files. Las Vegas, NV.

Smith, M. 1991. Site Monitoring/Site Demarcation Checklist: Area 15 Site Dry Well - Feed Storage Bin, 29 May. Las Vegas, NV.

Soong, C., Bechtel Nevada. 2003. Record of Telecon with B. Bailey (Shaw) regarding CAS 06-07-01, 9 June. Las Vegas, NV.

Sorom, E., Reynolds Electrical \& Engineering Co., Inc. 1995. Telecon with L. Tryboski (IT Corporation) regarding the tank at the EPA Farm, 13 July. Las Vegas, NV.

Southwestern Radiological Health Laboratory. 1967. Status of the Nevada Test Site Experimental Farm Summary Report for July 1964-December 1965, SWRHL-36r. Prepared by R.L. Douglas for the U.S. Atomic Energy Commission. Las Vegas, NV: U.S. Public Health Service

USGS, see U.S. Geological Survey.

U.S. Department of Energy. 1988. Environmental Survey Preliminary Report, DOE/EH/OEV-15P, April. Washington, DC: Environment, Safety, and Health Office of Environmental Audit. 
U.S. Department of Energy. 1993. DOE Order 5440.5, Change 2, Radiation Protection of the Public and the Environment. Washington, DC: U.S. Government Printing Office.

U.S. Department of Energy. 1997. Procedures Manual of Environmental Measurements Laboratory, HASL-300, 28th Ed., Vol. I. New York, NY.

U.S. Department of Energy, National Nuclear Security Administration Nevada Operations Office. 2002. Industrial Sites Quality Assurance Project Plan, Nevada Test Site, Nevada, DOE/NV--372-Rev. 3. Las Vegas, NV.

U.S. Department of Energy, Nevada Operations Office. 1984. Safety Assessment of the Area 6 Decontamination Pad and Laundry, DOE/NV/10327-12. Prepared by M.W. Chilton and J.A. Orcutt. Las Vegas, NV.

U.S. Department of Energy, Nevada Operations Office. 1992. RCRA Part B Permit Application for Waste Management Activities at the Nevada Test Site: Section L Potential Solid Waste Management Units, Volume IV. Las Vegas, NV.

U.S. Department of Energy, Nevada Operations Office. 1993. Nevada Test Site Conceptual Site Treatment Plan, October. Las Vegas, NV.

U.S. Department of Energy, Nevada Operations Office. 1995. Preliminary Characterization of Abandoned Septic Tank Systems, Volumes I and II, DOE/NV-414 UC-700. Prepared by Reynolds Electrical \& Engineering Co., Inc. Las Vegas, NV.

U.S. Department of Energy, Nevada Operations Office. 1996. Final Environmental Impact Statement for the Nevada Test Site and Off-Site Locations in the State of Nevada, DOE/EIS 0243. Las Vegas, NV.

U.S. Department of Energy, Nevada Operations Office. 1998a. Closure Report for Decontamination \& Decommissioning (D\&D) Category, Corrective Action Unit 95, EPA Farm Laboratory Building 15-06, Nevada Test Site, DOE/NV-11718-178. Las Vegas, NV.

U.S. Department of Energy, Nevada Operations Office. 1998b. Nevada Test Site Resource Management Plan, DOE/NV--518. Las Vegas, NV.

U.S. Department of Energy, Nevada Operations Office. 1999. Closure Report for Corrective Action Unit 92: Area 6 Decontamination Pond Nevada Test Site, Nevada, DOE/NV/11718-306. Las Vegas, NV.

U.S. Department of Energy, Nevada Operations Office. 2000a. Closure Report for Petroleum Hydrocarbon Release at the Area 6 Decontamination Facility at the Nevada Test Site: Tank 6-605-1 (NDEM \#990204-3304), February. Las Vegas, NV. 
U.S. Department of Energy, Nevada Operations Office. 2000b. Nevada Test Site Contaminated Land Areas Report, Volume I, DOE/NV/11718-481-VOL 1. Las Vegas, NV.

U.S. Department of Energy, Nevada Operations Office. 2000c. NV/YMP Radiological Control Manual, Rev. 4, DOE/NV/11718-079, UC-702. Prepared by A.L. Gile of Bechtel Nevada. Las Vegas, NV.

U.S. Energy Research and Development Administration. 1976. Letter to H.D. Cunningham transmitting the attachment "Disposal Procedures for Contaminated Liquid Waste EPA Farm," Accession numbers NVO173551 and NVO173552, September. Las Vegas, NV: NNSA/NSO Public Reading Facility.

U.S. Environmental Protection Agency. 1973. Status of the Environmental Protection Agency's Nevada Test Site Experimental Dairy Herd January 1, 1969 - December 31, 1970, NERC-LV-539-22. Prepared by D. D. Smith for the U.S. Atomic Energy Commission. Las Vegas, NV.

U.S. Environmental Protection Agency. 1977. Five-Year Summary Report of an Experimental Dairy Herd Maintained on the Nevada Test Site 1971 Through 1975, EMSL-LV-0539-9. Prepared for the U.S. Energy Research and Development Administration. Las Vegas, NV.

U.S. Environmental Protection Agency. 1980. Prescribed Procedures for Measurement of Radioactivity in Drinking Water, EPA 600/4-80-032. Washington, DC.

U.S. Environmental Protection Agency. 1983. Standards for Remedial Actions of Inactive Uranium Processing Sites, Title 40 Code of Federal Regulations, Part 192. Washington, DC.

U.S. Environmental Protection Agency. 1996. Test Methods for Evaluating Solid Waste, Physical/Chemical Methods, SW-846, $3^{\text {rd }}$ Edition, CD-ROM PB97-501928GEI.

Washington, DC.

U.S. Environmental Protection Agency. 2000a. Data Quality Objectives Process for Hazardous Waste Site Investigations, EPA QA/G-4HW. Washington, DC.

U.S. Environmental Protection Agency. 2000b. Guidance on Choosing a Sampling Design for Environmental Data Collection, EPA QA/G-5S. Washington, DC.

U.S. Environmental Protection Agency. 2002a. Guidance for Quality Assurance Project Plans, EPA QA/G-5, EPA/240/R-02/009. Washington, DC.

U.S. Environmental Protection Agency. 2002b. Region IX Preliminary Remediation Goals (PRGs). Prepared by S.J. Smucker. San Francisco, CA.

U.S. Environmental Protection Agency. 2002c. Integrated Risk Information System (IRIS) Database, as accessed at http://www.epa.gov/iris/index.html on 16 October. 
U.S. Geological Survey. 2003. "USGS/DOE Nevada Water Use Wells.” As accessed at http://waterdata.usgs.gov/nwis/inventory/?site_no=371106116110401 on 13 November.

Western, A.W., Reynolds Electrical \& Engineering Co., Inc. 1977. Memorandum to A.E. Bicker (REECo) entitled, "Concrete Floor - Decon Facility," 28 March. Las Vegas, NV.

Wuellner, J.W., Reynolds Electrical \& Engineering Co., Inc. 1994. Memorandum to E.W. Kendall (REECo) entitled, "Inspection of Buildings 605 and 607," 23 June. Las Vegas, NV. 


\section{Appendix A.2}

\section{Project Organization}




\section{A.2 Project Organization}

The NNSA/NSO Project Manager is Janet Appenzeller-Wing, and her telephone number is (702) 295-0461.

The identification of the project Health and Safety Officer and the Quality Assurance Officer can be found in the appropriate plan. However, personnel are subject to change and it is suggested that the appropriate NNSA/NSO Project Manager be contacted for further information. The Task Manager will be identified in the FFACO Biweekly Activity Report prior to the start of activities. 


\section{Appendix A.3}

\section{Using the Visual Sampling Plan (VSP) for the Random Sample Design of CAS 06-07-01 and CAS 15-23-01}




\section{Random sampling locations for comparing a mean with a fixed threshold (nonparametric)}

\section{Summary}

This report summarizes the sampling design used, associated statistical assumptions, as well as general guidelines for conducting post-sampling data analysis. Sampling plan components presented here include how many sampling locations to choose and where within the sampling area to collect those samples. The type of medium to sample (i.e., soil, groundwater, etc.) and how to analyze the samples (in situ, fixed laboratory, etc.) are addressed in other sections of the sampling plan.

The following table summarizes the sampling design developed. A figure that shows sampling locations in the field and a table that lists sampling location coordinates are also provi ded below.

\begin{tabular}{|c|c|}
\hline \multicolumn{2}{|c|}{ SUMMARY OF SAMPLING DESIGN } \\
\hline Primary Objective of Design & Compare a site mean or median to a fixed threshold \\
\hline Type of Sampling Design & Nonparametric \\
\hline $\begin{array}{l}\text { Sample Placement (Location) } \\
\text { in the Field }\end{array}$ & Simple random sampling \\
\hline Working (Null) Hypothesis & $\begin{array}{l}\text { The median (mean) value at the site } \\
\text { exceeds the threshold }\end{array}$ \\
\hline $\begin{array}{l}\text { Formula for calculating } \\
\text { number of sampling locations }\end{array}$ & Wilcoxon signed ranks test \\
\hline Calculated total number of samples & 9 \\
\hline Number of samples on map ${ }^{a}$ & 9 \\
\hline Number of selected sample areas ${ }^{b}$ & 1 \\
\hline Specified sampling area ${ }^{\mathrm{C}}$ & $38.81 \mathrm{~m}^{2}$ \\
\hline
\end{tabular}

a This number may differ from the calculated number because of 1) grid edge effects, 2) adding judgment samples, or 3 ) selecting or unselecting sample areas.

${ }^{b}$ The number of selected sample areas is the number of colored areas on the map of the site. These sample areas contain the locations where samples are collected.

${ }^{\mathrm{c}}$ The sampling area is the total surface area of the selected colored sample areas on the map of the site.

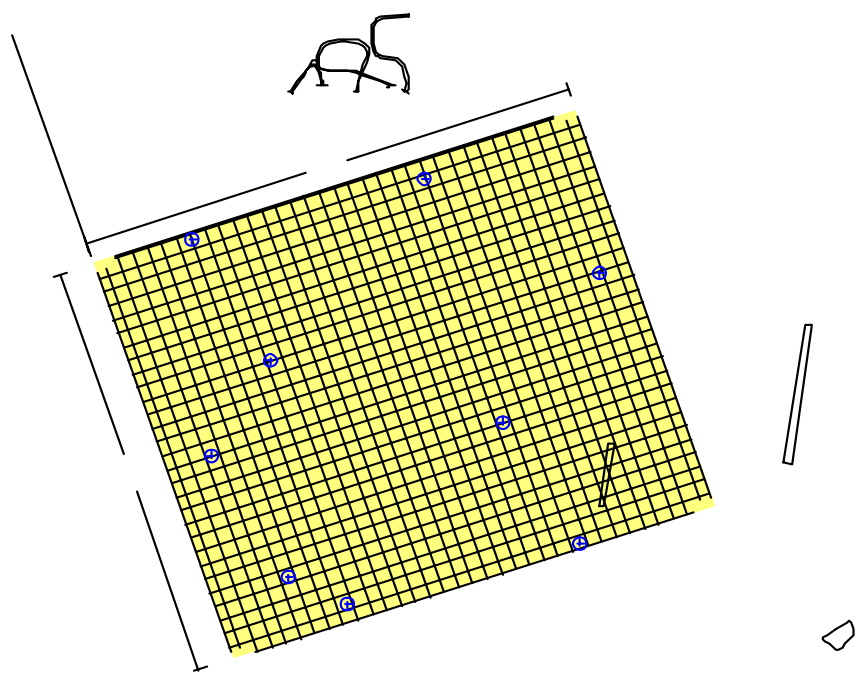




\begin{tabular}{|c|c|c|c|c|c|}
\hline \multicolumn{6}{|c|}{ Area 1} \\
\hline X Coord & Y Coord & Label & Value & Type & Historical \\
\hline $\bar{~} 585148.6268$ & 4118236.3684 & & 0 & Random & \\
\hline 585152.7348 & 4118240.5863 & & 0 & Random & \\
\hline 585147.5998 & 4118238.0555 & & 0 & Random & \\
\hline 585150.4240 & 4118241.8985 & & 0 & Random & \\
\hline 585148.3700 & 4118239.3678 & & 0 & Random & \\
\hline 585152.4780 & 4118236.8370 & & 0 & Random & \\
\hline 585147.3430 & 4118241.0549 & & 0 & Random & \\
\hline 585151.4510 & 4118238.5242 & & $\mathbf{0}$ & Random & \\
\hline 585149.3970 & 4118235.9934 & & 0 & Random & \\
\hline
\end{tabular}

\section{Primary Sampling Objective}

The primary purpose of sampling at this site is to compare a median or mean value with a fixed threshold. The working hypothesis (or 'null' hypothesis) is that the median (mean) value at the site is equal to or exceeds the threshold. The alternative hypothesis is that the median (mean) value is less than the threshold. VSP calculates the number of samples required to reject the null hypothesis in favor of the alternative one, given a selected sampling approach and inputs to the associated equation.

\section{Selected Sampling Approach}

A nonparametric random sampling approach was used to determine the number of samples and to specify sampling locations. A nonparametric formula was chosen because the conceptual model and historical information (e.g., historical data from this site or a very similar site) indicate that typical parametric assumptions may not be true.

Both parametric and non-parametric equations rely on assumptions about the population. Typically, however, non-parametric equations require fewer assumptions and allow for more uncertainty about the statistical distribution of values at the site. The trade-off is that if the parametric assumptions are valid, the required number of samples is usually less than if a non-parametric equation was used.

Locating the sample points randomly provides data that are separated by many distances, whereas systematic samples are all equidistant apart. Therefore, random sampling provides more information about the spatial structure of the potential contamination than systematic sampling does. As with systematic sampling, random sampling also provides information regarding the mean value, but there is the possibility that areas of the site will not be represented with the same frequency as if uniform grid sampling were performed.

Number of Total Samples: Calculation Equation and Inputs

The equation used to calculate the number of samples is based on a Wilcoxon Signed Ranks test. For this site, the null hypothesis is rejected in favor of the alternative one if the sample median(mean) is sufficiently smaller than the threshold. The number of samples to collect is calculated so that if the inputs to the equation are true, the calculated number of samples will cause the null hypothesis to be rejected.

The formula used to calculate the number of samples is:

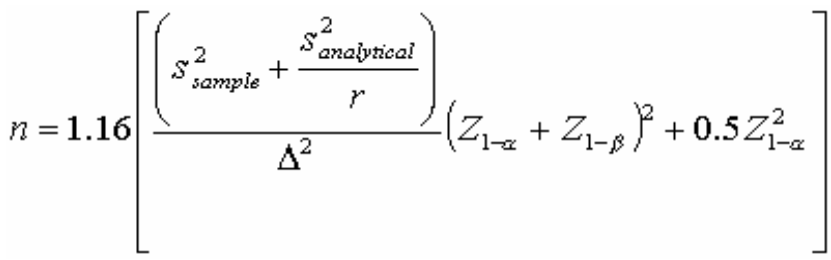

where

$n \quad$ is the number of samples, 
$S \quad$ is the estimated standard deviation of the measured values including analytical error,

$\Delta \quad$ is the width of the gray region,

$\alpha \quad$ is the acceptable probability of incorrectly concluding the site median (mean) is less than the threshold,

$\beta \quad$ is the acceptable probability of incorrectly concluding the site median (mean) exceeds the threshold,

$Z 1-\alpha \quad$ is the value of the standard normal distribution such that the proportion of the distribution less than $Z 1-\alpha$ is $1-\alpha$,

$Z 1_{-\beta} \quad$ is the value of the standard normal distribution such that the proportion of the distribution less than $Z 1-\beta$ is $1-\beta$.

The values of these inputs that result in the calculated number of sampling locations are:

\begin{tabular}{||ll||}
\hline Parameter & Value \\
\hline \hline $\mathrm{S}$ & 30 \\
$\Delta$ & 25 \\
$\alpha$ & $10 \%$ \\
$\beta$ & $20 \%$ \\
$Z 1-\alpha$ & $1.28155^{\mathrm{a}}$ \\
$Z 1-\beta$ & $0.841621^{\mathrm{b}}$ \\
\hline
\end{tabular}

a This value is automatically calculated by VSP based upon the user defined value of $\alpha$.
b This value is automatically calculated by VSP based upon the user defined value of $\beta$.

The following figure is a performance goal diagram, described in EPA's QA/G-4 guidance (EPA, 2000). It shows the probability of concluding the sample area is dirty on the vertical axis versus a range of possible true median (mean) values for the site on the horizontal axis. This graph contains all of the inputs to the number of samples equation and pictorially represents the calculation.

The red vertical line is shown at the threshold (action limit) on the horizontal axis. The width of the gray shaded area is equal to $\Delta$; the upper horizontal dashed blue line is positioned at 1- $\alpha$ on the vertical axis; the lower horizontal dashed blue line is positioned at $\beta$ on the vertical axis. The vertical green line is positioned at one standard deviation below the threshold. The shape of the red curve corresponds to the estimates of variability. The calculated number of samples results in the curve that passes through the lower bound of $\Delta$ at $\beta$ and the upper bound of $\Delta$ at 1- $\alpha$. If any of the inputs change, the number of samples that result in the correct curve changes. 


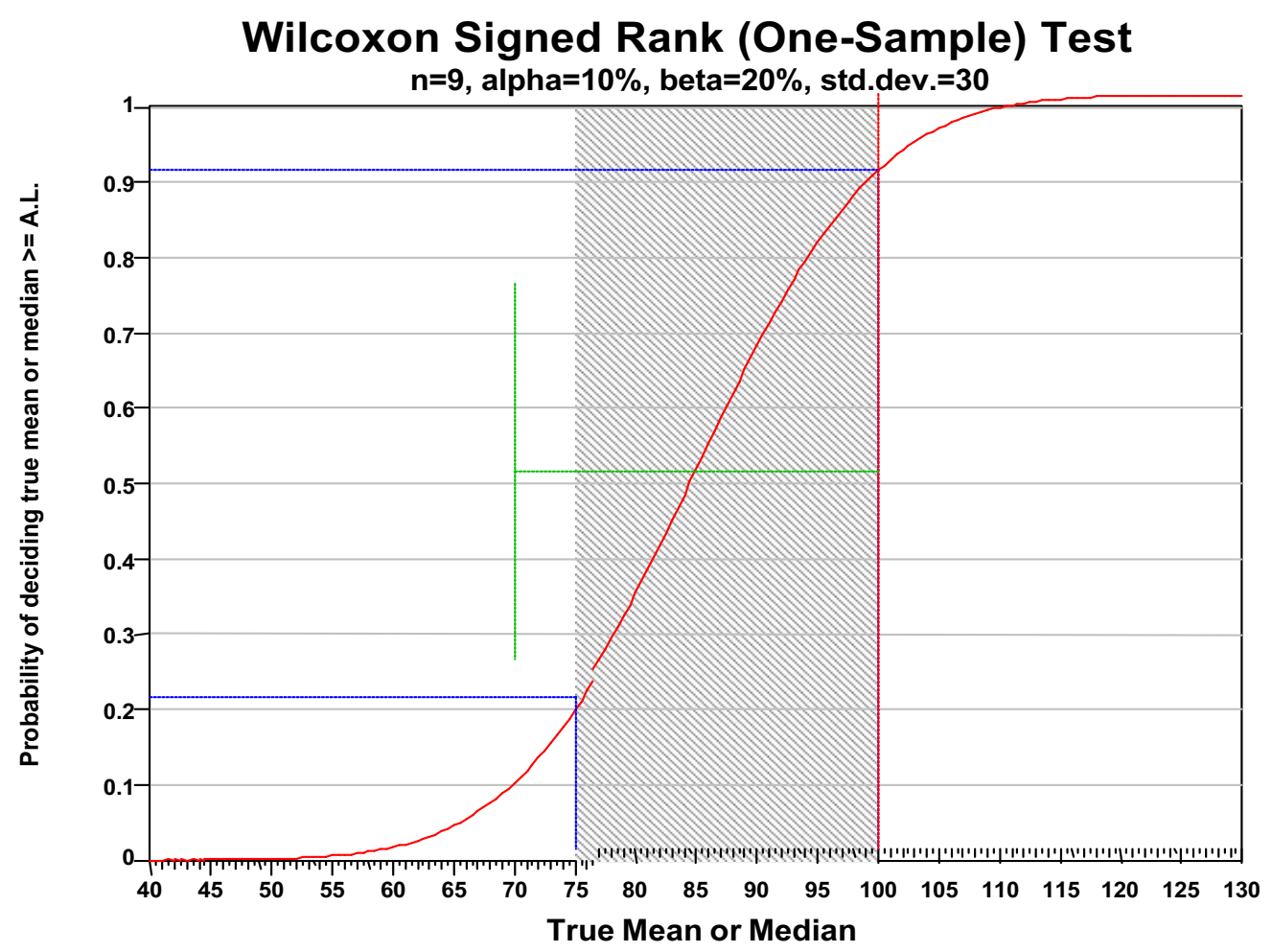

\section{Statistical Assumptions}

The assumptions associated with the formulas for computing the number of samples are:

1. The data originate from a symmetric (but not necessarily normal) population,

2. The variance estimate, $S^{2}$, is reasonable and representative of the population being sampled,

3. The population values are not spatially or temporally correlated, and

4. The sampling locations will be selected randomly.

The first three assumptions will be assessed in a post data collection analysis. The last assumption is valid because the sample locations were selected using a random process.

\section{Sensitivity Analysis}

The sensitivity of the calculation of number of samples was explored by varying S, LBGR, $\beta$ and $\alpha$ and examining the resulting changes in the number of samples. The following table shows the results of this analysis. 


\begin{tabular}{||llllllll||}
\hline \multicolumn{7}{|c||}{ Number of Samples } \\
AL=100 & & $\alpha=5$ & \multicolumn{1}{c||}{$\alpha=10$} & & $\alpha=15$ & \\
LBGR=90 & $\beta=15$ & 302 & 77 & 226 & 58 & 181 & 46 \\
& $\beta=20$ & 260 & 67 & 190 & 49 & 148 & 38 \\
& $\beta=25$ & 227 & 58 & 161 & 41 & 123 & 32 \\
LBGR $=80$ & $\beta=15$ & 77 & 21 & 58 & 15 & 46 & 12 \\
& $\beta=20$ & 67 & 18 & 49 & 13 & 38 & 10 \\
& $\beta=25$ & 58 & 16 & 41 & 11 & 32 & 9 \\
LBGR=70 & $\beta=15$ & 35 & 10 & 26 & 8 & 21 & 6 \\
& $\beta=20$ & 31 & 9 & 22 & 7 & 17 & 5 \\
& $\beta=25$ & 27 & 8 & 19 & 6 & 15 & 5 \\
\hline \hline
\end{tabular}

$S=$ Standard Deviation

LBGR $=$ Lower Bound of Gray Region (\% of Action Level)

$\beta=$ Beta $(\%)$, Probability of mistakenly concluding that $\mu>$ action level

$\alpha=$ Alpha $(\%)$, Probability of mistakenly concluding that $\mu<$ action level

$\mathrm{AL}=$ Action Level (Threshold)

\section{Recommended Data Analysis Activities}

Post data collection activities generally follow those outlined in EPA's Guidance for Data Quality Assessment (EPA, 2000). The data analysts will become familiar with the context of the problem and goals for data collection and assessment. The data will be verified and validated before being subjected to statistical or other analyses. Graphical and analytical tools will be used to verify to the extent possible the assumptions of any statistical analyses that are performed as well as to achieve a general understanding of the data. The data will be assessed to determine whether they are adequate in both quality and quantity to support the primary objective of sampling.

Because the primary objective for sampling for this site is to compare the site median (mean) value with a threshold value, the data will be assessed in this context. Assuming the data are adequate, at least one statistical test will be done to perform a comparison between the data and the threshold of interest. Results of the exploratory and quantitative assessments of the data will be reported, along with conclusions that may be supported by them.

U.S. Environmental Protection Agency. 2000. Guidance for the Data Quality Objectives Process (QA/G-4), EPA/600/R-96/055. Washington, DC. 


\section{Random sampling locations for comparing a mean with a fixed threshold (nonparametric)}

\section{Summary}

This report summarizes the sampling design used, associated statistical assumptions, as well as general guidelines for conducting post-sampling data analysis. Sampling plan components presented here include how many sampling locations to choose and where within the sampling area to collect those samples. The type of medium to sample (i.e., soil, groundwater, etc.) and how to analyze the samples (in-situ, fixed laboratory, etc.) are addressed in other sections of the sampling plan.

The following table summarizes the sampling design developed. A figure that shows sampling locations in the field and a table that lists sampling location coordinates are also provi ded below.

\begin{tabular}{|l|l|}
\hline \multicolumn{2}{|c|}{ SUMMARY OF SAMPLING DESIGN } \\
\hline Primary Objective of Design & Compare a site mean or median to a fixed threshold \\
\hline Type of Sampling Design & Nonparametric \\
\hline $\begin{array}{l}\text { Sample Placement (Location) } \\
\text { in the Field }\end{array}$ & Simple random sampling \\
\hline Working (Null) Hypothesis & $\begin{array}{l}\text { The median(mean) value at the site } \\
\text { exceeds the threshold }\end{array}$ \\
\hline $\begin{array}{l}\text { Formula for calculating } \\
\text { number of sampling locations }\end{array}$ & Wilcoxon signed ranks test \\
\hline Calculated total number of samples & 16 \\
\hline Number of samples on map ${ }^{a}$ & 16 \\
\hline Number of selected sample areas & 1 \\
\hline Specified sampling area &
\end{tabular}

a This number may differ from the calculated number because of 1) grid edge effects, 2) adding judgment samples, or 3 ) selecting or unselecting sample areas.

${ }^{b}$ The number of selected sample areas is the number of colored areas on the map of the site. These sample areas contain the locations where samples are collected.

${ }^{\mathrm{c}}$ The sampling area is the total surface area of the selected colored sample areas on the map of the site.
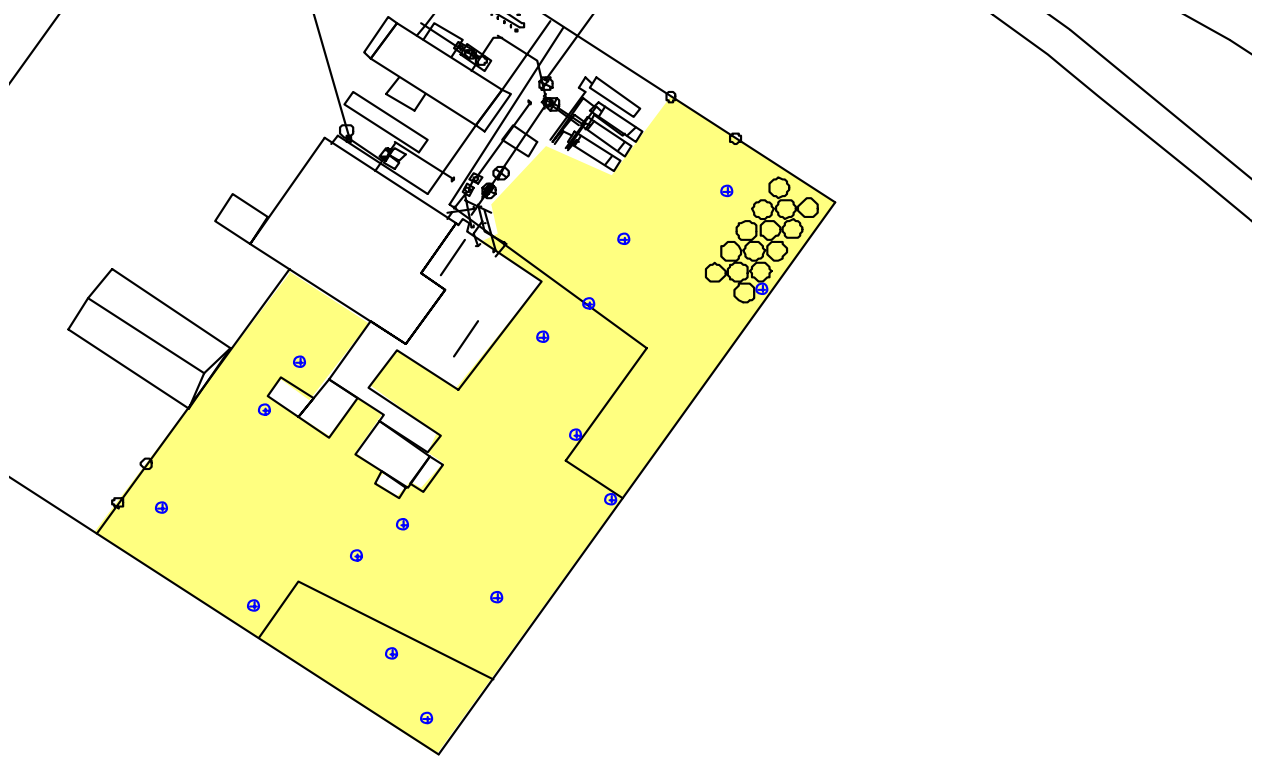


\begin{tabular}{|c|c|r|r|l|l|}
\hline \multicolumn{7}{|c|}{ Area 1 } \\
\hline X Coord & Y Coord & Label & Value & Type & Historical \\
\hline 585767.0782 & 4087921.0309 & & 0 & Random & \\
\hline 585729.9541 & 4087874.6940 & & 0 & Random & \\
\hline 585743.8757 & 4087900.4367 & & 0 & Random & \\
\hline 585762.4377 & 4087962.2193 & & 0 & Random & \\
\hline 585725.3136 & 4087915.8824 & & 0 & Random & \\
\hline 585753.1567 & 4087955.3546 & & 0 & Random & \\
\hline 585716.0326 & 4087909.0176 & & 0 & Random & \\
\hline 585790.2808 & 4087986.2459 & & 0 & Random & \\
\hline 585697.4706 & 4087939.9089 & & 0 & Random & \\
\hline 585704.4313 & 4087950.2060 & & 0 & Random & \\
\hline 585760.1175 & 4087934.7604 & & 0 & Random & \\
\hline 585722.9934 & 4087888.4234 & & 0 & Random & \\
\hline 585797.2415 & 4087965.6517 & & 0 & Random & \\
\hline 585676.5883 & 4087919.3147 & & 0 & Random & \\
\hline 585695.1503 & 4087898.7205 & & 0 & Random & \\
\hline 585769.3985 & 4087975.9488 & & 0 & Random & \\
\hline
\end{tabular}

\section{Primary Sampling Objective}

The primary purpose of sampling at this site is to compare a median or mean value with a fixed threshold. The working hypothesis (or 'null' hypothesis) is that the median(mean) value at the site is equal to or exceeds the threshold. The alternative hypothesis is that the median(mean) value is less than the threshold. VSP calculates the number of samples required to reject the null hypothesis in favor of the alternative one, given a selected sampling approach and inputs to the associated equation.

\section{Selected Sampling Approach}

A nonparametric random sampling approach was used to determine the number of samples and to specify sampling locations. A nonparametric formula was chosen because the conceptual model and historical information (e.g., historical data from this site or a very similar site) indicate that typical parametric assumptions may not be true.

Both parametric and non-parametric equations rely on assumptions about the population. Typically, however, non-parametric equations require fewer assumptions and allow for more uncertainty about the statistical distribution of values at the site. The trade-off is that if the parametric assumptions are valid, the required number of samples is usually less than if a non-parametric equation was used.

Locating the sample points randomly provides data that are separated by many distances, whereas systematic samples are all equidistant apart. Therefore, random sampling provides more information about the spatial structure of the potential contamination than systematic sampling does. As with systematic sampling, random sampling also provides information regarding the mean value, but there is the possibility that areas of the site will not be represented with the same frequency as if uniform grid sampling were performed.

\section{Number of Total Samples: Calculation Equation and Inputs}

The equation used to calculate the number of samples is based on a Wilcoxon Signed Ranks test. For this site, the null hypothesis is rejected in favor of the alternative one if the sample median(mean) is sufficiently smaller than the threshold. The number of samples to collect is calculated so that if the inputs to the equation are true, the calculated number of samples will cause the null hypothesis to be rejected. 
The formula used to calculate the number of samples is:

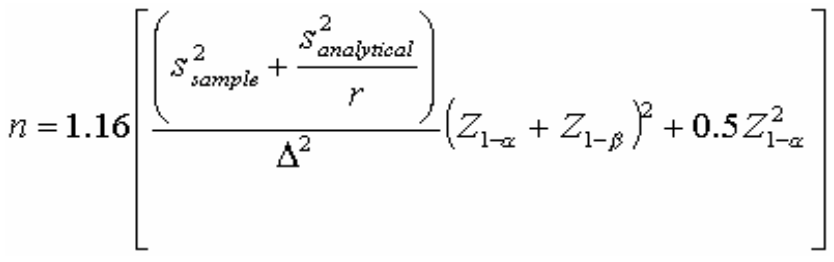

where

$n \quad$ is the number of samples,

$S \quad$ is the estimated standard deviation of the measured values including analytical error,

$\Delta \quad$ is the width of the gray region,

$\alpha \quad$ is the acceptable probability of incorrectly concluding the site median(mean) is less than the threshold,

$\beta \quad$ is the acceptable probability of incorrectly concluding the site median(mean) exceeds the threshold,

$Z_{1-\alpha} \quad$ is the value of the standard normal distribution such that the proportion of the distribution less than $Z_{1-\alpha}$ is $1-\alpha$,

$Z_{1-\beta} \quad$ is the value of the standard normal distribution such that the proportion of the distribution less than $Z_{1-\beta}$ is $1-\beta$.

The values of these inputs that result in the calculated number of sampling locations are:

\begin{tabular}{|l|l|}
\hline Parameter & Value \\
\hline$S$ & 30 \\
\hline$\Delta$ & 25 \\
\hline$\alpha$ & $5 \%$ \\
\hline$\beta$ & $10 \%$ \\
\hline$Z_{1-\alpha}$ & $1.64485^{a}$ \\
\hline$Z_{1-\beta}$ & $1.28155^{b}$ \\
\hline
\end{tabular}

a This value is automatically calculated by VSP based upon the user defined value of $\alpha$.

${ }^{\mathrm{b}}$ This value is automatically calculated by VSP based upon the user defined value of $\beta$.

The following figure is a performance goal diagram, described in EPA's QA/G-4 guidance (EPA, 2000). It shows the probability of concluding the sample area is dirty on the vertical axis versus a range of possible true median(mean) values for the site on the horizontal axis. This graph contains all of the inputs to the number of samples equation and pictorially represents the calculation.

The red vertical line is shown at the threshold (action limit) on the horizontal axis. The width of the gray shaded area is equal to $\Delta$; the upper horizontal dashed blue line is positioned at $1-\alpha$ on the vertical axis; the lower horizontal dashed blue line is positioned at $\beta$ on the vertical axis. The vertical green line is positioned at one standard deviation below the threshold. The shape of the red curve corresponds to the estimates of variability. The calculated number of samples results in the curve that passes through the lower bound of $\Delta$ at $\beta$ and the upper bound of $\Delta$ at 1- $\alpha$. If any of the inputs change, the number of samples that result in the correct curve changes. 


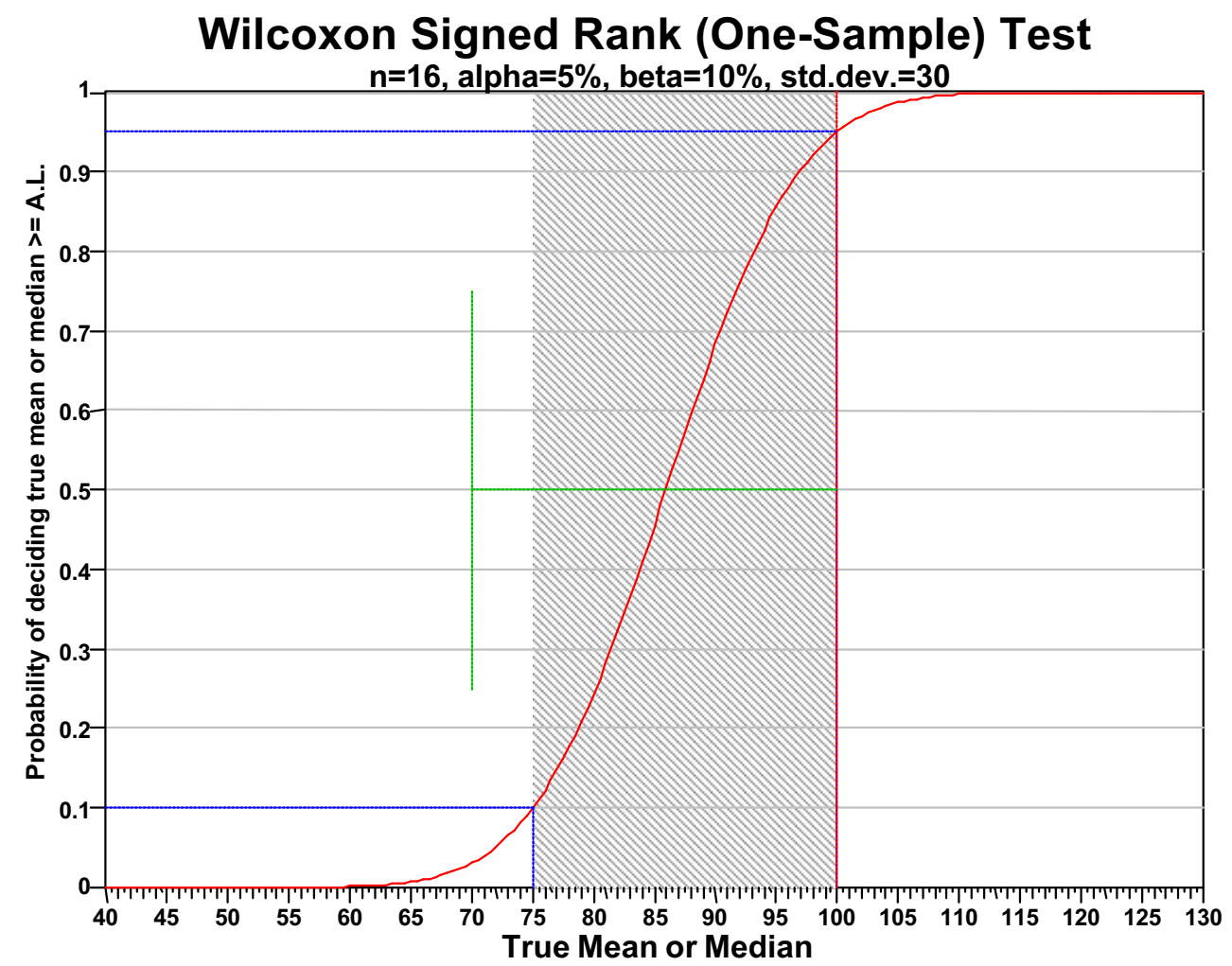

\section{Statistical Assumptions}

The assumptions associated with the formulas for computing the number of samples are:

1. The data originate from a symmetric (but not necessarily normal) population,

2. The variance estimate, $S^{2}$, is reasonable and representative of the population being sampled,

3. The population values are not spatially or temporally correlated, and

4. The sampling locations will be selected randomly.

The first three assumptions will be assessed in a post data collection analysis. The last assumption is valid because the sample locations were selected using a random process.

\section{Sensitivity Analysis}

The sensitivity of the calculation of number of samples was explored by varying S, LBGR, $\beta$ and $\alpha$ and examining the resulting changes in the number of samples. The following table shows the results of this analysis. 


\begin{tabular}{|c|l|r|r|r|r|r|r|}
\hline \multicolumn{9}{|c|}{ Number of Samples } \\
\hline \multirow{2}{*}{ AL=100 } & \multicolumn{2}{|c|}{$\mathrm{a}=\mathbf{5}$} & \multicolumn{2}{|c|}{$\mathrm{a}=\mathbf{1 0}$} & \multicolumn{2}{|c|}{$\mathrm{a}=\mathbf{1 5}$} \\
\cline { 2 - 8 } & $\mathbf{S}=\mathbf{6 0}$ & $\mathbf{S}=\mathbf{3 0}$ & $\mathbf{S}=\mathbf{6 0}$ & $\mathbf{S}=\mathbf{3 0}$ & $\mathbf{S}=\mathbf{6 0}$ & $\mathbf{S}=\mathbf{3 0}$ \\
\hline \multirow{3}{*}{ LBGR=90 } & $\mathrm{b}=\mathbf{5}$ & 454 & 115 & 359 & 91 & 301 & 76 \\
\cline { 2 - 9 } & $\mathrm{b}=\mathbf{1 0}$ & 360 & 91 & 276 & 70 & 226 & 57 \\
\cline { 2 - 9 } & $\mathrm{b}=\mathbf{1 5}$ & 302 & 77 & 226 & 58 & 181 & 46 \\
\hline \multirow{3}{*}{ LBGR=80 } & $\mathrm{b}=\mathbf{5}$ & 115 & 30 & 91 & 24 & 76 & 20 \\
\cline { 2 - 9 } & $\mathrm{b}=\mathbf{1 0}$ & 91 & 24 & 70 & 19 & 57 & 15 \\
\cline { 2 - 9 } & $\mathrm{b}=\mathbf{1 5}$ & 77 & 21 & 58 & 15 & 46 & 12 \\
\hline \multirow{3}{*}{ LBGR=70 } & $\mathrm{b}=\mathbf{5}$ & 52 & 15 & 41 & 11 & 34 & 9 \\
\cline { 2 - 8 } & $\mathrm{b}=\mathbf{1 0}$ & 42 & 12 & 32 & 9 & 26 & 7 \\
\cline { 2 - 9 } & $\mathrm{b}=\mathbf{1 5}$ & 35 & 10 & 26 & 8 & 21 & 6 \\
\hline
\end{tabular}

$S=$ Standard Deviation

LBGR = Lower Bound of Gray Region (\% of Action Level)

$\beta=$ Beta (\%), Probability of mistakenly concluding that $\mu>$ action level

$\alpha=$ Alpha (\%), Probability of mistakenly concluding that $\mu<$ action level

$\mathrm{AL}=$ Action Level (Threshold)

\section{Recommended Data Analysis Activities}

Post data collection activities generally follow those outlined in EPA's Guidance for Data Quality Assessment (EPA, 2000). The data analysts will become familiar with the context of the problem and goals for data collection and assessment. The data will be verified and validated before being subjected to statistical or other analyses. Graphical and analytical tools will be used to verify to the extent possible the assumptions of any statistical analyses that are performed as well as to achieve a general understanding of the data. The data will be assessed to determine whether they are adequate in both quality and quantity to support the primary objective of sampling.

Because the primary objective for sampling for this site is to compare the site median(mean) value with a threshold value, the data will be assessed in this context. Assuming the data are adequate, at least one statistical test will be done to perform a comparison between the data and the threshold of interest. Results of the exploratory and quantitative assessments of the data will be reported, along with conclusions that may be supported by them.

U.S. Environmental Protection Agency. 2000. Guidance for the Data Quality Objectives Process (QA/G-4), EPA/600/R-96/055. Washington, DC. 
Date: $05 / 03 / 2004$

Page A-89 of A-91

Appendix A.4

\section{Response to NDEP Comments}




\section{NEVADA ENVIRONMENTAL RESTORATION PROJECT DOCUMENT REVIEW SHEET}

\begin{tabular}{|c|c|c|c|c|c|}
\hline \multicolumn{4}{|c|}{$\begin{array}{l}\text { 1. Document Title/Number: Draft Corrective Action Investigation Plan for Corrective Action Unit 543: } \\
\text { Liquid Disposal Units, Nevada Test Site, Nevada }\end{array}$} & \multicolumn{2}{|l|}{ 2. Document Date: March 2004} \\
\hline \multicolumn{4}{|c|}{ 3. Revision Number: 0} & \multicolumn{2}{|c|}{ 4. Originator/Organization: Stoller-Navarro } \\
\hline \multicolumn{4}{|c|}{ 5. Responsible NNSA/NV ERP Project Mgr.: Janet Appenzeller-Wing } & \multicolumn{2}{|l|}{ 6. Date Comments Due: April 12, 2004} \\
\hline \multicolumn{6}{|c|}{ 7. Review Criteria: Full } \\
\hline \multicolumn{4}{|c|}{ 8. Reviewer/Organization/Phone No.: Donald R. Elle, NDEP, 486-2874 } & \multicolumn{2}{|l|}{ 9. Reviewer's Signature: } \\
\hline $\begin{array}{l}\text { 10. Comment } \\
\text { Number/ } \\
\text { Location }\end{array}$ & 11. Type* & 12. Comment & \multicolumn{2}{|c|}{ 13. Comment Response } & 14. Accept \\
\hline $\begin{array}{l}\text { 1) Section } 5.3 .2 \\
\text { Hazard Waste and } \\
\text { Section } 3.2 \\
\text { Contaminants of } \\
\text { Potential Concern }\end{array}$ & & $\begin{array}{l}\text { Although prior testing has not identified "listed" wastes, prior } \\
\text { knowledge indicates that these wastes might be present. A } \\
\text { thorough discussion of the reasons that listed wastes are not } \\
\text { believed to be present or allowance for testing for listed wastes must } \\
\text { be included in the final document. }\end{array}$ & \multicolumn{2}{|c|}{$\begin{array}{l}\text { The following sentence has been added to the end of } \\
\text { Section 5.3.2: Direct sampling of waste or request for TCLP } \\
\text { analysis may be requested by the Waste Management Lead } \\
\text { or Site Supervisor if necessary. } \\
\text { The following sentence has been added to the end of } \\
\text { Section 3.2: Some of the chemicals used at CAU } 543 \text { sites } \\
\text { are potential RCRA contaminants. The historical literature } \\
\text { for the CASs has been thoroughly reviewed. When } \\
\text { applicable, the sample locations, source of data, data date, } \\
\text { constituents, site processes, and activities at each CAS } \\
\text { were reviewed. There is insufficient process knowledge to } \\
\text { consider any chemicals "RCRA listed" at the CAU } 543 \text { sites } \\
\text { (Franky, 2003). If analytical results indicate the presence of } \\
\text { RCRA contaminants, they will be evaluated as potential } \\
\text { "characteristic" wastes. Total results will be calculated as } \\
\text { theoretical TCLP values, if necessary TCLP analysis will be } \\
\text { requested for samples to ensure full RCRA characterization } \\
\text { (CFR, 2003a) }\end{array}$} & Yes \\
\hline $\begin{array}{l}\text { 2) Section } 4.2 .4 .1 \\
\text { CAS 06-07-01 } \\
\text { Decon Pad and } \\
\text { Section } 4.2 .4 .2 \\
\text { Area } 15 \text { EPA Farm }\end{array}$ & & $\begin{array}{l}\text { During the DQO meeting, it was acknowledged that pipes would be } \\
\text { grouted upon completion of field testing. Acknowledgment of this } \\
\text { standard practice should be made within these sections. }\end{array}$ & \multicolumn{2}{|c|}{$\begin{array}{l}\text { The following sentence has been added to end of the sixth } \\
\text { paragraph in Section } 4.2 .2 \text { which discusses the inspection of } \\
\text { collection and distribution systems: "Sections of piping that } \\
\text { are breached to gain access for inspection and/or sampling } \\
\text { will be grouted upon completion of those activities." }\end{array}$} & Yes \\
\hline
\end{tabular}




\section{NEVADA ENVIRONMENTAL RESTORATION PROJECT} DOCUMENT REVIEW SHEET

\begin{tabular}{|c|c|c|c|c|}
\hline $\begin{array}{l}\text { 10. Comment } \\
\text { Number/ } \\
\text { Location }\end{array}$ & 11. Type* & 12. Comment & 13. Comment Response & 14. Accept \\
\hline $\begin{array}{l}\text { 3) Section 3.4 Data } \\
\text { Quality Objectives } \\
\text { Process } \\
\text { Discussion, } \\
\text { 1st Paragraph } \\
\text { Page } 39\end{array}$ & & $\begin{array}{l}\text { It should be noted that viable corrective actions include clean } \\
\text { closure in addition to closure-in-place and no further action. }\end{array}$ & $\begin{array}{l}\text { The text has been modified to include clean closure as a } \\
\text { viable corrective action. }\end{array}$ & Yes \\
\hline $\begin{array}{l}\text { 4) Section } 3.3 \\
\text { Preliminary Action } \\
\text { Levels, 2nd and } \\
\text { 4th Paragraphs } \\
\text { After the Bullet } \\
\text { Page } 38\end{array}$ & & $\begin{array}{l}\text { These paragraphs state that Section A.1.2.3 of Appendix A.1 } \\
\text { contains a discussion of future land uses. The appendix does not } \\
\text { contain that discussion. Section } 3.1 .1 \text { of the main body of the report } \\
\text { discusses future land use. }\end{array}$ & $\begin{array}{l}\text { The text has been modified to reference Section 3.1.1 } \\
\text { instead of referencing Appendix A.1. }\end{array}$ & Yes \\
\hline $\begin{array}{l}\text { 5) Section } 3.1 .7 \\
\text { Additional } \\
\text { Information, 1st } \\
\text { Paragraph } \\
\text { Page } 35\end{array}$ & & $\begin{array}{l}\text { A statement in this paragraph refers to Section } 2.1 .1 \text { through } \\
\text { Section } 2.1 .3 \text { and then acknowledges that Section } 2.1 .3 \text { does not } \\
\text { exist. The correction of this item should change the reference to } \\
\text { Section 2.1.1 through Section 2.1.2. }\end{array}$ & $\begin{array}{l}\text { The text has been modified to reference Section } 2.1 .1 \\
\text { through 2.1.2. The text referencing Section } 2.1 .3 \text { has been } \\
\text { deleted. }\end{array}$ & Yes \\
\hline $\begin{array}{l}\text { 6) Section } 2.2 .2 \\
\text { The EPA Farm } \\
\text { 1st Paragraph, } \\
\text { Page } 16\end{array}$ & & $\begin{array}{l}\text { A minor typographical error was noted in the fourth sentence. The } \\
\text { word "diary" should be changed to "dairy". }\end{array}$ & The word has been changed to "dairy." & Yes \\
\hline
\end{tabular}

${ }^{a}$ Comment Types: $M=$ Mandatory, $S=$ Suggested

Return Document Review Sheets to NNSA/NV Environmental Restoration Division, Attn: QAC, M/S 505. 


\section{Distribution}

* Provide a copy in distribution of Rev. 0 and subsequent revisions, if applicable. Copies of only the NDEP-approved document will be distributed to others.

\section{$\underline{\text { Copies }}$}

Terre Maize

1 (Controlled)*

State of Nevada

Bureau of Federal Facilities

Division of Environmental Protection

1771 E. Flamingo Rd., Suite 121-A

Las Vegas, NV 89119

State of Nevada

1 (Controlled)*

Bureau of Federal Facilities

Division of Environmental Protection

333 W. Nye Lane, Room 138

Carson City, NV 89706-0851

D.R. Elle

1 (Controlled)*

State of Nevada

Bureau of Federal Facilities

Division of Environmental Protection

1771 E. Flamingo Rd., Suite 121-A

Las Vegas, NV 89119

Shirley Doty

Environmental Restoration Division

1 (Controlled)*

U.S. Department of Energy

National Nuclear Security Administration

Nevada Site Office

P.O. Box 98518, M/S 505

Las Vegas, NV 89193-8518

Janet Appenzeller-Wing

Environmental Restoration Division

1 (Uncontrolled)*

U.S. Department of Energy

National Nuclear Security Administration

Nevada Site Office

P.O. Box 98518, M/S 505

Las Vegas, NV 89193-8518 


\section{$\underline{\text { Copies }}$}

Kevin Cabble

Environmental Restoration Division

1 (Uncontrolled)*

U.S. Department of Energy

National Nuclear Security Administration

Nevada Site Office

P.O. Box 98518, M/S 505

Las Vegas, NV 89193-8518

Sabine Curtis

Environmental Restoration Division

1 (Uncontrolled)*

U.S. Department of Energy

National Nuclear Security Administration

Nevada Site Office

P.O. Box 98518, M/S 505

Las Vegas, NV 89193-8518

David Swanson

Assistant Project Administrator

1 (Uncontrolled)*

Nye County

Department of Natural Resources \& Federal Facilities

1210 E. Basin Road, Suite \#6

Pahrump, NV 89060

Public Reading Facility Coordinator

1 (Controlled)

Stoller-Navarro Joint Venture

7710 W. Cheyenne, Bldg. 3

Las Vegas, NV 89129

U.S. Department of Energy

1 (Uncontrolled, electronic copy)

National Nuclear Security Administration

Nevada Site Office

Technical Library

P.O. Box 98518, M/S 505

Las Vegas, NV 89193-8518

U.S. Department of Energy

Office of Scientific and Technical Information

1 (Uncontrolled, electronic copy)

P.O. Box 62

Oak Ridge, TN 37831-0062 


\section{$\underline{\text { Copies }}$}

Southern Nevada Public Reading Facility

1 (Controlled)

c/o Nuclear Testing Archive

1 (Uncontrolled)

P.O. Box 98521, M/S 400

Las Vegas, NV 89193-8521

Manager, Northern Nevada FFACO

1 (Uncontrolled)

Public Reading Facility

c/o Nevada State Library \& Archives

Carson City, NV 89701-4285

Jeffrey L. Smith

1 (Uncontrolled)*

Bechtel Nevada

P.O. Box 98521, M/S NTS306

Las Vegas, NV 89193-8521

Glenn Richardson

1 (Uncontrolled)*

Bechtel Nevada

P.O. Box 98521, M/S NTS306

Las Vegas, NV 89193-8521

Brian Hoenes

1 (Uncontrolled)*

Stoller-Navarro Joint Venture

7710 W. Cheyenne, Bldg. 3

Las Vegas, NV 89129

Alfred Wickline

1 (Uncontrolled)*

Stoller-Navarro Joint Venture

7710 W. Cheyenne, Bldg. 3

Las Vegas, NV 89129

Dawn Arnold

1 (Uncontrolled)*

Stoller-Navarro Joint Venture

7710 W. Cheyenne, Bldg. 3

Las Vegas, NV 89129

Central Files

1 (Uncontrolled)*

Stoller-Navarro Joint Venture

7710 W. Cheyenne, Bldg. 3

Las Vegas, NV 89129 